UNIVERSIDADE DE BRASÍLIA

INSTITUTO DE CIENCIAS HUMANAS - DEPARTAMENTO DE HISTÓRIA

PROGRAMA DE PÓS-GRADUAÇÃO EM HISTÓRIA

CAROLINA SOARES SOUSA

"PARA QUE O BRASIL CONTINUE": MEMÓRIA E HISTÓRIA DE UM GRUPO DERROTADO NA POLÍTICA NACIONAL (1933-1945)

BRASÍLIA, 2016 
UNIVERSIDADE DE BRASÍLIA

INSTITUTO DE CIÊNCIAS HUMANAS - DEPARTAMENTO DE HISTÓRIA

PROGRAMA DE PÓS-GRADUAÇÃO EM HISTÓRIA

CAROLINA SOARES SOUSA

“PARA QUE O BRASIL CONTINUE”: MEMÓRIA E HISTÓRIA DE UM GRUPO DERROTADO NA POLÍTICA NACIONAL (1933-1945)

Tese apresentada ao Programa de Pós-Graduação em História, da Universidade de Brasília, como requisito obrigatório para obtenção do Título de Doutor em História (Área de Concentração: Sociedade, Cultura e Política; Linha de Pesquisa: História Cultural, Memórias e Identidades).

Orientador (a): Profa. Dra. Diva do Couto Gontijo Muniz

BRASÍLIA, 2016 
CAROLINA SOARES SOUSA

\title{
“PARA QUE O BRASIL CONTINUE”: MEMÓRIA E HISTÓRIA DE UM GRUPO DERROTADO NA POLÍTICA NACIONAL (1933-1945)
}

Tese apresentada ao Programa de Pós-Graduação em História, da Universidade de Brasília, como requisito obrigatório para a obtenção do Título de Doutor em História.

\section{BANCA EXAMINADORA}

\author{
Profa. Dra. Diva do Couto Gontijo Muniz - UnB \\ Presidente da Banca
}

Prof. Dr. Noé Freire Sandes - UFG

Examinador

Profa. Dra. Lucilia de Almeida Neves Delgado - ANPUH

Examinadora

Prof. Dra. Eloísa Pereira Barroso - UnB

Examinadora

Profa. Dra. Albene Miriam Menezes Klemi - UnB

Examinadora

Profa. Dra. Fabiane Costa Oliveira - IFG

Suplente

Brasília, 4 de agosto de 2016. 


\section{AGRADECIMENTOS}

À minha orientadora, Diva do Couto Gontijo Muniz, agradeço pela seriedade e paciência com que conduziu a relação de orientação. Como the disse, ela foi, indiscutivelmente, a orientadora mais dedicada.

Foi um motivo de grande satisfação poder contar com a leitura criteriosa dos professores Noé Freire Sandes e Albene Miriam Ferreira, quando do exame de qualificação. A eles envio meus sinceros agradecimentos. Com o professor Noé, minha dívida é maior. Esta tese ainda é fruto do trabalho que iniciamos durante minha graduação, creio que agora encerramos uma etapa. Agradeço por ter acompanhando minha formação acadêmica, sempre me incentivando e não me deixando desistir.

À professora Lucília Neves de Almeida Delgado, meus sinceros agradecimentos por ter gentilmente aceito participar da banca examinadora da tese.

À professora e amiga Fabiane Oliveira, por tudo que me ensinou durante esses quase dez anos de amizade sincera. Esta tese também é resultado das inúmeras conversas que tivemos entre Goiânia e Brasília.

À amiga Allice Silveira, pela amizade e torcida de sempre. Allice, mesmo atarefada com o Doutorado Sanduíche, aceitou de pronto a incumbência de traduzir o resumo para o inglês, realizando-a com muita competência, como tudo que ela se propõe a fazer. Que meu abraço apertado chegue aí, em Paris, querida. Saudade!

Aos amigos queridos Ivan Vieira, Idila de Roure, Thaisy Sosnoski, Gabriela Carmona, Nathália Mariano, Rafaela Oliveira, Mariana Sales, Isabella Pimentel, Isabella Bretas, Tálita Christina, Alexandre de Paula Meirelles, Ludmilla Sapiência, João Leonel, Fernanda. Alguns de vocês já me acompanham há muito tempo, outros são amizades recentes, gratas surpresas. Entretanto, com todos vocês, nos últimos tempos, dividi as angustias de enfrentar a vida adulta e das escolhas que precisamos fazer. Vamos juntos!

Juliano Mendes, Claudia Caetano e à bela Alice, família que me encanta, agradeço imensamente pela amizade e torcida. 
Às amigas Julia Furia e Fabiana Macena, quero registrar que ganhar a amizade de vocês foi uma das gratas surpresas que a Universidade de Brasília me proporcionou. Fabiana, sempre prestativa, e Julia, sempre hospitaleira.

Ao Wagner Filho, pelas acolhidas na cidade de São Paulo quando de minhas pesquisas realizadas na Universidade de São Paulo e no Arquivo Estadual.

Aos meus Pais e irmãos, agradeço pela tolerância. À pequena Luisinha, nossa Pituquinha, que alegra nossa casa.

Aos funcionários do Centro de Documentação Alexandre Eulálio - CEDAE, Flávia Leão, Cristiano Diniz e Cleonice Moreira. O cuidado e compromisso com o que eles cuidam daquele arquivo é admirável. Fui muito bem recebida.

Aos funcionários do Programa de Pós-Graduação em História da UnB, Jorge Vilella e Rodolfo Nunes Jr., sempre gentis e prestativos.

Ao CNPq, agradeço o apoio financeiro, com o qual a pesquisa evoluiu. 
Ah, quem escreverá a história do que poderia ter sido?

Será essa, se alguém a escrever,

A verdadeira história da humanidade

\section{$[\cdots]$}

O irreparável do meu passado - esse é o cadáver!

Se em certa altura

Tivesse voltado para a esquerda em vez de para a direita;

Se em certo momento

Tivesse dito sim em vez de não, ou não em vez de sim;

Se em certa conversa

Tivesse tido as frases que só agora, no meio-sono, elaboro-

Se tudo tivesse sido assim,

Seria outro hoje, e talvez o universo inteiro

Seria insensivelmente levado a ser outro também.

(Fernando Pessoa)

Belchior cantou que o passado é uma roupa que não nos serve mais. Pode ser. Também pode ser um tecido cortado, costurado, recortado, recosturado, infinitamente... Em permanente construção. Tão incerto quanto o futuro.

(Humberto Gessinger) 


\section{RESUMO}

Esta tese tem como objetivo o estudo da atuação de Armando de Salles Oliveira e Paulo Alfeu Junqueira Duarte dentro do grupo político armandista. Priorizamos seus protagonismos no jogo político regional e nacional do período de 1933 a 1945. Como se trata de um grupo derrotado, a memória construída acerca dessa experiência ignorou sua especificidade e incorporou-a no discurso homogeneizador e continuísta que conflui e deságua na "Era Vargas". Com efeito, na historiografia e na memória social, a experiência política de Vargas entre 1930 e 1945 é representada como uma continuidade, um bloco coeso, que desconhece e constrói um silencio sobre os conflitos entre as elites e o governo federal e até mesmo intra elites. Desnaturalizar a leitura de continuidade naquele período é imperativo para compreender a atuação do grupo político armandista. É em São Paulo, com o pensamento e ação deste grupo, entre 1933-1945, que será desenvolvida com maior expressividade uma cultura de oposição ao varguismo.

Palavras-chave: memória, história, grupo político armandista 


\begin{abstract}
This thesis aims to study the role of Armando de Salles Oliveira and Paulo Alpheus Junqueira Duarte within the political group Armandista and it prioritizes its protagonism in the regional and national political game of the period from 1933 to 1945. As the Armandista group is a defeated group, the memory built on this experience has ignored their specificity and incorporated it in the homogenizing and continuist discourse that converges and flows into the "Era Vargas". As a matter of fact, Vargas' political experience between 1930 and 1945 in the historiographical work and in social memory is represented as a continuous process, a cohesive block that ignores and builds a silence on the conflict between the elites and the federal government and even amongst elites. It is imperative to denaturalize the reading of continuity of that period so as to understand the performance of the armandista political group. It is in São Paulo, with the thought and action of this group, that an oppositional culture to varguismo will be developed with greater expressivity during the period of 1933-1945.
\end{abstract}

Keywords: memory, history, political group armandista 


\section{SUMÁRIO}

INTRODUÇÃO 10

CAPÍTULO I - ARMANDO DE SALLES OLIVEIRA E SEU GRUPO POLÍTICO: APROXIMAÇÕES E DISTANCIAMENTOS DO GOVERNO VARGAS . .24

1.1. A indicação de Armando de Salles Oliveira para interventoria de São Paulo: aproximações com Getúlio Vargas e o projeto político de

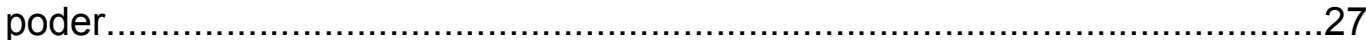

1.1.1. Da interventoria ao governo constitucional. Os três pilares do projeto político armandista colocados em prática. São Paulo deve ser vitrine para o

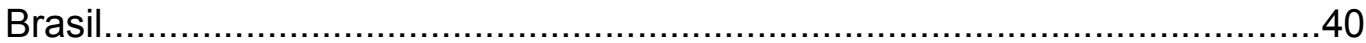

1.1.2. A Universidade de São Paulo e a Prefeitura de Fábio Prado........................46

1.2. A nova "depuração das elites".................................................................51

1.2.1. 1935: o tema dos "extremismos" redireciona o espectro do campo político..........................................................................................

1.3. "Achegas para uma história não escrita". A candidatura de Armando de Salles Oliveira e a defesa da Constituição............................................................59

1.3.1. O debate sucessório 63

CAPÍTULO II - "PARA QUE O BRASIL CONTINUE". A CAMPANHA PRESIDENCIAL E O GOLPE DE NOVEMBRO DE 1937.....................................76

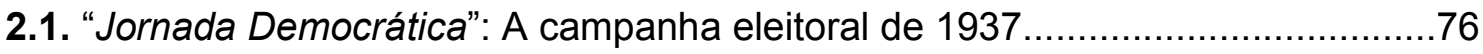

2.2. A União Democrática Brasileira e sua importância na articulação da campanha

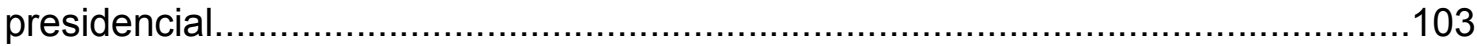

2.3. Nem do norte, nem do sul: a hora é do Brasil...........................................107

2.4. O golpe se aproxima. A ação política do grupo armandista............................112

CAPÍTULO III - PAULO DUARTE, MEMÓRIA, ARQUIVO E RESSENTIMENTO

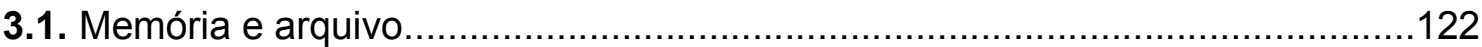

3.2. O golpe de novembro de 1937 nas memórias de Paulo Duarte.......................134

3.3. "Prisão, exílio e luta": mais que fantasmas; exilados propondo ações, articulando

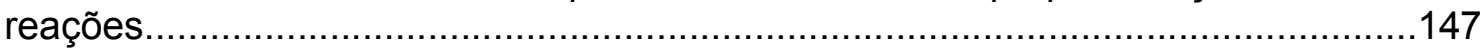

3.4. A aventura de Paulo Duarte, clandestino no Brasil.......................................169

3.5. Paulo Duarte, memória e ressentimento......................................................175

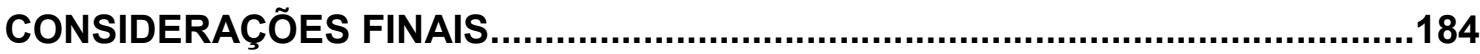

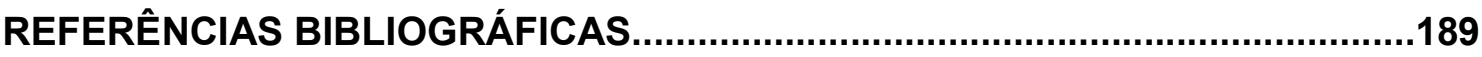




\section{INTRODUÇÃO}

A historiografia ${ }^{1}$ que enfoca o período de 1930 a 1945 como bloco coeso tratou o golpe do Estado Novo, ocorrido em 1937, como conclusão lógica da Revolução de 1930. Sob tal perspectiva, foi constituída narrativa hegemônica em que Vargas ganhou papel de centralidade. As elites políticas também surgiram como atores históricos, mas em menor proporção, uma vez que a ênfase foi dada ao protagonismo de Vargas como estrategista político, o que acabou por relativizar a atuação das elites. A visão de que a Revolução de 1930 se consumou somente com o golpe de 1937 foi também a visão oficial dos próceres do Estado Novo, entre eles políticos, intelectuais e militares, que buscaram legitimar o regime com tal discurso. O Estado Novo, instaurado em 1937, teria vindo para consolidar as mudanças projetadas durante a Revolução de 1930. Nesse sentido, a ideia de uma linha de continuidade entre1930 e 1937 era perfeita para aqueles que instauraram o Estado Novo (CAMARGO, 1989).

É em direção contrária que fomos instadas a retomar o diálogo entre as elites políticas paulistas e o governo central. Nessa direção, encontramos uma dimensão ainda pouco considerada pela historiografia brasileira, justamente a das articulações operadas e dos protagonismos ocorridos por elites e suas relações com o governo federal; ou seja, a que contempla a participação efetiva desse grupo paulista no jogo político republicano pós-1930. Consideramos, especificamente, a atuação de Armando de Salles Oliveira e o projeto político pensado por ele e seu grupo, com pretensões nacionais, sob a hegemonia de São Paulo.

\footnotetext{
${ }^{1}$ No período pós-1964 foi construída uma historiografia que priorizou organizar uma reflexão sobre o papel do Estado, evidenciando este como detentor do lugar de sujeito histórico. Dentre os autores que colaboraram com tal historiografia estão Francisco Weffort, Boris Fausto, Octavio Ianni, Luis Werneck Vianna, Fernando Henrique Cardoso, entre outros. Tal perspectiva excluiu a participação de outros atores históricos. Para um balanço historiográfico sobre tal historiografia, a revolução de 1930 e o período entre 1930 e 1937, consultar as seguintes obras: BORGES, Vavy Pacheco. Anos 1930 e política. História e Historiografia. In: FREITAS, Marcos César. Historiografia brasileira em perspectiva. São Paulo: Contexto, 1998; DECCA, Edgar de. O silêncio dos vencidos. São Paulo: Ed. Brasiliense, 2004; VESENTINI, Carlos Alberto. A teia do fato (uma proposta de estudo sobre a memória histórica). São Paulo: Ed. Hucitec, História Social, USP, 1997. Esses trabalhos contribuíram para diferentes formações e interpretações de uma memória histórica da revolução outubrista.
} 
O pensamento político de Armando de Salles Oliveira explicita-se nos discursos que marcaram sua passagem pela interventoria de São Paulo e durante as duas campanhas eleitorais que enfrentou: uma para governo, em 1934, e outra para presidente, entre 1936 e 1937. Pensamento, esse, que diferia de muitos intelectuais paulistas da época, dentre estes, Oliveira Viana, que via, contrariamente a Armando de Salles Oliveira e seu grupo político, as resoluções dos problemas brasileiros na organização das classes econômicas e não de partidos políticos. Diferente também das ideias de políticos como Agamenon Magalhães, Francisco Campos, Azevedo Amaral, Miguel Reale e Plínio Salgado, que defendiam uma proposta de Estado autoritário-corporativo. Tais ideias encontravam-se difundidas no campo intelectual da época (CAMARGO, 1989) e eram nesse sentido distanciadas do pensamento de Armando de Salles Oliveira, para quem a resolução dos problemas do país dependia diretamente do fortalecimento dos partidos políticos. Seus pensamentos e ações foram marcados pelo desafio e propósito de organizar politicamente o país, pela mediação dos partidos políticos. Defendia que o cerne do problema brasileiro estava não na organização das classes econômicas, mas sim de um partido nacional, ferreamente disciplinado e comprometido com o projeto de mudanças no país. Nessa direção, afirmam-se os contornos de uma cultura política que mobilizava a atuação de um partido de âmbito nacional, como linguagem básica de oposição ao varguismo, que ainda tem merecido pouca atenção dos historiadores.

Os itinerários políticos de Armando de Salles Oliveira e de seu grupo político, derrotados com golpe de novembro de 1937, foram marcados fundamentalmente por quatro momentos do jogo político nacional. Os três primeiros momentos são: de apoio a Getúlio Vargas, durante a Revolução de 1930; de oposição a Getúlio Vargas, entre 1930 e 1932 - com a Revolução Constitucionalista; e, novamente, apoio ao governo Vargas com a ascensão de Armando de Salles Oliveira à interventoria de São Paulo, de 1933-1936. Entretanto, o quarto momento da relação entre as elites políticas paulistas e Getúlio Vargas será marcado por novo distanciamento, traduzido na declarada oposição a Vargas, com a candidatura de Armando de Salles Oliveira à presidência da República para o pleito que ocorreria em 3 de janeiro de 1938, contrariamente às pretensões de Vargas. Trata-se de posição de confronto que tem como desfecho o golpe de 10 de novembro de 1937 e 
que se estende por todo o exílio de Armando de Salles Oliveira. Situação que perdurou até abril de 1945, quando então o político paulista retorna ao Brasil, doente, sem condições físicas para o protagonismo no jogo político do pós-guerra.

Sobre os passos que levaram ao Estado Novo é necessário considerar que, quando não se fez silêncio sobre o pensamento e estratégias políticas de Armando de Salles Oliveira e do Partido Constitucionalista, foram tratados como expressões de forças regressistas. Nesta representação, eles compreendiam o grupo político que, caso conseguissem ascender à presidência com a possível vitória da União Democrática Brasileira, pretendiam justamente recuperar para si o poder perdido pelo Partido Republicano Paulista em 1930 (OLIVEIROS, 2007).

No presente estudo orientamo-nos pela tese de que a rearticulação de São Paulo como força propulsora de um projeto nacional contribuiu para mobilizar o governo constitucional em direção ao golpe que fundou o Estado Novo. Claro que entendemos que tal contribuição não exclui outras forças envolvidas nas disputas políticas do período, dentre elas, a capacidade de Vargas em cooptar forças políticas para o seu lado, a ação dos militares e dos integralistas e a própria conjuntura de oposição fortemente travada pelos comunistas e por Flores da Cunha e seu grupo naquele momento. Mas não podemos desconsiderar que a atuação do grupo político paulista foi peça importante do jogo político da década de 1930. Nesse sentido, nosso propósito foi o de analisar a campanha eleitoral de Armando de Salles Oliveira à Presidência da República, colocando em evidência o fortalecimento do grupo armandista e seu projeto de ascensão à presidência da República, via eleições de janeiro de 1938. Defendemos que o crescimento do Partido Constitucionalista ameaçou a situação de estabilidade na composição das forças políticas, expressa na acirrada luta política com o governo federal. Nosso entendimento é o de que a candidatura de Armando de Salles Oliveira à presidência ameaçava as intenções continuístas de Vargas e acenava com a possibilidade de São Paulo reaver sua posição hegemônica no cenário político nacional. ${ }^{2}$

\footnotetext{
2 Joseph Love analisou a posição de comando de São Paulo durante a chamada República Velha (1889-1930). De acordo com o autor: "o papel de São Paulo na política federal de 1889-1930 foi único em razão das opções que se apresentaram aos estadistas paulistas. Conquanto São Paulo não pudesse dominar sozinho o Governo Federal, podia geralmente agir de acordo com Minas Gerais para controlar o Executivo Federal e, através dele, todo o Governo Central. Se São Paulo perdia para alguma combinação de outros poderes, podia ainda perseguir os próprios objetivos em virtude das suas imensas rendas estaduais e do seu poder de empréstimo. [...] Não
} 
Desse grupo político, priorizamos o protagonismo de dois políticos paulistas. O primeiro deles é Armando de Salles Oliveira, líder do Partido Constitucionalista, interventor de São Paulo entre 1933 e 1936 e candidato à presidência nas eleições previstas para janeiro de 1938, que não ocorreram devido ao golpe de novembro de 1937. Armando de Salles Oliveira nasceu na capital paulista, em 1887. Formou-se na Escola Politécnica e, entre os anos de 1923 e 1928, estudou na Sorbonne, em Paris, onde se especializou em eletrificação de estradas de ferro, tornando-se empresário no ramo de construção e direção de empreendimentos em serviços públicos. Casou-se com Raquel Mesquita, filha de Júlio Mesquita, presidente da Sociedade Anônima O Estado de S. Paulo, tornando-se responsável pela edição do jornal. Apoiou a Revolução de 1930 e participou ativamente da Revolução de 1932. O outro protagonista, Paulo Alfeu Junqueira de Monteiro Duarte, membro influente do Partido Constitucionalista e ferrenho opositor de Getúlio Vargas. Formado em Direito, Paulo Duarte iniciou seu envolvimento com a política em 1919, quando foi chamado para ser revisor do jornal O Estado de S. Paulo, tornando-se membro do grupo político do jornal e estreitando suas relações com Armando de Salles Oliveira. Paulo Duarte escreveu sobre sua vida pessoal e política em obra memorialística onde relata a experiência vivida como integrante do grupo político aglutinado em torno da liderança de Armando de Salles Oliveira. Além da obra memorialística, Duarte constituiu ainda um extenso arquivo, por ele cuidadosamente reunido, guardado e organizado ao longo de sua vida.

No período de1933 a 1945 evidenciamos a ativa atuação de Armando de Salles Oliveira e de seu grupo político no cenário político paulista e nacional, considerando, inclusive, seu tempo de exílio. A respeito das revoluções de 1930 e 1932, elas nos interessaram em sua dimensão memorial, ou seja, como tais acontecimentos foram registrados e significados na memória social sobretudo no que tange ao grupo político em questão. Priorizamos o enfoque no pensamento e ação deste grupo político paulista, representado pelos políticos Armando de Salles Oliveira e Paulo Duarte, no esforço em acessar a cultura política de oposição ao varguismo.

obstante, a história se complica não só pela mudança das "regras do jogo" depois de 1930, mas também pela natureza mudável do Governo, tanto no nível federal quanto no nível estadual" (1982, p. 58). 
A escolha da atuação de Armando de Salles Oliveira e seu grupo políticopartidário como objeto de estudo se deu por sua importância no jogo político regional e nacional no período de 1933 a 1945, com destaque para os anos de 1933 a 1937, período em que Armando de Salles Oliveira se mantém à frente do governo de São Paulo. Como se trata de um grupo derrotado naquele jogo político, a memória construída acerca dessa experiência silenciou sua especificidade, ao incorporá-la e domesticá-la no discurso homogeneizador, vitorioso e continuísta de uma história desse período que conflui e deságua na "Era Vargas". Com efeito, na historiografia e na memória social que abastece esta, a experiência política de Vargas entre 1930 e 1945 é representada como uma continuidade, um bloco coeso, um "destino inexorável", que desconhece e constrói silêncio sobre os conflitos específicos entre as elites e o governo federal e até mesmo intra elites. A identificação de um projeto político, expresso no programa do Partido Constitucionalista - e em parte executado - por Armando de Salles Oliveira e seu grupo político, permitiu tecer um quadro mais acurado acerca da posição de São Paulo no jogo político nacional durante os anos de 1933 e 1945. Pensar o projeto político de Armando de Salles Oliveira e de seu grupo parece-nos ser um desafio e uma exigência para melhor compreender esse complexo e conturbado período da história republicana e sua importância no advento do Estado Novo.

Nossa proposta de estudo partiu de um primeiro questionamento: a historiografia, ao significar os acontecimentos de 1937 como continuação lógica de 1930, tratando os projetos políticos vencidos como irrelevantes e, como tais, ignorados e relevados ao esquecimento, não estaria simplesmente antecipando o futuro do passado, sequestrando a historicidade de seus atores contemporâneos? Se considerarmos a memória o primeiro contato da história com o passado, como defende Paul Ricœur (2001), não há como deixar de indagar: de que maneira e qual memória estaria alimentando a interpretação da história que significa o projeto político paulista como proposta vencida e, como tal, objeto de uma política de silenciamento por parte da historiografia e da memória social? Seriam, de fato, relevantes e ameaçadoras ao projeto continuísta de Getúlio Vargas, as propostas e ações de Armando de Salles Oliveira e de seu grupo na política nacional? Responder a tais questões é o desafio que abraçamos ao longo da constituição da presente tese. 
Ao historicizar o percurso político de Armando de Salles Oliveira e de Paulo Duarte, e também, transversalmente, o do grupo político do jornal O Estado de $S$. Paulo, buscamos desnaturalizar uma memória histórica em que as relações entre presente e passado são vistas como continuidade e sequências naturais, ou seja, 1937 como desfecho lógico de 1930, por exemplo. Trata-se de esforço de historicizar que implica desnaturalizar construções de uma historiografia que domestica o passado, ao legitimar e justificar o vencedor, apaziguando tensões, disputas e ressentimentos, ao construir um silêncio sobre o protagonismo dos vencidos. Buscamos ainda priorizar o eixo da cultura política como chave de leitura para apreender, em determinado momento e espaço da experiência histórica brasileira, o comportamento político - individual e coletivo - dos atores sociais, privilegiando suas orientações, seus pensamentos e ações, suas experiências e expectativas, expressas em múltiplas linguagens e códigos socialmente compartilhados.

Esta tese foi pensada a partir de três movimentos interdependentes: em primeiro lugar, buscamos identificar e analisar o pensamento e as ações de Armando de Salles Oliveira e seu grupo político a partir de sua ascensão à interventoria de São Paulo, em agosto de 1933, até o momento da instalação da campanha eleitoral de 1937. Em um segundo movimento, abordamos a dinâmica do jogo político da época através da cobertura que o jornal O Estado de S. Paulo, órgão de imprensa representante do Partido Constitucionalista, fez das eleições marcadas para janeiro de 1938, com destaque para as composições e disputas entre as elites políticas paulistas e outras elites da federação; por último, informadas pelos escritos memorialísticos e pelo arquivo político de Paulo Duarte acerca das experiências vividas junto ao grupo político de Armando de Salles Oliveira, buscamos restituir o laço entre história e política, identificando as disputas de memórias que se travaram no campo da cultura. É indispensável ressaltar que a problematização do lugar ocupado pela escrita memorialística e pelo arquivo na escrita da história, relacionando história, memória e poder é exigência que se colocou para nós ao longo da pesquisa e constituição da tese.

No caso da identificação e análise do projeto de Armando de Salles Oliveira e seu grupo político, a utilização do conceito de cultura política foi indispensável para o exercício de inteligibilidade buscado. Tal como Serge Berstein, entendemos que 
cultura política é um "sistema de representações portadoras de normas e valores que constituiriam a identidade de grandes famílias políticas". Ao compreender cultura política deste modo, Berstein aprofunda a definição proposta por JeanFrançois Sirinelli, para quem a "cultura política se trata de uma espécie de código e de um conjunto de referentes, formalizados no seio de um partido ou, mais largamente, difundidos no seio de uma família ou de uma tradição políticas" (1998, p. 350). Identificar este código, este conjunto de representações comuns ao grupo político, "permitiria compreender as motivações políticas que levam tal grupo a adotar este ou aquele comportamento político" (1998, p. 359). Para Berstein, essa seria a função mais importante do estudo da cultura política de determinada sociedade em determinado espaço e período de tempo. Alinhada às reflexões de Jean-François Sirinelli e Serge Berstein, Ângela de Castro Gomes destaca a importância do estudo da cultura política para a compreensão do comportamento político dos atores históricos, individual e coletivo:

É justamente o fato de o conceito de cultura política permitir explicações/interpretações sobre o comportamento político dos atores individuais e coletivos, privilegiando suas percepções, suas lógicas cognitivas, suas vivências, suas sensibilidades. Ou seja, realizando o exercício historiográfico que implica se deslocar no tempo e no espaço, compreendendo as orientações dos atores, segundo seus próprios códigos culturais. Um exercício clássico do ofício do historiador, que não pode cometer anacronismos em relação ao passado e não pode postular orientações normativas (o que deve ser), acreditando em uma concepção de tempo linear e progressivo, ou supondo homogeneidades e ausência de conflitos em sociedade (GOMES, 2005, p. 30).

Como também descartamos as orientações de uma concepção de tempo linear e processual, da homogeneidade e ausência de conflitos em sociedade e na história, uso do conceito de cultura política nos ajudou nesse esforço de historicização da experiência política de Armando de Salles Oliveira e seu grupo político, atentando para suas orientações, seus códigos culturais, suas lógicas e vivencias, seus comportamentos políticos. O projeto político paulista é abortado em 1937 e Armando de Salles Oliveira é submetido ao exílio forçado. Entretanto, durante o exílio, entre 1938 e 1945, o ex-candidato à presidência redigiu e destinou ao Brasil, algumas cartas, portadoras de suas memórias e de sua avaliação acerca da situação política daquele momento e também do passado. Os anos entre 1930 e 1937, período em que o grupo político armandista conseguiu ascender ao governo 
de São Paulo e executar parte de seu projeto político, deveriam, segundo a avaliação de Armando de Salles Oliveira, ser revisitados e repisados, a fim de se ter melhor compreensão do caminho que o levou ao exílio.

Para o desenvolvimento da tese, usamos também como fonte a imprensa ligada ao Partido Constitucionalista, o jornal O Estado de S. Paulo com suas matérias sobre o debate sucessório ocorrido no país por volta de dezembro de 1936 até novembro de 1937. A orientação, perspectiva e função desempenhadas pelo jornal O Estado de S. Paulo foram estudadas por Maria Helena Capelato e Maria Lígia Coelho Prado (1980), em O Bravo matutino (imprensa e ideologia no jornal O Estado de S. Paulo). As autoras apresentam a trajetória singular do jornal no quadro da imprensa brasileira. Pesquisamos o periódico entre os meses de dezembro de 1936 a novembro de 1937, momento em que se instalou com mais intensidade o debate sucessório. No que concerne ao trato do jornal, foi feito considerando-o não "fonte objetiva de verdade histórica", mas como uma narrativa construída sobre um evento. Afinal, entendemos como imperiosa a tarefa de atentar para as dimensões formativa, comprometida e pedagógica que informam a produção de qualquer jornal, visto como artefato cultural não "meramente informativo, mas formativo de opinião" (BORGES, 1979, p. 14).

Manoel Salgado Guimarães (2006), ao refletir sobre as narrativas históricas que domesticam o passado segundo a visão e interesses localizados no presente, ressaltou a dimensão do exercício de poder operante em toda escrita da história. Entendemos também a construção da memória como operação atravessada por relações de poder. Daí a importância da análise crítica dos discursos da imprensa, levando em consideração os interesses do grupo político armandista, articulados em seu órgão de imprensa. A imprensa armandista usou as representações do passado para fundamentar e legitimar o projeto político do grupo, assentando-o em bases sólidas, históricas, para os acordos estabelecidos no presente. O jornal O Estado de S. Paulo, como porta voz do grupo político de Armando de Salles Oliveira foi, estrategicamente, o canal usado e priorizado para divulgar e formar uma opinião pública favorável ao projeto político de aspiração nacional sob a hegemonia de São Paulo. Neste, o grupo afirmava defender a unidade nacional, respeitando a autonomia das federações e, acima de tudo, assegurando a defesa da democracia e da Constituição. 
Por fim, as memórias registradas por Paulo Duarte e o arquivo político por ele organizado constituíram fontes importantes para compreensão do pensamento e ação do grupo político aglutinado em torno da liderança de Armando de Salles Oliveira. Publicadas entre os anos de 1974 e 1979, Paulo Duarte rememorou sua vida, pessoal e política, detalhadamente, ao longo de nove tomos. Com o golpe que fundou o Estado Novo, os governantes de São Paulo ligados ao grupo seguiram caminho do exílio. No caso de Paulo Duarte, tratava-se de segundo exílio, que durou até 1945. Além de ter sido deputado constituinte em 1934, participou e acompanhou de perto o governo de Armando de Salles Oliveira em São Paulo. Seus diálogos com o ex-governador e impressões sobre os anos em que Vargas esteve no poder, constituem fontes preciosas para o entendimento do projeto político armandista. Paulo Duarte fez parte da comunidade política do jornal O Estado de S. Paulo, do qual foi correspondente em Paris. Como chefe de gabinete do prefeito Fábio Prado, ajudou a dar andamento ao projeto político armandista, que propunha fazer de São Paulo vitrine para o Brasil. Em seus registros, é possível perceber seu empenho em separar as memórias pessoais e políticas. Assim, em seu arquivo, as memórias pessoais seguem o fluxo dos sentimentos, enquanto as memórias políticas são condicionadas aos diversos documentos, cuidadosamente selecionados por ele, ${ }^{3}$ vistos como provas irrefutáveis dos fatos relatados (SANDES, 2011). Ao eleger as memórias e o arquivo de Paulo Duarte como objeto de estudo, estamos de acordo com Lucilia Neves Delgado,

História, tempo e memória são processos interligados. Todavia, o tempo da memória ultrapassa o tempo de vida individual e encontrase com o tempo da história, visto que se nutre, por exemplo, de lembranças de família, músicas, filmes, tradições, histórias escutadas e registradas. A memória ativa é um recurso importante para transmissão de experiências consolidadas ao longo de diferentes temporalidades (2010, p. 17).

No caso de Paulo Duarte, a memória e o arquivo foram recursos para transmitir e consolidar a experiência do grupo político do qual ele fazia parte. Uma maneira também de permanecer na história política do país.

\footnotetext{
3 Paulo Duarte, ao compor suas memórias, embasado por cartas e outros documentos, fazia questão de apresentar cópias destes. O hábito de guardar documentos e cópias das correspondências, enviadas e recebidas, é revelador do desejo premeditado de constituição de um arquivo. Seu arquivo foi adquirido pela Unicamp, nos anos 70, e se encontra no Centro de Documentação Cultural Alexandre Eulálio (CEDAE), do Instituto de Estudos de Linguagem (IEL), para onde foi transferido após sua morte (ZIOLI, 2010, p. 105).
} 
Embora Duarte tenha o cuidado em consultar documentos para melhor reavivar a memória e, em seguida, tece-las, a traição política por parte de Getúlio Vargas é evento ordenador de suas lembranças, registradas com o visível viés do ressentimento. Pierre Ansart (2004), ao pensar as relações tecidas entre história, memória e ressentimento, explicita em questionamento central: "que memória conserva um grupo de seus próprios ressentimentos e dos ressentimentos dos inimigos dos quais foi vítima?" (p. 30). No caso de Paulo Duarte, a aversão ao getulismo permeou sua narrativa ao longo dos nove tomos. Foi também essa aversão e vontade de combate à ditadura varguista que manteve o grupo unido durante o exílio, mesmo com as querelas internas.

A escolha por Paulo Duarte ancorou-se em nosso argumento em defesa de outra possibilidade de leitura de experiências políticas dos anos 1930-1945, a que prioriza os grupos políticos derrotados pelo golpe de 1937 e pelo varguismo. Paulo Duarte foi político representante do grupo armandista e símbolo de oposição a Getúlio Vargas. Ele situa-se no campo político de franca, intransigente e explicita oposição ao varguismo. Significativamente, esta cultura de oposição a Vargas encontrou terreno e expressão em São Paulo, e particularmente em Paulo Duarte, pois foi estado da federação e a geração política deslocada de posição por conta dos movimentos dos revolucionários de 1930, particularmente do governo de Getúlio Vargas. As memórias do grupo armandista nos ajudarão a acessar a cultura política que formava e informava a ação de oposição ao varguismo, sua lógica, seus códigos, sensibilidades, representações e práticas políticas. Segundo Eliane Dutra, “a memória é elemento também essencial na análise das culturas políticas. Colocadas na encruzilhada das representações coletivas do passado, do presente e do futuro, as culturas políticas são também codificadas e transmitidas pela memória" (DUTRA, 2002, p. 26).

Ao destacarmos as tensões e também diálogos entre memória e história, estamos de acordo com Halbawachs (2006), que mostra como recompor o passado sob a forma de memória histórica é resultado de um processo de negociação, que se dá com a troca entre impressões pessoais e lembranças do que foi vivido. Processo similar ocorre na narrativa de Paulo Duarte, que teceu suas memórias com claro sentido de propagar um sentimento de antigetulismo. Ao escolher as memórias do ex-revolucionário e exilado como fonte buscamos atentar para essa tensão, de 
modo a perceber, como, no curso de suas lembranças, o romantismo revolucionário cedeu espaço ao realismo político. "Na maior parte das vezes, lembrar não é reviver, mas refazer, reconstruir, repensar, com imagens e ideias de hoje, as experiências do passado. A memória não é sonho, é trabalho" (BOSI, 1979, p. 33).

Recusar as já clássicas construções de uma memória histórica que dá ênfase aos projetos políticos vencedores e sacraliza-os, como a construída sobre a era Vargas, e seu principal agente, o presidente que dá nome à mesma, demandounos dialogar com Paul Ricœur. Este, em sua obra A memória, a História, o Esquecimento (2007), chamou a atenção para o trato dos documentos escritos deixados nos arquivos, que já não possuem mais quem fale por eles, não são somente mudos, mas também órfãos por terem se desligado daqueles que os colocaram no mundo. A partir de então, estarão submetidos aos cuidados de quem irá interrogá-los. É justamente nesse momento que a operação técnica aplicada a esses documentos pode ser prejudicial para sua memória.

Pensamos que, relativamente à experiência paulista, a operação historiográfica que colocou Vargas na centralidade dos eventos políticos do período em questão foi mais veneno que remédio, pois supervalorizou o projeto varguista vencedor, subestimando e/ou silenciando os demais projetos políticos, tratando-os como se tivessem nenhuma ou pouca importância na experiência histórica brasileira. A voz de Armando de Salles Oliveira e do grupo paulista derrotado foi vista como a voz de fantasmas, de vencidos, ressentidos, "reles intrigantes", que nem chegaram efetivamente a perturbar seriamente o governo Vargas. Tais construções historiográficas remetem-nos ao campo da disputa entre memória e história e, portanto, das relações de poder que presidem tal disputa, a do controle da memória vencedora que se impõe como verdade histórica e memória oficial. Vesentini (1997) igualmente nos ajuda a pensar como a memória do vencedor é sobreposta à memória do derrotado, constituindo assim a história oficial, ao refletir sobre a operação que transformou a Revolução de 1930 em "fato". Instituído o fato, cabe aos historiadores questionarem o que ficou de fora, excluído pela ordenação da trama instituída que se impôs como parâmetro de análise do acontecimento.

Também nos orientamos pela reflexão de Paul Ricœur (2001), que alertanos para o fato de que por conhecermos o futuro do passado, lançamos nossos olhares para este como se ele já estivesse determinado, enquanto olhamos para o 
futuro como possibilidade de algo aberto. Informados pela memória histórica do vencedor e, desse modo, distanciados do espaço de experiência e do horizonte de expectativa dos grupos derrotados, domesticamos nosso olhar sobre o passado consoante a leitura que estabelece como verdade a visão do vencedor. Questionar e desnaturalizar tal olhar é exigência colocada aos do ofício, pois o tecido histórico é complexo, múltiplo, difuso e diverso. Nosso trabalho é fazer o inventário dessas diferenças, como nos ensina Paul Veyne (2014).

As indagações que nos levaram a elaborar esta tese exigiram-nos uma incursão pelo campo da cultura, da leitura do mundo como representação, das narrativas e escritas da história, particularmente da complexa relação entre memória, história e poder. Nesse sentido, a história não pode ser vista como processo em que os fatos já estão aprioristicamente determinados por um passado inexorável (BORGES, 1998). A história da experiência política do grupo de Armando de Salles Oliveira e seu projeto político de poder não pode ser vista apenas como a de um grupo derrotado com um passado interrompido, um destino não cumprido, mas como a emergência de um obstáculo, uma experiência que escapa ao compasso homogeneizante de uma história modelar, pré-determinada, presa a modelos explicativos. Priorizamos estudar tal experiência, portanto, em sua singularidade, enfim, em sua historicidade, e não como uma conclusão lógica de outro fato. Lembrando Ricoeur (2001): o passado está aberto e tinha um futuro.

No primeiro capítulo buscamos mostrar as primeiras aproximações e os primeiros distanciamentos entre Salles Oliveira e Vargas, assinalando como ambos foram importantes para que o projeto político do grupo armandista fosse desenvolvido. Mostramos ainda como esse projeto era centrado em três pilares: além da criação do Partido Constitucionalista, outras duas ações seriam implementadas na interventoria de Salles Oliveira: a que investia na educação e na cultura, com a fundação da Universidade de São Paulo, e a que priorizava a eficiência administrativa na governança da prefeitura, sob a gestão de Fábio Prado. Ainda neste capítulo, buscamos mostrar como o jogo político desenvolvido entre 1934 e 1936 contribuiu tanto para a elaboração e execução de um golpe de estado, como para que o grupo armandista construísse a candidatura Armando de Salles Olveira à sucessão presidencial. Assim como Vargas, o grupo político armandista também se alimentou da crise inventada da ameaça comunista para mobilizar 
adesões e divulgar seu programa político. Não por acaso, democracia e defesa da Constituição foram as bandeiras levantadas pelo grupo armandista durante a campanha eleitoral.

No segundo capítulo apresentamos a campanha eleitoral disputada pelo grupo político armandista, que teve seu ponto alto em 1937. Visando às eleições previstas para 3 de janeiro de 1938, Armando de Salles Oliveira descompatibiliza-se do governo de São Paulo e lança-se candidato à Presidência ainda em dezembro de 1936. Trata-se de momento conturbado, com uma nova redefinição nas alianças políticas, tendo em vista que Getúlio Vargas não apoiou a decisão do político paulista. Além de Salles Oliveira, concorreram às eleições o candidato apoiado pelo Partido Republicano Paulista, José Américo de Almeida, e Plínio Salgado, candidato da Ação Integralista Brasileira. Neste capítulo, analisamos a cultura política que orientava a ação do grupo político de Armando de Salles Oliveira, entre 1936 e 1937, priorizando os seguintes aspectos: o debate eleitoral entre os candidatos; as alianças políticas estabelecidas, o papel da imprensa como porta voz de um partido político; as estratégias de campanha do candidato Salles Oliveira.

No terceiro e último capítulo, consideramos as ideias, as forças políticas, as disputas, os acordos, os projetos que levaram ao Estado Novo, mas sob a perspectiva das memórias de Paulo Duarte, organizadas em volumoso arquivo, publicadas em nove tomos. Neste capítulo, nosso principal interesse foi o de buscar apreender o que o autor significa como central em suas memórias e os ressentimentos exteriorizados e também subsumidos em sua narrativa. Os registros acerca da experiência política vivenciada entre 1933-1945 são fontes repletas de informações e possibilidades de análise. Interessou-nos também recompor o quadro do exílio para identificar as estratégias de luta política do grupo armandista que, apesar e por conta do exílio, tentou articular uma intervenção na política do país durante os anos de ditadura.

Na obra, história e memória demarcam um campo de experiência e de expectativa, um tempo histórico que não pode ser desconsiderado na análise do jogo político nacional daquele período. Na narrativa construída por Paulo Duarte é possível perceber o tenso diálogo entre memória e história, na busca de um sentido no relato que tece dos acontecimentos passados. Repensar as estratégias traçadas outrora foi caminho pensado pelos derrotados para buscar identificar as razões do 
fracasso de seu projeto político de ascensão ao poder. A oposição ao governo Vargas definiu o projeto político e também de vida de muitos armandistas, dentre eles, Paulo Duarte. Assim, procuramos historicizar também a construção dessa memória, ressaltando o lugar ocupado pela escrita memorialística de Paulo Duarte na produção de um discurso de oposição ao discurso varguista hegemônico. Inclusa a produção memorialística de Paulo Duarte, a arquivistica, organizada por ele como suporte material e sustentação de suas memórias. Entendemos que tal produção tenha justamente em mira legitimar suas memórias, vista por ele como matéria prima básica para escrever a "verdadeira" história daquele período.

Por fim, ressaltamos que nossa pesquisa teve em vista criticar e desnaturalizar uma determinada memória histórica ${ }^{4}$ em que as relações entre presente e passado são vistas como continuidade e sequências naturais: 1937 como desfecho lógico de 1930, como tratado pela historiografia brasileira, hegemônica nos anos 1940-1980. Esse tipo de memória histórica privilegia e domestica o passado segundo a visão do vencedor, silenciando as ações e visões dos vencidos. Ao considerar a dinâmica do jogo político praticado, as memórias e o arquivo de Paulo Duarte, estamos apostando em outras possibilidades de escrita da história da experiência republicana de 1933-1945. Nosso entendimento é o de que fica retido na memória histórica como resíduo, não são apenas os agentes políticos, mas também um projeto derrotado. Esse sim é o grande vencido, por estar no ostracismo (VESENTINI, 1997). Nessa lógica, o consenso quanto à interpretação do "golpe silencioso" de 1937, apoiado pela maioria das elites dirigentes, apresentava um veto para alternância política, justamente a do retorno do grupo paulista, vitorioso nas eleições de 1934 e ansioso pela sucessão presidencial.

\footnotetext{
${ }^{4}$ De acordo com Carlos Alberto Vesentini, entendemos memória-histórica como a memória que se institui através de uma historiografia que privilegia determinadas leituras do passado em detrimento de outras.
} 


\section{CAPÍTULO I: ARMANDO DE SALLES OLIVEIRA E SEU GRUPO POLÍTICO: UM PROJETO PARA O BRASIL}

Após a revolução de 1930, Getúlio Vargas precisou negociar com o grupo político paulista, liderado por Armando de Salles Oliveira, em vários momentos. Dois desses momentos foram decisivos no quadro político nacional: após a revolução de 1932 - quando a Assembleia Nacional Constituinte foi convocada e Vargas queria garantir a presidência constitucional -; e em 1936, após a Intentona Comunista, quando o debate pela sucessão presidencial estava prestes a ser instalado e Vargas deu início ao cerceamento das liberdades, com intenção de garantir a prorrogação de sua gestão. Negociar durante esses dois momentos também foi de extrema importância para o grupo político armandista. A revolução de 1932 trouxe a chamada da Constituinte e, com ela, a indicação de Salles Oliveira à interventoria de São Paulo. $\mathrm{O}$ fortalecimento dos projetos extremistas de poder e o acirramento dos ânimos entre 1935 e 1936 trouxe a oportunidade de Salles Oliveira consolidar a imagem de único político capaz de fazer o Brasil continuar. Nesse sentido, se os anos 1930 foram palco de Getúlio Vargas e seu projeto político de modernização conservadora, que enterraria de vez a República Velha, começando com a revolução de 1930, foi também palco de um grupo político, oriundo da elite política paulista, vinculado ao jornal O Estado de S. Paulo, que tinha um projeto político de poder, cuja base seria São Paulo e se estenderia a todo Brasil.

Joseph Love, em seu estudo, A Locomotiva: São Paulo na federação brasileira (1889-1937), definiu a elite política paulista como "composta pelos ocupantes dos cargos mais importantes no governo e nos partidos dominantes, tanto a nível estadual como federal" (1982, p.215). O autor estudou todos os 263 políticos que formaram a elite política paulista entre 1889 e 1937, dentre eles, o grupo político que nos interessa, aglutinado em torno do Partido Constitucionalista. Trata-se do grupo político liderado por Salles Oliveira, ao qual nomeamos como grupo do jornal O Estado de S. Paulo ${ }^{5}$ ou grupo dos armandistas. ${ }^{6}$ Do mesmo modo que

\footnotetext{
${ }^{5}$ É importante ressaltar que os dirigentes $d^{\prime} O$ Estado de $S$. Paulo alegavam que o periódico não era órgão oficial do Partido Constitucionalista, mas é certo que havia uma identificação nas proposições políticas do jornal e do partido, não obstante as concepções peculiares do grupo político do Estado de S. Paulo (CAPELATO; PRADO;
} 
identificamos e reconhecemos o grupo político do jornal O Estado de S. Paulo, ou grupo político armandista, nas figuras de seus principais líderes - Júlio de Mesquita Filho, Armando de Salles Oliveira, Francisco Mesquita, Francisco Morato, Paulo Duarte, Paulo Nogueira Filho, Vivaldo Coaracy -, não desconhecemos que vários outros integrantes da elite política paulista colaboravam com o jornal e partilhavam da mesma ideologia e projeto de poder. ${ }^{7}$ É importante ressaltar ainda que o grupo estava constantemente envolvido em alianças políticas até mesmo com os que foram considerados "inimigos" em outros tempos. Veremos algumas dessas alianças neste capítulo.

Sob a liderança de Salles Oliveira, esse grupo político aglutinava-se em torno de um projeto político de poder que começou a ser executado na capital paulista desde a ascensão daquele político à interventoria e depois ao governo de São Paulo, em agosto de 1933. A cidade de São Paulo tornou-se uma amostra, um projeto piloto, do que seria o Brasil sob o governo do Partido Constitucionalista. Escolhida por ser berço político do grupo político armandista, aquela cidade tornouse então uma espécie de vitrine do governo armandista. Nesse governo, foi dada prioridade à modernização do estado, a ser viabilizada por um sistema de educação, de política cultural e de partidos políticos ferreamente disciplinados e de âmbito nacional (FERREIRA, 2007). A imagem de "locomotiva" que puxava os demais vagões, carregando o peso dos outros Estados, com a qual os paulistas se identificaram durante muito tempo, foi estrategicamente deslocada de sua centralidade pela imagem de São Paulo como espelho para nação.

Neste capítulo iremos apresentar as aproximações e distanciamentos entre Getúlio Vargas e o grupo político paulista armandista, com destaque para os dois

\footnotetext{
1980, p. 33).

${ }^{6}$ Segundo Vilfredo Pareto a "elite" seria constituída por uma classe de indivíduos detentora dos índices mais altos nos seus respectivos ramos de atividade. Essa elite seria dividida em governante e não governante. Já Gaetano Mosca compreende que em todas as sociedades haveria a classe de pessoas que é dirigente e a que é dirigida. Tanto a definição de Pareto quanto a de Mosca referem-se a um grupo minoritário de pessoas que participaram do processo de tomada de decisão política na esfera estatal. De modo que, as expressões "elite governante" e "classe política", pensadas, respectivamente, por Pareto e Mosca, servem de parâmetro para a compreensão das elites políticas paulistas que concorreram pelo poder em São Paulo durante a década de 1930. (ZUCKERMAN, Alan. Elite política: lições de Mosca e Pareto. In: BOTTOMORE, T. B. et. al. Elites políticas. Brasília: UNB, 1978. p. 12-14).

7 Em concordância com Norberto Bobbio, o termo "ideologia" foi aqui empregado com o sentido de definir "um conjunto de ideias e valores respeitantes à ordem pública e tendo como função orientar comportamentos políticos coletivos". (BOBBIO, Norberto; MATTEUCI, Nicolas; PASQUINO, Gianfranco. Dicionário de política. Vol. I, 11. Ed. Brasília: UNB, 1998).
} 
principais momentos em que ambos precisaram negociar: em 1933-1934, com o debate que sucedeu a Assembleia Nacional Constituinte, e em 1936, com a instalação do debate sucessório que visava às eleições presidenciais, marcadas para janeiro de 1938. Através da análise desses movimentos será possível perceber que, ainda que Getúlio Vargas e o grupo político armandista tivessem projetos políticos bem articulados e definidos, foi no jogo político envolvendo esses atores e antagonistas que se definiu o resultado: a derrota do projeto político de Salles de Oliveira e a vitória de Getúlio Vargas. Nem sempre as expectativas desses protagonistas foram concretizadas e constantemente o percurso pretendido sofreu alterações.

A respeito da situação política vivenciada no Brasil entre os anos de 1930 e 1937, Paulo Sérgio Pinheiro propõe a seguinte interpretação:

Em vez de se considerar esse período (1930-1934) como um interregno provisório para uma democracia constitucional que viria em 1934 - a qual será interrompida pelo golpe de Estado em 1937 é possível propor uma outra periodização. O governo provisório de 1930-1934 já é a ditadura - interrompida por um breve período de menos de um ano que seria retomada pelo golpe de Estado de 1937. (PINHEIRO, 1991, p. 269-270).

Tal maneira de interpretar coloca em evidencia a dicotomia "ditadura $\mathrm{x}$ democracia" (COHEN, 1997), tão reiterada na/pela historiografia acerca do tema, reduzindo a dois polos uma experiência que foi bem mais complexa. Para Ângela de Castro Gomes (2007), o fato da experiência constitucional de 1934 ter sido de curta duração não afeta sua importância no curso dos acontecimentos políticos daqueles anos. Segundo a historiadora:

Para nós, nesse sentido, não é tão significativo o fato de a Constituição de 1934 ter tido curta duração, sendo fundamentalmente solapada, já em 1935, pela Lei de Segurança Nacional, e finalmente tornada inútil, em 1937, pelo golpe do Estado Novo. Seu valor e presença enquanto experiência histórica não estão no tempo de sua vigência, mas no processo que a gerou, pleno de revisões e reflexões sobre nosso passado e futuro políticos. (GOMES, 2007, p. 71).

Perceber, no processo político do período, a experiência vivida em São Paulo pelo grupo político armandista parece-nos fundamental para compreender aquele, para acessar sua complexidade e amplitude, não obstante sua relativa curta 
duração e pensarmos a atuação daquele grupo a partir de alguns eventos. A indicação para interventoria de São Paulo e a chamada da Assembleia Nacional Constituinte em 1934; o governo de Armando de Salles Oliveira entre 1934 e 1936; a atuação diante da ascensão da Aliança Nacional Libertadora (ANL) e da Ação Integralista Brasileira (AIB); por fim, o debate sucessório para as eleições presidenciais de janeiro de 1938. São experiências importantes que nos permitem acessar e adentrar o intricado quadro político que levou Getúlio Vargas ao golpe de Estado de novembro de 1937. Nesse modo de pensar, excluímos a tese de que a instalação do Estado Novo teria sido um desfecho natural da revolução de 1930. Excluindo, também, a imagem da política paulista como refém de um projeto político equivocado, portanto, derrotado. A elaboração e execução do projeto político paulista do grupo em questão, atendeu, também, às demandas de seu tempo. Seus mentores tinham expectativas reais de que pudesse ser concretizado, e o foi, até certo momento.

\title{
1.1. A indicação de Armando de Salles Oliveira para interventoria de São Paulo: aproximações com Getúlio Vargas e o projeto político de poder ${ }^{8}$
}

\begin{abstract}
Vieste com o objetivo exclusivo de fazer a Constituição. Na altura a que os acontecimentos nos trouxeram, deixaram efetivamente de nos interessar os perigosos ajustes de contas, as incandescentes retaliações de puro personalismo e, ainda, as estéreis discussões sobre o ser ou não ser destes últimos três anos de governo discricionário. Fiel às suas ideias, São Paulo procura colaborar ativamente com os delegados dos outros Estados, para garantir a vida da Constituição (OLIVEIRA, 2002, p. 28).
\end{abstract}

O trecho acima é do discurso proferido no Rio de Janeiro, em dezembro de 1933, por Armando de Salles Oliveira, no almoço oferecido pelos deputados constituintes de São Paulo. Ao classificar os acertos de contas como perigosos, o interventor orientou a bancada paulista a deixar de lado os ressentimentos criados durante os anos que sucederam à revolução de 1930. Armando de Salles Oliveira se referia aos ressentimentos nutridos desde a vitória da revolução de 1930, quando

\footnotetext{
${ }^{8}$ Parte da discussão proposta neste tópico, especificamente no que diz respeito à relação da elite política com Vargas entre 1930 e 1934, foi construída a partir textos já publicados, produzidos pela autora do presente trabalho. Para consulta ver (SOUSA, 2012; 2013).
} 
Vargas não cumpriu com o combinado de colocar um interventor civil e paulista para governar São Paulo, o que culminou com a revolução de $1932 .{ }^{9}$ Também era estéril a discussão a respeito do Governo Provisório "ser ou não ser" uma ditadura. Armando de Salles Oliveira havia sido indicado interventor em agosto daquele mesmo ano, ou seja, pouco antes do debate constituinte ser instalado. Diante desse quadro, é possível concluir que, naquele momento, a relação entre o interventor paulista, Armando de Salles Oliveira, e o chefe do Governo Provisório, Getúlio Vargas, teria sido orientada no sentido de esquecer os ressentimentos para possibilitar a votação da Constituinte.

O processo de constitucionalização, que se instalou nos anos de 1933 e 1934, ocorreu em meio a redefinições de alianças políticas. Getúlio Vargas precisou conseguir bases de sustentação antes que os debates constituintes se iniciassem. Ainda que a candidatura de Vargas à presidência constitucional fosse assunto acertado desde a instalação da Assembleia Nacional Constituinte, não era uma eleição garantida. Até os dias finais do debate constituinte, Vargas teve que barganhar sua permanência no poder, fazendo articulações e utilizando os recursos políticos de que dispunha. Naquele momento, seus principais adversários eram os paulistas, que radicalizaram sua oposição de forma belicosa, em uma guerra civil contra o Governo Provisório, em 1932. Mesmo derrotado militarmente, São Paulo conseguiu atrair para si todas as atenções nacionais e a postura de sua bancada durante o debate constitucional era promissora (GOMES, 1996). Segundo Ilka Stern Cohen, a derrota dos paulistas na revolução de 1932 foi considerada uma espécie de vitória moral, uma vez que, apesar de derrotados, os paulistas teriam conseguido trazer a abertura do debate constituinte.

Três meses e mais de 600 mortos depois, os paulistas se renderam e os políticos envolvidos no movimento foram presos e exilados. Sufocando o movimento, Getúlio Vargas marcou eleições para a Constituinte para maio de 1933, num gesto de aproximação com os políticos de São Paulo. A convocação foi imediatamente assumida como uma vitória moral: "Perdemos, mas vencemos" tornou-se a versão oficial do episódio (2012, p. 43).

\footnotetext{
${ }^{9}$ Ao invés de indicar um interventor civil e paulista, Getúlio Vargas nomeou o pernambucano João Alberto, tenente partícipe da Coluna Prestes. As desavenças entre os paulistas e Vargas se iniciaram. Ainda passariam pela interventoria paulista Laudo de Camargo e Pedro de Toledo, em curto espaço de tempo, mostrando, assim, a instabilidade em que se encontrava a política de Vargas com relação a São Paulo. Ficava evidente que Getúlio Vargas estava evitando entregar São Paulo nas mãos de membros do Partido Democrático. Os desentendimentos culminaram na revolução de 1932.
} 
Quando Armando de Salles Oliveira orientou a bancada paulista a não se ater às "estéreis discussões do ser ou não ser" daqueles últimos três anos, estava falando justamente da necessidade de não trazer para o debate constituinte os sentimentos de ressentimento ou de vitória moral criados com a revolução de 1932. Um exercício difícil para bancada política paulista, tão orgulhosa de ter feito a revolução contra Vargas. Entretanto, tal exercício de contenção dos sentimentos e ressentimentos não pode ser confundido com esquecimento dos mesmos, é necessário considera-lo como estratégia para compreender qual o movimento do grupo político armandista naquele momento.

Ângela de Castro Gomes, Lúcia Lahmeyer Lobo e Rodrigo Bellingrodf Coelho escreveram o artigo Revolução e Restauração: a experiência paulista no período de Constitucionalização (1996), no qual examinam o caso de São Paulo no momento imediato após a derrota de 1932 até a reconstitucionalização do país. ${ }^{10}$ Este contexto foi considerado pelos autores como marca da reintegração de São Paulo ao cenário político nacional. Os percursos políticos de São Paulo entre a Revolução de 1930 e a promulgação da Constituinte em 1934 foram marcados por uma divisão: de um lado "uma situação de conflito e total radicalização da reação política - a Revolução de 1932; de outro, uma posição de participação no poder, indicativa de absorção, esvaziamento e conciliação de divergências" (GOMES; LOBO; COELHO, 1996, p. 243), traduzida na nomeação de Armando de Salles Oliveira para a interventoria de São Paulo. Adiante nos propomos a analisar as tensões e acordos que presidiram a relação entre Salles Oliveira e o chefe do Governo Provisório, com atenção para as estratégias de aproximação e distanciamento entre a elite paulista armandista e o governo federal. A nosso ver, o esvaziamento das divergências ocorreu como estratégia política que não deixou de se encontrar atravessada pelo ressentimento.

\footnotetext{
${ }^{10} \mathrm{O}$ artigo de Ângela de Castro Gomes, Lúcia Lahmeyer Lobo e Rodrigo Bellimgrodf Coelho é fruto de um grupo de estudos acerca da Revolução de 1930, fundado em 1976, no CPDOC. O grupo enfocou a emergência de novos partidos políticos, o desenrolar do debate constitucional dos anos 1930, os interventores estaduais e suas ligações com o governo central. Tal olhar atento permitiu a identificação das relações de "confronto e compromisso no interior das elites que participaram do jogo político de poder" naqueles anos. Para mais, consultar também: GOMES, Ângela Maria de. et al. Regionalismo e Centralização Política: Partidos e Constituintes nos anos 1930. Rio de Janeiro: Nova Fronteira, 1980.
} 
Ao ser nomeado interventor de São Paulo por Getúlio Vargas, Salles Oliveira formalizou e exteriorizou um entendimento entre o Governo Provisório e os paulistas do Partido Democrático e da comunidade política do jornal O Estado de S. Paulo. Os autores de Revolução e Restauração explicitam bem os motivos da aproximação de Getúlio Vargas com os paulistas. Antes das eleições às cadeiras constituintes, que ocorreriam em 3 de maio de 1933, as principais forças políticas paulistas, que se constituíam basicamente com o Partido Republicano Paulista (PRP) e o Partido Democrático $(P D)^{11}$, se uniram ${ }^{12}$ para formar a Chapa Única por São Paulo Unido e concorrer ao pleito. O motivo do esforço para fazer essa união era a oposição ao "governo militar e tenente" de Waldomiro Lima, que estava coligado com o Partido da Lavoura $^{13}$ e o Partido Socialista Brasileiro ${ }^{14 .}$ A Chapa Única elegeu 17 das 22 cadeiras constituintes, ganhando, mais uma vez, a atenção do chefe do governo

\footnotetext{
${ }^{11}$ O PRP respondeu pela política paulista entre 1889 e 1926. Entretanto, as lutas internas que se instalaram no partido durante os anos vinte levaram alguns de seus membros à dissidência. $O$ desacordo entre perrepistas tornou o momento propício para que os grupos descontentes com a política em vigor aglutinassem-se em uma agremiação partidária de oposição. Em fevereiro de 1926, nasceu de uma dissidência do Partido Republicano Paulista a elite política "ilustrada", sob a denominação de Partido Democrático. A elite política perrepista ganhou a denominação de "carcomidos" e seu poder foi intensamente contestado (CASALECCHI, 1987). Maria Lígia Coelho Prado (1986) defende que o Partido Democrático teria ajudado a solapar as forças perrepistas entre 1926 e 1930, contribuindo, assim, com a composição nacional que, em outubro de 1930, retirou o Partido Republicano Paulista do poder. A autora destaca que a democracia exercida pelo Partido Democrático tinha contornos bem definidos, alcançando os chamados grupos ilustrados da burguesia paulista, que, naquele momento, reivindicavam espaço no círculo de poder. O Partido Democrático surgiu, portanto, dentro de uma conjuntura de desgaste de práticas políticas, na qual tiveram início os conflitos que afastaram Minas Gerais do pacto político com São Paulo, no final dos anos de 1920, culminando na formação da Aliança Liberal e na revolução de 1930.

${ }^{12}$ Essa união ocorreu mesmo com todos os conflitos causados pelas diferentes posições adotadas durante Revolução de 1930 e pelas mútuas acusações para justificar a derrota de 1932. A respeito da relação conflituosa entre Partido Republicano Paulista e Partido Democrático, entre 1930 e 1933, ver: BORGES, Vavy Pacheco. Getúlio Vargas e a Oligarquia Paulista. História de uma esperança e muitos desenganos, 1979.

${ }^{13}$ O Partido da Lavoura foi oficialmente fundado no início de 1933 , por manifesto do Instituto do Café aos lavradores. Nesse manifesto, o Instituto, apesar de suas finalidades administrativas, afirmou que não podia estar alheio ao importante momento político - a instalação da Assembleia Nacional Constituinte -, no qual os interesses dos lavradores deveriam estar presentes. De acordo com os termos do partido, os trabalhos da Assembleia Nacional Constituinte para elaboração da lei básica do país teriam que garantir o desenvolvimento da lavoura de café em São Paulo. O partido, como representante dos lavradores, teria importante papel na constituinte e o Instituto do Café não deveria limitar-se apenas à condição de mero espectador. Entretanto, o Partido da Lavoura conseguiu eleger apenas dois deputados para a Assembleia Nacional Constituinte: Antônio Augusto Covelo e Lino Morais Leme (GOMES, 1980).

14 O Partido Socialista Brasileiro (PSB) foi organizado em 1932, tendo como orientação os princípios da Revolução de 1930, ao mesmo tempo em que se voltava para a formação de um partido nacional. O interventor de São Paulo, Waldomiro Lima, foi o organizador prático da agremiação e seu inspirador ideológico. Assim, em sua fundação, o partido contou com o apoio das forças tenentistas nacionais e com o apoio do governo do Estado. O partido defendia os seguintes pontos: eleições indiretas para os executivos estadual e federal; instituição da representação de classes e, sobretudo, uma política de justiça social que garantisse a aplicação da legislação trabalhista. O programa do partido intencionava sensibilizar as classes urbanas trabalhadoras (GOMES, 1980).
} 
provisório que, temeroso da união dessas forças oposicionistas, tentou uma aproximação que se revelou aos olhos do restante do país como um acordo finalmente concertado com os paulistas em geral. Getúlio Vargas tinha motivos para temer aquela união. No momento de formação da Chapa Única, as elites políticas oriundas tanto do Partido Republicano Paulista quanto do Partido Democrático deixaram de lado suas diferenças não apenas por conveniência, mas partilharam de ideais comuns no que diz respeito a identidade paulista, como força, coragem, vigor, orgulho cívico, sentimentos reforçados com a Revolução de 1932 e que eram um forte caráter mobilizador. Naquele momento estava em jogo reintegrar São Paulo no cenário político nacional, de modo que a Chapa Única apresentou as melhores condições para vencer as eleições e assim o fez (COHEN, 1997). Vargas precisou aproximar-se da liderança da Chapa Única com o intuito de reduzir ou alterar o impacto de sua ação.

Com efeito, tal política de aproximação já apontava desde julho de 1933, quando Vargas aceitou o pedido dos paulistas para exoneração de Waldomiro Lima, solicitando ao interventor que passasse o cargo ao general Daltro Filho, comandante da segunda região militar. A nomeação deste era provisória, posto que era necessário organizar o terreno político nacional para que, logo em seguida, outro nome indicado assumisse definitivamente o cargo. Assim, em 16 de agosto de 1933, Salles Oliveira ocupou a interventoria de São Paulo. Para pensar a repercussão dessa indicação ao governo do Estado, os autores de Revolução e Restauração analisaram o jornal O Correio da Manhã, que entendeu a escolha de Salles Oliveira como um arranjo: o interventor garantiria ao Governo Provisório a moderação da Chapa Única durante os debates constitucionais e a interventoria de um civil e paulista, que agradava aos paulistas, permaneceria. Ao lado disso, a atuação da Chapa Única ficaria comprometida com a orientação do novo interventor, pois o trabalho de agora em diante seria conjunto.

A bancada paulista, sob a liderança de Salles Oliveira, ao se ausentar diante de muitas questões durante o debate constitucional, causou desapontamento na oposição. A omissão da bancada durante o debate constitucional seria consequência de um suposto acordo selado com Getúlio Vargas. No entanto, a bancada paulista restringiu sua ação parlamentar aos assuntos de matéria estritamente constitucional, mas posicionou-se de maneira firme quando o debate 
foi, por exemplo, a respeito da anistia dos revoltosos de 1932. Com tal atitude, mostravam que "São Paulo não poderia se omitir diante de um assunto que sensibiliza todos os paulistas" (OESP, 17/11/1933, p. 1). O mesmo ocorreu quando o debate foi a censura à imprensa e, também, o mérito pela convocação da Assembleia Constituinte.

E é preciso observar que a bancada paulista, liderada por Salles Oliveira, não se comportou da maneira esperada também em relação ao governo Vargas, apesar das concessões feitas por este - a própria convocação da Assembleia Nacional Constituinte fazia parte dessas concessões -, o que denotava que Getúlio Vargas não estava totalmente com o controle. Sob a direção da Chapa Única por São Paulo unido, a bancada se posicionou de forma favorável ao candidato da oposição, Borges de Medeiros, algo que incomodou Vargas. Afinal, a interventoria paulista já estava nas mãos de Salles Oliveira, escolha feita em sinal de uma política de reconciliação com São Paulo após a revolução de 1932. Além da interventoria, foram tomadas outras duas medidas fundamentais para neutralizar o confronto com a bancada paulista. A primeira delas foi outorgar a anistia aos participantes do movimento revolucionário de 1932, através do Decreto $n^{\circ} 24.297$, de 28 de maio de 1934. ${ }^{15}$ Em seguida, a suspensão da censura à imprensa, em 14 de julho de 1934, através do Decreto $\mathrm{n}^{\circ}$ 24.776. Tais medidas haviam sido reivindicadas exaustivamente pela bancada paulista durante o momento de abertura política, concedê-las às vésperas do pleito, portanto, teve claro sentido eleitoreiro por parte de Vargas (GOMES, 2007). Ceder ao grupo político paulista algumas conquistas foi fundamental para restabelecer a ordem após a revolução de 1932.

Ângela de Castro Gomes (1996) analisou a importância da revolução de 1932 no debate sobre legalização do regime político do país que se instaurou no pós-1930. A autora considera a Revolução de 1932 como acontecimento responsável pela inauguração do processo de reconstitucionalização do país, pelo

\footnotetext{
${ }^{15}$ Acompanhamos o debate sobre a anistia e o regresso dos exilados via jornal O Estado de S. Paulo, órgão de imprensa do grupo político de Armando de Salles Oliveira. A atuação de Armando de Salles Oliveira, na condição de interventor de São Paulo, foi noticiada pelo jornal diariamente. Os editoriais do jornal foram dedicados a cobrir o debate constituinte e a ação da interventoria de Armando de Salles Oliveira. A elite política paulista do Partido Democrático podia visualizar um cenário político favorável. Diferente dos dois primeiros anos que sucederam à Revolução de 1930, a elite paulista tinha agora o controle do poder em São Paulo e a constituição estava para ser promulgada. (Ver: SOUSA, Carolina Soares. Política: a arte de lembrar e de esquecer. Os projetos políticos paulistas (1933-1934). Dissertação de mestrado. UnB, 2012).
} 
término do regime de exceção instaurado nos dois primeiros anos daquela década. Derrotados militarmente, mas tendo conseguido o objetivo político anunciado com a revolução - a imediata reconstitucionalização do país -, os paulistas ganharam força e musculatura no governo provisório. Entretanto, a vitória militar sobre a revolução de 1932 assegurou a Vargas a legitimidade e o poder para conduzir o processo de constitucionalização instalado a partir de então. É certo que isso não era suficiente para garantir a vitória do chefe do governo provisório. O momento pedia um movimento de rearticulações político-partidárias, do qual Vargas precisava participar. Aproximar-se dos paulistas e garantir o silêncio de sua bancada foram ações fundamentais nessa rearticulação. Diante de tantas concessões, o pedido de Armando de Salles Oliveira para que a bancada paulista deixasse de lado os ajustes de conta tinha propósito definido. O sentimento de humilhação, causado pela derrota em 1932 e posterior exílio, deveria ser esquecido ou contido; não cabia, naquela conjuntura política, rememorar a revolução paulista, pois esse acontecimento representava clara oposição a Vargas e o momento era de composição com o chefe do governo provisório.

A recomposição do passado como memória resulta de um complexo processo de negociação entre presente e passado. $O$ que deve ser permanentemente lembrado atende ao imperativo do agir. A memória conserva as versões dos acontecimentos em meio a uma multidão de pontos de vista. O presente parece ativar apenas parte das interpretações que dão sentido às ações humanas; outras tantas possibilidades interpretativas permanecem inativas, relegadas a um lugar de pouca visibilidade (SANDES, 2009, p. 179).

No caso dos paulistas, durante o processo de reconstitucionalização, que se instaurou no país em 1933 e 1934, o presente exigia a versão do esquecimento. O ano de 1932 não deveria ser reavivado por representar a oposição declarada e armada contra Getúlio Vargas. Com a ascensão de Salles Oliveira à interventoria de São Paulo, indicando adesão ao varguismo, os sentimentos em relação à derrota de 1932 iam sendo mantidos e explicitados apenas na privacidade. Nem mesmo Getúlio Vargas estava certo de sua decisão de composição com o grupo político armandista:

Vou entregar São Paulo aos que fizeram a revolução contra mim. Não pode haver maior demonstração de desprendimento. Será que estou colocando armas nas mãos dos inimigos para que se voltem 
contra mim? Que farão contra mim? Que farão na Constituinte? O futuro dirá, e muito próximo (VARGAS, 1995, p. 231-232).

Temendo não ter dos paulistas a reciprocidade de seu ato de "desprendimento", ao fazer tantas concessões, Vargas manteve certa cautela quanto às suas expectativas em relação à atuação da bancada paulista na Constituinte. Todavia, Armando de Salles Oliveira, fiel ao acordo, orientou a bancada paulista para uma atuação comedida, evitando revanchismos e reavivamentos de ódio contra o chefe do governo provisório. ${ }^{16}$

A atuação de Salles Oliveira no sentido de evitar o reavivamento da memória da Revolução de 1932 foi assunto tratado por Pedro da Costa Rego ${ }^{17}$, respeitado jornalista da época, correspondente diário do jornal carioca Correio da Manhã. Após a Revolução de 1930, Costa Rego defendeu como opção política para o Brasil um projeto liberal. Observador dos movimentos da elite política paulista e do novo interventor de São Paulo, o jornalista esteve atento aos acontecimentos que pudessem comprometer os rumos da Assembleia Nacional Constituinte. Assim, a atuação comedida da bancada paulista foi assunto para seus artigos. O historiador Noé Freire Sandes (2012) pesquisou detidamente os discursos do jornalista a respeito do debate constituinte instalado em 1934, bem como de seus desdobramentos. O historiador relata que, por ocasião da revolução de 1932 e dos conflitos com o chefe do governo provisório, Getúlio Vargas, havia grande expectativa da atuação da bancada paulista durante a Assembleia Nacional Constituinte. As expectativas foram criadas, sobretudo, por parte da oposição. A bancada paulista era portadora da memória da Revolução de 1932, segundo a qual, mesmo derrotada militarmente, se autoproclamou responsável pela instalação da constituinte, impondo fim à imprecisão do governo revolucionário instalado em 1930

\footnotetext{
${ }^{16}$ Um episódio que demarcou a atuação comedida de Armando de Salles Oliveira e de seu grupo político durante a Assembleia Nacional Constituinte, foi a comemoração do aniversário da revolução de 1932, em 9 de julho de 1934, quando a mesma faria dois anos. O jornal O Estado de S. Paulo anunciou grandes comemorações e a Assembleia Nacional Constituinte foi palco para discursos sobre o significado da data. Entretanto, Abreu Sodré, membro do grupo político armandista, na sessão de 10 de julho, discursou conclamando o esquecimento das agruras do passado. $O$ deputado constituinte avaliou que a melhor maneira de homenagear os mortos de 1932 seria o cumprimento da finalidade da campanha revolucionária, ou seja, a constitucionalização do país (OESP, 10/07/1934).

17 Pedro da Costa Rego foi jornalista e político alagoano. Senador por Alagoas, entre os anos de 1929 e 1930 e entre 1935 e 1937. Após a Revolução de 1930, esteve exilado na França. Em 1931, retomou suas atividades no jornal Correio da Manhã, para o qual escrevia desde 1906. Seus escritos eram publicados na sessão que o periódico carioca reservava aos artigos de opinião (SANDES, 2008, p. 43).
} 
(SANDES, 2012). A estreia da bancada paulista nas sessões da constituinte foi marcada por ácida crítica, porém posicionada, de Costa Rego:

O grande e sutil envenenador das frentes únicas, o Sr. Getúlio Vargas, deve estar de parabéns [...] A bancada paulista na Constituinte compareceu ao ato da instalação da assembleia precedida de duas famas, além da fama específica de cada um de seus membros: a primeira era a de seu conselho técnico; a segunda a de seu impenetrável silêncio. [...] Em uma fase como esta, quando todo homem público tem sempre uma declaração a fazer a imprensa, e quando o ilustre general Góes Monteiro, contrariando o conceito de Thiers sobre a mudez dos exércitos, é o campeão reconhecido e indiscutível dos colóquios com jornalistas, o silêncio daquela bancada era o índice de grandes cogitações.

[...]

A brilhante bancada paulista abominava a política. O que ela queria, isto sim, era uma Constituição. Nada, pois de assuntos à margem, embora pertinentes ao objeto da convocação da assembleia. Uma boa constituiçãozinha, seguida de uma aprovaçãozinha dos atos do governo provisório, encerrada por uma eleiçãozinha do Sr. Getúlio Vargas (Correio da Manhã, 01/12/1933, p. 2).

Costa Rego entendeu a atuação da bancada paulista como o resultado de um arranjo, um compromisso firmado com Getúlio Vargas. Este seria o estrategista que, com muita astúcia, minou a relação do acordo firmado entre Partido Republicano Paulista e Partido Democrático, selada com a Frente Única por São Paulo Unido e, posteriormente, com a Chapa Única, que elegeu maioria de deputados constituintes. Na crônica A pesca do Pirarucu, o jornalista fez questão de nomear "as vítimas" das estratégias do chefe do Governo Provisório. Comparou as artimanhas de um habilidoso pescador do peixe amazônico com a capacidade de convencimento e atração exercida por Getúlio Vargas. Exausto de tanto resistir, o animal cede, morde a isca do anzol do pescador. O pescador, ao praticar o movimento incessante de recolher e relançar a linha, com a ísca, conduz o peixe entre "a liberdade ilusória e o aprisionamento". O colunista usa tal metáfora para mostrar as práticas sub-reptícias de anulação ou cooptação dos políticos da oposição. Segundo Sandes:

Ora, não é senão uma pesca de pirarucu o que o Sr. Getúlio Vargas faz, no desdobramento das crises da Revolução. Os homens que ele quer submeter, anular ou proscrever são primeiramente arpoados. Correm. Ao fim da linha, o Ditador suavemente os chama. Embora resistindo, eles voltam, presos no arpão. O Sr. Getúlio Vargas largaos mais uma vez, e só os larga para que voltem, até que, 
extenuados, Ihe possa aplicar o macete. Quem quiser melhores informações sobre o assunto pode dirigir-se aos Srs. Borges de Medeiros, João Neves da Fontoura, Maurício Cardoso, Lindolfo Color, Batista Lusardo, Barros Cassal, Francisco Campos, Adolfo Bergamini, Leite de Castro, Dulcidio Cardoso, José Maria Whithaker, Laudo de Camargo, Waldomiro Lima, João Alberto e outros pirarucus de antigas pescarias. Os da pescaria de agora falarão depois... (Correio da Manhã, 12/01/1934, p. 2).

O silêncio dos paulistas, identificado pelo jornalista como "índice de grandes cogitações", deixava de ser um enigma, revelando-se visivelmente como resultado de um arranjo ou, quem sabe, uma "pescaria". Difícil era saber a quem, desta vez, caberia o papel de pescador. O jornal Correio da Manhã, representante da oposição, decepcionou-se com a atuação da bancada paulista, espécie de guardiã da memória da Revolução de 1932, avaliando que esta havia selado acordo de manter silêncio com o chefe do Governo Provisório em troca de uma reles e "bela constituiçãozinha e de uma eleiçãozinha do Sr. Getúlio Vargas". Os artigos publicados nesse mesmo jornal também expressavam a sua indignação com a falta de clareza quanto ao posicionamento político do grupo de Armando de Salles Oliveira, de quem se esperava a firmeza por ser considerado da oposição. Agravava essa desconfiança a composição de dois ministérios pelos paulistas, ${ }^{18}$ o que engrossava os motivos de crítica ao interventor. Este, ao mesmo tempo que ganhava influência nas decisões nacionais, tornava-se cada vez mais alvo de críticas da imprensa oposicionista, perdendo, aos olhos desta, o prestígio que o passado Ihe conferira. Armando tornouse assim alvo para os políticos da oposição que enfrentavam as agruras de uma guerra em defesa do constitucionalismo e contra Getúlio Vargas.

Para a imprensa oposicionista, não era possível um paulista aproximar-se de Getúlio Vargas, o principal responsável pela perda de autonomia de São Paulo. Afinal, tratava-se justamente de um político que traiu as ideias da revolução de 1930 e principalmente que derrotou os paulistas em 1932. A participação de São Paulo em dois ministérios do governo Vargas acirrou sem dúvida os ânimos oposicionistas, intensificando a luta da oposição contra a aliança estabelecida entre o governo constitucional e o grupo paulista armandista. ${ }^{19}$ Não por acaso, O Correio da Manhã

\footnotetext{
${ }^{18}$ Foi concedido a José Carlos Macedo Soares e a Vicente Ráo, membros do grupo político armandista, as pastas da Justiça e dos Negócios Extrangeiros, respectivamente.

${ }^{19}$ Em São Paulo, o jornal O Correio Paulistano, representante do PRP, passou a reproduzir os artigos publicados por Costa Rego no Correio da Manhã.
} 
denuciava: "Os políticos paulistas penderam de vez para o lado do governo sob a batuta de Armando de Salles Oliveira" (SANDES, 2008, p. 54). Entretanto, é, no mínimo, curioso, o modo benevolente como Costa Rego tratava Armando de Salles Oliveira e seu grupo político, ao defini-los como ingênuos, sugerindo que eles fossem apenas o peixe na história do acordo. Afinal, não seriam também pescadores? Se a aproximação entre Getúlio Vargas e a elite política armandista foi uma espécie de arranjo, há que se levar em consideração que ambas as partes possuíam seus próprios interesses a serem defendidos e negociados; provavelmente foram ambos, e concomitantemente, peixes e pescadores.

Prova disso é a insatisfação de Getúlio Vargas com o resultado da Assembleia Nacional Constituinte de 1934, que estreou provocando seus receios e ressalvas no que diz respeito ao seu conteúdo. Além da insatisfação com a atuação da bancada paulista, apesar das inúmeras denúncias por parte da oposição acerca de seu estratégico silêncio, foi justamente esse silêncio que incomodou Vargas. Com efeito, no dia 16 de julho, data da promulgação da Constituição, o presidente registrou em seu diário o sentimento de insatisfação que o atravessara: "Afinal, chegou esse dia. Entre festas e demonstrações de regozijo, foi promulgada a nova Constituição. Parece-me que ela será mais um entrave do que uma fórmula de ação" (VARGAS, 1995, p. 307). A insatisfação de Vargas não era infundada, na nova carta constitucional venceu o princípio federalista, assegurando a importância da autonômia dos estados, um entrave por certo às pretensões centralizadoras do presidente. Ficou decidido ainda que a primeira eleição presidencial após a promulgação da Constituição seria indireta, através dos votos dos membros da Assembleia Nacional Constituinte, critério que facilitava, já que Vargas foi eleito com 175 votos contra 59 de Borges de Medeiros, candidato da oposição. ${ }^{20}$

No debate sucessório que precedeu às eleições organizadas pela nova Carta Constitucional de 1934, Getúlio Vargas barganhou sua permanência no poder, promovendo articulações e utilizando os recursos políticos de que dispunha. Naquele momento, um aspecto importante para sua vitória foi o fato de ter conseguido assegurar apoio entre os interventores anteriormente indicados por ele

${ }^{20}$ Os outros candidatos receberam apenas 14 votos, distribuídos entre eles: Góes Monteiro, com 4 votos, Protógenes Guimarães, com 2, seguidos de Raúl Fernandes, Artur Bernardes, Plínio Salgado, Antônio Carlos Ribeiro de Andrada, Afrânio de Melo Franco, Firmino Paim Filho, Levi Carneiro e Oscar Weinschenck, todos com apenas 1 voto (VARGAS, 1995). 
para presidir o governo dos estados. Entre eles, estavam Flores da Cunha, do Rio Grande do Sul, Juracy Magalhães, da Bahia, e Carlos Lima Cavalcante, do Pernambuco. Houve também o necessário compromisso com Góes Monteiro, então Ministro da Guerra do governo provisório instalado em 1930, alvo da oposição das bancadas que apoiavam a eleição de Getúlio Vargas como presidente constitucional. Suspeitava-se de uma conspiração com o envolvimento daquele general, com o propósito de impedir que Vargas permanecesse no poder:

\begin{abstract}
Dois interventores - Flores da Cunha, do Rio Grande do Sul, e Juracy Magalhães, da Bahia - informam Vargas dos progressos conspiratórios e do indubitável envolvimento de Góes Monteiro. Em ambos os casos, a opinião é de que se torna necessária uma ação enérgica e imediata em todo o país, de forma que tais articulações sejam contidas. Flores da Cunha, particularmente, chega a enviar a Vargas o nome de todos os chefes de regiões militares que, segundo ele, eram favoráveis à ditadura militar ou à eleição de Góes Monteiro. O clima político de tensão atinge tais níveis que, em meados de abril, de Minas, Bahia e Pernambuco haverem confirmado seu compromisso com a candidatura Vargas, esse mesmo Interventor afirma-se pronto a declarar pela imprensa sua disposição em sustentar, "mesmo que pelas armas", o nome de seu candidato. (GOMES, 2007, p. 66-67).
\end{abstract}

O compromisso firmado com os interventores foi fundamental também para manter Vargas informado das ações dos políticos durante o processo constituinte, inclusas as conspirações tecidas e formadas para afastá-lo da presidência. Assim, no caso de Góes Monteiro, mantê-lo no cargo de Ministro da Guerra durante todo o debate da sucessão presidencial foi tática engenhosa, já que possibilitava assegurar seu comprometimento com a eleição constitucional de Vargas e operava 0 esvaziamento de uma relação de confronto entre os dois. Vargas conduziu as articulações políticas de modo legal, sob as regras republicanas do debate constituinte, mas com habilidade política para esvaziar o discurso daqueles que queriam impedir sua candidatura.

Apesar de ter saído vitorioso das eleições na Assembleia Nacional Constituinte, Vargas sentiu a falta de apoio da bancada paulista, por ter cedido às exigências do grupo. Em conversa com Armando de Salles Oliveira, após o resultado das eleições, Vargas queixou-se de que os esforços por reconciliação apenas estavam sendo cumpridos por parte de seu governo. 
Logo após o resultado final da eleição afluiu ao Guanabara grande número de deputados, ministros e vários amigos que vieram cumprimentar-me. [...] O último com quem conversei foi o interventor de São Paulo. Chegou quando eu assistia, no próprio palácio, a uma sessão de cinema. Terminada esta, retiramo-nos para a sala de despacho. Entrando na matéria do dia, ele ponderou-me que a atitude a que a bancada fora levada, por proposta do deputado Cincinato Braga, não tinha maior importância, porque eles sabiam que não poderiam vencer e, em consciência, pensavam que o meu nome era a melhor solução. Pensava que eu deveria organizar um governo prestigiado pelo apoio de todo o país. Respondi-lhe que este era o meu desejo, não tinha ressentimentos nem má-vontade em se tratando de servir ao interesse do país. Havia dado as maiores provas do meu desejo de aproximar-me de São Paulo, de ter a sua colaboração, mas que a bancada paulista, esquiva, vacilante, falando quase sempre aos compromissos que assumia nas coordenações havidas durante a discussão da Constituinte, não inspirava confiança. Finalmente, sua atitude, combinando-se com elementos da oposição para votar no dr. Borges de Medeiros, demonstrava a persistência de um espírito de hostilidade que eu via com pesar, e que nada poderia fazer sem que partisse deles um gesto de pacificação. Ele concordou inteiramente e prometeu intervir nesse sentido (VARGAS, 1995, p. 307-308).

Podemos observar, portanto, que, apesar de dada como vitoriosa, no momento da instalação da Constituinte, a eleição de Vargas foi porém um processo que dependeu de densas articulações políticas, gerando apreensão por parte do chefe do Governo Provisório. No caso de São Paulo, apesar dos gestos de aproximações de Vargas e de seus esforços em vistas à pacificação, traduzidos em concessões, nomeações e acordos, não se estabeleceu um clima de estabilidade nas relações entre eles. Havia um clima de incerteza no que diz respeito às atitudes tomadas pelos paulistas. Apoiar Vargas como presidente constitucional do país foi motivo de maior desentendimento entre os grupos políticos paulistas, e entre eles e o próprio Vargas. Segundo Castro Gomes:

As eleições presidenciais de 1934 são, desta forma, um episódio politicamente denso e ilustrativo do grau de instabilidade política em que vivia o país e do tipo de confronto que o agitava, tanto na esfera legal da Constituinte quanto na esfera extralegal das conspirações civis e militares. Até os dias finais de funcionamento da Assembleia, Vargas tem que manobrar e utilizar todos os recursos políticos de que dispõe. (GOMES, 2007, p. 69-70). 


\subsubsection{Da interventoria ao governo constitucional. Os três pilares do projeto político armandista colocados em prática. São Paulo deve ser vitrine para o Brasil}

Como já assinalado, a indicação de Armando de Salles Oliveira foi resultado da posição que a Chapa Única por São Paulo Unido conquistou no cenário nacional com a ocupação das 17 cadeiras constituintes. Diante disso, não havia por que estranhar a afinada atuação de um com o outro. Entretanto, é importante perceber que, no decorrer do jogo político, Salles Oliveira e seu grupo político defenderam posicionamento autônomo, evidenciado, por exemplo, na proposta de formação do Partido Constitucionalista. Sua criação não deixou, porém, de ser um gesto de aproximação de Getúlio Vargas, que não se opôs a ideia de um novo partido político em São Paulo, até para dividir a oposição. Uma vez que enfraquecer possíveis alianças entre as principais forças políticas paulistas, como, por exemplo, com o Partido Republicano Paulista (PRP), era algo que interessava a Getúlio Vargas. A fundação do Partido Constitucionalista (PC) provocou com efeito nova cisão dentro do PRP, que perdeu alguns de seus importantes membros para a nova agremiação, gerando desacordos dentro da Chapa Única. ${ }^{21}$ O Governo Provisório avaliou favoravelmente tal iniciativa, certo de que a divisão seria vantajosa no futuro. Afinal, interessava a Getúlio Vargas que a elite política paulista estivesse enfraquecida por divisões e disputas e não unida em torno de um ideal comum: a recuperação de uma posição de centralidade de São Paulo no cenário político nacional.

Sob aquela lógica, em fevereiro de 1934 foi publicado no jornal O Estado de S. Paulo o manifesto de fundação do Partido Constitucionalista, que se apresentaria formalmente no dia primeiro do mês seguinte. Nesse manifesto, enfatiza-se a força simbólica presente na própria denominação do partido e o empenho do seu grupo fundador na luta pela reconstitucionalização do país. São Paulo, de acordo com o manifesto, exigia uma poderosa comunhão política, onde se juntariam sob a mesma disciplina, "os que se empenham no seu engrandecimento e na continuidade do espírito liberal de sua gente" (OESP, 28/02/1934, p. 12). A nova agremiação política foi gerida no interior da cisão ocorrida no Partido Democrático que se extinguiu ao

\footnotetext{
${ }^{21}$ A Chapa Única por São Paulo Unido irá se desfazer após a fundação do Partido Constitucionalista e os principais partidos políticos paulistas irão se enfrentar nas eleições para Assembleia Estadual Constituinte, ainda em 1934.
} 
incorporar-se ao novo partido. Alguns dos importantes membros do Partido Democrático auxiliaram Armando de Salles Oliveira na fundação do novo partido, dentre eles, os políticos Waldemar Ferreira, Paulo Nogueira Filho, Prudente de Morais Neto, Henrique Bayma, Cezário Coimbra, Abreu Sodré, Carlos de Moraes Andrade, Aureliano Leite, Pedro Ferraz do Amaral, Henrique de Sousa Queiroz, Marcos Mélega, bem como o grupo político do jornal O Estado de S. Paulo, liderado por Júlio de Mesquita Filho (PRADO, 1986). O Partido Democrático justificou sua dissolução, deixando claro que o Brasil, naquele momento, não mais precisava de agremiações estaduais, mas de algo maior, que defendesse os interesses nacionais.

Significativamente, em discurso de oficialização do Partido Constitucionalista, que teve a cidade de Piracicaba como palco, Salles Oliveira explicitou sua posição acerca da necessidade de se praticar uma "política alta", formando um novo partido político que atendesse às demandas não apenas de São Paulo, mas também do Brasil. Com o novo partido falava-se não só em interesses estaduais, mas em atender às demandas nacionais:

É tempo de inaugurar em São Paulo uma política alta, uma política que se baseie na probidade integral, de espírito e de coração, e no culto sistemático da verdade. Um partido político que nasce como o Partido Constitucionalista, com o propósito de realizar uma ação renovadora eficaz, tem o dever de esclarecer e guiar corajosamente a opinião pública, evitando a preocupação de lisonjear-lhe as paixões e de segui-la por caminhos errados. A demagogia obscurece a verdade, desorienta os espíritos, divide a nação e estimula a desordem. Não há pior inimigo a combater do que ela, no momento em que o Brasil tem como anseio máximo o restabelecimento da disciplina em todas as suas classes. Reação espontânea e consciente contra os erros do passado, libertado de todos os preconceitos e sofismas, sensível às grandes transformações renovadoras que se produzem por toda parte, com as suas raízes mais robustas mergulhadas nas mais sãs tradições da terra paulista - vosso partido só não reconquistará se o não quiser para São Paulo o seu desempenho de condutor da nação. Depois do triunfo, tereis de continuar a velar sem esmorecimento para que ele não se perca e fique assegurado dentro do Brasil o lugar de São Paulo, não pelas imposições opressoras, mas pela escolha voluntária de todos, rendidos enfim à grandeza de sua civilização e ao esplendor de suas virtudes cívicas. Uma evidência se imporá desde logo ao vosso espírito: no caminho daquele alto ideal, os passos paulistas terão de ser dados com os olhos voltados para todo o país. Porque ou São Paulo compreende as necessidades nacionais ou terá de renunciar a hegemonia política (OLIVEIRA, 2002, p. 52-53). 
Ao fazer referência às causas nacionais que São Paulo deveria abraçar e defender, Armando de Salles Oliveira reafirmava as pretensões da centralidade de São Paulo, defendidas pelo seu partido, cujo propósito é o de alçar e consagrar São Paulo como a unidade da federação que representaria a nação, graças ao seu poder econômico e sua força política.

Segundo o pesquisador Plínio de Abreu Ramos (1980), Armando de Salles Oliveira precisava de um novo partido para fortalecer suas bases políticas em São Paulo e assim poder candidatar-se à presidência da República no futuro próximo; ou seja, já em 1937. Assim, logo após assumir a interventoria, o grupo paulista armandista já visava ter uma posição de alcance nacional no cenário político brasileiro.

Disposto a candidatar-se à Presidência da República e atrair, para sua indicação, o apoio de Vargas, sob forma de reconciliação de São Paulo com o governo federal, Armando precisava fortalecer suas bases políticas no próprio Estado que governava, para dar ao país a impressão de um poderio eleitoral incontestado. Sabia que não poderia contar com a adesão do Partido Republicano, mas não desprezava a convicção de que, através de uma máquina administrativa poderosa, como a de São Paulo, pudesse arrebatar para uma nova agremiação, que não fosse o Partido Democrático, evidentemente, prestigiosas facções perrepistas muito mais interessadas em harmonizar-se com o poder do que cultivar antigas tradições do tempo da propaganda ( p. 168).

Aquele autor ainda destaca que Armando de Salles Oliveira não escolheu por acaso a cidade de Piracicaba para discursar sobre as origens do partido político que fundara. Afinal, era a cidade natal de Prudente de Morais, paulista, fundador do Partido Republicano e o primeiro presidente civil da República. Além disso, sua candidatura provocara a primeira dissidência do Partido Republicano Paulista. Sobre a fundação do Partido Constitucionalista e sua capacidade de receber membros de todos grupos políticos, Salles Oliveira ressaltou que:

Longe de ser uma reação contra 30, a revolução de 1932 repusera o país na corrente das aspirações populares que naquele ano o tinham arrastado à luta das armas. [...] Como síntese das aspirações que as duas revoluções defenderam, formou-se o Partido Constitucionalista. Para ele, entraram não só os homens que tinham ajudado a luta contra a prepotência da nossa antiga política; não só os homens mais novos, que eram voluntários das trincheiras; não só os homens que pertenceram ao velho Partido Republicano, que nele tinham tentado uma ação renovadora, e muitos dos quais também se filiavam à antiga liga dos patriotas paulistas; mas ainda homens que 
nunca tinham penetrado na política e que, aceitando a advertência dos acontecimentos de 1932, passaram a colaborar nos negócios políticos (apud RAMOS, 1980, p. 169).

Com base nesse discurso de Armando de Salles Oliveira, é possível afirmar que o Partido Constitucionalista não visava substituir a legenda já desgastada do Partido Democrático. O partido surgia da necessidade de uma nova força política, capaz de fundir o programa liberal de $1930 \mathrm{com}$ as reivindicações constitucionalistas de 1932: "uma síntese das aspirações que as duas revoluções defenderam", como o próprio político sublinhou.

Com efeito, aquele desgaste era visível, pois em 24 de fevereiro de 1934, Benedito Montenegro anunciou o fim das atividades da Federação dos Voluntários e Valdemar Ferreira promoveu, juntamente com Morais Barros, a extinção do Partido Democrático. O Partido Republicano Paulista também sofreu as consequências da fundação de uma nova agremiação política em São Paulo, perdendo parte de seu quadro para o Partido Constitucionalista. ${ }^{22} \mathrm{~A}$ partir de então estava criado o Partido Constitucionalista, cujo documento básico, lançado na ocasião, consistiu no Manifesto aos Paulistas, publicado no jornal O Estado de S. Paulo em 28 de fevereiro de 1934. O Manifesto projetava e anunciava o papel que São Paulo iria desempenhar dali por diante na vida política brasileira, sendo que sua primeira etapa já havia sido conquistada: a escolha de Armando de Salles Oliveira para interventoria de São Paulo.

As vitórias eleitorais de Armando de Salles Oliveira à frente do Partido Constitucionalista são bem significativas do crescimento e força que a agremiação rapidamente alcançou. As eleições legislativas foram realizadas em todo país em 14 de outubro de 1934 e nelas o Partido Constitucionalista obteve 219.471 votos contra 160.709 dados ao Partido Republicano Paulista. ${ }^{23}$ Para a Câmara Federal foram

\footnotetext{
22 De acordo com Plínio de Abreu Ramos, o Partido Republicano Paulista foi fortemente atingido pelo "tufão armandista". Para o Partido Constitucionalista, transferiram-se políticos proeminentes como Abelardo Vergueiro César, Alarico Caiuby, Alfredo Cecílio Lopes, Antônio Pereira Lima, Aristides Silveira Fonseca, Machado Florense, Brasílio Machado Neto, Cândido Mota Filho, Carlos Reis de Magalhães, Cory Gomes de Amorim, Dagoberto Sales, Francisco Vieira, Generoso Alves de Siqueira, Joaquim Pennino, Luís Pisa Sobrinho, Benedito Serpa, Renato Pais Barros, Samuel Junqueira Franco, Zózimo de Abreu e, mais tarde, Alcântara Machado, líder da Chapa Única na Constituinte.

${ }^{23}$ As eleições legislativas foram palco de uma acirrada disputa entre Partido Constitucionalista e Partido Republicano Paulista.
} 
eleitos 22 deputados constitucionalistas, ${ }^{24}$ e no caso dos deputados estaduais, foram eleitos 34 membros do Partido Constitucionalista. ${ }^{25}$ Já os perrepistas, embora mais antigos no cenário político paylista, foram em menor número para a Assembleia Legislativa Estadual, 22 deputados. ${ }^{26}$ Os resultados indicam que o Partido Constitucionalista, apesar de recém fundado, conseguiu resultados expressivos, finalmente acabando com a hegemonia do PRP nas eleições.

A Assembleia Estadual foi instalada no dia 8 de abril de 1935, e logo depois, em 10 de abril, foram realizadas eleições diretas para o governo do Estado e para o Senado Federal. Novamente, os resultados foram favoráveis ao Partido Constitucionalista: Armando de Salles Oliveira foi eleito governador constitucional com 36 votos, derrotando o candidato perrepista, Altino Arantes, que obteve 22 votos. Para ocupar as vagas do Senado, o Partido Constitucionalista foi mais uma vez o vitorioso, ao eleger Paulo de Morais Barros, que obteve 33 votos, e Alcântara Machado, com 36 votos. Os candidatos do Partido Republicano Paulista foram Márcio Tavares, que obteve 22 votos, e Oscar Rodrigues Alves, com 20 votos.

O propósito de fortalecimento e consolidação do Partido Constitucionalista encontrou ressonância junto à sociedade, traduzida nos expressivos resultados

\footnotetext{
24 São eles: Abelardo Vergueiro César, Antônio Carlos de Abreu Sodré, Antônio Castilho de Alcântara Machado, Antônio Pereira Lima, Aureliano Leite, Carlos de Morais Andrade, Carlota Pereira de Queirós, Francisco Alves dos Santos Filho, Francisco Oscar Penteado Stevenson, Horácio Lafer, João Alves de Meira Júnior, João Rodrigues de Miranda Júnior, Joaquim Sampaio Vidal, José Joaquim Cardoso de Melo Neto, Justo Rangel Mendes de Morais, Luís Barbosa da Gama Cerqueira, Luis de Toledo Pisa Sobrinho, Paulo Nogueira Filho, Ranulfo Pinheiro Lima, Teotônio Monteiro de Barros e Valdemar Ferreira. Já o Partido Republicano Paulista elegeu 12 deputados federais: Álvaro Teixeira Pinto Filho, Antônio Bias da Costa Bueno, Cid de Castro Prado, Cincinato Braga, Félix Bulcão Ribas, Heitor Macedo Bittencourt, Henrique Jorge Guedes, João Batista Gomes Ferraz, José Alvez Palma, Laerte Setúbal, Manuel Hipólito Rego e Roberto Moreira. O resultado das eleições de 14 de outubro de 1934 foi publicado no jornal O Estado de S. Paulo, no dia 31 de janeiro de 1935, de onde retiramos os números e nomes aqui apresentados. (HAYASHI, 2010, p. 54).

${ }^{25}$ São eles: Antônio Carlos Pacheco e Silva, Aristides Macedo Filho, Benedito Montenegro, Bento de Abreu Sampaio Vidal, Cândido Mota Filho, Carlos de Morais Barros, Carlos de Souza Nazaré, Cássio da Costa Vidigal, Celso Torquato Junqueira, Clóvis de Paula Ribeiro, Cory Gomes de Amorim, Dante Delmanto, Elias Machado de Almeida, Enersto de Morais Leme, Eugênio de Toledo Artigas, Francisco Mesquita, Francisco Vieira, Henrique Neves Lefévre, Henrique Bayma, Joaquim Celidônio Gomes dos Reis Filho, José Augusto de Sousa e Silva, Laerte Assunção, Manfedro Antônio da Costa, Maria Teresa Nogueira de Azevedo, Mário Pinto Serva, Oscar Cintra Godinho, Paulo Duarte, Renato Bueno Neto, Romão Gomes, Sílvio de Andrade Coutinho, Tiago Marzagão, Valdomiro Silveira e Valetim Gentil. (HAYASHI, 2010, p. 54).

${ }^{26}$ São eles: Ademar de Barros, Alberto Americano, Alfredo Ellis Júnior, Carlos Cirilo Júnior, Décio Pereira de Queirós Teles, Diógenes Augusto Ribeiro de Lima, Epaminondas Lobo, Frederico José Márquez, Inocêncio Seráfico de Assis Carvalho, Ismael Torres Guilherme Cristiano, João Batista Ferreira, José Almeida Sampaio Filho, José Bastos Cruz, José Moura Resende, Padre Luís Fernandes de Abreu, Luís Pereira de Campos Vergueiro, Manuel Carlos de Siqueira, Mariano de Oliveira Wendell, Miguel Arcanjo de Abreu Lima Pereira Coutinho, Oscar Thompson, Sebastião de Magalhães Medeiros e Tarcísio Leopoldo Silva.
} 
eleitorais. Essa ação política exigiu o envolvimento pessoal de Salles Oliveira nas campanhas eleitorais municipais, realizadas no dia 15 de março de 1936 . Os resultados também foram significativos: o Partido Constitucionalista obteve 248.336 votos, elegendo 173 prefeitos e 1095 vereadores.

Armando de Salles Oliveira saiu fortalecido e reconhecido como principal liderança na política paulista com os resultados das eleições, confirmando acertada sua a decisão de criar um novo partido político. O Partido Constitucionalista localizava-se no espectro liberal do campo político, cujos representantes eram quadros das elites treinadas para o exercício do governo de São Paulo e do Brasil. Segundo Oliveiros Ferreira (2007), foi justamente essa sua insistência em fazer do partido instrumento de excelência para resolução dos problemas do país que assegurou a Salles Oliveira distinguir-se dos demais quadros políticos do legislativo e do executivo no período de 1930-1937. Na perspectiva armandista, a sustentação da democracia dependeria da força programática e do fortalecimento dos partidos políticos. A fundação do Partido Constitucionalista atenderia a tal perspectiva. No discurso proferido em Guaratinguetá, Armando de Salles Oliveira apresentou seu pensamento sobre a existência dos partidos políticos:

O que se impunha entre nós não eram, entretanto, problemas de administração, mas o político. É impossível realizar uma administração sã e eficaz se ela não se apóia nas ideias e na ação de um vigoroso partido. Sendo difícil a execução de um largo programa de administração dentro de um curto período de governo, a continuidade dessa execução subordina-se à constância de ação do partido. $O$ impressionante desequilíbrio dos últimos governos constitucionais de São Paulo nasceu da decadência do Partido Republicano, que abdicará a sua autoridade nas mãos dos chefes do Executivo.

(...)

Fundar um grande partido, que, filiado diretamente à nossa revolução, reunisse não somente os grupos partidários como os homens que, isentos de saudade do passado, desejassem dar a São Paulo uma forte política de reconstrução e de fé. Foi o que desde logo compreenderam diversos homens de responsabilidade na política paulista. Surgiu o partido de renovação, feito para São Paulo, feito para o Brasil, feito para ação (OLIVEIRA, 2002, p. 209-10).

Identificam-se três pilares no projeto político de poder do grupo armandista: além da criação do Partido Constitucionalista, outras duas ações seriam implementadas na interventoria de Salles Oliveira: a que investia na educação e na 
cultura, com a fundação da Universidade de São Paulo, e a que priorizava a eficiência administrativa na governança da prefeitura, sob a gestão de Fábio Prado.

Não é nosso objetivo detalhar cada um desses pilares, que exigiriam um estudo mais aprofundado, como é o caso da universidade, mas apresenta-los como parte das ideias desenvolvidas pelo grupo político em questão. À Universidade de São Paulo cabia formar as elites dirigentes e intelectuais de São Paulo e do Brasil, bem como seus quadros técnicos e profissionais. Ainda mais, formaria elites dirigentes "saídas dos mesmos bancos" e formadas "pelas mesmas ideias" (OLIVEIRA, 2002). Nesse sentido, em 25 de janeiro do ano de 1934, data do aniversário de São Paulo, Salles Oliveira assinou o decreto-lei instituindo a primeira universidade "cientificamente estruturada" do país (SILVA, 1980, p. 117). Estavam também envolvidos na fundação da universidade os amigos e companheiros de partido e de propósitos políticos, Paulo Duarte e Júlio de Mesquita Filho.

\subsubsection{A Universidade de São Paulo e a Prefeitura de Fábio Prado}

Segundo Irene de Arruda Cardoso (1982), "a Universidade tem a função primordial, dentro deste projeto, de ser a instituição que irá reproduzir esta elite depositária da razão, destinada a conduzir a nacionalidade” (p. 92). A criação da universidade foi produto de um projeto político e ideológico, onde as elites oriundas dela deveriam conduzir a política no país. Para Fabiane Oliveira (2016), foi construída uma memória sobre a Universidade de São Paulo, incorporada pela historiografia, que afirma Armando de Salles Oliveira como fundamental para o projeto de criação da universidade. Mesmo depois da morte de Armando de Salles Oliveira e fim do grupo armandista, os membros ligados àquele grupo e ao jornal $O$ Estado de S. Paulo, continuaram a vincular o nome de Salles Oliveira e sua importância para construção da USP. Nesse sentido, Paulo Duarte colaborou para consolidação dessa memória, ao narrar detalhadamente as iniciativas envolvidas na criação da universidade. Foi organizada uma comissão para discutir sua formação, composta por Henrique da Rocha Lima, Fernando Azevedo, Vicente Ráo, F.G.

Fonseca Teles, André Dreyfus e Teodoro Ramos, que partiram para a Europa em busca de elementos jovens para comporem a universidade. Dentre os primeiros 
professores estrangeiros, estavam: Paul Arbousse Bastide, Whatagin, Breslau, Rhein Arbousse, De Fiore, Honorato, Levi-Strauss, Mombeing, Roger Bastide, Bonzon, Ernst ,Marcus, Perroult e Magriet. A Faculdade de Filosofia recebeu maior atenção, pois, sob a perspectiva de Armando de Salles Oliveira, compreendia a cabeça da universidade. Ela ensinaria o estudante a pensar e "quem não aprender a pensar, não pode fazer parte de uma universidade" (DUARTE, 1976, p. 68). Para Duarte, a universidade era idealização de Julio de Mesquita Filho. Todavia, ainda que idealizada por ele, a criação da mesma só foi viável graças ao fato de Armando de Salles Oliveira estar no poder na ocasião. Afinal, a universidade também era parte do seu projeto político.

Antônio Carlos Pacheco e Silva, deputado da bancada paulista de 1934, declarou ter convivido com Armando de Salles Oliveira e publicou a biografia do interventor, em 1966, com o apoio de Assis Chateaubriand. Num dos capítulos, intitulado "Foi este o homem que fundou a Universidade de São Paulo", Pacheco e Silva revela alguns pensamentos de Armando acerca do porque de se criar a universidade:

É que tinha ele bem presente em seu espírito atilado e na sua visão clarividente, o que iria representar a Universidade de São Paulo na vida paulista e brasileira, como um verdadeiro cérebro, integrando a ciência e a técnica, para forjar uma elite intelectual capaz de orientar todas as classes sociais (SILVA, 1980, p. 118).

No discurso proferido em Araras, em 22 de abril de 1934, Armando de Salles Oliveira enfocou o tópico Administração e Cultura, ressaltando qual papel exercia a universidade na política do país:

Ao lado destas questões de pura administração, cuidou o governo da questão máxima, a da cultura, e criou a Universidade de São Paulo. Com a Universidade se implantará a vigorosa estrutura cultural em que assenta a independência dos grandes povos. Com a Universidade adquiriremos, pelo conhecimento que nos vai de nossos recursos e de nossas necessidades, a exata consciência de nós mesmos. Com a Universidade, prepararemos as classes dirigentes sem as quais não será possível enfrentar os vastos problemas de um grande Estado moderno e, abrindo o leito para as novas correntes de pensamento, daremos àqueles problemas a solução verdadeiramente nacional (OLIVEIRA, 2002, p. 70). 
A Universidade seria, então, instrumento do governo, formando quadros, preparando as classes dirigentes capazes de "enfrentar os vastos problemas de um grande Estado moderno", capazes de propor soluções verdadeiramente nacionais para os problemas do país. No governo de Salles Oliveira, as elites políticas paulistas procuraram se reorganizar. O novo interventor teve um papel decisivo nesse processo, reconstruindo o aparelho administrativo paulista, destroçado após anos de instabilidade política. Mas sua principal obra foi no campo da cultura com a criação da Universidade de São Paulo (USP), que em pouco tempo se tornaria responsável pela formação de uma nova elite político-intelectual destinada a influir no futuro do estado e do país.

Humberto Campos, cronista que Armando de Salles Oliveira admirava, revelou em crônica um diálogo que manteve com o interventor sobre a Universidade:

A Universidade cria as elites e a crise brasileira não é popular, mas das classes superiores, não é das massas, mas dos que devem dirigi-las e não se acham preparados nem conjugados para thes imprimir direção... São Paulo compreendeu isso e vai iniciar a grande marcha. A Universidade que estamos fundando, servida por especialistas eminentes, vai formar e disciplinar para a vida publica, para as necessidades de sua política e de sua ciência, a primeira geração homogênea, depois da República. Saídos dos mesmos bancos, orientados pelas mesmas idéias, sob influxo dos mesmos líderes do pensamento humano, as vindouras gerações paulistas constituirão legiões serenas e esclarecidas que se oporão, em conjunto, a anarquia mental que ameaça a destruir a civilização em nossa terra. (SILVA, 1980, p. 120).

Ainda em agosto de 1934, Salles Oliveira deu início à construção do terceiro pilar de seu projeto político, ao indicar, como interventor, Fábio Prado para prefeito da cidade de São Paulo ${ }^{27}$. A indicação desse empresário e político que, além de ter participado ativamente da Revolução de 1932, onde lutou pela autonomia de São Paulo, revelava-se um administrador moderno, ligado à indústria, aos negócios e também à criação da universidade, gerou expectativas de novos tempos entre os paulistas. É durante a gestão de Fábio Prado como prefeito de São Paulo que a

\footnotetext{
${ }^{27}$ Fábio da Silva Prado nasceu em São Paulo, membro de uma tradicional família de fazendeiros do café, os Silva Prado. Diplomou-se em engenharia industrial na Escola Politécnica de Liège, Bélgica. Posteriormente, tornou-se presidente de importantes companhias como, por exemplo, a Companhia das Terras Norte do Paraná, Cotonifício Rodolfo Crespi, de propriedade do seu sogro e a Companhia Mojiana de Estradas de Ferro. Foi ainda diretor do Banco Mercantil de São Paulo e da Federação de Indústrias do Estado de São Paulo. Fábio Prado ingressou na vida política como vereador na Câmara Municipal de São Paulo, assumindo a prefeitura em 1934, durante a interventoria de Armando de Salles Oliveira. (SAMPAIO, 1999).
} 
política cultural, um dos tripés do projeto do grupo armandista, foi desenvolvida. Fábio Prado convidou Paulo Duarte para ser seu chefe de gabinete, dando liberdade para que o ex-revolucionário executasse seus projetos culturais na cidade de São Paulo. Paulo Duarte fundou e dirigiu, ao lado de Mário de Andrade, o Departamento de Cultura de São Paulo, espaço institucional onde desenvolveram alguns projetos culturais. $^{28}$ Observasse assim que, ao lado do Partido Constitucionalista, da administração da prefeitura de São Paulo, a política cultural formava ao lado da Universidade de São Paulo o terceiro pilar de sustentação do projeto político armandista. Juntos, esses três pilares ancoravam o projeto responsável pelo desafio de pensar o Brasil e propor soluções científicas e modernas para seus problemas.

O controle do governo por esta parte da elite paulista concretizava o sonho discutido por eles nos jantares regados a ideias, mencionados por Paulo Duarte, que a princípio se opôs ao envolvimento de Armando de Salles Oliveira com Getúlio. Para o memorialista, aproximar-se de Getúlio Vargas, a quem ele nomeava "diabo", era colocar em risco a causa revolucionária. Maria Ruth Amaral de Sampaio descreveu a administração da capital paulista a partir de uma entrevista concedida ao jornal O Estado de São Paulo por Fábio Prado, em março de 1936. Na entrevista, que durou sete dias, e que a autora considerou uma das fontes mais consistentes acerca da atuação de Fábio Prado, este concedeu longos depoimentos acerca de suas realizações, com as obras já concluídas, outras sendo realizadas e também os projetos que ainda estavam no plano das ideias, mas que já se tornavam públicos (SAMPAIO, 1999).

Paulo Duarte, chamado pelo próprio Fábio Prado para ser seu chefe de gabinete, narrou minuciosamente seu trabalho ao lado do prefeito na capital. As metas estabelecidas pelo prefeito e seu parceiro de administração consistiam em: reorganizar o sistema administrativo municipal, abalado por anos de instabilidade política; regulamentar o funcionalismo público, estabelecendo concursos com regras claras; reorganizar as finanças públicas, investindo parte delas em cultura. A prefeitura passava por um momento de crise financeira, mas, com a reorganização

\footnotetext{
${ }^{28}$ Segundo o historiador Daniel Faria (2013), "para Mário de Andrade, os anos 1920 foram marcados pelo delírio modernista que, em seu espírito destruidor, teria preparado anseio revolucionário que desembocara nos acontecimentos de 1930." (p. 112). A ânsia por um projeto cultural que propusesse mudanças, como era a ideia de Paulo Duarte, fez com que Mario de Andrade aceitasse de imediato o convite do amigo. A escolha da Mário de Andrade por Paulo Duarte para dirigir um departamento de cultura ao seu lado revela o desejo de identificar o projeto político cultural do grupo armandista com o aspecto do moderno, do novo.
} 
da tributação dos impostos, Paulo Duarte lembrou que eles poderiam aplicar o que era lei, ou seja, $10 \%$ dos impostos arrecadados seriam destinados à realização de obras culturais. O forte da administração de Fábio Prado foram as obras de urbanização na cidade e a criação de parques infantis, relatada como a primeira obra de cunho social realizada pela prefeitura e também embrião do que seria, posteriormente, o Departamento de Cultura (DUARTE, 1976). Segundo relato de Maria Ruth Sampaio, eram feitas pesquisas com os frequentadores dos parques infantis, com o objetivo de levantar dados acerca de moléstias, hábitos alimentares e tradições familiares. Havia um intercâmbio entre a Universidade de São Paulo e os parques criados pela administração de Fábio Prado. Enquanto a Universidade formava os profissionais capazes de atender aos parques, estes contribuíam como espaço para pesquisas (SAMPAIO, 1999).

No que se refere à administração de Fábio Prado, destaca-se, em particular, a novidade da criação do Departamento de Cultura. Anos antes de Fábio Prado entrar para prefeitura e indicar Paulo Duarte como seu assessor, eles se reuniam juntamente com um grupo de escritores e jornalistas que escreviam para o Diário Nacional, órgão de imprensa do Partido Democrático. Nessas reuniões nasceu o sonho de um projeto para pesquisar e produzir conhecimento sobre as coisas brasileiras e sonhos brasileiros, temática e objetos tidos até então como possibilidades remotas, sem a atuação direta no governo. O momento era agora, com Armando de Salles Oliveira no governo seria possível a concretização daqueles sonhos, daquelas ideias debatidas naquelas reuniões. A criação da Universidade de São Paulo e a gestão de Fábio Prado, com a criação do Departamento de Cultura, mantinham um clima de euforia cultural na cidade. O projeto era esse e estava sendo executado, conforme sonhou Paulo Duarte. Afinal, eles eram naquele momento os homens do governo.

Antes de terminar o ano de 1934, já dançava dentro do meu espírito o programa cultural que podíamos levar a cabo. Nunca saíram da minha cabeça, as nossas conversas do apartamento da Avenida São João, dos tempos históricos de formação do Partido Democrático e do Diário Nacional. Conversei, nas suas melhores horas, com Fábio sobre a organização de um grande Departamento de pequenas pesquisas históricas, sociais, que reunisse teatro, cinema, bibliotecas, música, divertimentos públicos, rádio e mesmo turismo (DUARTE, 1976, p. 168). 
Entende-se que essas ideias só puderam ser operacionalizadas porque havia uma política de governo para São Paulo definida e implementada por Salles Oliveira, interventor nomeado por Vargas. Essa posição exigiu construir uma aliança com Getúlio Vargas. No projeto armandista priorizava-se a necessidade de o país modernizar-se por meio de um sistema de educação, por uma política de cultura e partidos políticos ferreamente disciplinados (OLIVEIROS, 2007). Como local da experiência piloto do projeto político pensado para São Paulo e o Brasil, foi escolhida a cidade de São Paulo. Esta, depois da atuação do grupo armandista, se tornou então vitrine do governo paulista. No discurso do próprio interventor:

Ao brasileiro que, num momento de dúvida, quiser revigorar a confiança no futuro do Brasil, darei com convicção o conselho de empregar alguns dias numa visita à terra paulista. Banhado pelo ar de nossas culturas e de nossos campos, ele voltará de São Paulo com um otimismo que nunca mais o abandonará (OLIVEIRA, 2002, p. 66).

O projeto político dos constitucionalistas teve continuidade entre os anos de 1935 e 1937, período marcado pelas realizações de Armando de Salles Oliveira à frente do governo de São Paulo, que traziam em seu bojo o projeto de ambição maior, o de suceder Getúlio Vargas na presidência do país. O Partido Constitucionalista iniciou suas atividades com plena força e dinamicidade. Embora Salles Oliveira desejasse impressionar o restante do país com a demonstração de sua força política em São Paulo, ele foi contido e detido por Getúlio Vargas. Foi justamente no contexto dos debates acerca das eleições presidenciais que se observa um novo reordenamento do quadro político nacional e o visível afastamento entre a elite política armandista e Getúlio Vargas.

\subsection{A nova "depuração das elites"}

Novamente, foi o tema das eleições presidenciais que exigiu de Getúlio Vargas um enorme esforço de articulação com os governadores dos estados e outras forças políticas da época. Mais uma vez, os paulistas serão motivo forte de preocupação por parte de Vargas. De acordo com a carta Constitucional promulgada em 1934, a próxima eleição presidencial, que elegeria o sucessor de Getúlio Vargas, 
ocorreria em janeiro de 1938, sendo que o novo presidente eleito assumiria o cargo em maio daquele ano. Getúlio Vargas, a princípio, buscará articulação com os interventores que o ajudaram a eleger-se presidente constitucional em 1934. No entanto, em 1936, já como governadores, eleitos pelas Assembleias Estaduais Constituintes, ocorridas em julho de 1935, aqueles mesmos interventores irão optar pelo confronto e não pelo compromisso com Getúlio Vargas. A opção se deu como forma de garantir que a sucessão do presidente acontecesse em tempo previsto pela Constituição de 1934. Getúlio Vargas, a princípio, tentará prorrogar seu mandato presidencial via legal, sob a alegação de que as ideias comunistas ameaçavam a estabilidade política do país naquele momento. Uma eleição presidencial poderia acirrar os ânimos, abrindo caminho para o crescimento das forças comunistas. Diante da resistência de alguns governadores, o compromisso foi feito com a cúpula militar. A resistência por parte de governadores como Flores da Cunha e Juracy Magalhães em apoiar a proposta de Vargas causou surpresa no Presidente, que não se surpreendeu tão somente com a recusa de Armando de Salles Oliveira e seu grupo político. Como Vargas mesmo reconheceu em seu diário, o comportamento esperado do grupo paulista era sempre imprevisível.

Entender a impossibilidade de Vargas firmar todos os compromissos necessários à prorrogação de seu mandato e a opção pelo confronto por parte de algumas elites estaduais exigiu-nos atentar para a política dos anos de 1935 e 1936. Ao observarmos esses anos, rejeitamos duas ideias frequentes na historiografia que predominou até os anos 1980: a de que toda ação das elites políticas paulistas visava à recuperação de cargos de poder perdidos com a Revolução de 1930; e a de que o golpe de novembro de 1937 era uma consequência prevista e lógica da Revolução de 1930. Com efeito, entre os anos de 1935-1936, como resultado da ação dos atores políticos do período, acrescidos agora dos grupos de esquerda e de direita, desenhou-se um quadro político favorável tanto à instalação da campanha eleitoral do grupo armandista à sucessão presidencial, quanto ao golpe de novembro de 1937. 


\subsubsection{5: o tema dos "extremismos" redireciona o espectro do campo político}

A partir de 1933, novas agremiações políticas irão surgir, revelando o descontentamento não só da classe operária, mas também de antigas lideranças, atuantes na revolução de 1930, como os Tenentistas, que agora procuravam novas frentes para se integrar. ${ }^{29}$ Entre essas novas agremiações estava a Aliança Nacional Libertadora, fundada em março de 1935, sob a liderança de Luís Carlos Prestes ${ }^{30}$. A agremiação reunia não só socialistas e comunistas, mas também dissidentes de grupos liberais, insatisfeitos com o caminho que a política no país havia tomado a partir da revolução de 1930. Muitos desses dissidentes, inclusive, haviam lutado ao lado da Aliança Liberal durante a revolução. Desde sua fundação, a quantidade de adesões à ANL chamava a atenção e seu crescimento fez com que Getúlio Vargas a colocasse na ilegalidade, poucos meses depois de sua fundação. Chama a atenção o rápido crescimento da $\mathrm{ANL}^{31}$, que em apenas três meses contava com cerca de 1500 núcleos distritais e municipais e cerca de 100 mil filiados, metade desses concentrados no Rio de Janeiro.

Esse crescimento de adesões com uma proposta alternativa às agremiações partidárias tradicionais não era uma exclusividade da ANL. Outra agremiação extremista que ganhou força nesse período foi a Ação Integralista Brasileira, que também exibia cerca de 100 mil aderentes. ${ }^{32}$ Segundo Dulce Pandolfi (2003), tanto a AIB quanto a ANL possuíam um programa bem definido e uma organização impecável, o que fazia com que mobilizassem adesões por todo território nacional. Entretanto, a maneira como ambas as agremiações se portavam diante do governo

\footnotetext{
${ }^{29}$ Segundo Edgar Carone (1974), no ano de 1933 "surgem os Partidos Trabalhistas de São Paulo, Aliança Socialista e Partido Socialista Brasileiro, mostrando uma grande inquietude política." (p. 58), existiam ainda descontentes, organizados individualmente ou em sindicatos, com o intuito de pressionar o governo vigente.

${ }^{30}$ Em 1924, Luís Carlos Prestes abandonou a carreira no Exército para liderar uma guerrilha através do interior do país, conhecida como Coluna Miguel Costa-Prestes. Foi o início de um percurso de luta armada e política, que rendeu ao revolucionário prisões e exílios. Prestes se converteu ao marxismo no início dos anos 1930. Depois de uma estada na União Soviética, a convite do governo daquele país, em 1934, tornou-se membro do Partido Comunista Brasileiro (PCB). A partir de então, começou a articular a queda do governo Vargas (AARÃO REIS, 2014).

${ }^{31}$ Estima-se que a agremiação recebia até 1600 novas adesões diariamente, em claro sinal do aumento do descontentamento com o governo vigente (CARONE, 1965).

32 Os militares da AIB eram atraídos para suas fileiras devido à propaganda anticomunista, difundida principalmente pela imprensa oficial da organização, e também pelas críticas ao liberalismo, que, no entender da organização, havia fracassado como projeto político para nação. Ancorado nesse discurso, o movimento cresceu rapidamente, e espalhou-se por todo país, estabelecendo núcleos em inúmeras cidades brasileiras (VICTOR, 2012).
} 
Vargas, estabelecido a partir de 1930, era bem diferente. A AIB chegou a apoiar Getúlio Vargas e a barganhar com o presidente, buscando inserção no poder. Já a ANL, desde seu início, fez oposição ao governo vigente, tramando sua derrocada. Foi justamente esse crescimento rápido das agremiações que as tornaram suspeitas, representadas como ameaça ao governo central e à unidade de nação. Nesse quadro político, destacava-se a Aliança Nacional Libertadora, cuja ação abriu espaço e/ou pretexto para que a Constituição de 1934 fosse alterada, provocando rearticulação das elites políticas estaduais. Como bem avalia Ângela de Castro Gomes:

A importância destes dois movimentos (ANL e AIB) ideologicamente formados e organizacionalmente definidos como propostas políticas de "esquerda" e de "direita" - é crucial para o curso dos acontecimentos políticos do pós-1934. Importa ressaltar o verdadeiro caos jurídico que o enfrentamento desses movimentos trouxe ao país. A partir das primeiras manifestações políticas de pressão destas novas forças articuladas, desencadeou-se uma violenta ofensiva governamental em duas frentes essenciais: a repressão policial, dirigida especialmente à classe operária, mas que acabaria se expandindo e abarcando jornalistas, intelectuais e mesmo parlamentares, e a legislação excepcional, que a partir de abril de 1935, com a Lei de Segurança Nacional, fortaleceria os poderes do Presidente da República tão cuidadosamente controlados pela Carta de 1934 (GOMES, 2007, p. 91).

Em meio a um contexto de crescente radicalização política ${ }^{33}$ e de polarização entre movimentos ideologicamente localizados à esquerda e à direita do campo político, em abril de 1935, o Congresso irá sancionará a Lei de Segurança Nacional, proporcionando ao país o clima de retorno ao regime de exceção. A Lei de Segurança Nacional, cujo objetivo era o de punir de modo rigoroso crimes contra a segurança do Estado (ABREU, 2001), ${ }^{34}$ fortaleceria os poderes do presidente da República. Houve resistência apenas por parte de alguns pequenos grupos de Deputados, de modo que a lei foi aprovada sem maiores resistências.

Em novembro de 1935, com a ação crescente dos comunistas, Getúlio Vargas arranjou motivos para estabelecer um maior cerceamento das liberdades políticas no país, promovendo uma maior radicalização na Lei de Segurança

\footnotetext{
${ }^{33}$ A medida que a Aliança Nacional Libertadora e a Ação Integralista cresciam, aumentavam os conflitos entre comunistas e integralistas, contribuindo para gerar um clima de tensão política no país (ABREU, 2001).

${ }^{34}$ A íntegra da Lei de Segurança Nacional, Lei $n .^{\circ} 38$, de 04/04/1935, pode ser encontrada em CARONE, Edgar. $A$ Nova República (1930-1937), Editora Difel, 1974.
} 
Nacional. A razão teria sido o retorno de Luís Carlos Prestes da União Soviética, onde encontrava-se exilado. Ele retornou ao Brasil em 1935, clandestinamente e ao lado de alguns companheiros, como Olga Benário. O intuito, conforme já mencionamos, era o de organizar um levante armado para depor Getúlio Vargas do poder e instaurar no país um governo revolucionário. O levante, que ficou conhecido como Intentona Comunista, foi brutalmente reprimido pela polícia de Getúlio Vargas. ${ }^{35}$ É importante observar que, embora a ação da ANL não tenha tido o êxito esperado por Luís Carlos Prestes, contribuiu de forma decisiva para uma reorganização das forças políticas naquele momento. Segundo Dulce Pandolfi (1999), a Intentona comunista provocou mais um momento de "depuração das elites" políticas, contribuindo de forma decisiva para colocar em pauta a discussão sobre o debate sucessório.

O clima de instabilidade política aumentou com a atuação das esquerdas, traduzidas no levante que tentou derrubar o governo. Motivo de sobra para radicalização do regime, com o Congresso aprovando emendas à Constituição de 1934, como a decretação do "estado de guerra", e dando assim ao Executivo poderes quase que ilimitados para reprimir qualquer ameaça à ordem. Em setembro de 1936, Vargas instituiu o Tribunal de Segurança Nacional, para julgar os participantes do levante. ${ }^{36}$ A Intentona serviu como pretexto para a liberdade fosse cerceada. Como avalia Ferreira:

Apanhado de surpresa pelo movimento de 1935 no Nordeste e no Rio de Janeiro, o governo reagiu propondo emendas à Constituição de 1934, uma, prevendo a decretação do "estado de guerra", outra, cuidando dos militares. [...] A Constituição de 1934 não previa a figura do "estado de guerra"; apenas do "estado de sítio". Aquela nova figura, pela emenda aprovada pelo Congresso, era de perversidade única, se assim podemos dizer, mas denotava que seus autores tinham um acendrado espírito jurídico positivo: no estado de sítio, suspender-se-iam estas e aquelas garantias individuais, especificadas no artigo da Constituição sobre o estado de sítio; no "estado de guerra", declarar-se-iam quais as garantias constitucionais que não estavam suspensas. O "estado de guerra" será decretado em 1936 depois da Intentona e, de novo, em 1937,

\footnotetext{
${ }^{35}$ Luís Carlos Prestes, na condição de chefe da ANL e mentor do levante de agosto de 1935, foi enviado para prisão, onde permaneceu cerca de dez anos. Alguns anos depois, já durante o regime do Estado Novo, Olga Benário, esposa de Prestes, que se encontrava grávida do revolucionário, foi enviada ao regime de Hitler, na Alemanha, vindo a morrer em um campo de concentração.

${ }^{36}$ O Tribunal de exceção era ativado sempre que o país se encontrava sob estado de guerra. Sua função era processar e julgar aqueles que promovessem alguma ameaça às instituições militares, políticas ou sociais do país. Estima-se que, entre 1936 e 1937, o Tribunal julgou e condenou cerca de 1.420 pessoas (ABREU, 2001).
} 
no auge da agitação consequente à crise com o Rio Grande do Sul, à campanha sucessória e à descoberta do plano Cohen." (FERREIRA, 2007, p. 149).

Tanto a Lei de Segurança Nacional como o Tribunal de Segurança Nacional foram iniciativas que contribuíram de forma decisiva para que, pouco mais a frente, Vargas pudesse elaborar e executar o golpe de novembro de 1937, sem maiores resistências. Não se pode ignorar o fundamental papel desempenhado pela imprensa na aprovação de tais medidas, e também em sua legitimação. Foi através da imprensa que Getúlio Vargas acabou por ganhar respaldo social para cercear as liberdades políticas. Nesse sentido, o grupo político de Armando de Salles Oliveira contribuiu para que tais medidas fossem tomadas e efetivadas. Discursos pronunciados por Armando de Salles Oliveira, alertando a população sobre o "perigo vermelho" e elogiando o poder central por suas ações de repressão, aplainaram o terreno, amenizando o impacto das medidas de exceção junto à sociedade, não importando que as mesmas atingissem a própria imprensa. Tal posição de Salles de Oliveira pesou na avaliação posterior do grupo a respeito de seus passos no passado. $\mathrm{O}$ apoio às medidas de exceção de Vargas teve, é claro, um custo para os paulistas, que pouco tempo antes se uniram para promover guerra armada para pedir pela Constituição. $\mathrm{Na}$ avaliação de Carone:

Contra a frente única popular, forma-se a frente única oligárquica. Liderado por São Paulo, com o beneplácito do governo federal e das camadas conservadoras, cria-se um instrumento legal para abafar todo protesto. A Lei de Segurança Nacional é a arma contra as manifestações operárias e da oposição, mas será, no futuro, a arma usada por Getúlio Vargas para derrubar certas alas da oligarquia, lideradas por São Paulo. (CARONE, 1974, p. 58)

Não por acaso, o Partido Republicano Paulista criticou imediatamente a postura do grupo armandista, pois este, ao apoiar as medidas para cercear a liberdade propostas por Vargas, inclusive no que diz respeito à liberdade de imprensa, estabelecia uma aproximação perigosa com o projeto autoritário varguista, afastando-se do projeto liberal. Como ressalta Cohen,

O PRP aponta ainda os momentos em que, em nome da estabilidade, o governo estadual age exatamente com os mesmos instrumentos da ditadura getulista. E o proclamado liberalismo do PC é posto em dúvida pelo PRP. É o caso da censura, estabelecida através do estado de guerra decretado no início de 1936. Sua 
aplicação ficava a cargo dos governos estaduais, mas os deputados perrepistas mostram que, mais do que zelar pela segurança nacional, o governo aplica a censura para calar as forças de oposição e agir livremente (COHEN, 1997, p. 213)

Como justificavam os perrepistas, teriam os paulistas também aderido a uma espécie de autoritarismo, ao acatarem a proposta varguista como única alternativa possível? Na avaliação de Cohen,

Segundo as regras do estado de guerra, os assuntos proibidos de publicação referiam-se a notícias sobre a autoridade constituída; notícias tendenciosas ou alarmantes; notícias sobre censura e por fim telegramas e notícias sem origem determinada. (COHEN, 1997, p. 213).

O estado de sítio foi prorrogado sucessivamente até meados de 1937, por mais de uma vez com o apoio do grupo armandista. Todavia, quando as eleições presidenciais se aproximaram, o Congresso, pressionado por alguns setores das elites políticas estaduais, dentre estes os armandistas, irá negar um novo pedido de prorrogação do estado de sítio (GOMES, 2007). A radicalização dos grupos descontentes com o governo vigente, especialmente na ação dos partidários de Luís Carlos Prestes e da Aliança Nacional Libertadora, teve peso na aprovação de algumas mudanças na Constituição por Vargas e estas serão uteis daquele momento em diante. O acirramento da oposição, criou condições para que Getúlio Vargas colocasse em questão a prorrogação dos mandatos, com o adiamento do debate sucessório.

Também é a partir da discussão a respeito da necessidade de conter os extremismos que surge o tema da "crise". A criação da crise, segundo Ilka Stern Cohen (1997) foi bastante propícia para o grupo político armandista se projetar como alternativa política não só para São Paulo, mas para todo o país, apoiado na candidatura de Salles de Oliveira à sucessão presidencial de Getúlio Vargas. Segundo aquela historiadora:

É nessas circunstâncias que se pode compreender o tema da "crise" como uma presença constante no discurso da imprensa. Vários autores observam a importância desse tema no pensamento político; a constatação de uma crise é o ponto de partida para a ação transformadora. O procedimento consiste na elaboração de um diagnóstico do presente e projeção para o futuro, qualificando o passado ou como róseo - no caso dos que pretendem retomar o 
caminho do ponto em que se desviou - ou como temeroso, no caso daqueles que prometem um futuro diferente. Ao apontar um momento de crise, o discurso político propõe simultaneamente a possibilidade de um retorno ao momento anterior, do qual ela está ausente, como também a perspectiva de um futuro baseado na sua superação. (COHEN, 1997, p. 11).

A "crise" gerada pelo clima de instabilidade política possibilitou pensar alguns outros caminhos naquele momento. No caso de Getúlio Vargas, a princípio, investiu-se na prorrogação dos mandatos e, posteriormente, no endurecimento do regime com a elaboração de proposta de golpe de Estado, justificada por aquele clima. No caso dos paulistas, a proposta era lançar a candidatura de Armando de Salles Oliveira como única alternativa possível. A ameaça da crise, o temor do perigo dos extremismos partidários sustentavam um movimento de redefinição dos rumos políticos do país, tanto por parte do governo Vargas como de São Paulo. Como ressalta Cohen:

Assim é possível compreender o tratamento dado à questão dos "extremismos", tema construído pacientemente a partir de 1935, e que se por um lado tem uma relação evidente com a questão da Aliança Nacional Libertadora, por outro deixa perceber a preocupação em alertar a opinião pública para o crescimento descontrolado do "perigo verde", tão capaz de por em risco a estabilidade social quanto o "perigo vermelho". É assim que se pode compreender a organização, em São Paulo, de duas entidades que têm por objetivo dominar os campos de que são alvo o movimento integralista: a massa trabalhadora e a ação cultural. Diante dos dois perigos (o "verde" e o "vermelho"), desenvolve-se em São Paulo uma tentativa de redefinição dos rumos políticos a partir de uma sociedade organizada em torno de novos princípios. (COHEN, 1997, p. 190-191).

Os Paulistas participam do jogo político disseminando a ideia de que o país vivia uma crise política, ameaçado pelo extremismo de comunistas da ANL e de integralistas da AIB. Entretanto, no momento de dar início ao debate sucessório, conscientizam-se que precisam enfrentar outra força, bem mais poderosa que aquela: Getúlio Vargas e sua movimentação no sentido de prorrogar o mandato presidencial. 


\section{3. "Achegas para uma história não escrita". A candidatura de Armando de Salles Oliveira e a defesa da Constituição \\ Sob o tópico "Achegas para uma história não escrita", Vivaldo Coaracy,} membro do grupo armandista e correspondente do jornal O Estado de S. Paulo, no Rio de Janeiro, registrou em suas memórias os acontecimentos do período que antecedeu o golpe de novembro de 1937. Segundo o jornalista, quando Armando de Salles Oliveira foi indicado interventor de São Paulo, enviou Vivaldo Coaracy à sucursal do jornal O Estado de S. Paulo no Rio de Janeiro, com o intuito de ter próximo ao Catete um homem de sua confiança, que o mantivesse informado da política palaciana.

Desde então, o jornalista permaneceu no Rio de Janeiro na condição de correspondente do OESP, até o golpe de novembro de 1937. Além do trabalho no jornal, Coaracy enviava regularmente cartas pessoais para Salles Oliveira, que aquele denominava de "breves relatórios da situação política", vista a partir do Rio de Janeiro. ${ }^{37}$

Apenas quero deixar, à guisa de depoimento, o registro de um punhado de fatos, aparentemente desconexos, sobre os quais posso dar meu testemunho pessoal. São achegas que talvez contribuam para esclarecer ocorrências relativas à questão mais importante dessa época, a sucessão presidencial, que conduziu ao golpe nefando de 10 de novembro de 1937, quando pereceram as instituições democráticas. (COARACY, 1961, p. 273).

Com tal intuito, o jornalista relembra que Paulo Nogueira Filho, - deputado por São Paulo, pelo Partido Constitucionalista -, ainda no início de 1936, pouco depois da Intentona Comunista, começou a apregoar, no Palácio dos Tiradentes, o nome de Armando de Salles Oliveira como forte candidato à sucessão presidencial. Intrigado com tal possibilidade, Coaracy questionou Salles Oliveira, já que, na condição de amigo íntimo, segundo o relato do jornalista, não ouvira até então do governador nada a respeito dessa candidatura:

Era de manhã, antes do almoço. Conversávamos no quarto de vestir. D. Raquel, a esposa de Armando, sentada num pequeno sofá

\footnotetext{
${ }^{37}$ O jornalista Vivaldo Coaracy teve importante papel na campanha eleitoral de Armando de Salles Oliveira. Situado no Rio de Janeiro, Coaracy trocou diversas cartas com o então candidato à presidência da República, fazendo espécies de relatórios da situação política do país, sobretudo da situação da sucessão presidencial, a partir do Rio de Janeiro. Paulo Duarte ficou de posse dessas cartas, anexando-as ao seu arquivo político, que nós apresentaremos no último capítulo desta tese.
} 
situado entre duas portas, e na poltrona próxima, eu. Em mangas de camisa, de pé, diante do armário aberto, Armando escolhia, meticulosamente a gravata que usaria, quando o interpelei:

- Armando, vou-lhe perguntar uma coisa. Não é por interesse político, nem por mera bisbilhotice. Mas, para orientação do meu serviço, preciso de saber. Você pretende se candidatar à sucessão de Getúlio?

Erguendo as mãos ao alto, num gesto expressivo, D. Raquel protestou:

- Deus nos livre!

Armando, a sorrir, voltou-se para mim:

_ Você me acha com jeito de pegar em rabo de foguete?... - Depois, tornando-se sério, expôs: - Olhe Coaracy: o programa que quero realizar em São Paulo é tão vasto que não sei se quatro anos de governo chegarão para tudo. Ao fim destes quatro anos, haverá uma vaga no Senado, a do Paulo de Morais e Barros. Pretendo me candidatar a essa vaga, isso sim. No senado, então, irei fazer política no plano federal. Aí veremos. - E voltando a exame de suas gravatas acrescentou: - Eu ainda estou moço. Posso esperar.

Não sei precisar, mas essa conversa teria sido entre abril e maio de 1936. (COARACY, 1961, p. 263).

Acerca da construção dessa candidatura, o jornalista relata também que, logo após a deflagração da Intentona Comunista, com os ânimos exaltados, Vicente Ráo, então Ministro da Justiça do Governo $\operatorname{Vargas}^{38}$, foi ao seu encontro e expôs o que pensava ser a melhor opção para situação delicada que o país enfrentava. Falou-lhe sobre as ameaças comunistas e que eram duas as soluções saudáveis para o Brasil naquele momento: a prorrogação dos mandatos e/ou o adiamento do debate sucessório. No relato de Coaracy, que incluiu sua avaliação sobre a situação política daquele momento:

Uma campanha eleitoral, de âmbito extensivo a todo o país, provoca sempre agitação que perturbaria prejudicialmente a marcha serena da administração pública em ocasião em que a solução de múltiplos problemas exigia tranquilidade dos espíritos. Foi esta a alegação invocada para que o Presidente da República recomendasse, com empenho, a protelação para a época mais conveniente do exame de sua sucessão. A época seria posterior a uma certa data de janeiro de

\footnotetext{
${ }^{38}$ Vicente Ráo era paulista e foi Ministro da Justiça do governo Vargas, entre 1934-1937. Sua indicação partiu direto de Armando de Salles Oliveira, ao lado da indicação de José Carlos Macedo Soares para pasta do Ministério do Exterior. Ambas as indicações eram parte da tentativa de reconciliação entre o governo central e a elite política paulista. Na condição de Ministro da Justiça, Vicente Ráo participou da elaboração da Lei de Segurança Nacional (NETO, 2014). Devido seu apoio à ideia de Vargas de prorrogar o mandato presidencial, Vicente Ráo será uma das decepções do grupo político armandista, episódio relatado por Paulo Duarte, em suas memórias.
} 
1937, creio que 3 ou 4, quando, de acordo com a Constituição, estariam incompatibilizados para concorrer como candidatos à presidência da República os governadores dos Estados e os ministros que na referida data se achassem em exercício do cargo. Era evidente que o motivo alegado não passava de simples pretexto e mal disfarçado. O objetivo real era afastar da competição aqueles possíveis concorrentes à sucessão de Getúlio Vargas. (COARACY, 1961, p. 277).

E com razão. O pretexto foi logo apropriado por aqueles que apoiavam Getúlio Vargas e não interessavam em ter concorrentes na sucessão. Assim, naquela ocasião, Vicente Ráo declarou que estava de acordo com a proposta do Presidente: os debates políticos em uma campanha de sucessão presidencial poderiam exaltar ainda mais os ânimos, fragilizando a unidade nacional e abrindo espaço para que ameaças comunistas voltassem a germinar, desta vez, quem sabe, até mesmo poderiam obter sucesso. Segundo o previsto na Constituição, os políticos que pretendiam se candidatar à sucessão presidencial, precisavam se descompatibilizar de seus cargos na Câmara e à frente dos governos dos estados até janeiro de 1937. Nesse sentido, a proposta de Vargas para que o debate sucessório só tivesse início passado os primeiros meses de 1937 era bem sugestiva, uma vez que, desse modo, conseguiria inviabilizar a candidatura dos governadores e demais políticos que estivessem em exercício de seus mandatos.

Para prorrogar os mandatos, Vargas precisava, porém, do apoio de dois terços do Congresso. Um resultado que só seria alcançado com o apoio dos governadores. Getúlio Vargas viu no proclamado clima de crise política e de ameaça comunista o pretexto e a oportunidade de propor uma prorrogação de mandatos via legal, ou seja, alterando a Constituição. Assim, confiando em sua experiência e visão política, Getúlio Vargas viu no atual quadro político daquele momento espaço para consultar alguns governadores, cujo apoio seria fundamental para aprovar a almejada prorrogação de mandatos no Congresso. Entretanto, as investidas de Getúlio Vargas foram frustradas. Os governadores dos Estados da Bahia, São Paulo, Pernambuco e Rio Grande do Sul recusaram a proposta varguista, deixando claro que vetariam qualquer tentativa no sentido de prorrogar 0 mandato presidencial. Apenas Benedito Valadares, governador de Minas Gerais, apoiou o chefe do Executivo. Getúlio Vargas, atuando no sentido de persuadir os chefes de algumas unidades da federação, com encontros políticos com tal propósito. Foi o 
caso, principalmente, dos governadores Juracy Magalhães, da Bahia ${ }^{39}$, Flores da Cunha, do Rio Grande do Sul ${ }^{40}$, e Carlos Lima Cavalcanti ${ }^{41}$, de Pernambuco, contrários à prorrogação. Eram, principalmente, aqueles políticos que, em 1934, diante do debate sucessório na Assembleia Constituinte, estiveram ao lado de Getúlio Vargas, contribuindo para sua eleição constitucional, agora estavam do lado oposto. A política mostrava naquele momento que podia dar muitas voltas.

O caso dos paulistas era, porém, na visão de Vargas, o que mais preocupava. Entre 1933 e 1935, Vargas tinha conseguido negociar alguns acordos com os paulistas do grupo armandista. No entanto, no que diz respeito ao adiamento do debate sucessório, a posição de Armando de Salles Oliveira foi firme, recusandose a colaborar. Pelo contrário, sua posição era a de opor-se à prorrogação. Segundo Vivaldo Coaracy, foi justamente a proposta de prorrogar o mandato presidencial que impulsionou Armando de Salles Oliveira a lançar-se candidato ainda em 1936, frustrando os planos de Vargas continuar no poder, via alteração da Constituição. Segundo o jornalista, as eleições presidenciais marcadas para janeiro de 1938 não eram um objetivo estipulado como ápice de um projeto político de poder. Todavia, diante da proposta de prorrogar o mandato presidencial, o político paulista se sentiu obrigado a proteger a Constituição, abandonando o projeto político para São Paulo em prol de um projeto político mais amplo, para "salvar o país". O posicionamento de Salles de Oliveira pautava-se em três grandes ameaças ao país: a ameaça "vermelha" da ANL, a ameaça "verde" dos integralistas e a ameaça de volta da "ditadura varguista", experimentada entre1930-1934. O termo "ditadura", tão explorado durante a revolução de 1932, passou a compor o vocabulário do grupo

\footnotetext{
${ }^{39}$ Cearense, militar, indicado por Getúlio Vargas para o cargo de interventor do Estado da Bahia, eleito governador constitucional desse mesmo estado nas eleições de 1935, pelo PSD baiano. (Coutinho, Amélia. Dicionário Histórico Biográfico Brasileiro pós 1930. 2a ed. Rio de Janeiro: Ed. FGV, 2001. Acesso em 12/06/2015).

${ }^{40}$ Flores da Cunha pertencia ao mesmo partido político que Getúlio Vargas no Rio Grande do Sul, atuando contra a corrente que lutava pela libertação daquele estado. Foi eleito deputado pelo Ceará e pelo Rio Grande do Sul, eleito senador em 1928 e, após a vitória da revolução de 1930, nomeado interventor e depois eleito governador constitucional do mesmo estado.

${ }^{41}$ Carlos de Lima Cavalcanti foi deputado estadual, interventor e governador constitucional pelo Estado de Pernambuco. Participou da articulação do "Bloco do Norte", em 1931, que defendia a maior atenção do governo federal pelos Estados do Norte e do Nordeste. Após ser eleito governador constitucional do Estado do Pernambuco, Lima Cavalcanti iniciou seu afastamento do poder central, portanto, de Getúlio Vargas, estabelecendo proximidade com Flores da Cunha e Juracy Magalhães, governadores do Rio Grande do Sul e da Bahia, respectivamente. (PANTOJA, Sílvia. Dicionário Histórico Biográfico Brasileiro pós 1930. 2a ed. Rio de Janeiro: Ed. FGV, 2000. Acesso em 11/06/2015).
} 
armandista. Na avaliação de Vivaldo Coaracy, foi justamente para combater tais ameaças que Armando de Salles Oliveira precisou candidatar-se e garantir que a Constituição fosse cumprida. Um gesto de "desprendimento" e "nobreza por parte de Salles de Oliveira na avaliação do jornalista:

Em meados de 1937, durante um almoço em meio a agitada campanha sucessória. A certo ponto, a propósito de não sei mais o que, perguntei a Armando se ele se lembrava de me haver dito, uma vez, em São Paulo, que não pretendia se candidatar a sucessão de Getúlio por ter uma grande obra ainda para realizar como governador. E ele explicou:

_ Eu só me candidatei para evitar que se consumasse o crime infame da prorrogação de mandatos que tiveram a ousadia de vir me propor. (COARACY, 1961, p. 281).

Se em 1935 o inimigo comunista era o inimigo em comum das demais forças políticas, e o posicionamento do grupo armandista foi de defesa das medidas propostas pelo presidente para combater as ameaças comunistas, em 1936, essa aliança desfez-se com a proposta de adiamento do debate sucessório. No pensamento dos democráticos, uma prorrogação de mandatos seria o equivalente ao retorno à ditadura que consideravam ter vivido entre 1930 e 1934 . Recusada a ideia de prorrogar os mandatos, o nome de Armando de Salles Oliveira começou a ser veiculado e discutido. Desta vez, pelo governador do Rio Grande do Sul, Flores da Cunha, uma das mais fortes oposições ao continuísmo de Vargas. Uma vez que a estratégia de articular apoio com antigos parceiros políticos não obteve sucesso, Getúlio Vargas partiu para outra estratégia: a tentativa de esvaziar o debate sucessório.

\subsubsection{O debate sucessório}

O tema do debate sucessório surgiu pela primeira vez nos diários de Getúlio Vargas, vinculado aos comentários públicos feitos por Flores da Cunha a respeito do tema. Segundo Aspásia Camargo (1989), desde a instalação do governo provisório, os gaúchos estavam frustrados com a política centralizadora adotada por Getúlio Vargas. Tal postura não estaria de acordo nem com as práticas tradicionais nem com a plataforma apresentada e defendida pela Aliança Liberal em 1930, em prol da 
qual os gaúchos haviam lutado e colaborado para retirar o paulista Washington Luís do poder. A partir daquele momento, Flores da Cunha se tornou então um forte obstáculo para os planos de Getúlio Vargas, principalmente no que diz respeito ao seu plano de adiar o debate sucessório e de desencorajar a possível candidatura de Armando de Salles Oliveira à sucessão presidencial. Afinal, Flores da Cunha respaldava-se em uma grande força política, representada pelos seus partidários e pelo Estado que governava, uma grande força militar. ${ }^{42}$ Vargas sabia que num possível confronto entre o Executivo e algumas unidades da federação, a exemplo do que foi a guerra de 1932, não seria prudente ter o Rio Grande do Sul, fortalecido político e militarmente, do lado oposto. Era preciso neutralizá-lo.

A princípio, em seus registros pessoais, Getúlio Vargas afirmava não ter interesse em ocupar a presidência da República por mais tempo que o estabelecido constitucionalmente. É o que registra, com visível sinal de aborrecimento com o governador Flores da Cunha, em razão de uma denúncia, feita no início de 1936, de que o chefe do governo central queria mesmo era se perpetuar no poder. Segundo o registrado em seu diário:

O horizonte político enche-se de boatos. Os jornais anunciam a vinda do Maurício e a recomposição do Ministério. O Flores espalha que meu desejo é permanecer no poder [além] dos quatro anos da eleição, mas que ele se oporá. Até agora, porém, eu ignorava o motivo desses zelos democráticos do general, porque sempre esteve nos meus propósitos, findo o quatriênio, transmitir pacificamente o governo ao meu substituto e ir descansar. Ontem, porém, tive a explicação desses boatos.

O Sr. Herbert Moses, que me veio falar sobre os impostos que recaem sobre o papel da imprensa, abordou-me sobre a minha reeleição mediante uma reforma da Constituição. Manifestei-me contrário a essa idéia, sem nenhuma vacilação. Depois, o Luís Aranha comunicou-me que o deputado Bias Fortes Ihe dissera que ia sugerir ao Luzardo que falasse ao Maurício, a fim de que a oposição formulasse na Câmara um projeto de prorrogação do mandato. Levei o assunto à hulha, não lhe dando maior importância (VARGAS, 16/03/1936, p. 487).

Já em julho, por ocasião do aniversário da morte de João Pessoa, Vargas, ao visitar o túmulo do político, reitera a ideia de que poderá pelo menos descansar

\footnotetext{
42 O Rio Grande do Sul, já em 1932, por ocasião da guerra paulista, fortaleceu seu poderio militar, que desde então não havia sido desmantelado.
} 
assim que concluir o mandato. Ressalta que, como todo governante que encerra seu período, também se tornaria um "vivo morto, como tantos outros que por aí andam":

Sexto aniversário da morte de João Pessoa. À tarde, fui ao cemitério. Estava vazio, apenas algumas pessoas da família junto ao túmulo. Demorei poucos minutos, e começou a juntar-se gente no local. Não se sabia de onde vinha, mas os vivos ainda atraem mais que os mortos, principalmente quando aqueles ainda podem dar, e estes já não fornecem margem a ser explorados. Quando terminar o mandato, serei um vivo morto, como tantos outros que por aí andam. Mas poderei descansar (VARGAS, 26/07/1936, p. 527).

Decidido a ter o controle sobre o processo sucessório, Vargas queixa-se das tramas, conspirações e acordos estabelecidos pelo governador do Rio Grande do Sul, que insistia em trazer à tona o debate sobre a sucessão presidencial, considerado prematuro. É neste momento que surge, pela primeira vez, o nome de Armando de Salles Oliveira como possível candidato à Presidência da República, com apoio de Flores da Cunha:

O Flores continua tramando, conspirando, fazendo acordos. Está com a fobia da sucessão presidencial, quer forçar a discussão este ano, e faz acordos em todos os sentidos - chegou a mandar oferecer apoio ao Armando de Salles para candidatura deste.

$[\ldots]$

Continuam as intrigas políticas. O Flores quase todos os dias vai à Câmara fazer prosélitos, conseguir aliados no sentido de forçar, ainda este ano, a discussão das candidaturas presidenciais. Nesse sentido, mandou o Collor propor ao líder paulista governamental o apoio do Rio Grande à candidatura de Armando de Salles (VARGAS, 27-8/07/1936, p. 528).

Empenhado em fazer oposição a Vargas, Flores da Cunha trama, conspira e insiste no tema da sucessão, costurando acordos em torno de uma possível candidatura de Salles Oliveira. Para tal, comunica ao político paulista a aceitação de sua candidatura por parte do Rio Grande do Sul, justamente a terra de Getúlio Vargas. Já em outubro, a ideia daquele nome como possível candidato presidencial circulava por São Paulo, trazendo desconforto a Vargas:

O João, que ontem esteve na Guanabara conversando comigo, referiu que a candidatura Armando Sales estava apaixonando os paulistas, e que talvez arrastasse a uma situação de luta, gerando a convicção de que eu me opunha ao nome dele e que seria um inimigo de São Paulo. (VARGAS, 02/10/1936, p. 549). 
Enquanto isso, Flores da Cunha continuava seu jogo político, tramando e articulando para forçar a antecipação do debate da sucessão presidencial para desestabilizar o governo Vargas e desalojá-lo do poder. Segundo os registros de Vargas, continuavam "as explorações políticas e os pretextos de que eu preparo minha reeleição, para a mobilização do Flores, quase 15 meses antes da eleição. "Só mesmo um maluco", registrou Vargas (1936, p. 551). Getúlio Vargas resistia em iniciar o debate da sucessão presidencial, que via como precoce. Ele procurava minimizar as tensões da disputa eleitoral, acalmar os ânimos políticos, reafirmando seu desejo de apenas cumprir seu mandato e depois disso "descansar". No entanto, a medida que candidatura de Salles Oliveira ganhava corpo, Getúlio Vargas começou, porém, a se posicionar de modo mais firme sobre a questão.

O discurso proferido por Armando de Salles Oliveira em São José do Rio Pardo, em 18 de outubro de 1936, provocou especial desconforto em Getúlio Vargas. Foi um pronunciamento que incomodou sobremaneira Vargas, por se apresentar como uma espécie de abertura do processo sucessório, com o lançamento da candidatura do político paulista. O discurso de Armando de Salles Oliveira é longo, mas vale a leitura de algumas de suas passagens, pois expressa seu pensamento, expectativas e programa políticos em defesa do princípio da federação como condição básica da unidade do país.

Profundamente arraigadas ao sentimento regional, as províncias brasileiras tentaram várias vezes combater o regime centralizador, que as condenava à estagnação. A queda da monarquia deu-lhes a autonomia política e administrativa a que aspiravam. De asas livres, realizaram em poucos anos um progresso notável. Os índices desse progresso revelam em muitas delas, a começar por São Paulo, uma completa transformação na fisionomia social, econômica e política.

O exercício da autonomia e o incontestável êxito do regime vincaram ainda mais profundamente 0 antigo sentimento das províncias brasileiras, e, depois de quarenta anos de experiência republicana, o princípio da federação como condição básica da unidade do país é a mais viva das realidades nacionais. (OLIVEIRA, 2002).

Salles Oliveira faz veemente defesa do pacto federativo e da autonomia dos Estados, proposta que contrariava os interesses e orientações centralizadoras do governo Vargas. Ao fazer tal defesa, Armando de Salles Oliveira destaca a posição de São Paulo na federação, unidade detentora de forte sentimento regional, sem 
comprometer, porém, a unidade nacional. São Paulo foi representado nesse discurso como Estado próspero, dinâmico e autônomo:

Os sentimentos regionais não são manifestações de orgulho dos Estados mais ricos: existem com igual vigor em todos os pequenos Estados. Não constituem rivalidades que enfraquecem, mas saudáveis emulações que robustecem a nação. Além disso, todos sentem as vantagens do sistema descentralizado que, pondo o poder público em contato direto com as necessidades coletivas, dá maior eficácia à administração, simplifica-a e nela introduz em todas as graduações da hierarquia, a disciplina, a competência e a responsabilidade.

$[\ldots]$

Transferindo em caráter temporário alguns poderes para o governo federal, nenhum golpe o Legislativo poderia dar na autonomia dos Estados. A unidade da nação repousa no equilíbrio do ideal federativo. Nem o enfraquecimento excessivo do governo federal, precursor do desmembramento, nem o fortalecimento excessivo da autoridade central. Esta, fazendo surgir aqui e ali, por falta de equidade na sua ação, o sentimento de revolta contra injustiças econômicas, ou anulando aos poucos os governos dos Estados, acabaria por desvirtuar o pacto federativo.

O Brasil é e quer ser uma federação democrática e não uma democracia imperial. A autoridade do governo central deve ser forte e respeitada, mas formada sobretudo da autoridade dos Estados. (OLIVEIRA, 1937, p. 1-12).

O fortalecimento do sistema republicano federativo, do presidencialismo com autonomia e representatividade dos Estados, assegurado pelo sistema eleitoral, foi tema recorrente nos discursos de Armando de Salles Oliveira. O político destaca a posição de centralidade de São Paulo na experiência republicana, sublinhando a importância dos "sentimentos regionais", comuns aos "Estados mais ricos" e também aos "pequenos Estados", todos eles fundamentais para a unidade do país. Nesse sentido, sentimento regional não atuava como uma ameaça ao país, mas como um complemento, capaz de incentivar a constituição de estados fortes que formariam o país. Vargas, que entendeu o discurso como uma senha para abertura da candidatura do político paulista, registrou o evento em seu diário:

O discurso do Armando de Salles deu lugar a um ensaio de candidatura à Presidência: pedidos de inscrição na Câmara, discursos etc,. [...] O ministro do exterior disse que o discurso do governador de São Paulo era um discurso da época vitoriana, em grande estilo, mas fora de moda. 


\section{$[\ldots]$}

O discurso do Armando de Salles continua explorado pelos politiqueiros, principalmente os da oposição. (VARGAS, 213/10/1936, p. 555).

Armando de Salles Oliveira, em "grande estilo", mas "fora de moda", parecia representar um sério obstáculo a qualquer pretensão continuísta do presidente, principalmente porque explorado pelos políticos da oposição. Assim, não nos parece exagerado destacar a importância decisiva da articulação das elites políticas paulistas que, ao se revelar como força concorrente aos seus planos de continuísmo, mobilizou Getúlio Vargas em direção ao golpe que instaurou o Estado Novo. Uma vez fracassada sua tentativa de articular com os governadores dos estados sua permanência no poder, como ocorreu durante a Constituinte de 1934, Vargas teve que pensar e lançar mão de uma nova estratégia de ação. À medida em que a possibilidade de Salles Oliveira suceder Getúlio Vargas na Presidência da República foi apresentando-se cada vez mais viável, alguns sinais de mudanças no jogo político nacional vão surgindo. Um deles, as mudanças na relação do governo central com os paulistas, bem como no quadro político nacional, em 1937. Como registrou um apreensivo Vargas:

No ambiente político, agita-se a trama da sucessão presidencial. O ministro da Fazenda, regressando de São Paulo, traz a impressão de que o entourage do Armando não pensa senão na candidatura deste. O ministro do Trabalho, regressando do Norte, descobriu o trabalho do Juarez nos estados da Bahia e Pernambuco também pela candidatura de Armando, que se procura agitar no exército

\section{[...]}

Continua o movimento de simpatia em torno da candidatura Armando de Salles. O ministro do trabalho conta-me que seu colega da Justiça informou-o que seria provável a renúncia do governador de São Paulo para disputar sua candidatura.

$[\ldots]$

O panorama político toma um aspecto mais sério: os paulistas começam a apregoar, com arrogância, que ninguém poderá deter a candidatura de Armando, que pretendem humilhar São Paulo, e que Armando deixará o governo breve. Essa arrogância se apóia no caudilhismo de Flores. O ministro da Justiça manobra, o perrepismo vacila, o ministro da Guerra contemporiza com a situação do Rio Grande, sabotando o General Góis e deixando-se influenciar por elementos carcomidos. 
São Paulo e Rio Grande unidos, Santa Catarina e Paraná absorvidos, o Exército minado, a situação é séria. Devo passar à ofensiva. (VARGAS, 5-14/11/1936, p. 557-560).

A situação política temida por Getúlio Vargas consistia justamente na construção de uma aliança entre São Paulo, Rio Grande do Sul, Pernambuco e Bahia, cujas forças políticas de oposição a Vargas poderiam aglutinar-se em torno da candidatura de Armando de Salles Oliveira. "Devo passar à ofensiva" foi a decisão de Vargas diante do crescente "movimento de simpatia pela candidatura de Armando de Salles", alimentada pelas articulações e conspirações de Flores da Cunha. O "orgulho" e a "arrogância" dos paulistas, apoiada no caudilhismo do governador gaúcho, é tema a que Vargas volta muitas vezes em seu diário. Esta situação representava, em sua opinião, uma das origens dos problemas nacionais desde 1931. São argumentos que serão usados na conjuntura do golpe, que justificariam sua decisão de uma ação ofensiva e drástica. Trata-se de condições históricas que nos levam a defender que o golpe do Estado Novo possivelmente tenha começado a ser cogitado menos em função da ação dos comunistas do que da ação da oposição paulista unida em torno da candidatura Armando de Salles Oliveira. Significativamente, foi em meio a esse movimento de alianças entre seus opositores que Vargas decidiu "passar à ofensiva". Essa reação resultou no golpe do Estado Novo. Era preciso deter esse movimento. No registro de Vargas, este assinala que:

Continuam os boatos políticos, principalmente em torno da renúncia do governador de São Paulo, único que ainda não respondeu meu telegrama-circular sobre o apoio à prorrogação do estado de guerra e a recusa à convocação extraordinária.

Candidatos possíveis que se enfeitam: Armando de Salles, Medeiros Neto, José Américo... Outros virão (VARGAS, 14/12/1936, p.568).

Getúlio Vargas parecia ansioso por uma conversa com Armando de Salles Oliveira acerca da prorrogação do "estado de exceção", isto é, de guerra. Apesar do discurso realizado em São José do Rio Pardo, o governador paulista ainda não havia confirmado oficialmente sua intenção de renunciar ao governo e candidatar-se à sucessão presidencial. Esse jogo de "atira/esconde", afirma/nega, praticado por Salles Oliveira já incomodava Getúlio Vargas, que registrou em seu diário: 
[...] Recebo o ministro da Justiça, que vem trazer à minha assinatura o decreto de prorrogação do estado de guerra e comunicar a próxima vinda do governador Armando de Salles para entender-se comigo!

[...]

Finalmente, recebo o governador de Minas... Procuro tranquilizá-lo através do intermediário, e combino com este a possível atuação junto ao Armando de Salles, antes do encontro comigo, para afastálo da atitude que pretende tomar.

Amanhã deve chegar o governador de São Paulo. Afigura-se-me um acontecimento decisivo no caso da sucessão presidencial. (VARGAS, 15 a 17/12/1936, p.569).

Finalmente, depois de tantos boatos acerca da sucessão presidencial, Getúlio Vargas e Armando de Salles Oliveira se encontram. O primeiro tentando dissuadir o segundo da ideia de se lançar candidato.

Aí, às 9 e meia da noite, recebi o Armando Salles, Conversou sobre várias coisas, perguntou muitas outras e, depois de informado, abordou o assunto: a renúncia, a necessidade de desincompatibilizar-se, não para ser candidato à Presidência da República, mas para enfrentar dentro de São Paulo uma luta política contra um candidato perrepista. O pretexto era visível, o motivo, fraco, a hipótese do candidato perrepista, muito hipotética.

Falei-Ihe com amizade, com carinho, mas com firmeza, fazendo-lhe ver que isso, em primeiro lugar, era a quebra do compromisso de não discutirmos o assunto senão no ano próximo; em segundo, a vitória moral do Flores, que pretendeu exatamente forçar essa discussão; em terceiro, o pretexto para explorações de toda ordem e a intranqüilidade para $o$ seu próprio estado e para $o$ país. Conversamos muito, e ponderei-lhe que pensasse melhor, falasse novamente aos amigos, aos seus correligionários etc. Ficou de assim fazer e retirou-se já cerca das 13 da manhã (sic) (VARGAS, 18/12/1936, p.570).

Percebe-se, nesse jogo de gato/rato, que Salles Oliveira também é cuidadoso e escorregadio ao falar com Getúlio Vargas, não declarando explicitamente sua vontade de ser candidato à presidência da República. A razão de se afastar do governo para enfrentar um possível candidato perrepista era mesmo um visível pretexto e uma hipótese "muito hipotética". Anteriormente apresentamos a interpretação do jornalista Vivaldo Coaracy, a respeito dos motivos que levaram Armando de Salles Oliveira a optar pelo confronto com Vargas e candidatar-se às eleições presidenciais. Para o jornalista, a candidatura começou a ser articulada em função da proposta de prorrogação do mandato presidencial, feita por Vargas. 
Entendemos que essa ação fazia parte de um projeto maior, era um dos últimos patamares desse projeto que começou a ser executado quando o político assumiu, com a indicação de Vargas e apoio de seu grupo, a interventoria de São Paulo. Não por acaso, logo após tornar-se interventor, fundou o Partido Constitucionalista. A administração do grupo armandista à frente do governo estadual já vinha sendo difundida e alardeada na imprensa, através de seu porta voz, o jornal O Estado de S. Paulo. O momento era de avançar e buscar o último posto presidencial do regime político, a presidência da república. Na madrugada de dezembro de 1936, Getúlio Vargas ainda registrou os movimentos do político paulista: "Armando recolheu-se ao hotel, e aí tem estado recebendo os políticos e conversando. Nada mais soube, Continua expectante, uma grande curiosidade" (1936, p. 571).

Em 25/12/1936, o jornal OESP publicou a notícia de renúncia de Armando de Salles Oliveira ao cargo de governador de São Paulo, para assumir a chefia do Partido Constitucionalista. No dia 29 de dezembro de 1936, em sinal ostensivo de defesa do princípio autonomia consagrado no pacto federativo, Armando de Salles Oliveira transmitiu o cargo de governador do Estado de São Paulo ao presidente da Assembleia Legislativa, Henrique Bayma, sem que seu ato tivesse sido comunicado, anterior e primeiramente à presidência da República. Afinal, como sua atitude queria mostrar, ele havia sido eleito pelo povo paulista representado na Assembleia pelos seus deputados. Por ocasião de sua renuncia, em discurso de transmissão do cargo de presidente da Assembleia Legislativa, aquele Salles Oliveira afirmou: "A minha renúncia obedece ao simples intuito de servir melhor a São Paulo e ao Brasil. [...] O que o nosso Partido quer é simplesmente isto: que o Brasil continue." (OESP, 30/12/1936, p. 4). Nesse mesmo mês, no dia 31 de dezembro, foi realizada uma eleição pela Assembleia Legislativa, que escolheu Cardoso de Melo Neto para ocupar o lugar de governador de São Paulo. A renúncia somente foi formalmente comunicada ao Presidente da República, Getúlio Vargas em 30 de dezembro (OESP, 30/12/1936, p. 4).

A renúncia de Salles de Oliveira ao cargo de governador de São Paulo, ainda dentro do prazo de desincompatibilização estabelecido pela Constituição, mereceu de Assis Chateaubriand a seguinte nota na imprensa:

A renúncia do sr. Armando de Salles Oliveira foi, assim, a chave da democracia dentro da jungle da sucessão. Ele era o único recurso 
para o qual uma situação destituída de sólidos fundamentos morais poderia apelar. Com a sua renúncia, deu o governador paulista um testemunho esmagador da certeza quanto ao livre funcionamento do regime. A rotatividade no exercício das funções públicas é tudo o que uma democracia ainda mediocremente organizada espera, afim de sobreviver. [...] Em dado momento, se tornou indispensável que um homem público, subjugado pelo peso de responsabilidades formidáveis, tivesse a coragem de afirmar o direito da democracia de ver a sucessão do sr. Getúlio Vargas. Esse ato custava o sacrifício da cadeira, donde um grande cidadão rutilava a mais bela festa veneziana da inteligência cívica que ainda viu o Brasil após os noturnos de Ruy Barbosa. Ele não hesitou um minuto na adoção da medida que afastava do cenário brasileiro, "o majestoso horror da ditadura. Quando Armando de Salles renunciou ao cargo de governador, a questão da sucessão presidencial deixou de ser uma incógnita (OESP, 08/04/1937, p. 15).

\section{Getúlio Vargas tinha expectativas de que Armando de Salles Oliveira o consultasse antes de renunciar ao governo de São Paulo e anunciar sua candidatura. Para atingir Vargas, a quem fazia àquela época declarada oposição, Assis Chateaubriand elogiou o fato de Armando de Salles Oliveira não se reportar ao presidente para anunciar sua renúncia. Reforçava, assim, a tese de que os Estados da federação eram detentores de suas autonomias, não necessitavam do aval da Presidência da República:}

Não nos ponhamos com meias palavras e nem "detours". A verdade e uma só. Existe em São Paulo, nos quadros da revolução, um candidato, que fez com Getúlio Vargas o que Getúlio Vargas fez lindamente e democraticamente com Washington Luis. Não pediu ao Catete licença para ser candidato. Vendo o Partido Constitucionalista que a nação brasileira tinha no coração o nome do seu presidente para suceder ao sr. Getúlio Vargas, recorreu às vias claras e limpas, com que na era da revolução um homem, ou um partido se podem tornar candidatos ou tê-los, para qualquer função pública. Fez o P.C. o provável candidato renunciar em tempo hábil o posto que o incompatibilizava para a eleição, e, corretamente, deu ciência desse passo ao presidente da República. Nada mais fez o Partido Constitucionalista do que isto. (OESP, 10/04/1937, p. 14).

Na leitura de Chateaubriand, não se tratava de um golpe, nem mesmo de insubordinação: era o pleno exercício de um direito assegurado constitucional e democraticamente, via atuação do Partido Constitucionalista. Assim, em 1937, a candidatura de Armando de Salles Oliveira tornou-se oficial, confirmando enfim as fundadas suspeitas de Vargas. O ex-governador de São Paulo enviou telegramas aos interventores de todos os estados da Federação, comunicando sua candidatura, 
exteriorizando sua busca por apoio político. ${ }^{43}$ Foi também pessoalmente comunicar Vargas acerca de sua decisão. A respeito da reação de Vargas, Vivaldo Coaracy recorda:

Perguntei a Armando qual fora a primeira impressão de Getúlio quando ele Ihe comunicara que ia se candidatar. Respondeu-me:

- Surpresa. Apesar de tudo que os jornais têm publicado sobre a possibilidade de minha candidatura, parecia não acreditar. A primeira reação, quando Ihe anunciei, foi de legítima surpresa. Exclamou com espanto: "O Senhor, Dr. Armando?!"...

Armando the perguntara se não o julgava em condições de aspirar à Presidência da República e Getúlio, logo recomposto da surpresa inicial, readquirira a impassibilidade glacial, dissera que certamente, não havia dúvida, e que Ihe desejava o melhor dos sucessos. Quis em seguida saber a quem pretendia passar o governo de São Paulo e, quando soube que era a Cardoso de Melo Neto, aprovou e mostrou-se satisfeito. Mas a entrevista fora muito breve. Não poderia ter sido mais sucinta.

$[\ldots]$

Como explicar a surpresa manifestada por Getúlio Vargas? Parecia incompreensível. (COARACY, 261, p. 280).

A surpresa de Getúlio Vargas pode ser traduzida sob várias possibilidades: jogo de cena, simulação, recusa em conferir importância ao candidato, em demonstrar seus receios, e uma dose forte de frustração. O presidente parecia ainda ter esperanças, ou em sua capacidade para virar o jogo, ou na garantia de que a conversa tida anteriormente com Armando de Salles Oliveira, a respeito da necessidade de adiar o debate sucessório e manter o país unido diante de uma possível ameaça comunista, surtisse efeito. Frustração porque, segundo Vivaldo Coaracy, a candidatura de Armando de Salles Oliveira desarticulava de uma vez por todas seu plano de prorrogar o mandato presidencial. Sem a participação e apoio de São Paulo, nenhum acordo seria conseguido nesse sentido:

A trama que visava, sob aparências legais, mediante ação do Congresso, à prorrogação dos mandatos eletivos, como processo suave de manter Getúlio Vargas no poder, fora desarticulada e desfeita pela atitude de Armando de Salles Oliveira ao se candidatar à sucessão presidencial. Terá havido, provavelmente, nas hostes getulistas, entre os promotores do projeto, manipuladores do continuísmo, um momento de confusão. A audácia e solércia de Getúlio sempre deu provas, não se deixariam, contudo, vencer pelo simples desmonte do plano bem arquitetado. Cumpria criar novo

\footnotetext{
${ }^{43}$ Os telegramas foram guardados por Paulo Duarte e compõe a pasta de documentos a respeito da campanha eleitoral. A pasta encontra-se no Fundo Paulo Duarte (IEL).
} 
processo para chegar ao mesmo resultado. (COARACY, 1961, p. 285-6).

"Cumpria criar novo processo" para se manter no poder, pois, Salles Oliveira oficialmente lançado como candidato para o próximo pleito, com campanha eleitoral prestes a ser iniciada e com outros possíveis candidatos surgindo no cenário política, já não era mais possível impedir o debate sucessório. Vargas pensou então um caminho alternativo para prorrogar seu mandato. O golpe de Estado passou assim a ser articulado, embora não fosse possível aplica-lo sem as necessárias articulações políticas e militares e nem imediatamente. De acordo com Coaracy, Vargas optou por envolver-se na campanha eleitoral, por certo para ganhar tempo, daí sua atitude quase apática, ao indicar quem deveria ser seu sucessor. Uma maneira de aparentar o cumprimento da Constituição. O candidato oficial do governo foi José Américo de Almeida, político paraibano. Como bem avaliou Coaracy:

Era preciso, porém, ganhar tempo, compor atmosfera. Havia que levantar uma candidatura provisória para opor à de Armando, favorecendo a formação de ambiente, proporcionando condições para o amadurecimento do plano que conduziria à supressão das eleições. Quem melhor para representar - inconsistentemente, devese dizer - esse papel de candidato-fantasma do que José Américo de Almeida? O seu próprio temperamento arrebatado, a sua índole impulsiva, a sua oratória violenta e desconchavada, eram fatores eficazes à criação de um clima turbulento de agitação superficial. E assim nasceu a sua candidatura, promovida por aqueles que nunca pretenderam leva-la a termo. (COARACY, 1961, p. 286).

A indicação de José Américo de Almeida era para ganhar tempo, compor "atmosfera", representar seu papel no jogo eleitoral. A indicação do candidato oficial mostra Vargas fazendo seu jogo, iniciando sua ofensiva. Ao mesmo tempo, algumas medidas começaram a ser tomadas no sentido de criar um ambiente propício para o golpe e para esvaziar o debate e as articulações políticas em torno da sucessão presidencial.

Com efeito, fracassadas as tentativas de prorrogar o mandato e de adiar o debate sucessório, Getúlio Vargas, a partir de janeiro de 1937, passou a orquestrar uma articulação entre governadores e partidos políticos para encampar a ideia de promover uma convenção na qual se decidiria os rumos do debate sucessório e escolheria um candidato único à sucessão de Vargas. Segundo Aspásia Camargo: 
Este encontro, norteado pelo princípio de que caberia ao presidente da República conduzir a escolha de seu substituto, deveria ser promovido pelos governadores de estado e pelos partidos políticos. Os convencionais seriam delegados partidários, deputados, senadores e representantes das diversas entidades e associações de classe. O ministro da Justiça coordenaria o evento, e seus participantes assumiriam o compromisso público de aceitar o candidato ali aprovado (CAMARGO, 1989, p. 130).

A maioria dos governadores e de partidos situacionistas aderiram e apoiaram à proposta de uma convenção cujo objetivo era legitimar a tese do candidato único. Até mesmo alguns setores tradicionais da oposição aderiram à ideia. Foi o caso do Partido Republicano Paulista, cujos quadros faziam oposição ao Partido Constitucionalista de Salles Oliveira. Contra a ideia de um candidato único, ficaram as correntes ligadas ao PRL, no Rio Grande do Sul, e ao Partido Constitucionalista, em São Paulo, que denunciaram a ideia como arbitrária e artificial. A proposta de escolher um candidato único, Assis Chateaubriand comentou, relembrando a revolução de 1930:

Como fracassasse a prorrogação, os traidores do regime agora, lançam o balão de ensaio do candidato único. Sabem o que é o candidato único, fórmula sucedânea da prorrogação? É o desconto prévio de que as forças democráticas, que querem eleições livres, não concordando, não podendo concordar com o candidato oficial que lhes é imposto, aceitarão, impávidas, hoje como em 1929, O pleito cívico. (OESP, 16/04/1937, p. 8).

O jornalista, na condição de defensor da candidatura de Armando de Salles Oliveira, relembra os ideais defendidos por aqueles que levaram o país até a revolução de 1930. A ideia era apontar que o grupo político armandista não havia mudado, continuava a defender os princípios democráticos, pelos quais eles haviam lutado em 1930 e em 1932. Nesse sentido, caso Vargas apoiasse abertamente algum candidato, estaria traindo aqueles ideais. De modo que Armando de Salles Oliveira e seu grupo político conduziram a campanha eleitoral indicando fidelidade aos ideais das revoluções de 1930 e 1932, se apresentando como único projeto possível para retirar o Brasil da crise que o país vivenciava naquele momento. 


\section{CAPÍTULO II: "PARA QUE O BRASIL CONTINUE". A CAMPANHA PRESIDENCIAL E O GOLPE DE NOVEMBRO DE 1937}

Ninguém se lembra de 1937, apesar da exortação de Café Filho: "Lembrai-vos de 37". Até porque ameaças à democracia não vão hoje pelo caminho golpista. Há outros, mais sutis. (FAUSTO, 2014, p. 117).

\section{1. "Jornada Democrática": A campanha eleitoral de 1937}

Acompanhamos a campanha eleitoral que ocorreu durante o ano de 1937, visando às eleições presidenciais previstas para janeiro de 1938, com o intuito de identificar e compreender o jogo político protagonizado pelo grupo político de Armando de Salles Oliveira com o propósito de tornar seu projeto vitorioso. Este grupo político armandista precisou executar uma campanha eleitoral que desarmasse e/ou enfraquecesse não só os candidatos concorrentes, mas também Getúlio Vargas e seus planos de continuar à frente da presidência da República. Aquele grupo paulista foi porém derrotado, uma vez que o ano de 1937 terminou com o golpe de estado que deu início a um período de oito anos de ditadura, conhecido como Estado Novo, sob a hegemonia de Getúlio Vargas e de seus aliados e/ou cooptados. Todavia, esse resultado não pode cooptar ou esmaecer a ação política dos armandistas, seus acordos, ajustes e também confrontos e combates. Nosso propósito aqui é justamente conhecer essa ação, localizá-la em seu tempo. Daí conferirmos à campanha eleitoral uma posição de destaque nessa luta, no jogo político travado, com o cuidado de evitar uma leitura já demarcada pelo resultado final que os embates políticos daquele ano produziram e o tempo e a historiografia já consagraram como determinante do golpe do Estado Novo. Nesse sentido, foi importante pensar a atuação do grupo armandista e também a atuação de Vargas em seu tempo histórico que vai além dos restritos marcos cronológicos tão bem conhecidos. Tempo de crise das oligarquias, de processo de urbanização, de expansão de São Paulo, de coexistência do antigo e do novo nas propostas partidárias do período.

Durante dez meses do ano de 1937, a questão da sucessão presidencial ocupou destaque na imprensa nacional, como foi assinalado. Além de Armando de 
Salles Oliveira, lançaram-se dois outros candidatos: o paraibano José Américo de Almeida, representando forças antigas e novas do Norte e Nordeste do país e com apoio de setores do tenentismo ${ }^{44}$; Plínio Salgado, chefe da Ação Integralista Brasileira $^{45}$ era o outro candidato, com forte apoio de setores católicos de viés integralista (PANDOLFI, 2002). O candidato José Américo de Almeida foi escolhido pela convenção nacional de 25 de maio de $1937^{46}$, tornando-se o candidato da área governamental. Antes mesmo que a convenção fosse realizada, o Partido Constitucionalista, contrario à escolha de um candidato único e querendo deixar claro tal posicionamento, antecipou-se ao anúncio formal do governo e lançou a candidatura de Salles Oliveira, em 15 de maio de 1937. Já a candidatura de Plínio Salgado surgiu em junho de 1937, com a campanha eleitoral já em estado avançado de implantação.

Houve intensa campanha eleitoral, mas não houve eleição. Entretanto, a campanha eleitoral vivida durante aquele ano nos ajuda a compreender como o grupo armandista lutou por colocar São Paulo na centralidade das decisões nacionais, ao defender um projeto político comprometido com a causa nacional. $\mathrm{O}$ grupo buscou, estrategicamente, desfazer e/ou esmaecer, silenciar algumas imagens vinculadas a São Paulo, que contrariavam a de nação e de nacional, dentre elas a de unidade separatista da federação, construída a partir de sua atuação na revolução de $1932^{47}$. Desfazer tal imagem tornou-se imperativo no projeto paulista, pois era preciso dar sentido ao discurso eleitoral dos armandistas, centrado na ideia

\footnotetext{
44 José Américo de Almeida foi secretário geral de estado na Paraíba durante a gestão de João Pessoa. Com a morte de João Pessoa, José Américo de Almeida assumiu ainda a Secretaria de Segurança e, posteriormente, foi nomeado governador geral do Norte. Com a revolução de 1930, foi designado por Vargas interventor do estado da Paraíba, deixando o cargo para ocupar o Ministério da Viação e Obras Públicas, a convite daquele. Foi ainda senador pelo estado da Paraíba, em 1935. Na convenção de 25 de maio de 1937, o nome de José Américo de Almeida foi apoiado por quase todas as situações estaduais (PANTOJA, Sílvia. Dicionário Histórico Biográfico Brasileiro pós 1930. 2. ed. Rio de Janeiro: Ed. FGV, 2001. Disponível em: http://www.fgv.br/cpdoc/acervo/dicionarios/verbete-biografico>. Acesso em: 25/05/2016).

${ }^{45}$ Plínio Salgado fundou a Ação Integralista Brasileira (AIB) em outubro de 1932. Rapidamente, entre 1932 e 1937, a AIB transformou-se num partido de massas, fundando núcleos políticos em dezenas de cidades, espalhadas pelo Brasil, e estabelecendo uma enorme rede de imprensa pelo país, o que seria de grande utilidade na campanha eleitoral. Em 1937, Plínio Salgado ambiciona alcançar a presidência da República, lançando-se candidato pela AIB (VICTOR, 2005).

${ }^{46}$ A convenção nacional foi proposta pelo situacionismo com a finalidade de indicar um candidato único à sucessão presidencial.

47 Segundo o historiador Marco Antônio Villa, a crítica ao elemento regionalista e separatista atribuído à Revolução de 1932 deu-se no sentido de enfraquecer o apoio paulista junto às outras unidades da Federação. 0 historiador assinalou que: "Se houve no interior do movimento manifestações de um regionalismo conservador, a hegemonia foi dada pelos setores democráticos, que defenderam enfaticamente a reconstitucionalização do Brasil - isto explica o apoio político recebido de outros estados da federação" $(2010$, p. 7).
} 
da grandeza nacional, sob a liderança de São Paulo, sem sequestrar as outras unidades da federação de sua autonomia e também de pertencimento à nação. Nesse sentido, o jornal O Estado de S. Paulo (O ESP) teve papel fundamental na campanha.

Tal como as historiadores, Maria Helena Capelato e Maria Lígia Coelho Prado, cujos estudos sobre a atuação do jornal entre os anos de 1927 e 1937, destacam aquele papel, igualmente entendemos que o periódico funcionou como "instrumento de intervenção na vida política e na modelagem da consciência social de segmentos significativos da sociedade brasileira" (PRADO; CAPELATO; 1980, p. 22). As autoras assinalam que os representantes do "bravo matutino", modo como o jornal O Estado de S. Paulo era conhecido, não foram meros espectadores da situação política vigente, mas protagonistas engajados no debate político do período, com o propósito de informar e formar a opinião de seus leitores. ${ }^{48} \mathrm{O}$ fundador do jornal, Julio de Mesquita, era membro atuante do Partido Republicano Paulista, mas recusou a ideia de transformar o periódico em órgão da imprensa do partido. Com sua morte, em 1927, foi Julio de Mesquita Filho quem assumiu a direção d'O ESP, mantendo, ao menos por um tempo, a sua condição aparentemente apartidária ${ }^{49}$. Por ocasião da primeira campanha eleitoral disputada pelo Partido Constitucionalista, em 1934, o jornal O ESP imprime porém uma mudança em suas diretrizes. Durante aquela primeira campanha, decisiva para consolidação do Partido Constitucionalista, o jornal abandonou com seu discurso apartidário para envolver-se explicita e diretamente na propaganda política dos candidatos daquele partido, investindo na legitimação e promoção de Armando de Salles Oliveira para o governo constitucional do Estado.

Entre 1935 e 1936, aquele periódico fez opção por defender abertamente o governo Vargas no combate ao avanço do perigo comunista, apoiando, inclusive, a alteração da Constituição, caso fosse necessário. Na avaliação de Prado e Capelato, tal decisão revelou-se porém equivocada, pois contribuiu justamente para a consolidação do golpe de novembro de 1937, caminho que o jornal não

\footnotetext{
${ }^{48}$ É necessário ressaltar, como defendido pelas autoras, que a imprensa já tinha importância expressiva na época. No caso do jornal O Estado de S. Paulo, a circulação diária era em torno de 110 mil exemplares. Seu alcance não era apenas regional, o jornal mantinha sucursais em outros estados (PRADO; CAPELATO; 1980).

49 Mesmo com o envolvimento dos membros do periódico com o Partido Democrático fosse do conhecimento de todos, o jornal continuou defendendo uma postura apartidária, até a fundação do Partido Constitucionalista, em 1934.
} 
concordava e não defendeu. Quando Vargas deu início à aprovação de uma série de medidas de cerceamento das liberdades, usando como pretexto o avanço do comunismo, o grupo armandista, através d'OESP, posicionou-se a favor de tais medidas. Com tal atitude, sua posição política liberal e de defesa da democracia e da constituição foi, à época, bastante questionada pela imprensa oposicionista.

Em 1937, provavelmente já cientes do fato de que um golpe de estado era mais do que uma remota possibilidade, mas uma ameaça tangível, pois estava sendo gestado no/pelo governo Vargas, os armandistas, durante a campanha eleitoral, reforçaram sua posição de compromisso do com a democracia. Assim, a Constituição voltou a ser defendida e os princípios democráticos enfatizados, colocados em primeiro plano. Segundo aquelas historiadoras, com a candidatura de Armando de Salles Oliveira à presidência da República, a prática liberal do grupo foi paradoxalmente reafirmada: "Se por um lado o jornal apoia as medidas anticonstitucionais impostas pelo chefe da nação, por outro, apresenta Armando de Salles Oliveira como o modelo do constitucionalismo, na sua trajetória desde a interventoria paulista até a candidatura à presidência da República" (1980, p. 61). Ou seja, atitudes díspares coexistiram na mesma época. A bandeira de combate ao avanço do comunismo, agenda que se tornou comum a Vargas e ao grupo armandista, e que tinha forte receptivade junto à sociedade, fez com que o grupo apoiasse medidas que o prejudicaram mais à frente, por servirem de apoio a Vargas e seu plano continuísta. Segundo Sandes (2012, p. 172), "o medo do golpe ensejou a aprovação das medidas exigidas para que o governo combatesse definitivamente a ameaça comunista. O apoio ao governo, em sua missão salvadora, é imediato." Até mesmo o jornalista Costa Rego, para quem a defesa do liberalismo era posição tão cara fez ásperas críticas ao grupo armandista e sua postura de aproximação do governo Vargas, por uma questão de preservação da ordem, acabam aproximandose do governo Vargas, ao apoiar as medidas tomadas por ele.

De modo que, quando Armando de Salles Oliveira declarou oficialmente sua candidatura à presidência da República e deu início à sua campanha eleitoral, tornou-se imperativo retomar ao tema da defesa da constituição e da democracia como bandeira prioritária. Esta foi a imagem que precisaria ser reforçada e disseminada para fazer frente às ameaças de golpe por parte dos comunistas e também do governo central. Em abril de 1937, já é possível identificar o discurso de 
defesa dos princípios constitucionais reaparecendo nas páginas do jornal. Em editorial d'O ESP, foi afirmado que Partido Constitucionalista não consentiria que o problema da sucessão presidencial se resolvesse sem estar totalmente amparado na Constituição (O ESP, 13/04/1937). A candidatura de Salles Oliveira não estaria vinculada a interesses pessoais de busca pelo poder, mas a uma espécie de "sacrifício" para garantir que a Constituição fosse respeitada.

Foi a sua voz que, restabelecendo a circulação de ideias, ecoou no ambiente ainda sem acústica criado pelo longo exercício da ditadura integral na democracia. Restaurou o sr. Armando de Salles Oliveira, em memoráveis discursos, a comunicação entre os mandatários e o povo, de que se haviam esquecido os homens públicos, viciados pelos entorpecentes do regime discricionários. Duas campanhas, a da sua eleição para governador e a dos pleitos municipais ofereceram-Ihe ensejo para de São Paulo falar ao Brasil. Todo o país entrou desde então em contato constante com esse valoroso pregador político da unidade nacional, conhecendo-lhe as ideias e as diretrizes de homem de Estado. O sr. Armando de Salles Oliveira, fiel aos seus sentimentos, coerente com as suas ideias, apegado às nossas tradições, convoca a nação para o debate, a luta eleitoral, o encontro das urnas. (O ESP, 13/04/1937, p.1).

Até o momento da candidatura de Salles de Oliveira, as matérias daquele jornal estavam prioritariamente voltadas para combater o "perigo vermelho", em função do qual era necessário tomar todos os tipos de precauções, o que incluía alterar a constituição. Entretanto, a partir do momento em que o grupo armandista vinculado àquele jornal compreendeu que a crise criada com e sob o argumento de avanço do comunismo podia ser mais um pretexto para impedir que as eleições ocorressem, o discurso do periódico adquire outra tônica e outra direção. $O$ jornal $O$ ESP passou a reforçar enfaticamente em seus editoriais que Salles de Oliveira era um político que respeitava, acima de tudo, a Constituição. Quando do momento de sua renúncia ao governo de São Paulo, já circulavam rumores de que o processo sucessório não se encaminharia de acordo com a Constituição. Como vimos, cogitava-se uma prorrogação dos mandatos de Vargas, dos governadores e dos parlamentares das Assembleias. Nesse sentido, o jornal publicou matéria em que se sublinhava que desde "esse momento (de sua renúncia), o Brasil inteiro ficou ciente de que São Paulo, mais uma vez, seria intransigentemente pelo regime constitucional. Tudo arriscaria por firmar o predomínio da Constituição"(OESP, 12/05/1937). Arriscou, inclusive, o trabalho até então realizado em São Paulo, como 
o próprio político confessou a Vivaldo Coaracy (1962): ele deixaria o governo de São Paulo, onde ainda havia tanto por fazer, para candidatar-se e defender o cumprimento da Constituição. Na confissão feita, a produção de uma memória de Armando de Salles Oliveira como estadista de visão nacional que abriu mãos de seus projetos locais e estaduais para defender a democracia e a união, representada na/ pela Constituição.

É desse gesto político que podemos pensar o projeto político armandista com projeções nacionais, além dos limites do regional. Uma prorrogação de mandatos beneficiaria a todos, inclusive aos governadores estaduais. Armando de Salles Oliveira sempre alegou precisar de mais tempo para realizar as obras necessárias no governo de São Paulo, restituindo àquele estado o prestígio pretensamente destruído pelos últimos anos de governo perrepista e, em seguida, por interventorias forasteiras ${ }^{50}$. Assim, apesar de a medida pudesse, à primeira vista, beneficiar também o governador paulista, a recusa da proposta de prorrogação de mandatos foi incisiva, pois, afinal, mantinha o status quo. Não por acaso, Salles de Oliveira discordou dela e combateu-a mantendo-se intransigente quanto a não prorrogação do mandato, renunciando inclusive ao cargo para disputar a presidência segundo a prática da democracia (CAPELATO; PRADO; 1980). Segundo editorial d'O ESP, "por preço algum consentiria que se tocasse no texto constitucional, ou se contornasse esse texto, para prorrogar o mandato do chefe da Nação e dos chefes dos Estados. A Constituição tinha que ser obedecida" (22/07/1937, p.2). A manutenção do status quo político no plano federal era situação que os armandistas e seu líder não defenderiam; eles iriam combate-la, pois contrariava e confrontava o projeto político do grupo.

Entre julho e novembro, meses em que a campanha eleitoral já estava sólida e ficou ainda mais intensa, o jornal O ESP lançou um caderno de propaganda política, intitulado Jornal do P.C. ${ }^{51}$ No total, foram 79 números publicados, com o conteúdo voltado para promover a candidatura de Salles Oliveira e fazer criticas à política de Getúlio Vargas no caso do debate sucessório. O espaço do caderno

\footnotetext{
${ }^{50}$ Como mencionado no primeiro capítulo, após a Revolução de 1930, a interventoria de São Paulo passou pelas mãos de vários políticos, sendo que nenhum deles era civil e paulista, descumprindo uma das exigências dos democráticos para apoiar Vargas na revolução.

${ }^{51}$ Durante a campanha eleitoral de 1934, o jornal fez o mesmo movimento, lançou o Caderno de Propaganda do P.C., uma espécie de suplemento político que vinha inserido dentro do jornal, espaço reservado apenas para o debate eleitoral e para rebater críticas da oposição.
} 
também era utilizado para publicar respostas às criticas da imprensa regional e nacional, contrária à candidatura Salles Oliveira. O Jornal do P.C. também serviu para divulgar a principal estratégia da campanha armandista: a exaltação dos progressos realizados pela administração de Salles Oliveira, nos campos econômico-financeiro, político e cultural. Enfatizava-se sobretudo que, sob a direção de Salles Oliveira, São Paulo teria recuperado a prosperidade outrora perdida (PRADO; CAPELATO, 1980). A intenção desses editoriais era clara: formar uma opinião política favorável à candidatura, já que na administração armandista, São Paulo prosperou, também o país se desvencilharia da crise política que estava vivendo, sob permanente ameaça dos comunistas, e alcançaria prosperidade econômica.

Já o candidato José Américo de Almeida, era herdeiro político de João Pessoa e fora escolhido como candidato do governo, sendo apoiado por todos os governadores estaduais, exceto pelos de São Paulo e do Rio Grande do Sul. Nesse contexto de articulações e apoios políticos, até mesmo os governadores da Bahia e de Pernambuco, que davam mostras de apoiar Salles Oliveira, já haviam entrado em entendimento com Vargas. Assim, a oposição ao governo estava publicamente ancorada no apoio daqueles dois estados e, também, nas dissidências de outros estados. Todavia, a habilidade do candidato paulista, ou "candidato nacional", modo como gostava de ser chamado, até que todos eleitores brasileiros se convencessem disso, fazia, sem dúvida, sombra ao inábil José Américo de Almeida que desagradava até mesmo a área governamental com seus discursos e suas ações. Nesse caso, a avaliação de Coaracy a respeito do apoio de Vargas ao candidato José Américo de Almeida mostrou-se acertada: o apoio nasceu somente para publicizar envolvimento de Vargas na sucessão presidencial, dando a entender que o pleito marcado para janeiro de 1938 ocorreria sem intervenções por parte do governo. Todavia, operava-se justamente o contrário, pois enquanto a campanha eleitoral acontecia, tramava-se o golpe de Estado.

Uma das críticas encontradas na historiografia a respeito do período é a de que o grupo do jornal $O$ Estado de $S$. Paulo teria sido condescendente todo o tempo com as medidas tomadas por Vargas para combater o comunismo, inclusive aquelas concernentes ao cerceamento da liberdade de imprensa. De modo que, quando efetivou-se o golpe de novembro de 1937, ele teria ocorrido de modo silencioso, sem 
grandes intervenções o confrontações. Teria tido até mesmo uma certa conivência por parte da imprensa ligada a Armando de Salles Oliveira. Estamos de acordo que, até certo momento, o jornal O ESP apoiou as medidas de Vargas, contribuindo indiretamente para que o golpe alcançasse sucesso futuramente. Entretanto, a partir da intensificação da campanha eleitoral e da suspeita de um projeto continuísta por parte do governo Vargas, o discurso propagado pelo periódico passou a denunciar a possibilidade de estar em gestação um golpe por parte de Vargas. É certo que os editoriais tinham uma postura reticente, cautelosa, até mesmo silenciosa. Todavia, não se pode ignorar que o mesmo jornal abriu seu espaço para publicação de outros artigos profundamente críticos e contundentes quanto à atuação de Vargas. $\mathrm{O}$ artigo de Pedro Vergueira, publicado no jornal $A$ Nação, foi reproduzido nas páginas d'O $E S P$ :

Em seguida, precisamos dizer ao Brasil, ao Exército, à Marinha, ao sr. Macedo Soares, e a todos os que nos queiram ouvir: a revolução comunista que o governo anuncia, que os amigos se comunicam, pelo telefone, que deverá explodir, de hoje para amanhã - se existe, se vai existir, é uma revolução oficial, mandada fazer pelo governo sob o rótulo de comunista, - em São Paulo e no Rio Grande do Sul, para tornar possível a intervenção federal, no segundo desses Estados - para depor o governo de Flores da Cunha e para permitir a continuidade do sr. Getúlio Vargas no poder. (OESP, 01/09/1937, p. 15).

O artigo é do início de setembro de 1937, momento em que os ânimos já estavam bastante acirrados por conta da campanha eleitoral. $\mathrm{O}$ articulista negava e desacreditava uma revolução que partisse dos comunistas e já suspeitava do uso daqueles para disseminar o medo e preparar o cenário para um golpe por parte do próprio governo. Pedro Vergueira continua:

Não fomos enganados, nem servimos de instrumento ao engano e essa onda de imbecilidade, de credulidade, de cegueira moral, avassaladora do país que permite tantos triunfos e tantas possibilidades ao gênio da corrupção e da sedução, e que enrola e escraviza o Brasil. Nos seus tentáculos, - não nos atingiu a nós, não nos corrompeu, não nos seduziu, nem nos cegou (OESP, 01/09/1937, p. 15).

Para Ângela de Castro Gomes (2007), São Paulo representa uma espécie de laboratório para se estudar os acontecimentos políticos da década de 1930. O jogo político praticado pelos paulistas naquela década nos ajuda a compreender o 
caminho que levou Getúlio Vargas ao golpe do Estado Novo, em 1937, e, posteriormente, à constituição de uma memória antivarguista construída entre e pelos membros derrotados do grupo político paulista, liderado por Armando de Salles Oliveira. Nesse sentido, é fundamental conhecer os principais discursos e posicionamento do grupo armandista durante aqueles anos e, principalmente, durante a campanha eleitoral de 1937.

O grupo armandista tinha consciência dos riscos que a campanha enfrentaria, não tanto pela disputa eleitoral com os outros candidatos, como a liderança de Plínio Salgado e a força mobilizadora da Ação Integralista Brasileira, mas devido à possibilidade real de uma intervenção por parte do governo Vargas da campanha eleitoral e no pleito eleitoral que se aproximava. A disputa não intimidava os paulistas, pois travar uma campanha eleitoral intensa, capaz de mobilizar o interesse da sociedade brasileira, era uma maneira de garantir que a eleição de janeiro de 1938 ocorresse; e era inclusive estratégia de ação do grupo armandista. Afinal, os paulistas já estavam experientes em campanhas eleitorais fortemente disputadas. Em outubro de 1934, já sob o novo Código Eleitoral de 1932, a população tinha ido às urnas, participando da primeira grande experiência eleitoral e democrática desde a Revolução de 1930 e promulgação da nova Constituinte. As eleições realizadas entre 1933 e 1934 foram as primeiras eleições efetivamente competitivas no Brasil. Às oposições vitoriosas foi garantida a possibilidade de assumir o poder. O pleito daquele ano nos mostra, portanto, um quadro que diferiu em alguns aspectos e práticas do que até então era praticado. Naquele momento, com o novo Código Eleitoral ${ }^{52}$, apesar do jogo político-partidário ainda permanecer muito restrito à esfera regional, é possível identificar uma desestruturação do antigo quadro político no que diz respeito às eleições. Uma das mudanças foi o surgimento de novos partidos, situação que permitiu o aumento do grau de competitividade (SILVA; SILVA, 2015).

\footnotetext{
52 Segundo Nicolau (2002), o Código Eleitoral de 1932 é responsável por mudanças importantes nos processos eleitorais dali em diante. O autor assinala que: "o Código Eleitoral, criado em 1932 e baseado em reformas eleitorais prévias, é considerado um momento de grande evolução das instituições políticas brasileiras. Com a adoção do Código de 1932, a circunscrição eleitoral para as eleições de governadores e deputados passaria a ser delineada de acordo com a extensão territorial dos estados brasileiros, e os eleitores poderiam votar em tantos nomes e candidatos quanto fossem cadeiras do estado na Câmara dos Deputados" (p. 51). Ainda mais, medidas como a adoção do voto secreto, a criação da Justiça Eleitoral e a representação proporcional vieram a contribuir para a desestruturação da lógica partidária que vigorava até então.
} 
Nesse pleito, foram eleitos deputados federais que substituíram os constituintes, também deputados estaduais, encarregados de elaborar as constituições estaduais, previstas para 1935, e vereadores, encarregados de elaborar as leis municipais. Com efeito, as eleições foram consideradas aquele momento uma experiência democrática positiva e vitoriosa. O alistamento e voto obrigatórios, instituídos pelo novo código eleitoral, tiveram considerável interferência no aumento do número de votantes e de um relativo crescimento da participação política de setores populares da sociedade. Até mesmo Getúlio Vargas, que temia que as urnas reconduzissem ao poder os antigos membros das oligarquias, comemorou a predominância de novos candidatos eleitos, sobretudo aqueles que haviam sido indicados por ele anteriormente, durante o interregno constitucional. $\mathrm{Na}$ ocasião, o Partido Constitucionalista travou uma verdadeira guerra na imprensa contra o Partido Republicano Paulista, garantindo vitória de seus candidatos e maioria no Congresso. Em 1935 foi a vez das eleições municipais para vereadores, realizadas também após intensa campanha eleitoral pelo Estado de São Paulo. Dela participou ativamente Armando de Salles Oliveira, na condição de governador eleito constitucionalmente. Também nestas eleições o Partido Constitucionalista garantiu vitória da maioria à seus candidatos. Janeiro de 1938 seria, então, a terceira e decisiva experiência eleitoral democrática pela qual o país passaria. Em São Paulo, democratização no plano legislativo já havia sido realizada; era hora portanto de estendê-la ao executivo (NETO, 2014).

O ESP vinha mantendo desde 1933 uma postura de apoio ao governo Vargas. Como já assinalado, já em 1935, o jornal apoiou as medidas de cerceamento às liberdades recentemente promovidas pelo executivo, criticando através de seus editoriais os políticos e partidos que se posicionaram contra aquelas, como foi o caso do Partido Republicano Paulista. O jornal publicou ainda artigos com críticas direcionadas às disputas locais e regionais, defendendo que se tratavam de disputas mesquinhas que enfraqueciam a democracia e abriam portas para o comunismo se fortalecer (CAMARGO, 1989). Entretanto, no início de 1937, após o desacordo público entre Getúlio Vargas e Armando de Salles Oliveira quanto ao debate sucessório, o periódico reorienta sua crítica a Vargas, mudando sua orientação de apoio ao governo Vargas. O ESP publicou então várias críticas ao posicionamento protelatório e ambiguo de Getúlio Vargas em relação à campanha 
eleitoral instalada no início de 1937, bem como à candidatura José Américo de Almeida, reconhecido como candidato oficial, indicado por Vargas.

Como já assinalado, na avaliação de Coaracy, o presidente, apesar de não estar de acordo com o início da campanha eleitoral, acabou por acatá-la ao expressar seu apoio ao candidato José Américo de Almeida. Esse modo de agir traduzia uma clara estratégia de ganhar tempo e assim articular apoio para elaborar um contra ataque, se possível para prorrogar seu mandato. O jornal O ESP criticou a atitude de Vargas, relembrando quais eram os princípios da revolução de 1930 . O rompimento entre Vargas e Armando de Salles Oliveira ficou claro quando o periódico começou a dedicar um espaço diário para críticos da postura do presidente no que diz respeito à sucessão presidencial. Um desses críticos era o jornalista Assis Chateaubriand ${ }^{53}$, que teve seus artigos publicados diariamente no Diário da Noite, reproduzidos n'OESP. Em um de seus primeiros artigos a respeito do debate sucessório, aquele jornalista mencionou as tentativas frustradas de Getúlio Vargas de persuadir os políticos a não se candidatarem à sua sucessão, acusando inclusive - Catete de "esfolar os cidadãos" com pretensões a candidato à presidência. Segundo a crítica do jornalista:

A campanha desenvolvida contra o sr. Armando Salles e a sua probidade administrativa apenas faz reforçar a convicção de que nestes últimos tempos só se morre, nas unhas do incondicionalismo do Catete, pelo crime de ser candidato à sucessão do sr. Getúlio Vargas. $\mathrm{Na}$ imprensa do governo se esfolam cidadãos que, sem licença oficial, tem a afoiteza de aspirar à presidência da República. (OESP, Assis Chateaubriand, 01/04/1937, p. 15).

O jornalista já vinha denunciando tanto Getúlio Vargas como o governador de Minas Gerais, Benedito Valadares, da reprovável pratica intervencionista de "caçarem" todos que demonstrassem interesse em candidatar-se à sucessão de Vargas, nas eleições marcadas para janeiro de 1938. Segundo Chateaubriand, esse

\footnotetext{
${ }^{53}$ Francisco de Assis Chateaubriand Bandeira de Mello, o Assis Chateaubriand, era paraibano. Jornalista e empresário da imprensa, chegou a ser proprietário de alguns jornais, como O Jornal, no Rio de Janeiro, e Diário da Noite, em São Paulo. Mais tarde, ao lado de outros jornalistas, fundou Os Diários Associados e também a revista O Cruzeiro. Apoiou ativamente a revolução de 1930, tanto via imprensa quanto em campo de batalha. Entretanto, a partir de 1931 teve início seu descontentamento com Getúlio Vargas e o Governo Provisório. Uma relação de aproximação com Getúlio Vargas só seria retomada após a chamada da Assembleia Nacional Constituinte. Em 1936, Assis Chateaubriand travou nova oposição contra Getúlio Vargas, movendo intensa campanha na imprensa onde acusava o presidente de tentar esvaziar o debate sucessório, com claras pretensões continuístas. (FERREIRA, Marieta. Dicionário Histórico Biográfico Brasileiro pós 1930. 2a ed. Rio de Janeiro: Ed. FGV, 2001. Acesso em 10/12/2015).
} 
foi o caso do presidente da Câmara do Rio de Janeiro, Antônio Carlos Andrada, a quem Vargas teria perseguido e retirado da presidência da Câmara justamente por desconfiar de suas intenções no sentido de tornar-se candidato presidencial ${ }^{54}$.

Em abril, ocasião em que apenas Armando de Salles Oliveira havia abertamente declarado sua candidatura, os rumores a respeito de uma candidatura oficial, apoiada por Getúlio Vargas, começaram a circular. Assis Chateaubriand imediatamente criticou a posição do governo:

Poderá um governo anti-intervencionista de origem, de substância, de medula, como o do nosso caro chefe, sr. Getúlio Vargas, ter um candidato oficial à presidência e, o que é mais sério, combater velada ou abertamente candidatos democráticos, por ele não considerados oficiais? Eis a delicada, a difícil postura em que se acha o presidente. O facto da renúncia do nosso distinto amigo sr. Macedo Soares, que até então não era candidato de qualquer força política, já foi de certo modo interpretado como um gesto de poucas avenças do primeiro magistrado com a outra candidatura paulista, primeiro sugerida. Automaticamente aumentaram as simpatias populares pelo homem que a opinião via objeto da suave pressão do polegar do presidente da República. A apresentação da candidatura Macedo Soares, não tendo à época da renúncia deste ao Ministério do Exterior, por detrás de si um Estado, um partido, um movimento de opinião coletivo, se algo traduzia, era o propósito do sr. Getúlio Vargas de ter candidato próprio à sua sucessão e de levar esse candidato às urnas como expressão de um sentimento hostil ao nome que o precedeu em São Paulo e que é o do sr. Armando de Salles (OESP, 01/04/1937, p. 15).

A crítica tinha procedência, já que uma das bandeiras defendidas pela Aliança Liberal era, justamente, o fim das candidaturas oficiais, em que os presidentes conforme a antiga prática, repassavam seus cargos para o candidato escolhido, fazendo com que o cargo circulasse e se mantivesse monopolizado por um grupo pequeno e ligado ao poder. A Revolução de 1930, ainda tão recente, tivera justamente em mira impedir que Júlio Prestes, candidato oficial do governo Washington Luís, assumisse a presidência. Embora tivesse ganhado as eleições, ele foi impedido de tomar posse, pois aquelas eram vistas como manchadas pelos vícios eleitorais de então, eram consideradas suspeitas. Não por acaso, a reforma eleitoral, provinda com o novo Código Eleitoral, ao lado do fim das candidaturas oficiais, foi uma das agendas de luta dos revolucionários da Aliança Liberal para

\footnotetext{
${ }^{54}$ No lugar de Antônio Carlos de Andrada, Vargas nomeou Pedro Aleixo para a presidência da Câmara. Assis Chateaubriand usou sua imprensa para denunciar fortemente as manobras intervencionistas de Getúlio Vargas e Benedito Valadares.
} 
extinguir aquela prática nefasta e oligárquica. Desse modo, tinha razão Assis Chateaubriand, ao denunciar o quão contraditório estava sendo Getúlio Vargas, líder revolucionário daquele movimento, de envolver-se diretamente na sucessão presidencial, ao explicitar apoio a um candidato em detrimento da candidatura paulista. Nas palavras daquele jornalista:

O brasileiro não participa mais da mística da invencibilidade dos governos nos comícios eleitorais. Um governador contra, era outrora, num pleito político, coisa de fazer tremer os mais confiantes. Essa escravidão já acabou. Suprimiu-a a revolução. Ou antes, o voto secreto, a cabina indevassável. Não há governo que logre impor um candidato impopular no seu eleitorado. As saturnais do velho regime, em que os governadores fabricavam centenas de milhares de votos em atas falsas, intimidados os eleitores pelo aparato policial, já não são mais hoje possíveis. Porque quem tem a palavra em eleição agora, são duas entidades: a primeira é o povo, e a ultima a justiça eleitoral. [...] A partir de 1933 já não é mais possível um governador desprezar os imponderáveis da opinião pública na apresentação dos candidatos ao sufrágio popular. A vitória de uma candidatura presidencial deixou assim de repousar no arbítrio de dois ou quatro governadores para se firmar na simpatia de que goza o favorito no seio dos colégios eleitorais (Assis Chateaubriand, OESP, 02/04/1937, p. 14).

Em razão de conquistas democráticas, como o voto secreto, cabine indevassável, e a justiça eleitoral, Assis Chateaubriand ressaltava e investia no fato de que a intervenção de Getúlio Vargas na campanha eleitoral não seria capaz de alterar os resultados, como ocorria em outros tempos, anteriores à Revolução de 1930, sem a garantia de tais dispositivos legais e institucionais. Com efeito, o advento da Justiça Eleitoral teria imprimido mais lisura nos processos eleitorais, expurgando velhas práticas, como a das atas falsas e intimidação dos eleitores.

Além de Getúlio Vargas, o grupo armandista ainda enfrentava, mais uma vez, a oposição do Partido Republicano Paulista dentro de seu Estado. O PRP aprovou a candidatura de José Américo de Almeida, fazendo dele seu candidato oficial. Para contrapor-se à candidatura de Armando de Salles Oliveira, o PRP, até então crítico incansável de Getúlio Vargas desde a Revolução de 1930, quando o foi apeado do poder, aproximou-se estratégica e oportunamente do Presidente em 1937:

Toda a luta do P.R.P. contra o Sr. Armando de Salles Oliveira decorre explosivamente desse fato: é que o ex-governador não quis, em 1933, aliar-se ao P.R.P., contra a revolução. Nomeado interventor de S. Paulo, o Sr. Salles de Oliveira soube discernir, com 
inteligência, o bem e o mal que a revolução trouxera à $S$. Paulo. A safra dos males tinha acabado. Era preciso tirar da revolução todo o bem que ela nos poderia oferecer, e que já nos havia proporcionado, pelo menos no caso do café. Dispôs-se o P.R.P. a entrar em conspirações militares contra o Sr. Getúlio Vargas e a revolução. Agiu o senhor Salles Oliveira em sentido inverso. Acatou a autoridade do chefe da revolução e contra esta recusou-se a entrar em conspirações (OESP, 03/03/1937, p. 16).

Para desautorizar e enfraquecer a candidatura Armando de Salles Oliveira, o PRP se aproximou e se aliou a Vargas, colocando o jornal O Correio Paulistano em prol da candidatura de José Américo de Almeida. Identificado até então como um jornal de oposição a Vargas, tendo sido inclusive empastelado por duas vezes por aquele governo ${ }^{55}$. Não se tratava mais de apoiar um candidato paulista, como até então se fizera crer, mas de apear Armando de Salles do poder e impedir que sua candidatura fosse vitoriosa. Os perrepistas poderiam voltar a ter espaço político ao aproximarem-se de Vargas, já que durante o governo dos constitucionalistas, a possibilidade de recuperar antigos privilégios sequer existiu. As matérias veiculadas nos jornais apontam-nos para o intrincado jogo político do período, que envolvia mudanças de posições, apoios e oposições internas, próprias das forças de São Paulo, e também externas, nas nem sempre transparentes relações de São Paulo com o governo Vargas. No intrincado e imprevisível jogo político nacional, a relação dos grupos paulistas, principalmente o armandista, com Getúlio Vargas foi marcada por impensadas, mas pragmáticas, aproximações e também distanciamentos entre seus correligionários e opositores.

Para Assis Chateaubriand, o movimento do PRP era claro: depois de sete anos de críticas à revolução de 1930 e ao governo Vargas, o partido buscou uma reaproximação com o presidente e com a intervenção federal em São Paulo. O objetivo era impedir a candidatura Armando de Salles Oliveira:

Eis a obra do PRP depois de sete anos de fingida irreconciliabilidade com a revolução: cai nos braços do sr. Getúlio Vargas, levado pelo massacrador de S.Paulo, pela mesma mão imunda que derrubou o juiz Laudo de Camargo e ensanguentou esta terra altiva e cheia de melindres cívicos. A enormidade desse atentado aos vivos, que ainda vivem com bravura, e aos mortos que caíram com coragem, nos idos de 32. (OESP, 03/04/1937, p. 14).

\footnotetext{
55 Os empastelamentos do Correio Paulistano ocorreram após a revolução de 1930, quando o jornal foi tirado de circulação devido à oposição do PRP ao novo governo. O jornal voltou a circular somente em julho de 1934 .
} 
Publicar um artigo como esse, no qual o autor, o jornalista Chateaubriand chama Getúlio Vargas de "massacrador de São Paulo", em referencia à revolução de 1932, evidenciava que o afastamento entre o antigo interventor, Salles Oliveira, e o presidente não era mais novidade. De fato, naquele momento, março de 1937, a campanha à sucessão presidencial já era assunto veiculado diariamente na imprensa das principais cidades do país. Assis Chateaubriand denunciou a estratégia política pela qual Armando de Salles Oliveira buscou a construir um degrau para sua posterior ascensão política: a de composição com Getúlio Vargas. Tal aliança contrariava porém os interesses e expectativas do Partido Republicano Paulista. Este, desde que foi afastado do poder com a vitória da Revolução de 1930, promovia ataques diários através da imprensa ao chefe do governo central e a todos que dele se aproximavam. Armando de Salles Oliveira rebatia as críticas dos perrepistas com a afirmativa de que a "política era a arte de esquecer". O discurso do esquecimento foi tática de conciliação utilizada por Armando de Salles Oliveira para assumir a interventoria de São Paulo, cargo que exigiu aproximar-se de Vargas, fazer tábula rasa do passado recente. O passado, como fonte de orientação, para atuar no presente e fazer projeções quanto ao futuro, requeria abrir mão de antigas posições para a conquista da estabilidade almejada e de uma posição de poder. Para tal, era necessário pensar e praticar a política com certo pragmatismo e não apenas como disciplina partidária, daí associá-la a "a arte de esquecer". ${ }^{56}$ Apenas após serem dissipados os desentendimentos e amainados os ressentimentos, seria então possível proceder com o projeto de poder que se fundamentava em reforçar a nação e a nacionalidade, o pacto federativo e a centralidade de São Paulo no cenário político nacional. A expectativa de alcance do poder em nível nacional é a mola propulsora do projeto do grupo armandista, em nome do qual deveria ser posta em prática, pragmaticamente, a política como "arte de esquecer". Entretanto, tal premissa foi passageira, rompida com a campanha eleitoral de 1937. Nesta, uma nova correlação de forças e da relação entre o governo Vargas e as elites políticas estaduais foram estabelecidas.

\footnotetext{
${ }^{56}$ A ideia da política como "arte de esquecer" foi desenvolvida por Salles Oliveira em discurso proferido no banquete oferecido aos Deputados constituintes de São Paulo: “A política é, até certo ponto, a arte de esquecer. No momento em que se reúne a Constituinte, dissipadas para sempre todas as prevenções, devem os brasileiros se compenetrar de que nenhum entendimento será possível, nenhuma obra realizável, se o debate das ideias não se tratar sobre a rocha firme da nacionalidade" (OLIVEIRA, 2002, p. 28).
} 
Por ocasião da campanha eleitoral que extraoficialmente se iniciou no final de dezembro de 1936, quando Armando de Salles Oliveira deixou o cargo de governador para lançar-se candidato à Presidência da República, foi lançado o livro Jornada Democrática, em abril de 1937. Nele estão reunidos todos os discursos políticos que Armando de Salles Oliveira pronunciou desde sua eleição ao governo constitucional de São Paulo. Em anexo ao volume ainda estão alguns trechos da mensagem que o político apresentou à Assembleia Legislativa, em 1936, e que dizem respeito a algumas realizações de sua administração em São Paulo. O próprio Armando de Salles fez a seleção desses discursos e abriu o livro com um prefácio de sua autoria no qual anunciou o projeto político de seu grupo. Alguns trechos do prefácio são bastante significativos quanto a esse projeto, expressão do pensamento político de Armando de Salles Oliveira e de seu grupo:

Os que se derem a pena de ler estas páginas verificarão que há dois anos venho falando a mesma linguagem e que não variou a minha diretriz na defesa de princípios políticos que não são novos, que são até muito velhos, mas que se afeiçoam a índole e às tradições do povo brasileiro. E verão ao mesmo tempo projetar-se a sombra de certas inquietações - prenúncio de que se avizinhava o momento de submeter o regime e a nação a uma prova definitiva. Mais do que nunca, eu me prendo ao dogma da Federação: resistamos às tentativas de abatê-lo, se queremos resguardar a unidade do Brasil.

Os resultados colhidos nas cidades paulistas mostram o novo panorama que o Brasil poderia oferecer com um programa nacional, preparado e executado com o mesmo método (OLIVEIRA, 1937, p.118).

Salles Oliveira constrói seu discurso destacando São Paulo e os resultados ali obtidos graças à sua gestão à frente do governo estadual. São Paulo é a unidade da Federação identificada por aquele como modelo a ser seguido pelas demais. $\mathrm{Na}$ proposta de Salles Oliveira e de seu grupo político, São Paulo foi representada como a vitrine do programa político, econômico, cultural e educacional que eles desenvolveram no Estado e que eles pretendiam executar no país. Trata-se de uma proposta com amplitude nacional, respeitando o "dogma da federação", mas sob inspiração do modelo de gestão dos paulistas. Nesse modelo, sob descrição do próprio líder, destacavam-se:

A valorização social e econômica do indivíduo foi o objetivo principal visado pelo meu governo. É o que também mostrará o exame da obra realizada nos domínios da educação. A fundação da Universidade e da Faculdade de Filosofia, Ciências e Letras 
assegurou a formação de professores capazes de dar solução ao problema fundamental do país - a renovação integral do ensino secundário. Daquela faculdade partiu este ano a primeira turma, a que vai abrir caminho para a cruzada salvadora.

[...]

Defendemos com intransigência a Federação, porque em nossos espíritos o regime federativo é a condição essencial de existência para o Brasil.

[...]

O Brasil tem o direito de exigir que não se corrompam princípios em nome dos quais se ergueu, em movimentos espontâneos e irreprimíveis. Alcançamos um dos grandes ideais: o voto secreto, protegido e garantido pela Justiça. Desmentimos em três eleições o pessimismo dos detratores de nosso povo, servindo-nos com inteligência daquela maravilhosa arma dos povos livres. Preparamonos agora para a nossa experiência definitiva, em que se consolidará a ordem constitucional no Brasil. Não nos sentimos, eu e o meu partido, com animo de aceitar, para o ato máximo de nossa vida política, métodos que supúnhamos destruídos. Partindo de combinações obliquas, chegaríamos inevitavelmente a uma solução frágil. Confiamos nas urnas e não compreendemos o ceticismo dos que, ignorando a evidencia de que alguma coisa se transformou em nossos costumes políticos, pensam que a última palavra seria mais uma vez dada pelas armas, depois de nossas lutas fratricidas (OLIVEIRA, 1937, p.1-18).

Ao mencionar a valorização social e econômica do individuo, Salles Oliveira ressalta o viés liberal de seu projeto político, o respeito às liberdades individuais, inclusive no que diz respeito à participação na vida política do país, através do voto secreto e consciente. Esse viés perpassa todo o programa, haja vista a defesa da autonomia do Estado, do pacto federativo, do voto secreto, dos investimentos na educação e na cultura, da consolidação da ordem constitucionalista, perspectivas e iniciativas anunciadas como estruturantes do referido projeto político.

Observa-se que entre os anos de 1933 e 1936, durante a interventoria de Salles Oliveira, os paulistas construíram uma posição de prestígio junto ao governo federal que Ihes assegurou certa projeção e inserção no cenário nacional e nos quadros da administração federal. A política de alianças com Getúlio Vargas foi, sem dúvida, fundamental para o alcance de tais resultados. Esperava-se, assim, com as eleições marcadas para 3 de janeiro de 1938, que o grupo armandista iria conquistar uma posição de centralidade na cena política, recuperando o que fora perdido desde a Revolução de 1930. A disputa não seria mais pelas armas, mas pelo voto. Como 
Salles Oliveira mencionou em seu prefácio para o livro Jornada Democrática, as armas da Revolução de 1932 haviam sido trocadas pelas urnas, consoante a perspectiva liberal que informava as diretrizes e fundamentos do Partido Constitucionalista: a defesa do regime democrático, o pacto federativo, o funcionamento de sólidos partidos políticos nacionais, o voto secreto, a ênfase no progresso.

\begin{abstract}
Para que se fechasse o Congresso e se instituísse a ditadura foi preciso, antes, liquidar a eventual oposição do Rio Grande do Sul sob a alegação, que a realidade provou ser falsa, de um acordo entre os governos do Rio Grande do Sul, São Paulo e Bahia para impedir que Getúlio Vargas ferisse os direitos dos Estados Federados: União versos Federação, em suma. Além de iniciar o cerco de São Paulo a partir de Minas Gerais". (OLIVEIROS, 2007, p. 146).
\end{abstract}

Oficialmente a campanha eleitoral de Armando de Salles Oliveira começou em 4 de abril de 1937. Logo em seguida, em 17 de abril de 1937, o diretório do Partido Republicano Liberal (PRL), chefiado por Flores da Cunha, realizou um congresso para declarar apoio à candidatura Armando Salles Oliveira. Nesse evento político, o PRL aprovou, por unanimidade de votos, a candidatura do ex-governador paulista, decisão que foi amplamente divulgada pelo jornal O Estado de S. Paulo (OESP, 18/04/1937, p. 2). Além de enviar correspondentes para cobrir o Congresso, o jornal deu à notícia matéria de capa, enfatizando que a candidatura Salles Oliveira não era algo restrito ao estado de São Paulo, mas que contava com o apoio até mesmo de antigos desafetos, como o Rio Grande do Sul, terra do presidente Getúlio Vargas. A divulgação do apoio de outros estados tinha como propósito construir a imagem de aprovação nacional da candidatura. Inclusive evitava-se falar em "candidatura paulista", o termo usado pelo periódico era "candidatura nacional". É visível o investimento d'OESP na produção de um candidato nacional, fora do eixo e do alcance da influencia do governo Vargas, mas partindo de São Paulo.

As investidas por parte de Flores da Cunha para que Armando de Salles Oliveira se candidatasse, bem como o posterior apoio público a tal candidatura, causaram alguma surpresa entre os armandistas. Afinal, um ano antes, em abril de 1935, o jornalista Vivaldo Coaracy havia escrito uma carta para Armando de Salles Oliveira, abordando prematuramente o tema da sucessão presidencial. Em seu relato, Coaracy ressalta que se encontrava deveras preocupado com notícias de 
uma suposta articulação política visando à sucessão presidencial, em que estariam envolvidos Lima Cavalcanti, Juracy Magalhaes e Flores da Cunha. A informação que havia chegado até o jornalista foi a de que o governador gaúcho, Flores da Cunha, faria o possível para manter São Paulo de fora da disputa política em torno da presidência da República:

Diz-se por aí, em certos círculos revolucionários, que o Juarez teria escrito uma carta a determinados interventores seus amigos lembrando a conveniência para o Brasil de desde já serem concertadas forças políticas para apoiar a candidatura de Armando de Salles Oliveira à Presidência da República, na sucessão de Getúlio Vargas.

$[\ldots]$

Ao falar-Ihe da possibilidade sugerida pela tal carta, o Flores rompeu em impropérios, declarando, no meio dos palavrões em que o seu estilo é sempre abundante, que "Nunca mais o Brasil seria posto debaixo do chicote de S. Paulo"; que para evitar isso é que se fizera a Revolução; que ele preferiria entregar a futura presidência a Minas ou a qualquer Estado do Norte a consentir em que a mesma viesse a parar nas mãos da nefasta política paulista ${ }^{57}$.

Muita agua correu sob a ponte, entre 1935 e 1937. Em meio às mudanças de aliados, de troca de parceiros, Flores da Cunha anunciou apoio, em 1937, a Salles Oliveira, um produto da "nefasta política paulista". A suposta articulação revelou-se falsa e justamente aqueles interventores mudaram de posição, pois de opositores tornaram-se defensores na campanha pró-candidatura de Salles Oliveira. E o governo central passou a suspeitar de uma aliança armada entre os estados da Bahia, São Paulo e Rio Grande do Sul, sob a liderança do governador do Rio Grande do Sul, Flores da Cunha (OESP, 22/04/1937, p. 12). A suposta aliança foi inclusive um dos pretextos para Vargas fechar o cerco ao Rio Grande do Sul. Conforme já mencionamos, Flores da Cunha estava insatisfeito com o enfraquecimento da autonomia regional dos estados, não concordava com a centralização do poder nas mãos do executivo federal, orientação política que vinha sendo fortalecida desde 1930. Tal interferência no poder regional contrariava

\footnotetext{
${ }^{57}$ Unicamp. Arquivo Paulo Duarte. Dossiê Armando de Salles Oliveira. Pasta 34: carta de Vivaldo Coaracy para Armando de Salles Oliveira, em 29/01/1935.
} 
interesses das oligarquias regionais, opondo-as à política centralizadora do governo Vargas. Como bem avalia Camargo (1989):

De fato, o federalismo brasileiro, instituído pela Constituição de 1891 sob inspiração norte-americana, tanto quanto o positivismo autoritário de origem militar no início da República, foram forçados a moldar-se às peculiaridades de um sistema agrário regido pelo mandonismo, em que a chefia local se concentrava nas mãos dos coronéis. Este foi o espírito da política dos governadores, de Campos Sales, que teceu o pacto entre os chefes regionais e o poder central. As disputas e alianças entre as oligarquias, cujo o período crítico era sempre o momento da sucessão estadual ou presidencial, definiram assim, ao longo de décadas o cerne de uma política cuja dinâmica era estritamente regional. No período que antecedeu o golpe do Estado Novo, o poder oligárquico, variável segundo a força dos estados, manifestava-se tanto nas frentes regionais quanto no Congresso recém-eleito. Submetê-lo ao controle do poder central, muitas vezes, uma tarefa árdua e delicada, que exigiu de Vargas grande habilidade e determinação (p.75).

A relação de Flores da Cunha com Getúlio Vargas começou efetivamente a se deteriorar a partir de 1935. A atuação de Flores da Cunha provocou atritos com o poder central, quando este começou a fazer pressão para que o General Góes Monteiro fosse demitido do Ministério da Guerra. As posições dos dois eram divergentes e incompatíveis. Flores da Cunha defendia a autonomia dos estados no pacto federativo; Góes Monteiro era partidário de um governo central forte, de um exército nacional poderoso que exigia a redução da força militar dos estados, no que contrariava os interesses de Flores de Cunha. Este, desde 1932, vinha fortalecendo sua Brigada Militar ${ }^{58}$, força que representava um forte impeditivo às manobras continuístas de Getúlio Vargas.

Em visita ao Rio Grande do Sul, em 1935, por ocasião do aniversário da Revolução Farroupilha, Getúlio Vargas, assim como fez com outros governadores, teria sugerido o cancelamento da eleição prevista para 1938, ideia pronta e energicamente repelida por Flores da Cunha. (ABREU, 2001). Em 1936, o governador gaúcho deixa claro seu apoio de seu partido, o PRL, à candidatura Armando de Salles Oliveira, envolvendo-se diretamente na campanha eleitoral. ${ }^{59}$

\footnotetext{
${ }^{58}$ Flores da Cunha contava com seis mil homens da Brigada Militar, além de 20 mil civis da milícia de corpos provisórios e também aliados dentro do Exército.

${ }^{59}$ Posteriormente, no segundo semestre de 1937, Getúlio Vargas irá fechar o cerco em torno do Rio Grande do Sul, ameaçando uma intervenção militar. Em função disso, Flores da Cunha irá renunciar ao cargo de governador e fugirá para o Uruguai.
} 
Ainda que o grupo armandista já tivesse enfrentando e vencido outras campanhas eleitorais, a campanha presidencial de 1937 exigiu porém um maior envolvimento, afinal, tratava-se de uma disputa em torno da sucessão de Vargas. Paulo Nogueira Filho ${ }^{60}$, deputado federal e membro da comissão diretora do Partido Constitucionalista, ficou responsável pela coordenação da campanha eleitoral. Em entrevista ao jornal O ESP (18/04/1937, p.20), aquele político explicitou a dimensão da campanha eleitoral, cuja a estrutura havia sido montada pelo Partido Constitucionalista, o intuito era o de alcançar todo o território nacional. Com tal propósito, foi criada uma espécie de central de Departamentos, situada em São Paulo, com a função de dirigir outros departamentos menores, situados em outros estados, coordenando a campanha eleitoral. ${ }^{61}$ Uma importante medida tomada foi com relação aos alistamentos para votar. Segundo Nogueira Filho, havia a intenção de inaugurar um posto modelo de alistamento, que funcionaria na rua Barão de Itapetininga, em São Paulo, e seria depois transportado para outras capitais e cidades. A obrigatoriedade do alistamento e do voto, duas das mais importantes medidas impostas pelo novo Código Eleitoral de 1932, ${ }^{62}$ exigia agora uma intensa campanha de incentivo ao alistamento, além daquela em prol do voto ao candidato. Apesar de obrigatório, era necessário estimular e assegurar que a população cumprisse seu dever de cidadão quanto ao direito do voto. O jornal OESP fez sua parte divulgando exaustivamente a necessidade de se alistar e indicando os endereços oferecidos pelo Partido Constitucionalista, empenhado em cooptar novos eleitores. A função do Departamento de Alistamento era a de agilizar a entrega de

\footnotetext{
60 Paulo Nogueira Filho foi deputado federal entre 1935-1937, pelo Partido Constitucionalista. Foi um dos deputados do Partido Constitucionalista que apoiou vigorosamente a aprovação da Lei de Segurança Nacional e o fechamento da Ação Nacional Libertadora. Em 1938 foi preso e enviado para o exílio juntamente com Armando de Salles Oliveira e outros egressos do Partido Constitucionalista. (MAYER, Jorge Miguel. Dicionário Histórico Biográfico Brasileiro pós 1930. 2a ed. Rio de Janeiro: Ed. FGV, 2001. Acesso em 10/12/2015).

${ }^{61}$ Segundo o periódico, haviam sido designados políticos do Partido Constitucionalista para dirigir cada posto necessário para realizar a campanha eleitoral. Para dirigir o Departamento de Publicidade estava designado Leven Vampré; o Departamento de Propaganda ficou a cargo de Cecílio Lopes e compreendia um sub departamento de rádio e cinema, a cargo de Antônio José de Freitas. Ainda existiam seções de Aviação, Publicidade, Comícios, Bandeiras, Distintivos, Cartazes e Impressos. Um importante departamento era o de Alistamento, superintendido por Aristides de Macedo; a Tesouraria estava a cargo de Plínio de Queiróz e o Departamento de Ação Partidária se achava sob a direção de Thiago Mazagão Filho; já a Secretaria Geral era gerida por Eugenio de Toledo Artigas. A quantidade de departamentos criados dá mostra da dimensão de organização e tamanho da campanha eleitoral. (OESP, 18/04/1934, p. 20).

${ }^{62}$ Além disso, o Código Eleitoral de 1932 também criou a Justiça Eleitoral, que passou a ser responsável pelas fases do processo eleitoral: do alistamento dos eleitores, passando pela inscrição de partidos e candidatos, e também organização da logística do pleito, apuração dos resultados das eleições e aplicação dos mesmos, diplomando os candidatos eleitos. Uma estrutura que teve como espelho o poder Judiciário (NICOLAU, 2012).
} 
títulos de eleitores, com o intuito de aumentar o número de votantes no que dizia respeito ao pleito anterior, em 1934. Ao elaborar uma campanha eleitoral de grande porte, o programa político dos armandistas seguia a premissa democrática por eles amplamente defendida: caso fosse eleito por um número expressivo de eleitores alistados, Armando de Salles Oliveira estaria mais seguro, longe de ameaças golpistas. As urnas o elegeriam, o legitimariam e também assegurariam sua posse.

Nesse contexto, alguns nomes de possíveis candidatos à sucessão de Vargas começaram a surgir. Entre eles, José Carlos Macedo Soares, Ministro da Justiça, e Oswaldo Aranha, embaixador do Brasil em Washington. No início de 1937, Oswaldo Aranha retornou ao Brasil com o intuito de viabilizar sua candidatura presidencial. Entretanto, como seu nome não conseguia aglutinar apoio significativo, nem mesmo em seu estado, o Rio Grande do Sul, a ideia não foi bem aceita por Getúlio Vargas. Segundo Assis Chateaubriand, cada candidato que se apresentava, Getúlio Vargas se movimentava para dissuadi-lo e eliminá-lo:

Importante para fixar nesse episódio é o começo da usura do prestígio popular do presidente. Ao olfato subtil das multidões chegou o cheiro de sangue da matança de candidatos à sucessão presidencial. Principiou-se a raciocinar que as cutiladas desferidas no solerte Andrada eram em função do "cordon-bleu" de candidato que Ihe passara, em tempo inoportuno, o sr. Flores da Cunha. (OESP, 03/03/1937, p. 16).

Segundo Assis Chateaubriand, a estratégia de Getúlio Vargas era ir "fritando" possíveis candidaturas até conseguir impor uma candidatura oficial, sob sua influencia. Esse modo de agir de Vargas, de ir "minando" as candidaturas fora de seu raio de controle, era o de eliminar a força dos estados durante a campanha eleitoral. Essa clara interferência do governo central foi denunciada pelo jornalista:

O assalto às autonomias estaduais vem a ser assim uma bandeira de campanha presidencial. Antes de começar a jornada eleitoral apeamse os governos incômodos, podam-se as autonomias capazes de criar embaraços à candidatura do oficialismo. Reduz-se desse modo o problema da sucessão a um outro problema muito mais simples. Em vez de um pleito de sufrágio contra sufrágio, oferece-se uma briga contra seis ou sete governadores recalcitrantes. (OESP, 03/04/1937, p. 15).

Com efeito, a atitude intervencionista de Getúlio Vargas era direcionada justamente àqueles governadores que anteriormente recusaram sua proposta de 
prorrogação do mandato presidencial e do debate sucessório. Era preciso esvaziar e/ou impedir uma possível aliança entre Bahia, Rio Grande do Sul e São Paulo, para evitar o fortalecimento da campanha da candidatura Salles Oliveira; Conforme denunciou o jornal OESP:

Pela primeira vez, na história republicana do Brasil um chefe do governo federal se permite sem maior abalo, como o sr. Getúlio Vargas, aplicar a delicada terapêutica intervencionista, estejam os Estados enfermos ou sadios.

[...]

Esse desprezo do sr. Getúlio Vargas pelo sentimento de autonomia dos Estados, criado bem ou mal pelo regime federativo, e o desplante com que está processando essas manobras de que teremos que sofrer terríveis consequências, determinaram uma situação de fato revolucionária, qual seja a que se exprime na aliança defensiva de três Estados meça-se a gravidade desta previdência) afim de atuar na própria toca o presidente que se desvairou. Se a revanche de São Paulo, Bahia, Rio Grande do Sul, firmando oficial e publicamente uma aliança, constitui um caso inédito e alarmante no Brasil, essa ameaça ao poder central de um apelo às armas, não é senão o efeito da política insensata, vamos mesmo dizer subversiva e criminosa, traçada na sombra e executada a sangue frio pelo presidente da República. Estamos às portas de uma bagunça, de uma anarquia sem precendentes. (OESP, 03/04/1937, p. 14).

A técnica de eliminação de candidatos, praticada por Vargas, é também objeto de denuncias de Assis Chateaubriand. Em abril de 1937, após Oswaldo Aranha desistir de sua candidatura à sucessão presidencial, o jornalista publicou um artigo sob o título: "Getúlio Vargas mata candidatos na curva da estrada":

[...] Para acreditar na existência dessa base da candidatura Aranha, seria preciso admitir que a técnica do sr. Getúlio Vargas fosse desconhecida no Brasil. Um velho processo do ex-ditador são os treinos antes do jogo. Os candidatos que ele quis matar matou mesmo, e nós sabemos quais foram. Também aqueles com os quais decidiu brincar, deixou-os soltos, para que ele se fizesse de gato e os candidatos de camundongos. Está na família dos camundongos o serafim que se chama Oswaldo Aranha, como o seu terno irmão José Carlos de Macedo Soares, o qual ficou por aí brincando três dias de governador do estado do Rio, mas só três dias e nada mais. Depois o gato comeu filosoficamente o governador, com tripas e tudo (O ESP, 07/04/1937, p. 14).

Também a até então impensada a aproximação do Partido Republicano Paulista com Getúlio Vargas foi objeto de crítica de Chateaubriand. O jornalista 
comentou como Vargas se travestia em mais de um personagem, a fim de atrair ou desfazer alianças de acordo com seus interesses:

Vir a abraçar esta criatura gozada, que é Getúlio Vargas, conversar com este homem polido e agradável será algum ato feio que se deva negar em público? Produziu ainda o Brasil outro presidente com esse amável sorriso e essa capacidade de envolver e magnetizar as criaturas que Deus deu ao bruxo de São Borja? Reconheço o veneno sutil dessa mancenilha. Entretanto, Getúlio Vargas é assim mesmo. Só pode ser tomado a benefício de inventário, e o interesse humano da sua personalidade reside na variedade de homens que ele possui. Há o que conversa hoje com o PRP. São até dois inimigos que nem se falam. O que importou Oswaldo Aranha há quatro meses, para este inocente bate bola da sucessão, é inteiramente desconhecido do que depois de amanhã o exporta para os Estados Unidos.

\section{$[\ldots]$}

$\mathrm{Na}$ aliança entre o PRP e o governo central existe evidentemente um insulto, mas não um perigo. Mas o insulto é do presidente aos que lutaram consigo em 1930. Perigo para nós não há nenhum. Ao contrario, batemo-nos dentro de São Paulo, sem o handicap que, depois de ter criado para os outros, paz no próprio lombo, o PRP. (OESP, 14/04/1937, p. 3).

O jornalista não poupou nem mesmo o grupo armandista de suas críticas

ferinas. O comportamento intervencionista de Vargas e suas investidas para esvaziar a campanha eleitoral é objeto de um exercício de rememoração acerca do perigo que representava qualquer aliança com Vargas. Em artigo ele relembra então todas as vezes que Getúlio Vargas esteve contra São Paulo e depois articulou aproximação, travestido de amigo daquele Estado. A memória é usada para lembrar ao grupo armandista sua responsabilidade histórica de buscar compor alianças com Vargas:

Não é só a adversidade, como diz o inglês, quem promove "strange bedfellows". Também a ambição política, o desejo de subir, a volúpia de trepar, de atingir o poder, nos oferecem surpresas de companheiros estupefacientes de cama e mesa. Todos, em 1932, pegamos em armas contra o senhor Getúlio Vargas, nosso desabusado e paternalíssimo chefe. Acabamo-nos reconciliando e reconhecendo que ele era ainda um dos melhores pais sem entranhas. Mas, ao nos entendermos de novo, fizemos tabua rasa do passado. Ele não existia nem poderia existir. Pusemos num saco a revolução constitucionalista, as interventorias militares de São Paulo, os desatinos militares, os cartórios assaltados, a série de mentiras clamorosas perpetradas ao país pelos que vinha governar com os seus interesses e não com os da coletividade, e sacudimos toda 
essa horrível carga ao mar. Vida nova. Horizontes diversos. Foi como se Getúlio Vargas tivesse entrado e sabido do Asilo do Bom Pastor. Para nós ele vinha purificado, regenerado, limpinho, de azul vestido, catita como um Santo Antônio no seu andor. Somamos com ele rijamente, mais uma vez, e bem conscientes das responsabilidades que assumíamos (OESP, 14/04/1937, p. 13).

O projeto político dos armandistas, em razão de seu ambicioso alcance, evidenciou a necessidade incontornável de uma aliança com Getúlio Vargas,mesmo sabendo dos riscos que ela envolvia. Os paulistas já conheciam a disposição de Getúlio Vargas para não cumprir acordos que eram desfeitos com o surgimento de novos outros interesses por parte daquele. As várias personas de Vargas são expostas nos artigos do jornalista, nesse seu esforço em desconstruir o "bruxo de São Borja". Assim é que até o título de exímio pescador de pirarucus, atribuído à Vargas pelo jornalista Costa Rego, por ocasião das alianças que precederam a Constituinte de 1934, é objeto desse exercício crítico e desconstrutor de Chateaubriand:

Gênio eterno do diabo, com que espiritualidade despedaças as cadeias de escravidão! A sedução das tuas artes é ainda maior na pirarucuzição dos amigos e companheiros do que dos inimigos. Não é de arpão que os caça, ó divino pescador senão com doces fluídos com que os envolves para trazer os grandes peixes do rio-mar até esse viveiro tranquilo, onde os tens, aligeiros e saltitantes, à espera das tuas mandíbulas generosas. A tua vocação, o teu destino de pescador triunfam sobre o martírio de Oswaldo e a decepção de Flores. Não falemos nesta hora de tirania de déspotas. Como homem de espírito, louvemos a graça e a astúcia do Chefe do país (OESP, 15/04/1937, p. 13).

A partir do mês de junho de 1937, com os candidatos que concorreriam ao pleito já definidos e o posicionamento de Getúlio Vargas - favorável à candidatura José Américo de Almeida - também definido, a campanha eleitoral é intensificada. $A$ estratégia do pensamento armandista para ganhar a eleição presidencial também é melhor desenhada e apresentada. Palavras como "democracia", "era democrática", "salvação", tornaram-se centrais em sua campanha. A matéria "Com Armando de Salles Oliveira inicia-se no país a era democrática" foi a capa do primeiro número d'O ESP em junho de 1937, seguida de um apelo para que a nação tomasse conhecimento de que Armando de Salles Oliveira era o único capaz de manter a ordem e de assegurar a democracia. 
Armando de Salles Oliveira é hoje a expressão mais legítima da alma livre do Brasil. Mais do que ninguém sabe que a intranquilidade da nação não está em jogo no caso. $E$ melhor que ninguém saberia faze-la respeitar, se porventura alguém a esquecesse, porque ninguém mais que ele interessado num pleito livre em urnas livres e invioláveis. Inauguramos com Armando de Salles a era da democracia. Isto que o povo brasileiro começa a compreender nesta campanha de reeducação democrática para o qual o convocamos (OESP, 01/06/1937, p. 1).

Naquele momento, o Partido Constitucionalista trabalhava em prol do aumento do quadro eleitoral, incentivando os alistamentos. Para tanto, era necessário apelar para imagem de Armando de Salles Oliveira como um salvador da democracia, investindo nos medos vividos entre 1935 e 1936, como o do perigo comunista, todavia, por traz das apelações, sublinhava-se que o medo maior dos paulistas era justamente o de que Getúlio Vargas ferisse a Constituição, ao prorrogar seu mandato.

Os artigos de Assis Chateaubriand eram os que mais denunciavam o comportamento de Getúlio Vargas, que estaria articulando meios de impedir o sucesso da candidatura paulista, ou melhor, da candidatura de Armando de Salles Oliveira. Afinal, o argumento era o de que já não existia uma candidatura paulista, mas sim uma candidatura nacional. Já no início de junho, ao observar a aproximação entre Getúlio Vargas e o Partido Republicano Paulista, Assis Chateaubriand especula os motivos da aproximação.

Interroguemos a qualquer moço educado na escola do PRP sobre o que significa a revolução de 30 . Ele repetirá a cruel, a desalentadora legenda do perrepismo: uma jornada de libertários devorados pela inveja da grandeza bandeirante. Nunca o PRP se elevou acima desse miserável refrão, que muitas vezes ouvi, sangrando o coração fraternal de brasileiro (CHATEAUBRIAND, 01/06/1937, OESP, p. 18).

O Partido Republicano Paulista decidiu apoiar a candidatura de José Américo de Almeida, a despeito das posições contrarias que defenderam durante a revolução de 1930. Mais uma vez, Getúlio Vargas se envolveu em uma aliança inesperada, a aproximação com o PRP, em prol de impedir a vitória armandista.

Pelo simples e exclusivo fato do PRP, que tem fome de posições, que quer aderir a todo o transe, lhe haver sufragado o nome na convecção dos governadores, que fez o incorruptível? Revogou dez discursos, vinte anátemas, trinta dúzias de frases de fogo, 
exclamando esta sentença que é a morte da sua mesma coerência, porque faz voar em estilhaços o bronze de frases lapidares, pronunciadas em dias memoráveis contra os verdugos da democracia e os energúmenos do regime:

- Não prevalecerá contra nós o efeito retroativo da intriga. Vamos para a frente que São Paulo será sempre o futuro. O tempo é pouco para voltarmos atrás. Em 1930 eu tinha um espírito de combate e o PRP tinha outro. Agora nós temos o mesmo espírito de paz e patriotismo por São Paulo e pelo Brasil. José Américo (CHATEAUBRIAND, 01/06/1937, OESP, p. 18).

A declaração é do candidato José Américo de Almeida, que precisava justificar sua improvável aliança com o Partido Republicano Paulista. Com o apoio a candidatura José Américo de Almeida, o Partido Republicano Paulista sofreu seguidas dissidências, partidários que se deslocavam para o candidato armandista e eram anunciados a todo tempo no jornal O ESP. O motivo? Ainda existiam aqueles que em São Paulo estariam ao lado dos que estivessem contra Getúlio Vargas. Foi assim em 1930, em 1932, em 1934 e se repetiria em 1937. Uma entrevista conduzida pelo O ESP com um grupo de estudantes da Faculdade de Direito da USP revela tal pensamento. Na ocasião, os estudantes apoiram a candidatura armandista justamente por Armando de Salles Oliveira estar sendo identificado, naquele momento, como o candidato que ia contra Getúlio Vargas.

A nossa primeira pergunta ao presidente do Grêmio Universitário do PRP sobre se ele e seus amigos apoiavam a candidatura do sr. Armando de Salles Oliveira, respondeu-nos o estudante Luíz Edmur Arantes Barreto:

- "Não há dúvida sobre isso. Éramos contra o sr. Getúlio Vargas; o PRP apoia hoje o sr. Getúlio; o sr. Armando de Salles Oliveira está contra o sr. Getúlio; ora nós ficaremos com o sr. Armando de Salles, com São Paulo. (OESP, 01/06/1937, p. 1).

Se na candidatura armandista se condensavam as aspirações democráticas do Brasil, ficar ao lado de Armando de Salles Oliveira também era ficar ao lado de São Paulo, o elemento regional persistia. São Paulo era o único capaz de fazer com que o Brasil continuasse. 


\subsection{A União Democrática Brasileira e sua importância na articulação da campanha presidencial}

Conforme apresentamos anteriormente, Getúlio Vargas, que a princípio parecia apoiar o movimento de renovação política vigente em São Paulo, distanciouse dele com a antecipação do debate sucessório, iniciativa que modificou o quadro político nacional. A saída de Armando de Salles Oliveira do governo de São Paulo confirmou as expectativas de uma candidatura paulista, dissociada do governo Vargas. Extraoficialmente, a campanha eleitoral já havia começado. No entanto, apenas depois de janeiro, data acordada entre Vargas e os interventores, a campanha eleitoral é oficialmente iniciada. Em junho de 1937 foi fundada a União Democrática Brasileira (UDB). A UDB contava com o mesmo núcleo político do Partido Constitucionalista, cujos membros decidiram formar uma concentração democrata que coordenasse as forças políticas que apoiavam a candidatura de Salles Oliveira (OESP, 04/06/1937, p. 1). Assim, a UDB foi instalada em 10 de junho de 1937. Segundo Armando de Salles Oliveira, a agremiação havia se formado espontaneamente, com a adesão de correntes políticas que apoiavam e sustentariam seu nome para a sucessão presidencial. Contava ainda com o apoio das dissidências de políticos e partidos de diversos estados, o que tornou a UDB oposição, e Armando de Salles Oliveira, candidato oposicionista à frente de uma força política de projeção nacional. Em discurso proferido no dia da instalação da agremiação, o candidato presidencial destacou justamente as razões do surgimento dessa força que se pretendia nacional, capaz de aglutinar um amplo apoio à sua candidatura:

A ideia nacional nunca nos abandonou, a mim e aos meus companheiros de $\mathrm{S}$. Paulo nas horas mais angustiadas da revolução de 1932. Naquele movimento não foi o sentimento regional, mas a própria alma do Brasil que se ergueu para reconduzir o país ao leito de suas tradições. O sacrifício de tantos homens heroicos nos dois campos de luta transformou-se afinal numa vitória da nação. Até os homens que jogaram a vida, combatendo contra os constitucionalistas, pronunciaram sua opinião definitiva sobre o caráter daquele episódio extraordinário. As sombras que sobre ele se tinham lançado já se vão dissipando e logo ficará apenas o fulgor intenso de uma verdade nobilitante: os revolucionários de 1932, que em suas fileiras contavam brasileiros de todos os setores do país, alimentavam-se de um móvel espiritual - a convicção de que se batiam pela sobrevivência do Brasil (OESP, 11/06/1937, p. 1). 
Significativamente, a dimensão nacional dessa força de posição é enfatizada. Armando de Salles Oliveira faz questão de distinguir a diferença entre essa e a do regionalismo, pecha lançada pelas forças legalistas à Revolução de 1932 e que permanecia acompanhando São Paulo e demais grupos políticos de oposição daquele estado. A formação da UDB fazia, assim, o papel de eixo do projeto de projeção nacional, tal como pensado por Armando de Salles Oliveira e seu grupo. O Partido Constitucionalista, quando fundado, em 1934, foi desdobramento da guerra de 1932, e teve seu nome cuidadosamente pensado para enfatizar a luta de São Paulo pela reconstitucionalização do país. Os paulistas, e aqui nos referimos principalmente ao grupo de Armando de Salles Oliveira, oriundos em sua maior parte do Partido Democrático, de 1924, buscavam ser identificados como defensores da democracia, da Constituição e, também, assim como Getúlio Vargas, da unidade nacional. Segundo matéria veiculada n'O ESP, em 1937:

Todas as tentativas de organização de partidos nacionais democráticos têm falhado porque em todas elas o que se visou foi mais a conquista imediata do poder que a execução de um programa de cuja necessidade estivessem todos profundamente convencidos, a fundação da UDB parece-nos, por isso, um dos acontecimentos mais importantes e mais animadores dos últimos tempos" (OESP, 04/07/1937).

De todos os enunciados, projeções e iniciativas daquele projeto, a questão da unidade nacional foi significada como fundamental e decisiva para concorrer à eleição presidencial. Daí a importância dessa agremiação partidária para dar sustentação à candidatura de Salles Oliveira, ancorada na imagem do nacional, , sem prejuizo, porém, quanto às expectativas de fortalecimento das federações. Como Salles Oliveira mencionou em seu prefácio para o livro Jornada Democrática (1937), as armas da Revolução de 1932 haviam sido trocadas pelas urnas, essa mudança expressava a ideologia do Partido Constitucionalista: a de regimes democráticos ancorados em sólidos e fortes partidos políticos nacionais. A partir do primeiro semestre de 1937, a empreitada eleitoral, conduzida agora pela União Democrática Brasileira - "três palavras cuidadosamente escolhidas" (CODATO, 2008, p. 90) -, tentará ganhar as eleições presidenciais. De acordo com Plínio de Abreu Ramos: 
Armando compreendera que não deveria ser o "candidato de São Paulo" ou o "candidato paulista", pois foi essa modalidade de identificação das candidaturas presidenciais na República Velha que levou o PRP à ruína. Ele desejava ser, com justa preocupação, um candidato nacional, de um partido nacional (RAMOS, 1980, p. 195).

No jogo político de lançamento de sua candidatura, tal zelo em ser reconhecido como "candidato nacional" evidencia-se nas ações implementadas para tal. Além do Partido Constitucionalista, a agremiação contou com diversos e diferenciados partidos regionais, que apoiavam a candidatura de Armando de Salles Oliveira; o Partido Republicano Mineiro, o Partido Republicano Liberal do Rio Grande do Sul, a Frente Única Paraense, a Concentração Autonomista da Bahia e o Partido Republicano da Bahia. Posteriormente, a UDB recebeu adesões do Partido Social Democrático do Ceará, chefiado por Fernandes Távora; da União Progressista Fluminense, chefiada por Pedro Kelly; da Legião Republicana Catarinense, de Rupp Júnior; da União Republicana Paranaense, chefiada por Ivo Leão; Partido Liberal do Paraná, chefiado por Idálio Sardenberg; e da Aliança Democrática Paranaense, chefiada por Artur Santos. A agremiação recebeu ainda o apoio isolado de políticos em emergência no cenário político regional e nacional, como Café Filho, do Rio Grande do Norte; Alfredo Nasser e Ramos Caiado, de Goiás; de Agostinho Monteiro, do Pará; de Eurico Sousa Leão, de Pernambuco; de Arnon de Melo, de Alagoas; e de Raul Fernandes, do Rio de Janeiro (RAMOS, 1980). O bloco aglutinava forças de diferentes matizes, propostas e interesses de diversas regiões do país e, em sua diversidade, compartilhava um aspecto em comum: a oposição do governo Vargas e o desejo de virar o jogo político. Aportavam, por isso, em suas capacidades de aglutinação político-partidária e em sua força política local e regional em crescimento.

Durante a reunião de fundação da UDB, seus mentores fizeram questão de destacar o caráter nacional daquela agremiação. Para liderança da UDB, nas duas casas do Congresso, foram escolhidos os nomes de João Carlos Machado, deputado do Rio Grande do Sul, e Paulo de Morais Barros, senador de São Paulo. Entre seus objetivos estavam o de, através de um grande partido nacional, coordenar as forças políticas regionais. O desafio, como se vê, era grande; a ambição talvez desmedida para a cultura partidária da época. Em 3 de julho de 1937, o jornal O ESP, investindo nesse projeto, publicou, em sua capa, matéria 
sobre a fundação da UDB, apresentando o respectivo estatuto. O novo partido era formado por três órgãos: o Congresso, responsável por exercer as atribuições a cargo da convenção; o Diretório Nacional, que tinha poderes de representatividade externa do partido; e a Comissão Executiva, que levava à prática a aplicação do programa partidário. Os principais pontos do programa partidário da UDB, resumidos por Otávio Mangabeira, que os denominou "evangelho da União Democrática Brasileira", apontam para aquela ambição política, pretensiosa demais ante práticas arraigadas, refratárias à modernização e democratização contidas no projeto.

1. Democracia, com a manutenção do voto secreto, justiça eleitoral, pluralidade partidária e sistema de representação proporcional; 2. defesa das liberdades públicas; 3 . preparação política do povo pela educação; 4 . defesa do regime federativo; 5 . preservação da intocabilidade da carta de 16 de julho; 6 . observância das regras do jogo democrático (RAMOS, 1980, p. 197) ${ }^{63}$

Com a fundação da União Democrática Brasileira, o projeto político do grupo armandista vai precisando seus contornos. Em discurso proferido durante a campanha presidencial, em outubro de 1937, no Rio de Janeiro, Armando de Salles Oliveira destaca o papel que a União Democrática Brasileira deveria desempenhar em seu futuro governo: o de criar um "robusto laço entre os Estados", respeitando o pacto federativo, ao assegurar a autonomia destes frente à União, sem que esta perdesse sentido e posição de centralidade no sistema político brasileiro. Nas palavras de Salles Oliveira:

A Federação, no Brasil, é uma fatalidade política, conservada pela convergência de fatores históricos, econômicos e sociais, que derivam das origens da nacionalidade. É a condição fundamental da unidade brasileira. A história republicana está, porém, diante de nós para mostrar que alguma falha existe em nosso organismo político para que ainda persista o espírito intervencionista que, lacerando a autonomia dos Estados, fere a Federação em seu princípio vital.

Formada pela comunidade de aspirações do país, a União Democrática cria um robusto laço entre os Estados e será uma arma eficaz, que não só se empregará contra os abusos do poder, como servirá para corrigir as desigualdades na importância política dos Estados. Onde apareça um interesse digno de amparo de um Estado de pequena representação, o partido nacional logo o faz seu apresenta-se para defendê-lo. Com esse objetivo, a União Democrática vai elevar e fortalecer o ideal federativo, concorrendo para que todos os brasileiros se sintam bem, dentro da inevitável

63 O documento original do Estatuto de fundação da União Democrática Brasileira e a Lei Orgânica da agremiação encontram-se no Arquivo Paulo Duarte, no Instituto de Estudos de Linguagem da Unicamp. (PD/ASO - p.37 (220). 
diversidade de condições econômicas de nosso imenso país (OLIVEIRA, 1937, p. 33-34).

O papel da União Democrática Brasileira seria, portanto, o de corrigir as distorções nas relações entre a União e Estado, de estabelecer a unidade nacional, sem prejuízo, porém, da autonomia dos Estados, sem ferir o "princípio vital" da federação. A crítica é direta contra os "abusos de poder" da centralização do governo Vargas, contrapondo essa orientação com a do real fortalecimento do "ideal federativo", na contra mão portanto da política e do pensamento de Getúlio Vargas. É justamente contra essa proposta desenvolvida pelo grupo político de Armando de Salles Oliveira e daqueles que a apoiavam, que Getúlio Vargas se posiciona, desrespeitando as regras do jogo político, ao instaurar o Estado Novo, cujo compromisso era a preservação da unidade brasileira e a modernização conservadora e centralizadora do Estado Nacional. Futuramente, quando da instalação do Estado Novo, a rejeição de Vargas pelas autonomias estaduais, explicita-se publicamente logo no início do regime, com o episódio da queima das bandeiras, ato espetacular que simboliza sua orientação e investimento na construção do nacional. Com efeito, em 27 de novembro de 1937, menos de um mês após o golpe que instalou o Estado Novo, por ocasião do dia da bandeira ${ }^{64}$, Getúlio Vargas realizou um ato comemorativo no qual foram hasteadas 21 bandeiras nacionais, substituindo as bandeiras estaduais que foram, em seguida, queimadas, ao som do Hino Nacional. O objetivo do evento era, por meio de ato pirotécnico, mostrar e ensinar ao povo brasileiro a reconhecer e valorizar "a força e a supremacia do nacional sobre o regional, expondo a fraqueza do pacto federalista da "Primeira República”, agora designada como "República Velha”." (SILVA, 2014, p. 36).

\subsection{Nem do norte, nem do sul: a hora é do Brasil}

Dirigindo-se ao governador de Pernambuco o eminente candidato governamental disse, em um transporte de efusão lírica, que "a hora

\footnotetext{
${ }^{64} \mathrm{O}$ dia das bandeiras foi celebrado excepcionalmente no dia 27 e não no dia 19, em acordo com o calendário cívico brasileiro, devido às condições climáticas ruins. Vargas registrou o episódio em seu diário (VARGAS, 1995, p. 85-87). O episódio foi a primeira cerimonia cívica realizada após o golpe que instalou o regime do Estado Novo, em 10 de novembro de 1937 (PAIVA, 2015).
} 
é do Norte". Tocamos aqui na raiz do que desde muito antes da candidatura José Américo venho combatendo: o bloquismo regionalista.

$[\ldots]$

A hora não é do Norte, e muito menos do Sul. A hora é do Brasil, apenas do Brasil, exclusivamente do Brasil. E o dono da hora do Brasil, sinto dize-lo a um brasileiro de enormes serviços prestados à sua pátria como o sr. José Américo, é sr. Armando de Salles Oliveira. Tanto tem de espontânea a candidatura deste, como de artificialmente criada a do grande general da campanha das secas. Um brotou da zona livre dos sentimentos, das afeições, das emoções e da sensibilidade do povo. A outra nasceu da conspiração de políticos precisamente para abafar aquela (OESP, 02/06/1937, p. 14).

Assis Chateaubriand, em seu artigo "A hora é do Brasil”, reforça a ideia de combate aos regionalismos em favor do nacional, força maior, aglutinadora e impulsionadora do progresso do país. Passados sete anos da vitória da revolução de 1930, que havia anunciado o propósito de acabar com as velhas oligarquias regionais e seus vícios em fazer política pautada em interesses estritamente regionais, o tema dos regionalismos ainda estava presente e assombrava. Principalmente a força de São Paulo, que sempre ergueu com orgulho regional a bandeira de "locomotiva" da nação. Antes da revolução de 1930, São Paulo portava a imagem de estado mais importante do país, que carregava as demais federações como peso.

Segundo Ilka Stern Cohen (1997), o grupo político de Salles Oliveira arquitetou uma estratégia de campanha eleitoral, na qual buscava-se disseminar um modelo de governo capaz de retirar o Brasil da crise política em que se encontrava. Crise, essa, creditada a um suposto "perigo vermelho", "perigo verde", e uma possível volta à ditadura, conduzida por Vargas. Paradoxalmente, ao defender seu projeto político, forjado em um modelo político capaz de salvar o Brasil, o discurso armandista se aproximava justamente do discurso do Estado Novo, de seu maior opositor, Getúlio Vargas. Como ressalta Cohen:

Ao longo de seu governo, rodeado dos mais expressivos intelectuais paulistas, Armando de Salles Oliveira vai forjando um modelo político que, embora guarde algumas relações com o mais clássico liberalismo, em muito se aproxima do discurso do Estado Novo ao defender valores como ordem, autoridade e hierarquia, entendidos como princípios básicos de ordenamento social. Os fundamentos dessa representação encontram seu mais forte argumento na busca 
de uma nova racionalidade, capaz de produzir mecanismos de administração eficientes e neutros. O engenheiro Armando de Salles tem em seu curriculum uma bem sucedida carreira em empresas de eletricidade e na Companhia Mogyana, o que Ihe confere o caráter empreendedor bem ao gosto da época (COHEN, 1997, p. 189).

Com efeito, além do nacional, os discursos de Armando durante a campanha eleitoral enfatizavam a ação empreendedora, a administração eficiente, e neutra, marcas de uma nova racionalidade na gestão da coisa pública. Não por acaso, divulgar nesses discursos sua experiência à frente de São Paulo, seu empreendedorismo, sua capacidade técnica, administrativa e política. O objetivo era transmitir ao país uma imagem de governança que deu certo, que foi eficiente, que era moderna, portanto, modelar.

Ao atribuir ao progresso material um caráter de defesa dos interesses de São Paulo e do Brasil, desaparecem seus beneficiários diretos e surge em seu lugar a população paulista como um todo, encobrindo a dimensão de conflitos presente nas relações sociais. Transpondo-se essa percepção para a questão da política, essa passa a ser vista como a arte de administrar eficientemente, de modo que os critérios de legitimidade se reduzem ao bom desempenho da tarefa da administração pública. Tal imagem projetada para o Brasil acaba por erigir um modelo político fundado na busca de homogeneidade e anulação das diferenças, de modo a traçar uma única via possível para a solução dos problemas nacionais. E na luta política essa única possibilidade se cristaliza na pessoa do candidato Armando de Salles Oliveira. Não é por acaso que o volume que reúne seus discursos de campanha tenha como título "Para que o Brasil continue" (COHEN, 1997, p.190).

A expressão "Para que o Brasil continue" foi utilizada no desfecho de um dos discursos proferidos por Armando de Salles Oliveira, já nos meses finais da campanha eleitoral de $1937 .^{65}$ Sem qualquer modéstia, ele defende que a condição para que o Brasil continuasse era entrega-lo à direção dos paulistas, especialmente o paulista Salles de Oliveira. O político investe em sua própria imagem e na de São Paulo como estado dinâmico e eficiente à frente dos demais estados da União. Distanciando-se da imagem de locomotiva, investia-se agora na imagem de espelho que refletia o "espírito da democracia, intrínseca no caráter nacional" (COHEN, 1997, p. 28), representativa de São Paulo, "portador de um projeto nacional". A

\footnotetext{
${ }^{65}$ O discurso também está publicado no livro Jornada Democrática.
} 
respeito da campanha política executada pelo grupo político de Armando de Salles Oliveira, Ilka Stern Cohen faz interessante avaliação:

Toda estratégia do discurso de campanha aponta no sentido de demonstrar que a democracia no seu sentido mais "puro" só poderia ser defendida por um paulista, o que remete a uma determinada imagem de democracia que, no Brasil, só a São Paulo corresponde. Novamente é São Paulo o portador de um projeto nacional, cristaliza o espírito da democracia, intrínseca no caráter nacional. (Idem, p. 228).

Concordamos com a autora, existiam essas duas preocupações perpassando os discursos pronunciados pelo candidato paulista: a de apresentar São Paulo como modelo de administração bem sucedida e portador de um projeto nacional e a de representar São Paulo como fiel ao princípio federativo, como unidade integrante da nação, repudiando a imagem de um candidato preocupado somente com interesses regionais. Na pesquisa feita com a imprensa sobre a campanha eleitoral, encontramos as duas preocupações bem ressaltadas. Já o jornal $O E S P$, de circulação interna, cuidava de inflar o ego do eleitor paulista ao anunciar que estenderia a toda nação o modelo de administração pública paulista , da gestão Salles Oliveira, o único capaz de conduzir o país. A imprensa de circulação nacional, mantinha postura mais contida em demonstrar essa exaltação regional, de modo a angariar a simpatia nacional. No discurso estrategicamente pensado para o nacional, a imagem já consolidada no imaginário social de São Paulo como "locomotiva" do Brasil soava, àquele momento, arrogante, comprometendo possíveis adesões regionais, precisava assim ser esmaecida e até mesmo silenciada, caso quisessem ganhar apoio e as eleições.

Outro objetivo dos discursos de campanha era expor as mazelas associadas às forças concorrentes - extremismos da ANL e da AIB e ditadura varguista - em contraponto com os benefícios identificados com a administração realizada por Armando de Salles Oliveira, o único candidato capaz de fazer "o Brasil continuar". Observa-se, nesse jogo político, os usos e abusos que eram feitos em nome da "crise": assim como Vargas fez uso de uma suposta crise para articular seu continuísmo no poder, também o grupo armandista empregou-a para fundamentar sua condição para contornar a crise e governar o país. Segundo Cohen, os temas dos extremismos e da ditadura representaram um papel fundamental na construção 
da candidatura de Salles Oliveira, uma vez que "os liberais paulistas só podem emitir seu discurso se tiverem como contraponto os iminentes perigos da desordem e da desagregação" (1997, p. 276). Os dois adversários políticos, Vargas e Salles de Oliveira, investiram engenhosamente na crise para demarcar suas posições e angariar apoios políticos.

A solução para que o Brasil continuasse estaria, assim, na competência e experiência administrativa do grupo liderado por Armando de Salles Oliveira e dele próprio à frente do governo. Naquele contexto, a manipulação dos sentidos que povoavam imaginário político das representações extremistas foi astuciosamente operado nos discursos e ações da campanha do Partido Constitucionalista e da União Democrática Brasileira. Para se contrapor ao extremismo, de direita ou de esquerda, mobilizava-se, na imprensa e nos palanques, a imagem de autentico liberal, representada pelo candidato Salles Oliveira, ex-interventor no governo Vargas. Conforme avalia Cohen:

É com as credenciais de interventor bem sucedido à frente do governo do estado que Salles se apresenta como candidato ao Catete em inícios de 1937. [...] São Paulo é colocado como centro de irradiação de um projeto político modelar: progresso material, eficiência administrativa, e controle sob a ordem social. São Paulo é o futuro. A necessidade de reconquistar o espaço perdido depois de 1930 reafirma o discurso sobre identidade política paulista, calcada na manipulação das imagens de força, ousadia e persistência, cuja representação mais forte é a figura do bandeirante.

Arriscando uma analogia, pode-se dizer que é na mesma fonte em que se inspira a imagem da locomotiva: portadora do progresso, de um projeto de civilização, de ordem próprios. Desbravando. Transformando. Impondo um modo definido de ser. São Paulo é modelar, deve se transportar para dimensão nacional (COHEN, 1997, p. 222-223).

Entretanto, tanto no que diz respeito ao golpe de Estado articulado por Getúlio Vargas quanto à campanha de sucessão presidencial de Armando de Salles Oliveira, é importante ter em consideração que não são projetos prontos, pensados com um início, meio e fins certos. São projetos em processo, isto é, vão sendo construídos à medida que o jogo político se desenvolve, em meio à luta pelo controle do poder. Justamente por isso, por vezes, os discursos armandista e varguista às vezes se encontram, outras se confrontam, outras se alinham, outras se 
contradizem. Cada um, no campo político que se localiza, precisa se adaptar às exigências e expectativas do momento, de modo a ter recepção. É justamente essa fluidez, essa "dinâmica que permite explicar a mescla de tendências que se manifesta nos diferentes discursos, e é no campo da política que se institucionalizam as propostas vitoriosas" (COHEN, 1997, p. 279).

O jornal O ESP enfatizava que a candidatura de Salles Oliveira era a única candidatura nacional, que defenderia os interesses do país todos, enumerando os feitos da administração armandista. Já o candidato José Américo de Almeida investia no viés regionalista em sua campanha, ao discursar que havia chegado a hora da região norte ter vez à frente da política do país, na contramão das propostas nacionais. O jornal O ESP explorava esse viés do discurso de José Américo de Almeida, ressaltando que ele tinha o tom de promover intrigas entre os estados, algo que deveria ser superado. Segundo avaliação do referido jornal,

Quem enfrentou os germes da desagregação nacional, deixados na alma dos paulistas pelos erros da Revolução de 30? Quem se levantou contra as tendências dissociativas da nacionalidade, açuladas na surdina, como arma política, pelos partidos contrários à administração paulista? Quem traçou, com pulso firme, as grandes avenidas econômicas que hão de levar S. Paulo e o Brasil aos vales fecundos da prosperidade? Quem deu as bases das reformas sociais feitas dentro das tradições da vida brasileira, sem assomos violentos de ódios? Quem, dentro de S. Paulo, arrostando e desprezando os meneios de uma falsa e perigosa popularidade, teve a coragem de colocar o rumo de nossa vida no seu roteiro eterno? Quem fez da democracia um apostolado, quando os seus princípios, ameaçados, pareciam condenados a um violento eclipse? Quem enfrentou os extremismos, em discurso público, cujas repercussões em todos os cantos do Brasil foi um dos acontecimentos mais memoráveis dos últimos tempos! Armando de Salles Oliveira. (OESP, 08/08/1937, p. 19).

Apenas um candidato apresentava perfil político e administrativo capaz de responder a todos estes desafios: o nome era um só, o paulista Armando de Salles Oliveira.

\subsection{O golpe se aproxima. A ação política do grupo armandista}

O golpe do Estado Novo foi planejado e sua execução bem sucedida dependeu, principalmente, mas não exclusivamente, da adesão do Exército à tese 
de que o comunismo voltaria a atacar. Mas algumas medidas precisaram ser tomadas antes da execução dos planos. Para fechar o Congresso e instaurar a ditadura foi preciso, antes, eliminar uma eventual oposição dos estados do Rio Grande do Sul, São Paulo e Bahia. Dessa forma, Getúlio Vargas não feriria os direitos dos Estados federados. Como sublinha Ferreira, a disputa política envolvia dois fortes jogadores, "União versus federação, em suma. Além de iniciar o cerco de São Paulo a partir de Minas Gerais". (FERREIRA, 2007, p. 146). A decretação do "estado de guerra" foi dispositivo legal indispensável para esvaziar o cenário de campanha eleitoral que já fora iniciada e estava sendo implementada, contrariando os propósitos de Vargas. O "estado de guerra" foi decretado por duas vezes, primeiramente em 1936, depois da Intentona Comunista e, novamente, em 1937, concomitante à agitação causada pela à crise e confronto com Flores da Cunha no Rio Grande do Sul, no calor da campanha sucessória e da descoberta de um mirabolante plano, o Plano Cohen ${ }^{66}$. É Góes Monteiro quem conduzirá os planos a serem executados.

Em junho de 1937, os líderes das bancadas e o Ministro da Justiça, José Carlos Macedo Soares, decidiram pela sustação do "estado de guerra", dispositivo que havia sido prorrogado ininterruptamente desde o levante comunista. Entretanto, em outubro daquele ano, a pretexto do Plano Cohen e da iminência de outra tentativa de golpe comunista, um novo decreto de estado de guerra foi votado. Desta vez, apenas as bancadas de São Paulo e do Rio Grande do Sul votaram contra. Naquela ocasião, o Rio Grande do Sul estava em luta declarada com o governo federal e a bancada paulista, composta por maioria constitucionalista, apoiava Armando de Salles Oliveira à presidência. (CAPELATO; PRADO; 1980). Pelo conteúdo dos editoriais do jornal O ESP, podemos inferir também que, desde julho daquele ano, a suspeita de um possível golpe de estado por parte do Getúlio já circulava entre os apoiadores da candidatura armandista. Vargas foi novamente bem hábil ao desarmar os liberais com a questão do comunismo. O jornal $O E S P$ acolheu, pela primeira vez, com reservas, a questão do estado de guerra, temendo que mais essa promulgação não passasse de uma manobra política para adiar ou

\footnotetext{
${ }^{66}$ De acordo com Oliveiros Ferreira, "o Plano Cohen foi apenas um pretexto para que se desse o golpe de 1937. Serviu para reforçar na opinião pública, menos acostumada a julgar documentos deste tipo, o sentimento de temor de uma nova tentativa de assalto comunista ao poder - conspiração montada peça por peça pelo General Góes Monteiro" (FERREIRA, 2007, p. 179).
} 
impedir as eleições presidenciais. Na ocasião, o General Dutra declarou que a medida foi solicitada ao Congresso apenas como precaução, uma medida de combate ao comunismo. O ESP, mais uma vez, faz discurso em tom conciliatório com o governo no que diz respeito ao combate ao comunismo, agenda que o jornal defendia:

Para combater o comunismo não recusaremos do governo todas as providências que a Constituinte permite. Uma vez que o estado de guerra não tem a mínima finalidade política e que, apesar dele, a campanha presidencial poderá continuar no ritmo que já tomou, é natural que esmoreçam as apreensões do primeiro momento". ( $O$ ESP, 07/10/1937, apud PRADO; CAPELO; 1980, p. 65).

Prado e Capelato apontam as contradições no discurso do jornal e como este teria ficado refém da luta contra o comunismo, com o ônus de acabar beneficiando Vargas e seus planos continuístas em detrimento do projeto de sucessão presidencial via eleições democráticas. Entendemos, porém, que o combate ao comunismo era uma bandeira comum aos políticos liberais do período, aglutinados em torno do grupo armandista e também do varguista, independentemente de suas orientações mais ou menos democráticas. Igualmente, não percebemos como erro de estratégia ou ingenuidade por parte do jornal O ESP e dos armandistas. Com efeito, à medida que o grupo armandista e Vargas se distanciam, o jornal abre espaço para críticas mais diretas e incisivas contra o governo Vargas; não há mais espaço para contemporizar, forjar alianças, compor acordos entre os dois adversários políticos, outrora aliados.

Em seguida à decretação do novo período de estado de guerra, Vargas exigiu que o comando da Brigada Militar do Rio Grande do Sul deixasse de se submeter ao governador de Flores da Cunha para se submeter diretamente ao comandante da região militar. A intervenção no Rio Grande do Sul foi decretada em 19 de outubro de 1937. Dali em diante os acontecimentos foram rápidos. Flores da Cunha renunciou no dia seguinte e deixou o país, auto exilando-se no Uruguai. $O$ Ministro da Justiça, José Carlos Macedo Soares, tantas vezes apontado como marionete de Vargas nos artigos de Assis Chateaubriand, demitiu-se de seu cargo em 5 de novembro, Francisco Campos tomou posse daquele ministério em 9 de novembro, e no dia seguinte foi dado o golpe de estado. 
Segundo Capelato e Prado, com o golpe, "ruíam silenciosamente as pretensões de "O ESP" de levar ao poder, pela primeira vez, um candidato cujo programa político traduzisse seu pensamento" (1980, p. 65). De fato as chances de Armando de Salles Oliveira e seu grupo alcançarem a presidência da república e executarem o seu projeto político, que fora iniciado em São Paulo, ruíram. Mas não silenciosamente, se considerarmos que o jornal já vinha veiculando a possibilidade de um golpe de estado cerca de três meses antes do mesmo ser desferido. Se também considerarmos que Armando de Salles Oliveira recusou-se a compor com Getúlio Vargas para prorrogação dos mandatos, não foi uma resistência silenciosa. Ocorre que Vargas tinha conseguido construir e alicerçar alianças mais fortes, além do apoio militar do exército, peça fundamental para o sucesso do golpe, como o próprio Paulo Duarte reconheceu em suas memórias.

Segundo as autoras, o jornal já mantinha uma posição anticomunista em seus editoriais mesmo antes da revolução de 1930. As autoras avaliam que, com o golpe de 1937,

\begin{abstract}
Atingimos assim o final de um período em que se pode assistir ao esboroar das perspectivas liberais do periódico, vítima de suas próprias contradições, aguçadas pelo temor do comunismo. A conduta de Armando de Salles Oliveira, cujos programas e pronunciamentos fundamentam-se no respeito sagrado à Constituição - sustentáculo da democracia - é objeto do mais caloroso aplauso do jornal. Por outro lado, com o advento do levante comunista, o jornal faz uma série de graves concessões, abrindo na cerrada muralha liberal largas brechas cuja tendência é aprofundarse cada vez mais. As arbitrariedades de Vargas são aceitas sem restrições, a mesmo tempo que "OESP" apoia e louva um candidato cujo caminho se pauta pelo respeito à legalidade. Enredados na malha das próprias contradições, o golpe atinge esses liberais, derrubando-os sem muito alarde, mas com extrema eficácia. (1980, p. 65-66).
\end{abstract}

Com efeito, as "graves concessões" feitas pelo O ESP abriram brechas na "cerrada muralha liberal", abrindo espaço para aceitação das arbritariedades de Vargas, cujo golpe de Estado acaba por atingir os liberais defensores da Constituição e da democracia. Nunca saberemos se o grupo liberal tivesse combatido com veemência as medidas varguistas, o desfecho teria sido diferente.

No livro "Diagrama de Uma Situação Política", foram reunidos manifestos políticos escritos por Armando de Salles Oliveira, a começar por aquele que, lido no 
Parlamento, antecipou o golpe de Estado de novembro de 1937, que instaurou no Brasil o regime ditatorial que vigorou por sete anos. Os outros escritos foram pensados e redigidos durante o período de exílio vivido pelo político paulista. O título para o livro póstumo foi retirado de um desses escritos, e a obra só pode ser publicada em junho de 1945, com o fim da censura imposta pela ditadura do Estado Novo. Foi essa a fonte que usamos para conhecer o pensamento político de Armando de Salles Oliveira e de seu grupo, bem como a memória dos acontecimentos políticos segundo a visão de um político derrotado e exilado. Em 8 de novembro de 1937, Armando de Salles Oliveira se reuniu com seus correligionários no Diretório da União Democrática Brasileira, onde leu um documento intitulado "Manifesto aos Chefes Militares do Brasil", que teve a unanime aprovação dos integrantes do partido. O manifesto foi lido na Câmara dos Deputados e no Senado Federal, em suas sessões de 9 de novembro de 1937. Leuo, na Câmara dos Deputados, João Carlos Machado, representante do Rio Grande do Sul, e no Senado Federal, Paulo Morais de Barros, representante de São Paulo. O governo do Rio Grande do Sul, em aliança com o governo de São Paulo, apoiava a realização das eleições presidenciais e candidatura de Armando de Salles Oliveira.

Consideramos elucidativo investigar a posição e ação dos membros do Partido Constitucionalista nesse momento da ofensiva de Getúlio Vargas. Já as vésperas do movimento golpista, o apelo de Armando de Salles Oliveira aos militantes soa mesmo patético. Abandonado em termos de apoio político de outros Estados da federação, desarmado, restou ao candidato derrotado, o amargo caminho do exílio. O conteúdo do manifesto de Armando de Salles Oliveira chega a ser comovente, como expressão sincera de seu pensamento, de seu ideário político e, sobretudo, de sua amargura e impotência diante do golpe:

As palavras que nesta carta dirijo aos chefes militares, são o profundo e veemente apelo de um brasileiro sincero, cheio de emoção e de amargura diante do panorama nacional. Serão um grito de desespero, se quiserem, mas que, pelo seu puro acento, não poderá deixar insensíveis os que o escutarem: nele se exprimem as inquietações dos que sentem que outros graves perigos, além do comunismo, conspiram contra o Brasil. Se alguma força poderosa não intervir a tempo de impedir que se cumpram os maus pressentimentos que hoje anuviam a alma brasileira, um golpe terrível sacudirá de repente a nação, abalando os seus fundamentos até as últimas camadas e mutilando cruelmente as suas feições aqueles traços conhecidos que, através dos tempos, se vêm 
incorporando na essência de nossa formação moral (OLIVEIRA, 8/11/1937, 1945).

Armando de Salles Oliveira escreveu o manifesto como uma última jogada, uma ultima tentativa em tentar dividir os militares:

Pela primeira vez em nosso país, um partido de oposição, confiante na opinião popular, suplica que se cumpra a lei eleitoral, ao passo que, nos domínios governamentais, se trama contra ela. Para mim e para o meu partido, o voto, assegurado pela lei atual, continua a ser a melhor expressão da altivez brasileira. Com esse voto a nossa vida cívica tinha adquirido uma dignidade antes desconhecida. Impedir, frustrar ou viciar o voto, para nós, é violar a dignidade do Brasil. Para a defesa de nossas ideias e a conquista do voto, dispúnhamos sobretudo de uma arma - a palavra. Empreendendo uma campanha de propaganda que era ao mesmo tempo uma obra saudável de educação cívica, realizamos comícios políticos que, pela altura dos discursos, pela sinceridade dos propósitos, pela inteligência e pelo fervor patriótico das multidões, pela ordem e pelo brilho, se comparavam às grandes demonstrações coletivas das maiores nações. Era, sem dúvida, um espetáculo inédito e comovedor ver, por exemplo, dois brasileiros como os Srs. Arthur Bernardes e Antônio Carlos, encanecidos na vida pública, tendo passado pelos seus mais altos postos, virem para rua, com puro desinteresse, e pedirem diretamente ao povo o seu auxílio para a preservação dos princípios democráticos (OLIVEIRA, 08/11/1937, 1945).

Neste trecho, Armando de Salles Oliveira destaca os elementos utilizados por seu grupo político durante a campanha eleitoral para mobilizar, nacionalmente, o eleitorado e alcançar a vitória nas eleições. Os comícios políticos tiveram lugar de destaque na campanha eleitoral do grupo político armandista. O jornal O Estado de S. Paulo fazia questão de cobrir e publicar sobre os apoios regionais dados ao Partido Constitucionalista sempre que Armando de Salles Oliveira saía em caravana promovendo comícios. Este candidato tomava para si e seu grupo político o compromisso de se pautar por um comportamento "inédito e comovedor" em relação à dos políticos tradicionais que, em eleições anteriores, não se preocupavam em dialogar com o eleitorado, em ir às ruas em busca dos votos dos eleitores. Afinal, no jogo existente, suas candidaturas estavam, de antemão, vitoriosas graças às fraudes eleitorais. Na avaliação de Armando de Salles Oliveira:

Generaliza-se a convicção de que não haverá eleições a 3 de janeiro. Multiplicam-se com engenho fértil os pretextos de não cumprir a obrigação constitucional. Na sombra em que os comunistas urdem os seus planos de conquista, agem igualmente outros homens que, decretando por conta própria a falência da democracia 
brasileira, nas vésperas do dia em que ela ia oferecer a prova insofismável de sua vitalidade, procuram converter os meios de extermínio, usados contra o bolchevismo, em armas de destruição do regime. Só não vê claro que não quer. Está em marcha a execução de um plano longamente preparado, que um pequeno grupo de homens, tão pequeno que se pode contar nos dedos de uma só mão, ideou para escravizar o Brasil (OLIVEIRA, 08/11/1937, 1945).

Após tomar conhecimento do ocorrido, Getúlio Vargas registrou em seu diário, em 9 de novembro de 1937, sua avaliação da repercussão do documento, junto ao Exército, com a possibilidade de divisão entre os integrantes dessa corporação:

[...] já é noite, tive conhecimento de que a carta do candidato Armando Sales, lida na Câmara pelo deputado João Carlos Machado, fora profusamente espalhada entre os militares. Pedi ao Macedo que fosse ao Ministro da Guerra, e este ao palácio, para confirmar-me não só que a data do movimento marcado para quintafeira, 11, já estava conhecida, como se estava fazendo um trabalho de intriga e divisão dos militares. Em vista disso, era preciso precipitar o movimento aproveitando a surpresa. E assim se fez (VARGAS, 1995, p. 82-83).

Decisão tomada e executada, de modo precipitado, para aproveitar o elemento surpresa. Com efeito, no dia seguinte, 10 de novembro de 1937, as duas casas do Congresso amanheceram guardadas pela polícia. Na noite desse mesmo dia, Armando de Salles Oliveira foi detido em sua residência, transferido para outras residências forçadas em Nova Lima e Rio de Janeiro, até outubro de 1938, quando o novo domicílio que lhe havia sido destinado era o exílio político.

Após o anúncio do Plano Cohen, no dia primeiro de outubro, o Ministro da Justiça pediu a decretação do "estado de guerra". A bancada da União Democrática Brasileira marcou sua posição, votando em peso contra o "estado de guerra": 138 votos a favor contra 52 , sendo aprovada pela Câmara a proposta. O senado fez o mesmo por 23 votos a favor contra 5. Ocorre que o choque de uma possível sublevação veio somar-se à crise sucessória, agravada com o rompimento entre Flores da Cunha ao governo Vargas, e com a oposição daquelas, bem com com o lançamento da candidatura de Armando de Salles Oliveira à Presidência da República, em fins de 1936. Conforme vimos com a leitura dos diários de Vargas, Flores da Cunha, na oposição, atuou no sentido de precipitar a discussão sobre a sucessão presidencial. Esta posição do político gaúcho traduzia sua discordância 
com Vargas quanto aos rumos do país, o que levou finalmente ao rompimento entre os dois, com seus desdobramentos para o cenário político nacional (FERREIRA, 2007). Tal ruptura ocorre não apenas pelo fato de o governador gaúcho forçar uma precipitação do debate em torno da sucessão presidencial, mas também por sua insistência em articular a candidatura de Armando de Salles Oliveira, trazendo seu nome para o debate nacional sobre a sucessão presidencial e convocação das eleições.

Resta-nos perguntar se não teriam os paulistas igualmente aderido a uma espécie de elitismo ao se afirmarem como única alternativa possível. Para Cohen, a proposta armandista foi autoritária pela sua "disposição de se auto definir como a única solução para a questão nacional". Em sua avaliação:

Pode-se afirmar, diante de tais palavras, que o caminho para o autoritarismo não foi aberto apenas pelas concessões às medidas institucionais de exceção, como o estado de sítio e a lei de segurança nacional. Foi aberto pela disposição de se auto definir como a única solução para a questão nacional, além da presunção de que é possível controlar indefinidamente os mecanismos de controle social. É nesta dimensão que se pode entender a estratégia política dos liberais paulistas (COHEN, 1997, p. 207-208).

Como vimos, Armando de Salles Oliveira participou imediatamente do debate sucessório, tendo se afastado do governo em fins de 1936, quando começa a promover sua candidatura à presidência da República para as eleições de 1938 . Tal iniciativa, vista por Vargas como precipitada, responde pelo descontentamento do presidente que, por conta disso, agia no sentido de esvaziar o debate sucessório. De acordo com Oliveiros Ferreira, "da repressão à Intentona até o golpe de Estado, em 1937, assiste-se a um complicado jogo". Dentre seus protagonistas encontra-se Armando de Salles Oliveira e sua candidatura à presidência da República, que precipitou os acontecimentos, ou melhor:

Permitiu que as nuvens que se adensavam no horizonte ganhassem forma. A Locomotiva começara, assim, no primeiro semestre de 1936, a descer o plano inclinado do golpe. A sucessão presidencial as eleições seriam apenas em janeiro de 1938! - começou cedo a agitar não apenas os meios políticos, mas também os militares. As intrigas fervilhavam em toda parte (FERREIRA, 2007, p. 158-159). 
Armando de Salles Oliveira e o grupo político do jornal O Estado de $S$. Paulo, são atores e também peças importantes no jogo político nacional que resultou no golpe de 10 de novembro de 1937. De modo que investigar sua atuação na deflagração do golpe do Estado Novo é uma possibilidade de conhecer o pensamento e a ação dos armandistas, traduzidos em um projeto político de dominação nacional sob a égide das elites políticas de São Paulo.

A unanimidade da imprensa refletia o pânico motivado pelo golpe comunista. O envolvimento com a internacional comunista ensejava o cumprimento de um dever: todo o poder para o Presidente da República. A reordenação do pacto político seguia os fios de uma rede de interesses que escapava às antigas praticas republicanas. Os Estados, pequenas pátrias, perderam, então, a capacidade de dirigir a República. O golpe de 1937 fez-se em silêncio, apesar dos fartos indícios de sua ocorrência. As vozes da imprensa e das oposições se acomodaram em um murmúrio conveniente. Apenas o candidato Armando de Salles Oliveira encaminhou o manifesto Aos chefes militares do Brasil, apressando, ao contrário do que pretendia, o golpe. A imprensa ajustou-se às novas regras, e os representantes da ordem liberal seguiram o caminho do exílio (2012, p. 173).

A instalação da ditadura foi possível, portanto, ao contar com sólido apoio dos militares e de quase todos os governadores, até mesmo do governador paulista, Cardoso de Mello Neto. Segundo Sandes:

Vitorioso, o governo fundou um novo regime de historicidade. $O$ Estado Novo formulou uma percepção do passado em que o folclore indicava uma tradição de longa duração a ser preservada, enquanto a história, assentada na trama dos acontecimentos, se deslocava para um passado distante, em busca dos processos definidores da nação (GOMES, 1996). A experiência política que demarcou a moldura constitucional como projeto político nacional transformou-se, em pouco mais de três anos, num passado distante: experiência negativa, que se devia esconjurar e esquecer. (2012, p. 175).

Nossa leitura das fontes foi presidida pela preocupação em conhecer o pensamento do grupo armandista, expresso nas ideias de seu líder principal, Armando de Salles Oliveira. Interessou-nos também conhecer as ideias de um político de seu grupo, Paulo Duarte, quadro atuante nas ações anti-varguistas, integrante ativo do Partido Constitucionalista. No capítulo seguinte, enfocaremos a análise no pensamento e ação de Paulo Duarte, que se intitulava como amigo pessoal, como integrante do seleto grupo de armandistas, que circulava na órbita de Salles Oliveira e sua atuação política. É fonte que alimentou nosso esforço em 
escrever a história dessa experiência singular e pouco tratada pela historiografia do período. 


\title{
CAPÍTULO III: PAULO DUARTE, MEMÓRIA, HISTÓRIA E RESSENTIMENTO
}

\author{
Quando se escrever a história desse momento qual será o \\ julgamento de tanta sem-vergonhice? (DUARTE, 1977, p. 66)
}

\subsection{Memória e arquivo}

Paulo Alfeu Junqueira de Monteiro Duarte (1899-1984), o Paulo Duarte, iniciou a escrita de seu projeto memorialístico na segunda metade da década de 1960. Intitulado como Memórias. O trabalho resultou em nove volumes, cerca de três mil páginas acerca de sua vida pessoal e política, publicados entre 1974 e 1979. A empreitada memorialística teve o auxilio de um arquivo político, cuidadosamente reunido, guardado e organizado pelo próprio memorialista ao longo de sua vida. $\mathrm{O}$ termo "arquivo político" foi usado pelo próprio Paulo Duarte já no prefácio de seu primeiro volume de memórias. Entendemos que o arquivo de Paulo Duarte é político não apenas porque reúne documentos pessoais, mas também de outros membros de seu grupo político, documentos públicos e, sobretudo, porque são registros políticos. Além disso, ele constrói uma memória e se posiciona politicamente sobre os acontecimentos que vivenciou e testemunhou.

Paulo Duarte foi idealizador de projetos no campo cultural e político de São Paulo. De acordo com a historiadora Marli Hayashi, assim como Dom Quixote, Paulo Duarte passou sua vida brincando de sonhar sonhos impossíveis, dentre eles estavam o Departamento de Cultura, o Instituto de Criminologia, o Museu do Homem Americano, a Revista Anhembi e o Instituto de Pré-História. Alguns desses sonhos ficaram apenas no plano da aspiração, outros chegaram a ser executados, mas foram frustrados ou bruscamente interrompidos ${ }^{67}$. Entretanto, é através da

\footnotetext{
${ }^{67}$ Interessa-nos pensar a trajetória de Paulo Duarte a partir de seu envolvimento com o grupo político do jornal O Estado de S. Paulo, que identificamos anteriormente como grupo armandista, ou seja, ligados ao projeto de eleger Armando de Salles Oliveira para presidente do Brasil. Para mais informações sobre a trajetória profissional e pessoal do memorialista, anterior e posterior ao recorte escolhido, e sobre outros projetos por ele elaborados, consultar os seguintes trabalhos: FUNARI, Pedro Paulo. Paulo Duarte e o Instituto de PréHistória, Idéias, Campinas, v. 1, p. 155-179, 1994. ZIOLI, Marcos. Paulo Duarte (1899-1984). Um intelectual nas
} 
idealização desses projetos, que Paulo Duarte teceu uma impressionante rede de sociabilidade com intelectuais e políticos de sua época. Graças ao vinculo com a comunidade política do jornal O Estado de S. Paulo, Paulo Duarte participou de episódios da vida política e cultural paulista. Essa ligação pode ser considerada uma expressão de uma sociabilidade que Jean-François Sirinelli chamou de "sensibilidade ideológica ou cultural comum" em torno da qual um grupo de intelectuais ou políticos se organiza, partilhando dos mesmos projetos. "Todo grupo de intelectuais organiza-se também em torno de uma sensibilidade ideológica ou cultural comum e de afinidades mais difusas, mas igualmente determinantes, que fundam uma vontade e um gosto de conviver; São estruturas de sociabilidade difíceis de apreender, mas que o historiador não pode subestimar" (SIRINELLI, 2003, p. 257).

No prólogo do primeiro volume de suas memórias, Raízes Profundas (1974), Duarte escreveu as "Razões de defesa por ter vivido", justificando a necessidade de relatar determinados episódios por ele vivenciados pelo memorialista. Para o memorialista, apenas uma vida de ações, coerente com o posicionamento político daquele que resolve escrever suas memórias, era digna de ser contada. A sua, sem falsa modéstia, deveria ser objeto de uma escrita memorialística:

Muita gente não precisava nem de escrever memórias. São amnésicos ou, melhor, deviam ser amnésicos, mas isso no sentido de possuir e não no de ter perdido o próprio passado. Porque não têm o que contar ou nem o devem contar. Vida confidencial ou insípida, medíocre, vegetativa ou inconfessável, ou nem nada de interessante a não ser maldades ou manhas, complementos ou atributos da alma humana. Outros não as escrevem para não lembrar coisas que, no próprio interesse, devem mesmo ser conservadas em silêncio. O passado faz medo ou desagrada a muitos (DUARTE, 1974, p. 1).

Jornalista, político, combatente, organizador, cientista, escritor, assim Antônio Candido (CANDIDO, 1979) definiu Paulo Duarte, indicando, nessa definição, que certamente o memorialista não se encaixava no perfil daqueles que "não possuem nada para contar". Algo que chama a atenção na narrativa do memorialista é justamente sua escolha em não omitir as frustrações e derrotas sofridas, esse "passado que faz medo e desagrada a muitos". Por outro lado, também é possível

trincheiras da memória. Tese de doutorado, Unesp, 2010; HAYASHI, Marli Guimarães. Paulo Duarte. Um Quixote brasileiro. Editora Hucitec. São Paulo, 2010. 
apreender de sua narrativa que a culpa por tais insucessos vividos é sempre atribuída ao "outro, no caso, aos seus inimigos políticos, que agiram movidos pelo desejo de poder ou em prol de interesses próprios; ou até mesmo é creditado aos amigos, que não se engajaram devidamente em seu projeto de luta política. Nesse sentido, Paulo Duarte reconhecia-se como credenciado portador da verdade a respeito de seu passado político e, como tal, defendia que narra-lo ajudaria a esclarecer dúvidas, explicitar divergências: "a jurisprudência da verdade que me ficou, dá-me, porém, toda autoridade para falar do meu passado, fala que não é propriamente memórias, melhor diria "razões de defesa por ter vivido" (1974, p. 5).

A segurança em se autoproclamar portador autorizado da verdade acerca dos acontecimentos políticos de sua época e de sua própria atuação política sustenta-se no expressivo e volumoso aporte documental que conseguiu organizar e preservar:

Ora, razões de defesa mais valor têm quando acompanhadas de documentos e provas incontestáveis no maior número possível. Possuo um arquivo de mais de cem mil comprovantes, embora mutilado pelas invasões repetidas mais de uma vez do meu domicílio pela polícia e ainda de papeis desaparecidos pela vida nômade que me condenaram cerca de dez anos de exilio e alguns anos mais de prisões, somadas todas as que cumpri umas às outras, isso sem contar fugas e coutos quando acossados pelos beleguins da política e das revoluções. Assim mesmo, os milhares que me ficaram escapados dessas invasões e sobressaltos são suficientes para validar qualquer prova civil, criminal ou histórica (DUARTE, 1974, p. 5).

O zelo em guardar cartas, documentos, diários, resultou na montagem de um extenso arquivo político com cerca de vinte e duas pastas com milhares de documentos, divididos em vida pessoal, política, produção intelectual, cartas, recortes de jornais, entre outros. O memorialista também organizou dossiês políticos sobre Armando de Salles Oliveira, a campanha eleitoral de $1937^{68}$, o Partido Constitucionalista $^{69}$ e sobre Ademar de Barros $^{70}$. Paulo Duarte menciona ainda a

\footnotetext{
${ }^{68} \mathrm{O}$ dossiê a respeito de Armando de Salles Oliveira e sua vida política é composto por cartas trocadas entre o político e alguns membros do grupo armandista e políticos aliados, sobretudo com Vivaldo Coaracy, Arnon de Mello, Otávio Mangabeira, entre outros. Contém ainda artigos jornalísticos e documentos referentes à organização da campanha presidencial de 1937.

${ }^{69}$ O dossiê sobre o Partido Constitucionalista está composto principalmente de recortes de jornais publicados durante a atuação do partido, entre fevereiro de 1934, data de sua fundação, e novembro de 1937, data de sua extinção devido ao golpe do Estado Novo.

${ }^{70}$ Membro do PRP, Ademar de Barros foi inimigo histórico de Paulo Duarte, daí a importância de constituir um
} 
constituição de uma biblioteca pessoal, já nos anos 1930 composta por milhares de títulos. Embora se reconhecesse apenas como um curioso e pesquisador da história do Brasil, não escondia o orgulho de que sua farta biblioteca tenha servido de apoio até mesmo para que Armando de Salles Oliveira pudesse preparar seus discursos de campanha política. Ao se reconhecer como um homem letrado, um erudito, e registrar que até mesmo Salles Oliveira fazia uso de sua biblioteca para pensar e escrever seus discursos, escritos indispensáveis à divulgação do pensamento armandista e do projeto político do grupo, Paulo Duarte se identifica como alguém indispensável ao político e seu grupo. É importante assinalar aqui que há a postulação de uma "grandeza" no modo como Paulo Duarte se reconhecia.

Em 1970, como Paulo Duarte se encontrava mais uma vez com sérias dificuldades financeiras, negociou a venda de sua biblioteca para a Unicamp. Durante a negociação, ficou acordado que, como reconhecimento do interesse da Unicamp por sua biblioteca, o memorialista doaria seu arquivo pessoal para a universidade. Após sua morte, o arquivo seguiu primeiro para o Siarq (Arquivo Central do Sistema de Arquivos) e, posteriormente, em agosto de 1994, para o Centro de Documentação Alexandre Eulálio, onde se encontra atualmente. Uma visão de seu legado documental tornou-se possível a partir da aquisição de seu arquivo pelo CEDAE. Posteriormente foi constituído o Fundo Paulo Duarte. ${ }^{71} \mathrm{~A}$ venda da biblioteca, seu maior e também único patrimônio, foi relatada com pesar pelo memorialista:

Dois motivos únicos me levaram a dispor dessa biblioteca: o desejo ardente de não vê-la dispersada em caso de minha morte e uma razão de premência e necessidade: as misérias deste nosso Brasil e a minha própria miséria (parafraseando Maurice Sele) que me obrigam a procurar recursos para uma vida de apreensões materiais

arquivo a respeito do político perrepista. Durante a guerra civil de 1932, chegaram a lutar juntos pela reconstitucionalização do país. Entretanto, quando o grupo armandista ascendeu ao poder, a partir de 1933, Ademar de Barros fez ferrenha oposição à administração armandista. Afirmou que Armando de Salles Oliveira estava utilizando a estrutura governamental para fazer sua campanha à Presidência. Acusou-o ainda de criar cargos bem remunerados para beneficiar correligionários e aliados, além de demonstrarem solidariedade ao governo Vargas. (HAYASHI, 2005). Em contrapartida, de acordo com Luiza Cotta (2008), ninguém influenciou negativamente a carreira política de Ademar de Barros tanto quanto Paulo Duarte. Paulo Duarte usou o jornal O Estado de S. Paulo e a Revista Anhembi para articular intensa campanha onde acusava o político perrepista de corrupção e enriquecimento ilícito, durante o governo em São Paulo. Seria, segundo a autora, o autor do histórico mote atribuído à gestão de Ademar de Barros à frente do governo de São Paulo: "rouba, mas faz".

${ }^{71} \mathrm{O}$ arquivo de Paulo Duarte encontra-se disponível para pesquisa. As informações a respeito da trajetória do arquivo foram coletadas quando da nossa visita ao CEDAE, em 2015, que se encontra no IEL (Instituto de Letras e Linguagem da Unicamp). 
que se torna cada dia mais difícil e insuportável, que só poderia ser amenizada com a venda desse praticamente único patrimônio que possuo (DUARTE, 1974, p. 3).

Em seu arquivo encontramos documentos diversos, dentre estes, as correspondências trocadas entre Armando de Salles Oliveira e aliados políticos da época ${ }^{72}$, principalmente cartas a respeito de sua campanha à sucessão presidencial. A narrativa memorialística de Paulo Duarte é frequentemente interrompida pela apresentação dessas cartas, para que possa melhor esclarecer e, o mais importante, comprovar o que está sendo narrado. O uso dessas correspondências é seu suporte documental, balizando a organização de uma memória. Nesse sentido, Paulo Duarte defendia que, ao contrário do tradicionalmente praticado,

A verdadeira história não é contada pelos documentos oficiais, mas pela correspondência e os diários deixados por grandes figuras, testemunhas exatas de acontecimentos ou nomes notáveis na política e na literatura, como Saint Simon, por exemplo, cujos quase duzentos cadernos de memórias levantavam a época neles contidas (DUARTE, 1974, p. 2).

Sob tal perspectiva, e mobilizado pela proposta de escrever a "verdadeira" história de sua época e de sua vida, que parecem a ele indissociadas, as correspondências de seu arquivo pessoal representam a principal fonte, exaustivamente apresentada, dos seus nove tomos de memórias. A respeito do uso da correspondência como suporte empírico para a escrita da história, Ângela de Castro Gomes comenta a função desse aporte na apreensão do passado: a de representar as experiências vivenciadas e narradas pelos agentes históricos. Para a historiadora,

fica evidente a função da correspondência como um importante espaço de sociabilidade tanto para personagens ilustres da história nacional, quanto para pessoas "comuns", pois, através dela, tais indivíduos expressaram e construíram seus afetos, seus projetos e suas trajetórias (2009, p. 7-8).

Paulo Duarte, não como especialista, mas como ele mesmo se reconhecia, como meticuloso "curioso" da história do país, guardava cópias e originais das

\footnotetext{
72 No arquivo, as cartas estão dividas entre "correspondências enviadas", "correspondências recebidas" e "correspondências de terceiros". Armando de Salles Oliveira correspondeu-se principalmente com Vicente Ráo, Vivaldo Coaracy, Antônio Mendonça, Arnon de Mello, membros de seu grupo político e fundamentais no desenvolvimento da campanha eleitoral de 1937.
} 
correspondências escritas e enviadas por ele, destinadas a ele e também de membros próximos a ele, as quais teve acesso. Seu zelo em arquivar todo documento que dizia respeito, direta ou indiretamente à sua pessoa, traduziu-se inclusive na aquisição do arquivo pessoal de Armando de Salles Oliveira. Após a morte do ex-governador, seu arquivo pessoal acabou indo parar nas mãos de Paulo Duarte sendo incorporado ao seu arquivo político. Dessa forma, foi possível verificar o comprovado uso das correspondências recebidas por Armando de Salles Oliveira na narrativa memorialística de Paulo Duarte, como era o intuito deste. O uso da correspondência pessoal, bem como de um conjunto de cartas de membros do grupo armandista, revela-nos os objetivos e o modo como Paulo Duarte construiu e organizou suas memórias, integradas à de seu grupo político e intelectual. Há a visível preocupação em conferir visibilidade à sua atuação política nos complexos acontecimentos dos anos 1930-1945. Por que Paulo Duarte documentou suas experiências pessoais e políticas, constituindo um acervo de tamanho considerável e que tem servido para alimentar pesquisas e fundamentar estudos a respeito da história política de São Paulo e do Brasil? Em nosso caso, esse acervo fundamentou parte de nossa pesquisa e das reflexões dela decorrentes acerca da atuação política do grupo armandista, do qual Paulo Duarte foi integrante aguerrido e sobretudo um "guardião" da memória de tal atuação, que ele reputa como a "verdade" acerca das experiências vividas naquele período turbulento de nossa hsitória. No projeto memorialístico de Paulo Duarte, história e memória trabalham juntas, revelando-se como um esforço de construção de um lugar de memória. O arquivo não teve apenas a função de armazenar organizadamente a documentação cuidadosamente recolhida, reunida e guardada por Paulo Duarte ao longo de sua vida. Mais que isso, o arquivo conta sua história. O passado relatado em suas memórias/arquivo poderia ser "recuperado" tal como ocorre e devidamente comprovado pelas fontes ali organizadas. Arquivo, memória e história se confundem, se entrelaçam, se imbricam nesse exercício de preservação de um acervo, de montagem de um cenário, de escrita da "verdadeira" história.

Todo esse procedimento remeto-nos às reflexões de Marcelo Moreschi ano analisar a construção feita por Mário de Andrade a respeito do movimento modernista. Por ocasião dos vinte anos da Semana de Arte Moderna, Mário de Andrade apresentou uma conferência, O Movimento Modernista, no qual, 
similarmente a Paulo Duarte, também se reconheceu como "historiador autorizado" daquela experiência, na qual foi um dos protagonistas e também testemunha. Nas palavras de Moreschi:

De antemão, é preciso assinalar que as duas dinâmicas atendem, no texto de Mário, a duas exigências persuasivas que devem ser levadas em conta para uma leitura não caudatária da conferência. Em primeiro lugar, elas se relacionam ao esforço da constituição da figura de Mário como historiador autorizado do "movimento" que seu texto retrospectivamente instaura - tal constituição é realizada de modo que sua posição simultânea de agente da história e de seu fixador não pareça suspeita ou comprometedora. Em segundo lugar, o uso das duas dinâmicas é realizado também numa tentativa de articulação de uma versão da história que se pretende não perecível (MORESCHI, 2013, p. 3).

Mencionamos o trabalho de Moreschi a respeito de Mário de Andrade como "historiador de si" porque parece ser esse o caso de Paulo Duarte ao construir um arquivo, montar suas memórias e relatar sua história. Com efeito, ao afirmar que irá relatar a "verdadeira" história, assegurada por um arquivo político, Paulo Duarte também se coloca na função de agente da história, o arquivo serviria justamente à prova documental e cabal que afastaria qualquer suspeita sobre o relatado. Nesse sentido, as memórias poderiam ser tomadas como sinônimas da história, já que há "provas" de que ocorreram tal como o relatado por Duarte. Tal como Mário de Andrade, Paulo Duarte se coloca também na posição de "historiador autorizado" dos movimentos políticos de sua época.

Moreschi (2012) faz referência a uma prática de autodocumentação e automonumentalização, que também pode ser identificada no caso de Paulo Duarte. Ela pode ser reconhecida na documentação exaustiva que Duarte faz de sua trajetória bem como de seu grupo político. Nesse esforço e afã de se constituir como "historiador autorizado". Nesse sentido, a vontade de Duarte é a de que os documentos ele deixados não sejam tratados apenas resíduos históricos, peças de uma história maior, mas já são exatamente a história que deve ser reproduzida por quem futuramente acessasse o arquivo e suas memórias.

Ao pensar a constituição e função dos arquivos, a historiadora Antonella Salomoni defende que: "os arquivos não são uma acumulação indistinta e plural de documentos, mas sim, desde sua constituição, o resultado de um projeto de fazer a história". Quando defendemos que arquivo e memória trabalham juntos na escrita de 
uma história, no caso de Paulo Duarte, compartilhamos a posição da autora de que: "o arquivo deve colocar-se a serviço da memória, que abriga, em si mesma, uma função política" (SALOMONI, 2011, p. 45). Ao redigir suas memórias, buscar comprová-las mediante a constituição de um arquivo político, Paulo Duarte tem um "projeto de fazer a história". Como Salomoni ressalta, ele colocou o arquivo a serviço da memória, permitindo que o futuro leitor/historiador pudesse aferir memória e arquivo, conferindo razão ao memorialista; autorizando, portanto, seu discurso. A redação das memórias respaldada em um suporte material, o arquivo político, foi, sem dúvida, a maneira que Paulo Duarte encontrou de deixar narrada a "verdade" acerca de sua história, controlando, supostamente, as narrativas posteriores à sua. Ao se apropriar de sua própria história ele busca influenciar diretamente a história que seria escrita a respeito de uma experiência histórica ocorrida em período de grande efervescência política da história do Brasil (1930-1945), na qual o memorialista reconhece ter atuado ativamente.

Marlon Salomon organizou obra a respeito do saber dos arquivos. Segundo o historiador, há um saber próprio aos arquivos, que portam traços de um saber do passado, com os quais o historiador pode e deve fazer alguma coisa. Os arquivos tornam possível aos historiadores, "de certa forma, apropriar-se da memória do ausente e impedir que ele se transforme em pesadelo ou fantasma" (2011, p. 8). Apropriar-se aqui está no sentido de ter acesso às memórias do ausente, fazendo com que elas venham a público. Em diálogo com Arlette Farge, Salomon sublinha a importância do arquivo como "dispositivo fundamental da história", ao afirmar que:

Justamente porque os arquivos não são espaços da preservação e da conservação - muito embora as reflexões dos historiadores a seu respeito se restrinjam a isso que poderíamos chamar de aspecto orgânico dos arquivos. Os arquivos não devem ser pensados como organismo, organização: este é o bom senso taxinômico do bibliotecário. $\mathrm{O}$ arquivo é a dobra que deve ser desdobrada no fluxo do pensamento pelo historiador. Como se, escreve Farge, "desdobrando o arquivo pudéssemos tocar o real". E o historiador não pode deixar para o bibliotecário o que deveria pensar. $\mathrm{O}$ arquivo é, antes de tudo, o dispositivo fundamental da história (SALOMON, 2011, p. 14).

De fato, ao pensar os arquivos apenas como um espaço de preservação, o historiador perde a dimensão de que o próprio arquivo carrega uma história, 
sobretudo no que diz respeito aos arquivos privados, como no caso de Paulo Duarte. Se, como defende Certau, na escrita da história "tudo começa com o gesto primeiro de por à parte, de reunir, de transformar em "documentos" certos objetos distribuídos de outro modo" (CERTAU, 1982, p. 73), tal operação teria início antes mesmo da ida do historiador ao arquivo, ela começa no momento de sua constituição. Os documentos que fazem parte do acervo de um arquivo carregam a função de documento/monumento, tal como pensado por Jacques Le Goff:

O documento não é qualquer coisa que fica por conta do passado, é um produto da sociedade que o fabricou segundo as relações de forças que aí detinham o poder. Só a análise do documento enquanto monumento permite à memória coletiva recuperá-lo e ao historiador usá-lo cientificamente, isto é, com pleno conhecimento de causa (LE GOFF, 1990, p. 471).

Daí a importância do historiador fazer "a crítica do documento - qualquer que ele seja - enquanto monumento." Inclusive a análise crítica de seu abrigo em determinado arquivo. A mesma crítica deve ser estendida às memórias enquanto documento. Quando defendemos que o arquivo está a serviço da memória, estamos pensando com Paul Ricœur, em sua reflexão a respeito do papel da memória para escrita da história. Diante da tradição histórica da valorização do arquivo e de seus documentos - haja vista a insistência de Paulo Duarte ao ressaltar que suas memórias tinham maior veracidade e credibilidade, pois encontram-se ancoradas em organizado arquivo - a memória teria função secundária de apenas alimentar a história, já o arquivo teria papel primordial, de guardião do passado, que preserva e revela suas verdades. Paul Ricœur alerta-nos que, nessa relação, memória, arquivo, história,

Será preciso, contudo, não esquecer que tudo tem início não nos arquivos, mas com o testemunho, e que, apesar da carência principal de confiabilidade do testemunho, não temos nada melhor que o testemunho, em última análise, para assegurar-nos de que algo aconteceu, a que alguém atesta ter assistido pessoalmente, e que o principal, se não às vezes o único recurso, além de outros tipos de documentação, continua a ser o confronto entre testemunhos (RICOEUR, 2007, p. 156).

No arquivo organizado por Paulo Duarte evidencia-se seu papel de testemunha. Suas memórias são uma via de acesso ao seu passado, podendo ser conferidas através do arquivo deixado, espécie de garantia inquestionável quanto à 
verdade e confiabilidade de suas memórias. De acordo com Paul Ricœur, antes do arquivo constituído a ponto de ser consultado, há o arquivamento. $\mathrm{O}$ arquivo não seria apenas um lugar físico, mas também um lugar social.

Aqui a ênfase será dada aos traços por meio dos quais o arquivo promove a ruptura com o ouvi-dizer do testemunho oral. Assume o primeiro plano a iniciativa de uma pessoa física ou jurídica que visa a preservar os próprios rastros de sua própria atividade; essa iniciativa inaugura o ato de fazer história (RICOUER, 2007, p. 178).

Nesse sentido, arquivo e memória devem ser devidamente problematizados e criticados. Enquanto o arquivo era considerado o lugar seguro para acessar as experiências vivenciadas do passado, a memória esteve submetida à desconfiança do historiador, pois a ela era atribuído caráter subjetivo, pecado capital da história de matriz positivista. Contemporaneamente, Sabina Loriga (2009) aponta que, a partir dos anos 1950/60, houve uma espécie de revolta dos historiadores com a chamada "história oficial" ${ }^{73}$, que passou a ser acusada de arbitrária. A partir de então, o estudo da memória tornou-se um campo de reflexão e de problematização, caro também aos do ofício. Paul Ricœur, em A memória, a história e o esquecimento, nos convida a ter um olhar mais positivo para a problemática relação entre memória e história. De acordo com o filósofo,

\begin{abstract}
apesar das armadilhas que o imaginário arma para a memória, podese afirmar que uma busca específica da verdade está implícita no olhar sobre a coisa passada [...] Essa busca da verdade específica a memória como grandeza cognitiva. Mais precisamente, é no momento do reconhecimento, no qual se conclui o esforço da lembrança, que essa busca da verdade se declara. Sentimos e sabemos então que algo se passou, que algo aconteceu, que nos implicou como agentes, como pacientes, como testemunhas. (RICOEUR, apud LORIGA, 2009, p. 19).
\end{abstract}

Ao propor um olhar mais atento para memória, sobretudo propondo para as "armadilhas que o imaginário arma para a memória", Ricœur está instigando-nos a investir em um novo olhar sobre o papel que o memorialista ocupa na escrita da história (ZIOLI, 2012) O memorialista, bem como suas memórias, não seriam apenas auxiliares do historiador, complementos, mas um elo entre o historiador que está no presente e o passado sobre o qual se quer escrever. São orientações que nortearam

\footnotetext{
${ }^{73}$ A história oficial que a autora está criticando é a história dos grandes personagens, dos grandes lideres políticos, a partir da qual a história dos acontecimentos era ditada.
} 
nossa leitura da documentação do arquivo de Paulo Duarte, pois procuramos exercitar não apenas um olhar positivo, mas sobretudo um olhar crítico, tanto para os documentos cuidadosamente reunidos e arquivados por Paulo Duarte quanto para suas memórias. Não desconsideramos que Paulo Duarte construiu suas memórias de acordo com sua subjetividade. Identificar as subjetividades na construção da memória é uma das tarefas do historiador profissional. Enquanto memorialista, Paulo Duarte confessa que vai contar a verdade, para tanto, evoca o auxílio do arquivo. Cabe ao historiador, por sua vez, o compromisso de questionamento da verdade ofertada por memória e arquivo,

No entanto, a essa dimensão relacionada a uma interrogação interna dos arquivos somaram-se outras preocupações decisivas, como aquelas sobre a própria produção dos arquivos, pois, como mostra Arlette Farge, inspirada em Michel Foucault, se "o arquivo não diz a verdade", certamente "ele diz da verdade", quer dizer, das forças indissociáveis de suas condições de produção e de atualização historiográfica. Pois toda atualização historiográfica pode seguir uma ordem corrente dos arquivos, pode coloca-la em questão ou pode desordena-la (quer dizer, reinventá-la). Toda atualização historiográfica parte de um ou opera um recorte nos arquivos: constitui um quadro de relações entre conjuntos quaisquer de materiais documentais/monumentais (SALOMON, 2012, p. 15-16).

Cientes dos embates e disputas entre memória e história, e também de suas relações e intercessões, não buscamos verificar a "verdade" dos relatos de Paulo Duarte. Mas, procuramos justamente apreender o uso que ele faz do discurso da memória para lembrar, precisar e legitimar sua história acerca de sua atuação e localização na política. Interessa-nos assim apreender seu modo de ver a experiência política sua e do grupo político do qual fazia parte, que incluiu conhecer as suas condições de produção, sinalizadas na cultura política da década de 1930, nos jogos de poder, nas linguagens compartilhadas, nas estratégias de luta e de atuação, nos significados conferidos às experiências vivenciadas e às narrativas produzidas sobre elas. pois disposta em imenso arquivo e expressa em cerca de três mil páginas. O prólogo Razões de defesa por ter vivido, que abre os nove tomos de memórias de Paulo Duarte é bastante revelador dos propósitos do autor. Como avalia Beatriz Sarlo, "o discurso da memória transformado em testemunho tem a ambição da autodefesa: quer persuadir o interlocutor presente e assegurar-se uma posição no futuro" (SARLO, 2005, p. 51). Parece-nos ser justamente esse o caso de Paulo Duarte no que diz respeito às suas memórias sobre sua atuação política junto 
ao seu grupo: tem a "ambição da autodefesa" e também de persuadir o interlocutor presente, de assegurar-se um lugar na história. Com efeito, apesar de ter dado início à escrita e publicação de suas memórias somente em 1974, seu arquivo político começou a ser constituído já nos anos 1930, principalmente durante os dois exílios enfrentados. Entretanto, o arquivo tornou-se de acesso ao público também na década de 1970, com a venda para o CEDAE.

A partir das reflexões consideradas, entendemos que a constituição de um arquivo e de uma produção memorialística ancorada naquele suporte, indicam-nos que, havia, da parte de Paulo Duarte, o desejo de ser lembrado, de ter um lugar assegurado na história do período de 1930-1945, e até mesmo a ambição de autodefesa na avaliação que faz de sua atuação nos acontecimentos políticos do período. Nesse sentido, reunir e guardar a correspondência privada, artigos escritos em periódicos a respeito da atuação de um grupo em determinado período, discursos políticos, dossiês temáticos organizados, entre outros, constituem "um tipo de documento que combina exercícios de produção do "eu" e de persuasão política dos outros (e de si mesmo)" (GOMES, 2009, p. 42).

Portanto, a partir da leitura das memórias produzidas por Paulo Duarte e das consultas aos documentos do arquivo do memorialista, procuramos localizar seu desejo de persuadir o leitor e também a si mesmo, acerca sua de sua atuação política durante o governo de Getúlio Vargas (1930-1945) em dois pontos: primeiro, o que afirma sua uma trajetória profissional e pessoal como importante para a história do período e para e desenvolvimento do país; segundo, o que afirma sua coerência política e fidelidade de revolucionário, pois lutou ativa e incansavelmente contra Getúlio Vargas e, se não obteve sucesso, foi unicamente em razão da incapacidade de outros membros de seu grupo, pois não se comportaram como verdadeiros revolucionários. No primeiro ponto, novamente identificamos sua vontade de assegurar seu lugar na história, ao ressaltar "grandeza" em seu papel político e social. No que diz respeito ao segundo ponto, a da "ambição de autodefesa". Nos dois, o ponto comum de conexão, o viés antivarguista, sem concessões.

A memória de luta contra o ditador percorrerá a escrita do memorialista ao longo dos nove tomos e expressará o sentimento de ressentimento também em relação aos outros membros do grupo armandista. O ressentimento, uma expressaõ 
dessa autodefesa, aparece nas memórias de Paulo Duarte tanto no período que antecede o golpe de novembro de 1937, quanto no período posterior a ele. Paulo Duarte, ao fazer auto avaliação de sua participação nos projetos do grupo, se considera como parte importante dele, como peça importante de todo o esquema de luta contra o varguismo. Avalia, também, a atuação de outros membros, considerando-os equivocados em algumas de suas ações. No caso de Armando de Salles Oliveira, o sentimento é ambíguo, ora enaltecendo o político e amigo, ora responsabilizando-o pelos fracassos do grupo.

Ao ressaltarmos o viés antivarguista presente nas memórias e arquivos de Paulo Duarte, pareceu-nos ser essa a vontade dele em desvincular as ações do grupo político armandista do governo Varga, em demarcar a posição política do grupo. É preciso lembrar, porém, que Paulo Duarte, embora afirme ter sido contra qualquer aproximação do grupo com Vargas, acabou cedendo e apoiando Armando de Salles Oliveira em sua decisão de compor com o governo central, exercendo, inclusive, cargos na administração pública nesse momento. Paulo Duarte tinha Salles Oliveira como uma liderança e, apesar de nem sempre estarem de acordo, as decisões de Salles Oliveira eram respeitadas. Nesse sentido, é visível sua autodefesa quanto ao apoio a Salles Oliveira quando este se aproximou de Getúlio Vargas. Fazendo posteriormente a autocritica e critica do grupo, e conhecendo o desfecho da história do grupo político paulista, ele procurou justificar tal aproximação e também fazer a crítica aos posicionamentos tomados por Salles Oliveira, cruciais para o desfecho do jogo político, com a derrota do grupo e efetivação do golpe de 1937.

\subsection{O golpe de novembro de 1937 nas memórias de Paulo Duarte}

A campanha política para eleger Armando de Salles Oliveira presidente do Brasil estava intensificada quando o grupo armandista foi surpreendido com a notícia dos planos de Getúlio Vargas para novembro de 1937. Diante disso, decidiram não mais recuar e fizeram oposição explicita aos planos de Vargas, aprovando uma carta redigida por Armando de Salles Oliveira que denunciava a possibilidade de um golpe de Estado. Ao fazer isso, o grupo armandista rompia o silêncio político até então 
praticado em relação aos desmandos do governo Vargas No entanto, era tarde para agir e resistir, já que o golpe pegou-os de "surpresa" e sem consolidar as alianças ensaiadas e anunciadas, analisadas no capítulo anterior. O grupo descobriu que se encontrava isolado nesse pesado jogo contra o governo Vargas, sem o necessário apoio político e militar. Apesar de Paulo Duarte afirmar que o golpe pegou-os de "surpresa", como assinalamos anteriormente, o próprio jornal O ESP, desde setembro de 1937, publicou artigos insinuando um possível golpe continuísta por parte do governo Vargas. Pode-se pensar que o grupo armandista usou como estratégia para combater um possível golpe a intensificação da campanha eleitoral. Entretanto, o crescente apoio à candidatura Salles Oliveira e da campanha eleitoral não foram suficientes para assegurar que a sucessão presidencial ocorresse democraticamente; pelo contrário, acelerou os planos continuístas de Vargas que, ao sentir-se ameaçado, contra-atacou, articulando o golpe de Estado.

Ao escrever Ofício das trevas, seu sexto volume de memórias, publicado em 1977, Paulo Duarte, contemporâneo dos desfechos do golpe de 1937, relembra a campanha eleitoral de Armando de Salles Oliveira, deflagrada em concomitância à ação dos militares e do governo varguista, direcionada para o golpe. Segundo seu relato, a movimentação do Exército foi decisiva para a deflagração do golpe e não a antecipação da sucessão presidencial:

Sempre os militares inquietando a nação num momento em que se dava a prova mais segura de que nada perturbava a calma do País, que apenas manifestava seu entusiasmo pelas próximas eleições. [...] Chego a pensar se, antes de meter o ombro a qualquer importante problema nacional, como quer Armando de Salles Oliveira, se devia, primeiro, reeducar e disciplinar o Exército. Mas quem será capaz de pôr o guizo no pescoço do gato? (DUARTE, 1977, p. 1).

Para Paulo Duarte, ainda que muitos políticos soubessem sobre o que estava prestes a acontecer quanto aos rumos políticos do país, os mesmos estavam presos "aos nós apertados com que Getúlio Vargas sabia manietar os seus asseclas" (1977, p. 2), inclusive os militares, que também estariam servindo aos interesses do chefe do governo federal. Claro que a avaliação de Duarte do papel dos militares é simplista, colocando-os, a princípio, apenas como marionetes de Vargas. No entanto, sabemos que a participação dos militares, através de Góes 
Monteiro e o General Dutra, foi fundamental para a elaboração e deflagração do golpe de novembro de 1937. Vargas também serviu ao interesse dos militares.

Dos "asseclas", Paulo Duarte excluía Armando de Salles Oliveira, visto por ele como um "estadista" e não um político submisso com quem compartilhava um projeto político de dominação nacional. Armando de Salles Oliveira era por ele considerado um político de visão, que sabia dar "passos largos", pragmático, atributos, esses, que explicariam, convenientemente, sua composição com Vargas. Seria apenas uma tática do jogo, um caminho para alcançar o pretendido, no caso, a sucessão presidencial. Já outros políticos seriam "desavergonhados", na avaliação de Paulo Duarte, haja vista o silêncio da Câmara diante da mensagem de "estado de guerra" encaminhada à ela por Vargas em 1937:

Assim, permaneceram eles firmes e indiferentes ao futuro e aos resíduos da própria dignidade que ainda lhes sobravam quando, ao amanhecer de 2 de outubro de 1937, antes de voltar o país da surpresa dos primeiros boatos, chega à Câmara dos deputados a mensagem de Getúlio solicitando o estado de guerra. (DUARTE, 1977, p. 2).

De acordo com Paulo Duarte, a justificativa para a declaração do estado de guerra veio com uma breve exposição dos motivos para sua decretação urgente, baseando-se não em fatos, "mas em frases patrioteiras e em afirmações outras dos ministros militares já citados: general Erico Gaspar Dutra e o Almirante Aristide Guilherme, aquele da Guerra e este da Marinha" (DUARTE, 1977, p. 17). Tratava-se, segundo o memorialista, de um documento forjado, elaborado por alguns integralistas do Exército. A mensagem solicitava a aprovação da Câmara à decretação do estado de exceção diante do perigo comunista, sem apresentar, porém, nenhuma prova.

Via-se que esses homens estavam todos conluiados e, assim, certos já do resultado. Mas lá se achava no recinto o deputado Otávio Mangabeira. "Se queremos resguardar o nosso decoro, que não é somente nosso, mas do País, não votemos sem exame de assunto desta natureza!" Mas estavam em maior número os deputados que haviam sido castrados durante aquela noite melancólica de 1 a 2 de outubro (DUARTE, 1977, p. 5).

$\mathrm{Na}$ ocasião, o deputado Valdemar Ferreira, presidente da Comissão de Justiça, subiu à tribuna para pedir 24 horas para emitir um parecer que esclareceria 
a constitucionalidade ou não do pedido de estado de guerra. Mas o plenário rejeitou o requerimento do líder paulista e aprovou o pedido do estado de guerra. A maioria votou a favor do parecer, sendo que apenas "quarenta e cinco deputados brasileiros defenderam a dignidade da Câmara Federal que se mutilava irremediavelmente", votando contra, como relata Duarte (1977, p. 6).

O estado de guerra foi decretado no início de outubro, pelo prazo de três meses, exatamente o período que faltava para a execução da eleição presidencial, evidenciando tratar-se de medida cuja pretensão era justamente a de cercear a propaganda política, como denunciaram os oposicionistas a Vargas. Segundo Duarte, o líder paulista na Câmara, Valdemar Ferreira, subiu novamente à tribuna alegando a inconstitucionalidade do pedido, que só podia ser admitido em caso de grave comoção interna, situação que não se verificava no Brasil naquele momento. O deputado também denunciou o Plano Cohen $^{74}$ e prosseguiu denunciando algo mais que estava para acontecer:

Há ainda um aspecto gravíssimo que é preciso repisar, diz Valdemar Ferreira. Até pelos corredores da Câmara certos arautos asseguram: não haverá eleições a 3 de janeiro; o mandato do presidente da República será prorrogado e o dos deputados também. Há um programa de subversão que está sendo friamente executado. "É preciso denunciá-lo ao País" - Valdemar alteia a voz - "e eu tomo sobre mim a responsabilidade de denunciá-lo!" - diz Valdemar Ferreira numa tempestade de aplausos. - "E o programa vai ser executado por etapas. Hoje é o estado de guerra. Se não o votarmos será a dissolução da Câmara. Mas dissolvida será ela de qualquer maneira. Os fatos confirmarão o que acabo de dizer e faço votos, os melhores votos, para que seja desmentido o que anuncio" (DUARTE, 1977, p. 6).

Segundo Duarte, aquele deputado defendia que o governo deveria prestar as devidas informações ao Poder Legislativo para que os deputados pudessem se posicionar acerca da situação enfrentada. Além disso, a Câmara também deveria ser informada dos termos da representação militar, só assim teria condições de votar, fundamentada e conscientemente, o estado de guerra. Todavia, a maioria dos deputados permaneceu em silêncio, "nesse diapasão, num ambiente de silêncio perplexo. O silêncio dos covardes" (DUARTE, 1977, p. 6). Para Duarte, o país havia

\footnotetext{
${ }^{74}$ De acordo com Paulo Duarte já era conhecido que o Plano Cohen não passava de "balelas anônimas que o Partido Integralista atribui aos comunistas e foram entregues às altas autoridades militares (não foram entregues; estas; as altas autoridades militares colaboraram na forgicação desses documentos, levada a cabo por um oficial integralista, o tenente Mourão)" (DUARTE, 1977, p. 6).
} 
sido apanhado de surpresa, não havia nenhum indício de comoção interna que de fato justificasse o pedido, daí a posição cautelosa e desconfiada daquele deputado da oposição. O que parecia seriamente ameaçado naquele momento era o regime que vigorava, possibilidade que foi contida com a declaração do estado de guerra por um período de três meses, ou seja, até a data marcada para as eleições. Mas o discurso de Valdemar Ferreira não encontrou ressonância junto à maioria da Câmara. Ou por interesses partidários, ou por acordos anteriormente firmados, ou pelo estado de subserviência do legislativo aos interesses do chefe do executivo. $O$ projeto de pedido de estado de guerra foi apoiado na sessão noturna, com o voto até mesmo da impensada Frente Única do Rio Grande do Sul, ${ }^{75}$ que neste momento já não mais se encontrava sob a liderança de Flores da Cunha.

Segundo Paulo Duarte, o jornal O Estado de S. Paulo foi o órgão de imprensa que se manteve firme em oposição à aprovação do projeto. Foi nele que Vivaldo Coaraci combateu sistematicamente o estado de guerra, com a mesma indignação de Valdemar Ferreira. Significativamente, em 2 de outubro de 1937, o periódico publicou em sua capa uma matéria sobre a votação, sob o seguinte título: "Com o voto contrário das bancadas de S. Paulo e do Rio Grande do Sul, a Câmara aprovou a decretação do estado de guerra" (OESP, 02/10/1937, p.1). Na matéria, o leitor é informado que o pedido de suspensão das garantias constitucionais e instituição do estado de guerra foi aprovado em regime de urgência, em duas sessões e que o líder constitucionalista, Valdemar Ferreira, foi quem fundamentou o voto contrário de sua bancada.

Como relembra Duarte, os ministros da Guerra e da Marinha, em exposição dirigida ao chefe do governo executivo, justificam o estado de guerra, já que, naquele momento, assim como em 1935, as ameaças do comunismo eram evidentes e que não era possível que todos ficassem inertes diante da catástrofe que se aproximava. Em seguida, Pedro Aleixo ${ }^{76}$, deputado mineiro e presidente da

\footnotetext{
75 União entre Partido Libertador (PL) e Partido Republicano Rio Grandense, do Rio Grande do Sul, para dar apoio à chapa de oposição formada por Getúlio Vargas, para concorrer às eleições em 1930.

${ }^{76}$ Pedro Aleixo foi um dos fundadores do Partido Progressista (PP) e deputado federal por aquele partido. Em maio de 1937, Pedro Aleixo foi eleito Presidente da Câmara Federal, tendo recebido 152 votos contra 131 dados a Antônio Carlos, representante das oposições. A derrota de Antônio Carlos foi considerada pela oposição à Vargas como um preparatório para instalação do golpe do Estado Novo. Pedro Aleixo foi considerado como um traidor. O jornalista Assis Chateaubriand teceu duras críticas a eleição de Aleixo, como assinalado anteriormente.
} 
Câmara, anunciou um requerimento de urgência para discussão e votação do projeto de lei, que constava de um único artigo, autorizando a decretação do estado de guerra equiparado à comoção intestina. Depois a votação passou pelo Senado.

Agora era a vez do Senado. No Senado aparece a primeira rachadura no bloco político de Armando de Salles Oliveira. A hora era mesmo dos fracos. O senador Alcântara Machado vota a favor da concessão do estado de guerra, enquanto o senador Paulo de Morais barros reacende o facho viril de Valdemar Ferreira. A hora era também dos homens verdadeiros. Dos "abaetês" do Brasil. [...] Anunciava-se a reforma da Constituição para permitir a reeleição do atual chefe de Estado. Proclamou-se depois uma prorrogação de mandatos contra a letra constitucional. E não eram nem comunistas, nem fascistas que assim tramavam, eram vozes dentro do próprio Parlamento, principalmente da mais direta intimidade com o Catete. Para mais justificar os temores vinha ainda essa luta surda da presidência da República contra o governo do Rio Grande do Sul, ameaçado do mais completo desrespeito à sua autonomia, com uma insólita intervenção federal e com a liberdade de que gozavam os integralistas na sua violenta propaganda (DUARTE, 1977, p. 6).

Ao relembrar os acontecimentos que precederam o golpe de 1937, Paulo Duarte destaca a primeira "rachadura no bloco político de Armando de Salles Oliveira", sinal visível do processo de seu enfraquecimento político e da fragilidade dos acordos políticos e dos apoios firmados, mas não cumpridos. Além disso, ressalta a incoerência do pedido de estado de guerra, apresentado pelo Ministério da Justiça, José Carlos Macedo Soares, cujo discurso, até então, era justamente o contrário, era o de que reinava a "mais absoluta calma" no país:

Há poucos dias o ministro da Justiça declarava em S. Paulo que o País estava na mais absoluta calma e que não havia nada que justificasse qualquer inquietação. Apenas, três dias depois, surge esse estranho e misterioso relatório dos ministros militares e é o mesmo ministro da Justiça que, encaminhando-o, solicita o estado de guerra! $\mathrm{E}$ um pedido dessa ordem vem desacompanhado de qualquer documento! Onde está essa alegada comoção intestina? Comoção intestina é coisa que se vê e sente, é coisa palpável, e o país inteiro só dela toma conhecimento por uma notícia enviada pelo ministro da Justiça ao Parlamento e desacompanhada da menor prova $(1977$, p. 3).

Mas as denúncias e apelos dos constitucionalistas não surtiram efeito no sentido de angariar apoio por parte dos políticos e tampouco dos militares. No Senado, o projeto para a decretação do estado de guerra foi aprovado por 22 votos 
contra 3, dados por Paulo Morais Barros, Cesário de Melo e Jerônimo Monteiro. Estes três políticos que, segundo Paulo Duarte, "não se haviam submetido ao terrível processo de emasculação moral"(1977, p. 6). Aprovado o projeto, Getúlio Vargas imediatamente baixou o decreto declarando o estado de guerra pelo prazo de 90 dias, em todo território nacional, sob a alegação de "comoção intestina grave", articulada no país com a finalidade de subverter as instituições políticas e sociais. Com o decreto, suspendiam-se todas as garantias públicas e privadas, que era finalmente o que se tinha em vista com a declaração do estado de guerra. Nessa suspensão, evidenciava-se o projeto varguista de continuar no poder sob argumento de que necessitava de tempo e dessas condições excepcionais para realizar as reformas exigidas para a modernização do país. Durante 90 dias o Brasil permaneceria, na avaliação de Paulo Duarte, "no rol das nações politicamente mais atrasadas do mundo, sob uma medida de exceção", algo que somente uma ameaça de invasão estrangeira ou a máxima calamidade interna poderia justificar, mas que foi declarada com base em justificativa infundada, sem o peso exigido para tal.

As cisões, traições, recomposições e alianças começaram a surgir, redesenhando o cenário político nacional e paulista. Afirmava-se que o governador de São Paulo, Cardoso de Melo Neto, apesar de ter sido antigo membro do Partido Democrático, de ter aderido posteriormente ao Partido Constitucionalista, preparava o seu rompimento com Armando de Salles Oliveira. Tudo indicava que, no caso de um golpe de Estado, Cardoso de Melo Neto permaneceria à frente do governo paulista com o apoio de Alcântara Machado. Vargas entregaria a ele a direção da política em São Paulo. De acordo com Paulo Duarte, o próprio Fábio Prado já havia alertado a todos sobre essa possível traição:

"O Cardoso", dizia ele, "fatalmente acabará brigando com o Armando. Em primeiro lugar, porque ele anda furioso com a intromissão dos agentes diretos do Armando em seu governo" - o que era verdade - "e, em segundo lugar, um governador de Estado por muito digno que seja quer fazer o seu governo e não governar dirigido de longe pelo seu antecessor, embora essa direção fosse apenas para não quebrar uma linha política preestabelecida" (DUARTE, 1977, p. 8).

Percebemos que Armando de Salles Oliveira também intervia na administração do governo que ele entendia estar subordinado a ele. Todavia, mesmo diante da decretação do estado de exceção, Armando de Salles Oliveira 
ainda não se dava por vencido. Em 6 de outubro, o candidato paulista anunciou uma caravana à Bahia. De acordo com Paulo Duarte, como o norte era a região estratégica de José Américo de Almeida, candidato de Getúlio Vargas, o paulista Armando de Salles Oliveira planejava ir não apenas à Bahia, mas também estenderia sua viagem a Pernambuco, ao Maranhão e à Paraíba, regiões de domínio getulista 77 "para cutucar a onça na sua própria toca" (DUARTE, 1977, p. 9). Essa disputa acirrada é objetivamente identificada por Getúlio Vargas que faz uma precisa avaliação do momento político atravessado pelo país após a decretação do estado de guerra: o de complicação do panorama político. Nos seus registros, o presidente assinala o seguinte:

(13 a 15/10/1937) O panorama da vida política no Brasil vai se complicando. Os partidários dos dois candidatos começam a vacilar. O Sr. Armando Sales, perdida a esperança na vitória, pensa delegar poderes ao governador do seu estado para tratar com o de Minas a escolha de um terceiro candidato. Na Câmara, uma certa corrente de opinião trata da prorrogação dos mandatos. Entre os militares, há um certo grupo partidário do Sr. Armando Sales que disfarça sua atitude, manifestando-se contrário às medidas tomadas pelo governo. $O$ ministro da guerra, porém, prepara com decisão a marcha dos acontecimentos. Assinei dois decretos requisitando as polícias militares de São Paulo e Rio Grande (VARGAS, 1995, p. 74).

Com efeito, com o decorrer dos dias e da campanha eleitoral, a situação política do país que permanecia em estado de guerra, se complicou intensamente. Em 19 de outubro, o governo federal requisitou, isto é, colocou à disposição das forças federais, a Força Pública de São Paulo e a Brigada Estadual do Rio Grande do Sul. Tratou-se de enérgica e rápida reação do governo Vargas contra uma possível união armada entre São Paulo e Rio Grande do Sul. Tal iniciativa que provocou uma reação até então inesperada por parte de Flores da Cunha: o governador riograndense renunciou e buscou refúgio em Montevidéu, no Uruguai. Era certamente a atitude que o governo Vargas esperava. Afinal, o lugar do ferrenho

\footnotetext{
${ }^{77}$ Todo o planejamento da visita de Armando de Salles Oliveira ao Norte e Nordeste do país encontra-se no arquivo Paulo Duarte. O projeto de promoção do candidato incluía uma excursão da "Grande Companhia Paulista de Comédia" pelas capitais do Norte e do Nordeste. A excursão da companhia teria a finalidade de apresentar um espetáculo de caráter "nacionalista, econômico e político". De acordo com o documento de planejamento da excursão: "um dos pontos principais de uma campanha política em favor de uma candidatura paulista é a de convencer-se o Brasil de que o Estado de São Paulo deseja firmemente a unidade nacional. Assim, destruir-se-á a pecha de separatista atribuída ao povo paulista, intriga política que será, fatalmente, uma das grandes armas a ser empregada contra São Paulo durante a campanha". (Arquivo Paulo Duarte, PD/ASO, pasta 37, n. 228).
} 
opositor, Flores da Cunha, foi ocupado pelo interventor nomeado por Vargas, o general Daltro Filho. Este, finalmente, "conseguiu um governo estadual!", comentou Paulo Duarte, que criticava Dutra desde a Revolução de 1930, alegando que ele teria interesse ascender ao poder a qualquer custo. A União Democrática Brasileira agiu imediatamente. Três dias após a fuga de Flores da Cunha, requereu ao Tribunal Eleitoral o registro da candidatura de Armando de Salles Oliveira, como candidato à presidência da República. Mas o homem forte da oposição a Vargas em seu projeto estava no exílio.

O ambiente político era pois de grande inquietação, com a intriga no seio do Exército, as pressões dos tenentistas, dos partidários de José Américo de Almeida, da oposição dos paulistas, insistindo e disseminando a propaganda política da candidatura de Armando de Salles Oliveira. Os boatos eram de que não haveriam eleições em três de janeiro; falava-se também na prorrogação do mandato do presidente da República. Boatos que se intensificaram quando alguns círculos políticos ligados ao candidato José Américo de Almeida anunciaram a retirada de sua candidatura. Não obstante esse movimento de debandada, Armando de Salles Oliveira seguiu firme em sua campanha política, com o apoio do grupo d'O Estado de S. Paulo e a simpatia de um grupo de militares que disfarçava sua posição de apoio à candidatura paulista, "manifestando-se contrario à medidas tomadas pelo governo Vargas" (DUARTE, 1977, p. 74).

Não por acaso, por ocasião das eleições para sucessão presidencial, o jornal O Estado de S. Paulo voltou a publicar em seu interior o "Jornal do PC", uma espécie de caderno político do Partido Constitucionalista que havia sido criado na época das eleições para a Assembleia Estadual Constituinte, em $1934 .^{78}$ Fonte importante para pesquisa da cultura política paulista nos momentos que antecederam o golpe, o caderno era reproduzido também em outros grandes jornais de São Paulo e do Rio de Janeiro ${ }^{79}$. A campanha eleitoral seguia e, não fossem os

\footnotetext{
${ }^{78}$ Durante a campanha eleitoral para a Assembleia Estadual Constituinte, em 1934, o caderno Jornal do PC era publicado diariamente. Já para a campanha às eleições presidenciais, o caderno teve publicação semanal. Para mais informações a respeito da campanha estadual de 1934, ver SOUSA, Carolina S. Política, a arte de lembrar e de esquecer. Dissertação de mestrado, UnB, 2012.

${ }^{79}$ No Arquivo Paulo Duarte encontra-se documentos referentes à articulação entre o jornal $O$ Estado de $S$. Paulo, que publicava o caderno Jornal do PC, e outros jornais de São Paulo e do Rio de Janeiro. Possivelmente o Partido Constitucionalista encomendava matérias pagas dentro dos jornais e também a publicação semanal do Jornal do PC. No Rio de Janeiro o responsável pela articulação com a imprensa era o jornalista Vivaldo Coaraci, membro do grupo armandista. O jornal $A$ Batalha era um dos jornais que apoiavam a campanha armandista no
} 
planos que estavam sendo articulados concomitantes a ela por parte do presidente Getúlio Vargas, dentro de alguns dias outro presidente seria escolhido para governar o país.

Paulo Duarte comenta os bons resultados numéricos conseguidos graças à campanha eleitoral realizada pelo Partido Constitucionalista. Os dados até aquele momento eram de oitocentos e cinquenta mil eleitores que haviam se alistado para votar. O alistamento eleitoral da população apta a votar era uma das bandeiras defendidas pelas caravanas que o Partido Constitucionalista realizou com Armando de Salles Oliveira pelo país durante a campanha eleitoral. No arquivo de Paulo Duarte há registros de que essas caravanas percorreram a região do Nordeste, região onde Salles Oliveira não tinha grande apoio devido à candidatura de José Américo de Almeida. No entanto, como a campanha eleitoral foi precocemente interrompida, o plano de percorrer todo o território nacional com as caravanas divulgando o programa políotico do partido e o pensamento de Armando de Salles Oliveira não pode ser completamente executado.

No pesado jogo político do momento, uma viagem do deputado Negrão de Lima $^{80}$ ao nordeste do país causou ainda mais inquietação em Paulo Duarte, em razão dos objetivos associados à iniciativa. Na avaliação de Duarte, a viagem daquele deputado ao nordeste tinha em vista negociar apoio para prorrogação do mandato de Getúlio Vargas:

Ao que parece, a missão de Negrão de Lima foi a de propor, a troco de vantagens políticas e pessoais, aos governadores de Estado, a prorrogação do mandato do presidente da República, dilatação por mais seis anos do dos demais governadores, dissolução da Câmara e do Senado e dos legislativos, estaduais, criação de uma câmara corporativa e de um conselho de técnicos que funcionará junto aos ministérios. Puro fascismo, mas Getúlio é apenas um caudilho, esse negregado fenômeno sul-americano, herdado dos espanhóis. O que ele quer é permanecer no poder. Não tem nenhum gosto ou predileção por este ou aquele regime, desde que seja ele o chefe, o presidente, o ditador, o rei, o imperador, o dono (DUARTE, 1977, p. 53).

Rio de Janeiro. (Arquivo Paulo Duarte, PD/ASO, p. 37, n. 201).

${ }^{80}$ Francisco Negrão de Lima, deputado federal por Minas Gerais entre 1935 e 1937. Em outubro de 1937 teve início o que ficou conhecido como "Missão Negrão de Lima", que consistia em uma viagem do deputado as regiões do Norte e do Nordeste para contatar os governadores dos estados daquelas regiões, comunicando-lhes os pontos básicos de uma possível mudança institucional e sondando suas posições a respeito de um possível golpe de estado (OLVEIROS, 2007). 
Paulo Duarte faz também uma avaliação percuciente das pretensões continuístas e caudilhistas de Getúlio Vargas. O objetivo deste é exclusivamente o exercício do poder, sem simpatia por esse ou aquele partido ou candidato, sem predileção por este ou aquele regime. Com tais propósitos e interesses, Vargas atuava disposto a chegar a acordos que Ihe fossem convenientes, como esse com os governos estaduais. Daí enviar o deputado Negrão de Lima para negociar com os governadores, sem que o presidente ficasse comprometido. Em 8 de novembro, José Carlos Macedo Soares demitiu-se do Ministério da Justiça, alegando cansaço. “Cansaço ou remorso?', perguntava-se Paulo Duarte. Afirmava-se que era por causa do suposto golpe de estado tramado por Getúlio Vargas com o apoio dos militares e Francisco de Campos ${ }^{81}$. Este conhecido jurista, fundador da Legião Revolucionário em Minas e, ao que tudo indicava, vinculado ao integralismo, foi o novo Ministro da Justiça de Vargas. Segundo avaliação de Paulo Duarte, a saída de José Carlos Macedo Soares não significou grande desfalque nas forças do governo federal, mas sua substituição por Francisco de Campos foi a grande virada no jogo político. Paulo Duarte se refere à entrada de Francisco Campos como uma guinada no jogo político porque foi o novo Ministro da Justiça que, em nome de Getúlio Vargas, articulou o apoio de Plínio Salgado e dos integralistas ao golpe de novembro de 1937. Para convencer Plínio Salgado de que apoiar Vargas era o melhor caminho, Francisco Campos garantiu que o integralismo seria a base da futura organização ditatorial que se almejava construir. (VICTOR, 2012). Logo em seguida a nomeação de Francisco Campos, os constitucionalistas se reuniram na casa de Armando de Salles Oliveira, no Rio de Janeiro, com integrantes da União Democrática Brasileira com o intuito de tomar deliberações sobre qualquer possível golpe ou perturbação da ordem. A atmosfera estava pesada.

No dia seguinte, o jornal de oposição paulista, Correio Paulistano, publicou artigo dizendo que a candidatura de Armando de Salles Oliveira estava morta, mas que teria seu atestado de óbito no dia 3 de janeiro, já que as eleições se realizariam, sim, "porque há a assegurá-lo a palavra o chefe da Nação e das mais altas autoridades das Forças Armadas, que não hão de querer o soçobramento da nacionalidade na desordem e na anarquia" (DUARTE, 1977, p. 52).

\footnotetext{
${ }^{81}$ Francisco Campos foi consultor geral da República entre os anos 1933-1937, sob o governo Vargas. A partir de 1936, a pedido de Vargas, começou a elaborar a Constituição que seria instaurada com o golpe de 1937.
} 
Os constitucionalistas, apesar dos boatos de golpe, tinham razões, embora frágeis, de manterem algumas esperanças quanto à possibilidade das eleições. Ainda na véspera, Armando de Salles Oliveira havia recebido a informação de que um golpe de Estado estava iminente. Todavia, o grupo militar de oposição, formado por Eduardo Gomes e outros chefes militares, buscou tranquiliza-lo, afirmando que não havia nenhum ambiente para golpes, não conseguindo, porém, convencê-lo. Afinal, seus informantes haviam confirmado que um golpe estava sendo tramado. Decidiu então escrever o manifesto que, na tarde do mesmo dia 9 de novembro, foi lido na Câmara e no Senado; ou seja, jogou sua última cartada.

Segundo Duarte, no âmbito das eleições, o ambiente era aparentemente pacífico, pois, mesmo depois da decretação do estado de guerra, a campanha eleitoral se fazia em nível intenso e sem que qualquer incidente tivesse sido registrado. Daí a ingenuidade ou dificuldade em acreditar num possível golpe de Estado, mesmo diante das medidas extraordinárias adotadas pelo governo federal. Não haveria aí uma falta de visão política? Afinal, as medidas excepcionais que o governo federal tomou contra os Estados demonstravam que não se tratava efetivamente de prevenir-se contra uma ameaça comunista, que era, de fato, inexistente. Na avaliação de Duarte, a medida era um artifício legal para o exercício de um grave desmando: que prorrogava os mandatos e mantinha Getúlio Vargas na presidência da República.

Também podemos avaliar o registro de Paulo Duarte, a surpresa diante de um golpe iminente, como uma ingenuidade conveniente, uma vez que políticos paulistas também participaram das medidas que acabaram por distanciar o país de uma eleição democrática. Diante desse quadro, Salles Oliveira redigiu o manifesto, denunciando o golpe que estava sendo articulado sob o regime de exceção do "estado de guerra". Lido no dia 9 de novembro, na Câmara e no Senado, o manifesto provocou alguma comoção, sem conseguir no entanto atingir a intenção de seu autor: convencer a maioria dos parlamentares à adesão da proposta armandista. Paulo Duarte centra sua crítica na ação dos militares, responsáveis pelo apoio militar à proposta de "estado de guerra", desculpando a fraqueza ou leniência dos parlamentares que se omitiram e/ou aprovaram a medida de exceção:

Não era possível que os chefes militares tivessem perdido o senso de dignidade ao ponto de faltarem à palavra empenhada, quando 
pediram o estado de guerra. Mas o fato é que faltaram. Mais uma vez, os militares falhavam, e como falhavam! (DUARTE, 1977, p. 55).

Paulo Duarte critica a ação dos militares e sua abstenção na defesa da legalidade da Constituição sem se dar conta de que aqueles também agiam por interesses próprios e que estavam em acordo com Vargas. Assim o dia 10 de novembro amanheceu calmo em São Paulo, "mas logo no fim da manhã começou a escurecer". Os boatos tomaram conta do país. Falava-se sobre um golpe de Estado e também sobre um golpe por parte do Exército contra Getúlio Vargas. Apenas à tarde vieram as primeiras notícias concretas. "A realidade era a mais melancólica": os militares, ao invés de "falharem", haviam se aliado a Getúlio Vargas. O Parlamento foi fechado no final da tarde. O chefe do governo central falou ao início da noite. Paulo Duarte comentou o discurso de Vargas, encerrando seu capítulo de memórias a respeito dos acontecimentos que antecederam o golpe do Estado Novo:

\begin{abstract}
O seu discurso foi de um cinismo ímpar. Os militares que o apoiaram e os políticos que o seguiam ou aderiam à última hora ficariam rubros de vergonha se neles houvesse brio pessoal, civil ou militar. Só mesmo um país em pleno esfacelo poderia tolerar semelhante mistificação. Mas tolerou e iria tolerar por oito longos anos de escuridão política, moral e mental (DUARTE, 1977, p. 57).
\end{abstract}

As memórias narradas por Paulo Duarte constroem seu compromisso com a defesa dos ideais constitucionalistas e democráticos do grupo político armandista e, sobretudo, um compromisso antivarguista, embora tenha atuado na administração de uma interventoria indicada por Getúlio Vargas. Ao invés de fazer a crítica dessa participação no mínimo questionável de seu grupo político, que optou por fazer uma aliança com Getúlio Vargas, Paulo Duarte significa tal relação como "imperativo" de sobrevivência ou de afirmação do grupo político armandista. A percepção a respeito dos membros de seu grupo político, principalmente de Júlio de Mesquita Filho e de Armando de Salles Oliveira, só mudaria durante o exílio. A expectativa de luta e vitória contra Getúlio Vargas foi frustrada diante da excessiva cautela de seus companheiros. Mas algo que Duarte não avalia é que a expectativa foi também frustrada pela força de cooptação de Getúlio Vargas, de sua base de apoio político e militar. Num movimento imperativo e pragmático de políticos e militares que escolheram transigir, negociar e aderir aos planos varguistas para poderem sobreviver, algo que o grupo paulista não estava disposto naquele momento. 
Com o regime do Estado Novo, veio a perseguição política aos seus opositores e Paulo Duarte foi obrigado a enfrentar seu segundo exílio. Partiu rumo à Alemanha, já dominada pelo nazismo, desembarcou no porto de Hamburgo, em dezembro de 1938. Poucos dias depois deixou a cidade de Hamburgo, passando por Colônia, Mannheim e de lá seguiu para Paris, onde viveria pelos próximos quatro meses. Foram também para o exílio político alguns de seus companheiros da jornada política dos últimos cinco anos, período em que os paulistas estiveram à frente do governo de São Paulo. Eram eles: Armando de Salles Oliveira, Julio de Mesquita Filho, Luiz Piza, Otávio Mangabeira, Mário Brandt e Paulo Nogueira Filho. Esse grupo reduzido será o responsável por algumas ações tomadas contra a ditadura estadonovista.

\title{
3.3. "Prisão, exílio e luta": mais que fantasmas; exilados propondo ações, articulando reações
}

\begin{abstract}
Não nos importa o momento que passa, cheio de apreensões, mas de tão aguda crise que, por certo, estará resolvida dentro de pouco tempo. A verdade é que atravessamos um instante de transição e o que vier daqui a pouco não poderá ser pior do que está aí. Ao contrário, o sofrimento, a experiência, a luta, tudo indica que o movimento mental iniciado em São Paulo, desde o governo de Armando, terá que ir por diante. Afastados presentemente da política, não nos é possível, por enquanto, colaborar mais eficientemente na execução de tudo quanto se delineou e se iniciou, quando o poder esteve em nossas mãos. Uma coisa, porém, podemos fazer. É defender e evitar que os espíritos obscuros destruam o que foi feito. Pensando nisso, pensando também no chômage em que nos encontramos, delineamos a execução de uma idéia capaz de satisfazer tudo ao mesmo tempo (DUARTE, 1976, p. 211).
\end{abstract}

$\mathrm{Na}$ avaliação de Paulo Duarte, o golpe do Estado Novo interrompeu o "movimento mental" iniciado em São Paulo a partir da administração de Armando de Salles Oliveira como interventor/governador e candidato à presidência da República. O que aquele chama de "movimento mental" é justamente o que entendemos por projeto político paulista, que passava pela ideia de um forte partido nacional sob a liderança de São Paulo, bem como um modelo de governança baseado na experiência da administração armandista em São Paulo, tal como apresentado no primeiro capítulo desta tese. 
Como já assinalado, durante os anos 1930, o grupo armandista tinha grande expectativa no que diz respeito às possibilidades de viabilizar seu projeto político de poder. Entretanto, o golpe do Estado Novo colocou abaixo os projetos políticos de distintos grupos. Assim como os integralistas, que se sentiram traídos no acordo com Getúlio Vargas, os armandistas também reconheceriam obstadas as chances de chegar à presidência da República, via eleição de Armando de Salles Oliveira. Segundo Victor, os paulistas armandistas, com "um só golpe, perdiam o tempo presente e futuro" (VICTOR, 2012, p. 9). Ao não entrar em acordo com Vargas, em 1937, o grupo perdeu a possibilidade de continuar executando o projeto até mesmo no âmbito de São Paulo. Com o golpe de estado, perderam a possibilidade de alcançar o posto presidencial, tal qual almejavam. O "movimento mental" continuaria do exílio, mas muito mais como uma ilusão que com práticas efetivas.

Ao redigir suas memórias, durante a década de 1960, Paulo Duarte já conhecia evidentemente o desfecho frustrado dos projetos de seu grupo. Em 1946, com a queda da ditadura varguista, Duarte retornou do exílio e em seguida publicou Prisão, exílio e luta, obra onde narrou a atuação do grupo armandista no período que sucedeu o golpe de novembro de 1937 e os anos de exílio, posteriormente usado na composição de suas memórias. O que Paulo Duarte faz questão de destacar em sua narrativa memorialística é que, apesar e por conta da condição de exilados, sem a vantagem da condição do exercício do poder dos tempos do governo de São Paulo, o grupo armandista continuou a propor ações para manter e realimentar seu projeto político, com o propósito reorientado para a redemocratização do país. Assim, imediatamente após o golpe do Estado Novo, o grupo procurou reunir-se para estabelecer as estratégias de luta contra a ditadura de Vargas. Nas memórias de Paulo Duarte, ele relembra que:

Meus encontros com o Armando têm sido quase diários, salvo nos períodos em que me acho recolhido aos meus periódicos retiros espirituais na polícia. Ele está disposto a trabalhar duro contra a ditadura, seja em que condições for. $E$ ele, a não ser caso fortuito, acabará mesmo dirigindo o Brasil. Para isso, está constituindo equipes. Todos os problemas nacionais, ou grande número deles, já começaram a ser estudados, sob a direção de pessoa altamente competente, como os problemas econômicos estão com o Clóvis Ribeiro. Acaba ele de me designar para os problemas culturais. O instituto nacional de cultura acha-se cada vez mais a caminho. Já convoquei, pedindo estudos e artigos, diversas pessoas. Almeida Júnior, Fernando Azevedo, Anízio Teixeira, Julinho e Chiquinho Mesquita, Henrique da Rocha Lima, Dreyfus, o grupo do 
Departamento de Cultura, o grupo dos professores estrangeiros, Lauro Travassos, Álvaro e Miguel Osório de Almeida e outros; a todos já escrevi pedindo determinados estudos e pesquisas, sob o pretexto de um inquérito sobre sistemas educativos e culturais, para o Estado (jornal) (DUARTE, 1976, p. 285).

Mesmo com Armando de Salles Oliveira em prisão domiciliar, o grupo político não deixou de debater e alimentar seu projeto político sobretudo com estudos e pesquisas. Naquele momento, talvez tomado pela indignação, Salles Oliveira estava disposto a combater fortemente a ditatura e a melhor maneira de fazer isso era dando continuidade nos planos pensados pelo grupo, no "movimento mental" mencionado por Paulo Duarte. Apesar do golpe de estado, algumas diretrizes do pensamento armandista continuavam as mesmas: solucionar os problemas econômicos e também os problemas culturais e educacionais através do pensamento e ação de um grupo político experiente.

Antes de partirem para o exílio, políticos e intelectuais do grupo armandista tinham sido presos sob a acusação de estarem tramando contra o governo Vargas. Armando de Salles Oliveira, já no dia 11 de novembro, um dia após o golpe, teve sua prisão domiciliar decretada. No caso de Paulo Duarte e Júlio de Mesquita Filho, eles já tinham sido presos 11 vezes. Segundo Paulo Duarte, a ditadura varguista os vigiava, a liberdade do grupo parecia incompatível com o cerceamento imposto pelo Estado Novo. Normalmente Julinho de Mesquita e Paulo Duarte eram os armandistas mais visados; eram presos quase que simultaneamente.

Fui levado para mesma sala em que se encontravam o Julinho e o Cristiano Altenfender. Julinho me contou que ele fora o segundo a chegar. A primeira coisa que o carcereiro lhe dissera é que havia já preparado, ao lado da dele, a cama do dr. Paulo Duarte, que certamente viria. Era isso mesmo, quando eu chegava primeiro, o carcereiro me dizia que ia preparar a cama do dr. Julinho. A prisão de um está condicionada à do outro (DUARTE, 1977, 221).

Ao mencionar que a prisão de Julinho de Mesquita estava sempre condicionada à sua prisão, Paulo Duarte busca conferir importância ao seu papel político naquele momento, similar à do diretor do jornal O Estado de S. Paulo. Reconhecia-se, assim, como forte presença na oposição, como um político que causava transtornos para o governo ditatorial na mesma proporção que lideranças políticas como Julinho de Mesquita e Salles Oliveira. Além disso, Paulo Duarte 
refere-se a Julio de Mesquita Filho como "Julinho" sinalizando intimidade, uma grande proximidade por conta da luta comum contra Vargas e das perseguições e prisões comuns. Dois episódios em particular ganham destaque nas ações do grupo armandista como suspeitos de fazerem oposição ao regime vigente e que antecederam o exílio do grupo: a fundação do jornal clandestino Brasil e o levante integralista de maio de 1938, episódios narrados com detalhes por Paulo Duarte. Havia a suspeita de que Paulo Duarte e outros armandistas estariam envolvidos na edição do jornal clandestino Brasil, publicado e distribuído durante quase todo o ano de 1938, motivo das sucessivas sucessivas prisões para intimidar e encerrar a publicação do periódico. O Brasil foi elaborado justamente para ser um jornal clandestino de oposição, daí as duras críticas a ditadura varguista que ele veiculava.

$\mathrm{O}$ assalto de 10 de novembro manifestou-se inopinadamente dentro da fantasia de um governo forte. A fortaleza desse governo vamos verificando a mais de um mês. Esperava-se logo, para o dia seguinte, fossem baixados os decretos estruturais do novo regime. Em lugar deles, apenas leis sem nenhuma importância, paliativos e panos quentes, a mesma tapeação terapêutica de sete anos de absoluta falência revolucionária orientada no mesmo princípio de "deixar-se como está para ver como fica. [...] Não acreditamos em messianismos, porque sabemos História (DUARTE, 1977, p. 125).

Paulo Duarte está se referindo ao golpe do Estado Novo. O governo Vargas, ao qual Duarte referia-se somente como ditadura, apesar da desconfiança da origem do jornal, expressas nas sucessivas prisões de seus editores e colaboradores, , não tinha provas porém contra o grupo armandista. Segundo Paulo Duarte, como resposta ao jornal clandestino,

A ditadura, diante da inanidade dos seus esforços para descobrir onde e quem imprime o "Brasil", resolveu repicar fundando São Paulo um pasquim chamado "O Estado Forte". o primeiro número saiu a 25 de janeiro. É de uma sabujice sem nome (DUARTE, 1977, p. 129).

Muitos dos artigos do jornal clandestino eram redigidos pelo próprio Paulo Duarte, entre eles, uma biografia que fez de Getúlio Vargas, "deixando o governo furioso". O objetivo maior era fazer oposição, difamando Vargas, insinuando o que este era capaz para permanecer no poder, com o fim de mostrar os desmandos e alianças espúrias do governo Vargas. De acordo com Paulo Duarte, a composição do jornal Brasil era tirada nas instalações do próprio jornal O Estado de S. Paulo. O 
linotipista d'OESP levava para sua casa e depois alguém do grupo buscava. Paulo Duarte se gaba do fato deste jornal ser o único da oposição em circulação e de como perturbava o governo Vargas que não conseguia descobrir os responsáveis pela sua edição e distribuição. Paulo Duarte descreve como era feita a impressão e distribuição do jornal clandestino, impedindo que a polícia da ditadura chegasse àqueles:

Estou informado de que todas as pesquisas policiais em São Paulo, para descobrir os responsáveis pelo Brasil ficam reduzidas à sua impressão. As tipografias existentes estão sendo examinadas, uma por uma, pois desanimaram já das investigações em torno de Julinho, de mim e de alguns outros julgados capazes dessa temeridade. Isso me trouxe uma relativa tranquilidade porque a impressão jamais será descoberta pela polícia. O jornal está sendo impresso nas oficinas da Prefeitura, cujo diretor é Caldora, pessoa da melhor fidelidade. Quando poderão eles pensar que um jornal clandestino contra o governo poderia sair impresso de uma repartição da prefeitura, dirigida por Prestes Maia, homem de total confiança tanto de Getúlio, quanto de Adhemar de Barros? O difícil é fazer chegar até às oficinas a composição feita nas oficinas do Estado, com tipos usados só para isso, de um magazine adquirido por mim, mas essa composição é conduzida pelo próprio linotipista e o Caldora, no automóvel oficial do diretor da Gráfica Municipal, e depositada normalmente na oficina oficial com toda segurança, sem nenhum contato comigo, com o Julinho ou qualquer outro companheiro mais atrevido. Daí, o fato das buscas estarem sendo voltadas também para o Rio de Janeiro, onde talvez o único jornal oposicionista poderá estar sendo feito também (DUARTE, 1978, p. 54-55).

Percebemos que a oposição armandista foi ousada ao usar todo o aparato do estado para distribuir um jornal clandestino e de oposição ao governo vigente. Segundo Paulo Duarte, a circulação do Brasil não se limitou apenas a São Paulo e Rio de Janeiro, o que dificultava a confirmação do envolvimento do grupo armandista com a publicação de oposição ${ }^{82}$.

O Brasil", jornal clandestino que circulou no país inteiro, durante todo o ano de 1938, constitui um problema angustiante que a ditadura do Estado Novo não conseguiu decifrar. Daí o fato de haver-se instituído um premio de duzentos contos, quantia enorme para época, àquele

\footnotetext{
82 Não encontramos exemplares do jornal clandestino Brasil no Fundo Paulo Duarte, no CEDAE. De acordo com Duarte, ele evitava andar com edições do jornal ou guarda-las em sua casa, uma vez que as prisões eram recorrentes e inesperadas. Há uma cópia do primeiro número do jornal, datada de 03/01/1938, data em que deveria ocorrer as eleições presidenciais, no oitavo volume de suas memórias, Vou me embora para Pasárgada, 1978, de suas memórias.
} 
que conseguisse descobrir a maneira por que era feito (DUARTE, 1978, p. 54).

A publicação do jornal só foi interrompida com a partida de Paulo Duarte e Júlio de Mesquita Filho para o exílio, os editores responsáveis pela publicação do jornal. Entretanto, devido à falta de provas, não houve uma acusação direta por parte do governo Vargas quanto ao envolvimento do grupo armandista na publicação clandestina. Ao todo foram publicados 28 edições do Brasil, sendo que a última só foi distribuída quando o grupo já se encontrava em exilio na Europa, o que teria confundido ainda mais as autoridades:

O número que será distribuído uma semana após minha partida, que deverá ser pelo "Monte Pascoal", vapor alemão que, depois de Santos, passará em Hamburgo. Se eu partir, será pois o último número deste nosso jornalizinho que marcou para sempre a imprensa clandestina do Brasil. Durante um ano, deu dor de cabeça nos malfeitores de Filinto Muller. Sei que a polícia está certa ou, pelo menos, tem suspeitas veementes de que estou metido nisto. Mas, tais as precauções que tomamos, que se tornaram uma verdadeira disciplina que, até hoje, não conseguiram nenhuma prova, ou mesmo indício convincente de mais esse crime praticado por mim. E daqui a uma semana e pouco, caso eu embarque mesmo, o suplício deles voltará porque eu já estarei longe e não podia evidentemente ser o chefe de Brasil. O último número do Brasil será um tiro de inquietação na ditadura. $\mathrm{O} 28^{\circ}$ tiro de inquietação (DUARTE, 1977, p. $54)$.

A partida de Paulo Duarte, que idealizou e executou o Brasil, ao lado de Júlio de Mesquita Filho, e do restante do grupo armandista, interrompeu a edição do jornal clandestino. Todavia, permanecia o projeto de oposição ao governo Vargas e de luta em defesa de uma orientação democrpatica e constitucionalista para o país, sob a liderança de São Paulo e do grupo armandista. Como destaca Duarte: "haverá mesmo mais condições para que o "Brasil continue?". O Brasil, o jornal, está claro, porque, quanto ao outro, a nossa ação será permanente" (DUARTE, 1977, p. 54). Entretanto, no esforço para engrandecer a ação do grupo, Paulo Duarte parece dar demasiada importancia ao jornal clandestino. Afinal, na condição e ditadura, o governo Vargas sequer necessitaria de provas para prender os membros do grupo político armandista, assim como fez imediatamente após o golpe com Armando de Salles Oliveira. 
Esta posição de oposição incluía registrar eventos como o levante integralista de 1938, que conseguiu, segundo Paulo Duarte, encurralar Getúlio Vargas por alguns momentos. Em maio de 1938 membros da Ação Integralista Brasileira, articulados com outros grupos insatisfeitos com Getúlio Vargas, deflagraram um movimento armado contra o Estado Novo. Mais uma vez, Paulo Duarte quis registrar sua participação num movimento contra Vargas:

Fala-se muito em revolução ou golpe, sei lá! Está até marcado o dia 11, para o golpe, ao que parece, do Partido Integralista, mas afirmase que o Mangabeira e o Euclides, ambos presos no Hospital do Exército são os chefes... chefes presos há mais de três meses... Mas já foi adiado várias vezes o tal golpe. Parece a inconfidência mineira, só que agora ninguém será enforcado ou esquartejado, apesar da prosápia do ministro da justiça, que quer adotar a pena de morte (DUARTE, 1977, p.206-207).

No caso dos integralistas, o desejo de derrubar o governo era fruto da traição de Vargas após a implementação do regime ditatorial. Uma vez que o acordo por parte de Vargas não foi cumprido e a Ação Integralista Brasileira proibida de atuar enquanto agremiação política, os integralistas sentiram-se traídos. Plínio Salgado, chefe da AIB, e candidato à presidência por essa mesma agremiação, estava a par das intenções continuístas de Getúlio Vargas. Entretanto, no início de novembro, ciente de que Vargas não pretendia deixar que as eleições acontecessem, Salgado retirou sua candidatura à presidência do Brasil. O chefe integralista manifestou solidariedade à luta que Getúlio Vargas alegava travar contra a ameaça do comunismo. Houve uma articulação direta entre Plínio Salgado e Getúlio Vargas no processo que culminou com o golpe do Estado Novo. ${ }^{83}$

Ao apoiar os planos golpista e continuísta de Vargas, a expectativa de Plínio Salgado era a de participar do governo na condição de sua base política. Havia, inclusive, a promessa da pasta do Ministério da Educação ser concedida a um integralista. Entretanto, o plano de Vargas, ao aproximar-se de Plínio Salgado, era ter apoio da força política da força do movimento integralista e depois neutralizá-lo politicamente. Idêntica estratégia Vargas tentou usar com Armando de Salles Oliveira, ao convocá-lo para conversa em seu gabinete, tentando dissuadi-lo da candidatura, empreitada que não teve sucesso. Finalmente, quando Vargas incluiu a

\footnotetext{
${ }^{83}$ Para mais informações sobre a composição entre Plínio Salgado e Getúlio Vargas, ver VICTOR, Rogério L. O integralismo nas águas do Lete. Dissertação de mestrado, 2005, UFG.
} 
Ação Integralista Brasileira no decreto que determinava o fechamento de todas as agremiações políticas, Plínio Salgado compreendeu que havia sido enganado por Vargas, que suas expectativas de participação no Estado Novo não se concretizariam. De modo que as lideranças integralistas começaram a articular um golpe contra o governo. O descontentamento acabou por reunir outras forças políticas que se opunham entre si, integralistas e liberais, mas que tinham em comum a vontade de derrubar o Vargas. Segundo Victor:

Em janeiro de 1938, enquanto Vargas acenava com a possibilidade de entendimento, Salgado já se encontrava em franca conspiração. Efetivamente, o golpe que meses antes implantara o Estado Novo e a política empreendida pelo Estado nos meses seguintes conseguiu o imponderável: a aproximação entre setores liberais e integralistas. Mais amplamente ainda, desde os seus primeiros meses, a ditadura promoveu a aproximação entre os descontentes com o novo governo Vargas, seja pela interrupção do jogo democrático e pela consequente frustração da perspectiva de alguns grupos que pretendiam alcançar o poder por meio das eleições que ocorreriam em 1938, seja pela exclusão de alguns do poder (VICTOR, 2005, p. 21).

Aqueles que não aderiram aos planos continuístas de Vargas e ao golpe de estado de novembro de 1937, não sobreviveram no jogo político situacionista. Precisaram se articular, de modo que até mesmo políticos que antes estavam em lados opostos, passaram a compor para tentar derrubar o governo Vargas. Com efeito, embora Euclides Figueiredo ${ }^{84}$ e Otávio Mangabeira ${ }^{85}$ fossem declaradamente liberais, aceitaram conspirar ao lado dos integralistas. Em São Paulo, a articulação deveria passar pelos partidários de Armando de Salles Oliveira. Euclides Figueiredo

\footnotetext{
${ }^{84}$ De acordo com Mayara Souza, Euclides de Oliveira Figueiredo foi um dos maiores opositores de Getúlio Vargas. Em 1930, já com a patente de coronel, foi convidado a participar do movimento que deporia o presidente Washington Luís. Entretanto, recusou-se a colaborar com os rebeldes. Após a revolução de 1930, manifestou-se imediatamente opositor ao novo governo, chefiado por Getúlio Vargas. Foi um dos líderes militares da guerra civil de 1932, derrotado e exilado, o Coronel só retornou ao Brasil em 1934, com a anistia. (SOUZA, Mayara P. O que não devia ser esquecido: A anistia e os usos do passado na Constituinte de 1946. Dissertação de mestrado, 2010). Apesar de ter se filiado ao Partido Republicano Paulista, Euclides Figueiredo apoiou a candidatura de Armando de Salles Oliveira à presidência da República. Com o golpe do Estado Novo, continuou a fazer oposição a Vargas.

${ }^{85}$ Otávio Mangabeira se destaca entre os liberais envolvidos com o golpe integralista, pois compunha com o grupo de Armando de Salles Oliveira. Mangabeira, político baiano, foi Ministro das Relações Exteriores durante o governo Washington Luís (1926-1930). Opositor do governo provisório instalado com a Revolução de 1930 foi afastado do Ministério e exilado. Retornou ao Brasil com a anistia de 1934 e foi eleito Deputado Federal. Sofreu novo exílio em 1938 por fazer oposição na Câmara à ditadura varguista implantada com o golpe de novembro de 1937. (Dicionário Histórico Biográfico Brasileiro pós 1930. $2^{\circ}$ ed. Rio de Janeiro: Ed. FGV, 2001, acesso em 04/08/2015).
} 
procurou Paulo Duarte para que o grupo armandista se juntasse a eles. A ideia de Figueiredo era depor Getúlio Vargas e restabelecer a democracia no país, com a convocação imediata das eleições. Paulo Duarte levou a oferta até Armando de Salles Oliveira, que continuava em prisão domiciliar, sob constante vigilância policial, embora as visitas não fossem proibiodas. Duarte aconselhou Armando de Salles a não aderir ao movimento. Foi decidido então que o grupo ficaria de fora da conspiração, mas colaborariam com armas. Mais uma vez, Paulo Duarte supervaloriza sua influencia nas decisões de Salles Oliveira, colocando-se em posição de centralidade no grupo político armandista. A avaliação de Paulo Duarte desconsidera a experiência e o pragmatismo político de Armando de Salles Oliveira na decisão de não se envolver na ação promovida pelos integralistas.

De manhã, Fábio me acordou. Dera-se o levante integralista e metidos neles o Mangabeira e o Euclides! Há três meses tivemos em S. Paulo uma reunião com o Euclides, o qual nos comunicou que estava conspirando com o Fournier, dentro de um conluio integralista. Ele entrará em qualquer conspiração para derrubar o Getúlio, mas não quis faze-lo sem nos avisar. De qualquer maneira, disse ele, só colaborará para derrubar o Getúlio e jamais apoiará os integralistas. Na reunião achavam-se todos os nossos companheiros que possuem armas em depósito. São quase cem metralhadoras Schmeitzer distribuídas entre dez pessoas de confiança: Julinho, Chiquinho, Nélson Otôni, Oswaldo Porchat, Marcos Mélega, eu, Dalísio Mena Barreto e outros, todos com alguma quantidade de armamento e munição. Só eu tenho vinte metralhadoras, algumas ocultas em minha própria casa, mas em esconderijo formidavelmente secreto, inencontráveis por qualquer busca, a não ser que sejam algumas paredes demolidas. Mas nós não aderimos à conspiração integralista, que talvez fosse de pior resultado do que Getúlio. Dois companheiros acompanham o Euclides e pediram que the cedêssemos dez metralhadoras. Foi cedido esse armamento, ao Euclides pessoalmente, mas toda a responsabilidade dos companheiros (DUARTE, 1977, p. 206-207).

Armando de Salles Oliveira encomendou essas metralhadoras para uso da Força Pública ainda em 1936, quando estava à frente do governo de São Paulo. Com a sua renúncia e mudança do chefe da Força Pública, achou melhor recolhêlas e guarda-las em local seguro, caso algum dia pudesse precisar. Delegou que alguns membros de seu grupo político escondessem as metralhadoras. Paulo Duarte guardou cerca de vinte delas em sua biblioteca, entre as estantes de livros (DUARTE, 1977). Júlio de Mesquita Filho, apesar de concordar que seria melhor o grupo não se envolver diretamente com a conspiração, autorizou Paulo Duarte para 
entregar as metralhadoras. Pouco tempo depois da tentativa de articulação com o grupo armandista, os integralistas haviam provocado algumas agitações no Rio, que resultaram na prisão de Euclides Figueiredo e Otávio Mangabeira. Desde então seguiu-se a violenta repressão contra os conspiradores, o que não impediu o levante ou talvez o tenha precipitado. Com a prisão de Figueiredo e Mangabeira, quem comandou o assalto ao Palácio da Guanabara, em levante militar, foi Severo Fournier $^{86}$, que, de acordo com Paulo Duarte, era "corajoso até a loucura".

Mas, agora, Euclides estava preso, de modo que, o movimento arrebentara de madrugada, comandado por Fournier e alguns oficiais, mas todos mais ligados a nós do que a Plínio Salgado. Euclides e Mangabeira é que, da prisão mesmo, haviam traçado os planos. Havia, no entanto, muitos integralistas, mas sob o comando daqueles oficiais. Foram atacados, principalmente, o Ministério da Marinha e o Palácio Guanabara, residência de Getúlio. Aqui, sob o comando de Severo Fournier, com o mesmo denodo que revelara em 1932, os revolucionários chegaram a penetrar em dependências do palácio, tendo Vargas passado longas horas, até quase 0 amanhecer, arrastando-se pelos tapetes para escapar às balas. Quem o salvou foi o general Gaspar Dutra, que chegou com forças de socorro quando Getúlio se achava completamente abandonado. Os oficiais seus amigos omitiram-se, permanecendo nos quartéis, mas Dutra foi o único que, por conta própria, tomou a iniciativa e veio para o Guanabara com toda sua tropa e chegou a tempo de Salvar o ditador e sua família. A maioria dos atacantes pôde retirar-se pelos fundos do Palácio pelo irmão de Getúlio. Foram presos cerca de seiscentos civis e cerca de dois mil militares, soldados e marinheiros (DUARTE, 1977, p. 190).

O envolvimento no levante militar e integralista de 1938 de políticos e militares como Otávio Mangabeira, Euclides Figueiredo, pessoas próximas do grupo armandista e que não tinham simpatia pelos integralistas, revela que esta ação fazia parte de uma conspiração mais ampla de golpe contra o governo de Getúlio Vargas e que envolveu diversas lideranças contrárias a ele (NETO, 2013). Para Edgar Carone, o fato de outros membros pertencentes a diferentes grupos políticos terem apoiado a tentativa de golpe não deve ser analisado como relevante. Tais grupos já estariam excluídos da nova realidade política, diferentemente dos integralistas, que ainda eram parte integrante do sistema e das preocupações de Getúlio Vargas, haja

\footnotetext{
${ }^{86}$ O Tenente Severo Fournier foi homem de confiança de Euclides Figueiredo, tendo sido seu ajudante-deordens na guerra de 1932. Com a prisão de Euclides Figueiredo, Severo Fournier passou a ser o organizador militar do levante. Coube também a Fournier a missão mais importante do levante: assaltar o palácio da Guanabara e o aprisionamento do chefe do governo, Getúlio Vargas. (COUTINHO, Amélia. Dicionário Histórico Biográfico Brasileiro. CPDOC, acesso em 05/07/2015).
} 
vista seu empenho em neutralizar sua força política. A saída dos integralistas de cena representaria um fator a menos no jogo de poder, tornando o Estado Novo mais forte e estável (CARONE, 1977). Tal avaliação nos instiga a pensar as estratégias de Getúlio Vargas diante da necessidade de neutralizar diferentes grupos, forças políticas que poderiam ameaçar seu projeto continuísta. Entretanto, não nos parece procedente afirmar que tais grupos já estariam excluídos da nova realidade política. É importante perceber que os grupos políticos afastados do poder pelo golpe do Estado Novo continuaram se articulando e tentando mudar os rumos do jogo político. Dentro de suas expetativas, ainda era possível reverter o quadro e combater Vargas. No caso dos paulistas armandistas, a tentativa de neutralização aconteceu quando Getúlio Vargas investiu, sem sucesso, contra uma possível candidatura de Armando de Salles Oliveira, buscando convencê-lo a não se candidatar. Na avaliação de Paulo Duarte, a administração de Armando de Salles Oliveira em São Paulo, somado à sua capacidade intelectual e de oratória, transformaram-no em um candidato com força nacional, capaz de influenciar a decisão de Vargas de liderar o golpe que fundou o Estado Novo. Paulo Duarte faz questão de frisar que Salles Oliveira tinha possibilidades reais de alcançar a presidência da República, que representava uma forte ameaça à Vargas.

Todos os grandes políticos mundiais com os quais Armando tem conversado, são unanimes em falar do alto nível mental e da inteligência do ex-governador de São Paulo. Getúlio mesmo precisou dar um golpe de Estado para evitar que Armando, só com a sua obra em São Paulo e seus discursos, fosse eleito para presidência do Brasil (DUARTE, 1977, p. 255).

O golpe do Estado Novo interrompeu o projeto político armandista e de outros grupos que buscavam alcançar o poder durante a década de 1930. Entretanto, tanto no caso do grupo armandista como no dos integralistas, liderados por Plínio Salgado, a inserção no jogo político, a conquista do poder, ainda fazia parte da expectativa dos grupos derrotados pelo golpe do Estado Novo.

Depois do levante integralista, acentuou-se ainda mais a repressão do governo aos opositores do regime. Em São Paulo, as prisões de membros do grupo armandista foram cada vez mais frequentes. Paulo Duarte comenta que deixava sempre uma mala de roupas pronta, uma vez que poderia ser preso a qualquer momento, como vinha acontecendo desde o início de 1938. Finalmente veio o exílio. 
No relato de Paulo Duarte, ele exalta as qualidades de seu líder, Salles Oliveira, cuja têmpera não se deixava abater, enfrentando com destemor as vicissitudes, passando impávido por elas, como "um cisne" cujas penas as águas da chuva passam por elas "sem molhar ou deixar marca". Ao exaltar as qualidades do líder, Duarte, seu companheiro de longa data e de muitos combates, se reconhece como da mesma têmpera, mas não se identifica diretamente, num exercício de falsa modéstia. A história é que objetivamente o julgará. Em suas próprias palavras:

Armando de Salles Oliveira chegou a S. Paulo, de volta de sua prisão em Morro Velho, mais do que nunca disposto à luta. As vicissitudes que a tantos abateram passaram por ele como as águas da chuva passam pelas penas de um cisne, sem molhar ou deixar marca. Tomou imediato contato com os seus companheiros da mesma têmpera. E assim seria até a expulsão do país na companhia de alguns desses companheiros. E lá foram eles com serenidade e a decisão dos grandes combatentes, armados da certeza dos que têm razão (DUARTE, 1977).

Armando de Salles Oliveira e Júlio de Mesquita Filho foram os primeiros a receber a ordem de que deveriam deixar imediatamente o país. Diante da notícia, Paulo Duarte se dirigiu à casa de Armando, onde tiveram longa conversa a respeito das ações que deveriam ser tomadas dali em diante.

Julinho e Armando moravam em casas pegadas, à rua Gabriel dos Santos. Os dois prédios estavam vigiados por policiais à porta, mas deixavam a gente entrar. Armando estava na companhia de várias pessoas. Deixou-as e me levou para a sala de jantar. Foi longa a nossa conversa. Disse-me que a luta prosseguiria e ele contava comigo. Acenei afirmativamente (DUARTE, 1978, p. 41).

E foi nesse encontro que Salles Oliveira expôs seu plano de atingir a ditadura através de um navio, que ancoraria próximo à costa brasileira, com a finalidade de "informar o Brasil" contra Getúlio Vargas. Informar o Brasil, neste caso, era exatamente a ação de propaganda política contra a ditadura varguista, tendo em vista que a imprensa permanecia censurada.

Pois eu tenho uma ideia que há muito me está trabalhando, prosseguiu. O Brasil, disse ele, acha-se isolado do mundo e de si mesmo. Cada Estado é um compartimento estanque. Todos, sem nenhuma informação, fora aqueles que o governo quer. Pois nós vamos informar o Brasil. E expôs a sua ideia. Alugaríamos ou compraríamos um pequeno navio que viria passear pelo Atlântico, diante do Brasil, mas sempre fora das águas territoriais. E desse navio irradiaríamos toda a nossa campanha contra Getúlio e, ainda, 
notícias outras que nos conviessem. Para dirigir esse trabalho eu estava indicado. É claro que estaríamos todos juntos a bordo e só nos separaríamos quando o determinassem os interesses da campanha, mas eu seria efetivo na missão. Se eu não fosse atingido também por uma ordem de expulsão, ele me mandaria avisar o momento de embarcar para encontrar-me com ele. Pediu-me que meditasse nisso, e sugerisse o que, a meu ver, fosse útil à execução da ideia. Pouquíssimos saberiam, mas não me disse quem. Quanto ao dinheiro, ele tinha certeza de obtê-lo por qualquer organização europeia ou norte-americana que se bate contra as ditaduras. $E$ ele sabia já como principiar a ação na Europa. Foi o nosso último encontro (DUARTE, 1978, p. 41).

É possível apreender da fala de Armando de Salles a preocupação com o fortalecimento dos Estados diante do Governo Federal, já que avaliava que somente desse modo seria possível construir um regime político republicano e democrático, tal como vivido pelos países desenvolvidos. Paulo Duarte, conforme já esperado, fora enviado ao exílio em seguida. Assim, com o plano acertado de união dos armandistas no combate a Getúlio, o grupo deixou o país. Ao contrário de 1932, o número de exilados desta vez foi menor. Do grupo armandista, apenas cinco seriam os exilados: Armando de Salles Oliveira, Júlio de Mesquita Filho, Luíz Piza Sobrinho, Paulo Nogueira Filho e Paulo Duarte; Seriam exilados ainda Otávio Mangabeira, Mário Brandt e Lindolfo Color.

A ideia de uma embarcação com o objetivo de "informar o Brasil", isto é, rompê-lo do isolamento do mundo e de si próprio, entusiasmou Paulo Duarte e tornou-se objeto de debate recorrente entre o grupo durante o exílio, em Paris. A preocupação por parte de Paulo Duarte em corresponder às expectativas de Salles Oliveira e de Julinho de Mesquita e também às exigências projetadas para combater a ditadura era algo constante em suas memórias. É possível identificar tal preocupação na passagem de chegada ao exílio:

Julinho me mostrou ainda um cartão que Pacheco e Silva havia mandado ao Armando. Era de 20 de novembro. "Vai o Paulo também a caminho do exílio - dizia ele, purgando a culpa grave de ser um dedicado defensor da liberdade, dotado de um espírito indomável e, por isso mesmo, incomodo aos homens do Estado Novo. Será ele, como sempre, um excelente companheiro, leal e dedicado, destemeroso e sincero, tanto nas horas de triunfo, como na adversidade". Obrigado, Antônio Carlos. Mas agora é que vem a prova dura, vamos ver se correspondo (DUARTE, 1978, p. 107). 
Nesse exercício de memória, Paulo Duarte usa os testemunhos de outrem para fundamentar a representação que faz de si e também que seus companheiros dele fazem para alimentar a história que será escrita sobre si e seu grupo. Assim, o exílio não poderia amolecer a vontade de agir daquele grupo, sobretudo, esse "companheiro leal e dedicado, de espírito indomável". Logo nas primeiras horas de sua presença em Paris, apressou-se a ir ao encontro de Armando de Salles Oliveira. Afinal, era preciso discutir os próximos passos, não podiam ficar inertes, sem qualquer reação diante dos desmandos do governo Vargas:

Saímos Julinho e eu, da rue de La Pompe, em direção à rue Anatole de la Forge, onde Armando está morando num apartamento, com quase toda família: Rachel, Armandinho e Júlio. Fiquei satisfeito ao verificar a boa disposição com que Armando enfrenta a adversidade. Conversamos longamente sobre o nosso programa de ação, inclusive aquele projeto de que me falara em São Paulo, de montarmos uma rádio possante a bordo de um pequeno navio para, de águas internacionais, esclarecer o povo brasileiro sobre quem é Getúlio e seus cúmplices nessa aventura caudilhista desmoralizante que é o seu chamado Estado Novo. Armando me forneceu ainda jornais de São Paulo e do Rio, com os quais, à noite, eu ia me por a par do que acontecera no Brasil e no mundo. Combinamos de nos ver todos os dias e passar o Natal juntos (DUARTE, 1978, p. 108).

A narrativa de Paulo Duarte exibe um mal contido e escondido orgulho de fazer parte da intimidade de Salles Oliveira, convivência que, aos seus olhos, Ihe conferia prestígio. Outro exilado que demonstrou ser grande companheiro de Paulo Duarte, e por isso mereceu destaque em suas memórias, foi o exilado Paulo Nogueira Filho ${ }^{87}$, o Paulito, assim chamado pelo memorialista, para evidenciar mais do que relações políticas entre os dois. Ambos não puderam levar esposa e família com eles para o exílio, decidiram então dividir apartamento em Paris. Paulo Nogueira acabou se tornando confidente de Paulo Duarte no que diz respeito às suas mágoas em relação a Armando de Salles Oliveira e Júlio de Mesquita Filho.

\footnotetext{
87 Paulo Nogueira Filho se envolveu com a política ainda jovem, fazendo oposição ao Partido Republicano Paulista. Ajudou na fundação do Partido Democrático, em 1924, e na campanha da Aliança Liberal, que culminou na revolução de 1930. Em 1932, apoiou o movimento constitucionalista, lutando na guerra civil de 1932. Com a derrota dos paulistas, Nogueira Filho foi exilado, mas retornou ao Brasil no ano seguinte, sendo eleito deputado federal pelo Partido Constitucionalista, em 1934. Apoiou a campanha presidencial de Armando de Salles Oliveira. Com o golpe do Estado Novo, Paulo Nogueira Filho, contrário ao novo regime, foi preso e enviado para o exílio, junto com Armando de Salles Oliveira e outros membros do grupo armandista. Seu segundo período de exílio durou cerca de sete anos, durante os quais o político continuou lutando contra o Estado Novo ao lado do grupo armandista. (MAYER, Jorge Miguel. Dicionário Histórico Geográfico Brasileiro. FGV-CPDOC, 2001. Acesso em 30/07/2015).
} 
Dividiam também o anseio por derrubar Getúlio vargas, como reportado pelo memorialista: "Com quem estive longamente foi com Paulito, que está muito bem animado. A par das intenções do Armando só sonha conosco em mar alto atirando para o Brasil todas as verdades sobre Getúlio e sua corja" (DUARTE, 1978, p. 108).

Reunidos em Paris, o grupo começou a colocar as estratégias de luta em prática. Durante os primeiros dias do ano de 1939, o assuntou que tomou conta da imprensa foi a mensagem do presidente Franklin Roosevelt ao Congresso, transmitida para mundo inteiro. O presidente norte americano afirmava seu apoio às instituições livres e conclamava todos a defendê-las. O grupo enxergou na mensagem uma possibilidade de ação. Imediatamente Armando de Salles Oliveira convocou uma reunião em sua casa, com a presença de todos os exilados brasileiros, incluindo Mário Brandt e Otávio Mangabeira, para que tomassem conhecimento da carta que seria enviada ao Presidente Roosevelt em nome dos exilados, no dia 7 de janeiro de 1939, cujo teor era o seguinte:

Membros da União Democrática Brasileira, pleiteávamos no Brasil a eleição presidencial, em uma das campanhas mais expressivas de que se há notícia na sua história política, quando o presidente da República, sr. Getúlio Vargas, que se achava no poder havia já oito anos, surpreendeu o país declarando revogada a Constituição Federal e outorgando uma nova carta na qual se atribuiu a si mesmo um novo mandato de seis anos, suscetível de prorrogação. Ficou assim instituído o mais totalitário dos regimes, pois ali não há sequer nenhum dos simulacros que outras ditaduras admitem, como seja, por exemplo, o do funcionamento das câmaras. Não há vislumbre de liberdade de imprensa ou qualquer outra liberdade pública, nem se fala tão pouco em nenhum modo de pronunciamento pelo voto. Sob a responsabilidade oficial é feita propaganda sistemática dos governos de força, procurando incutir nos ânimos, aliás inutilmente, a doutrina da falência das instituições livres. Basta que se leiam estas palavras, que são do próprio governo, quando, outorgando ao país o Estado autoritário, pretendeu justifica-lo: "A liberdade individual e suas garantias não resolviam o problema do homem. Eram ideais negativos, que não garantiam aos indivíduos nenhuma bem concreto, seja no domínio econômico, seja no domínio moral, seja no domínio intelectual e político" (DUARTE, 1978, p. 116).

A citação final, reproduzida na carta, foi frase efetivamente proferida por Getúlio Vargas em seu primeiro pronunciamento como chefe do Estado Novo. Com tal carta, o grupo pretendia chamar a atenção de Roosevelt e da imprensa internacional para o que se passava no Brasil. Procuravam, com esta denúncia, preparar terreno para uma viagem política aos Estados Unidos, quando então 
pretendiam obter recursos junto ao governo americano para o projeto do navioestação que combateria a ditadura do Estado Novo. O plano parecia perfeito e viável e assim todos os exilados que se encontravam em Paris assinaram a carta. ${ }^{88}$. Entretanto, as ideias do grupo, diferente do projetado e esperado, não encontraram acolhida junto a Roosevelt.

A expectativa era de que a carta ao presidente Roosevelt produzisse efeito não só nos Estados Unidos, mas também na França. Para tanto, foram emitidas cópias traduzidas para o francês e para o inglês, distribuídas para a imprensa. Também foram feitas cópias em português, que seriam enviadas por Otávio Mangabeira aos políticos no Brasil, inclusive para todos os interventores dos Estados. Já os exilados se encarregaram de enviar cópias aos amigos no Brasil. De acordo com Paulo Duarte, a imprensa, apesar de não reproduzir toda a carta, deu grande atenção ao fato, fazendo com que muitos pedissem pelo conteúdo integral da mesma. Na avaliação de Paulo Duarte, a mensagem dos exilados ao presidente norte-americano foi positiva, embora sem resultados concretos e drásticos:

O Oswaldo Aranha chegou meio desapontado e, ao que parece, com recados severos de Roosevelt a Getúlio, mas este respondeu por um discurso reafirmando a sua estabilidade e dizendo que "nada temos com a organização interna de outros países como também não aceitamos interferências estranhas na nossa organização." É conhecida a quedinha da ditadura pela Alemanha, assim ele poderá provocar um conflito com os Estados Unidos (DUARTE, 1978. p. 138).

O envio das cópias de carta ao Brasil tinha o objetivo de que elas chegassem o mais rápido possível justamente ao conhecimento de Getúlio Vargas. Era preciso que o chefe do Estado Novo soubesse que os paulistas permaneciam agindo e fazendo oposição. Paulo Duarte narra episódio em que chegou até mesmo a fazer uma espécie de acordo com o diplomata brasileiro Paulo Silveira, que estava de remoção marcada para ser secretário na Embaixada Brasileira em Paris. Encontraram-se em Paris e, segundo Paulo Duarte, tal remoção ocorrera justamente para que aquele desempenhasse "as funções de olheiro de Getúlio Vargas" no que diz respeito aos exilados. De modo que o diplomata procurou Paulo Duarte para

\footnotetext{
${ }^{88}$ Além de estar reproduzida no sétimo volume das memórias de Paulo Duarte, Miséria Universal, Miséria Nacional e Minha própria miséria, 1978, há várias cópias da carta, semelhantes as que foram distribuídas na época, no Arquivo Paulo Duarte.
} 
oferecer seu serviço de "olheiro" também, uma espécie de agente duplo já que, no caso, traria também informações do governo brasileiro para o grupo armandista. Em troca, para manter seu posto em Paris, necessitava que os exilados o informassem de alguns passos para que pudesse manter Getúlio informado. Paulo Duarte achou o acordo vantajoso, repassou os termos para Armado de Salles Oliveira e este concordou. Era importante que Getúlio Vargas fosse informado das ações de oposição dos exilados (DUARTE, 1977).

Uma fraca oposição, pois reduzida às cartas enviadas pelo grupo, que tornou-se a principal tática de luta a ser exercida naquele momento; enviá-las ao Brasil significava dar voz e visibilidade ao grupo exilado. Paulo Duarte acreditava no poder de intervenção dessas correspondências, caso fossem entregues em mãos certas. Nesse sentido, com a concordância do grupo de exilados, Armando de Salles Oliveira redigiu e enviou uma carta ao General Góes Monteiro ${ }^{89}$, líder militar que já acenara em outras vezes suas diferenças e suas disputas com Vargas:

Armando acaba de enviar uma carta a Góis Monteiro, que eu fiz imprimir imediatamente em mil folhetos, para sua distribuição. Não me esqueci de dar um exemplar prioritário ao Paulo Silveira, que já o enviou diretamente ao Getúlio, pois ele se comunica diretamente com o ditador, não dando a menor confiança ao Itamaraty... trata-se de uma mensagem que marcará a história da política brasileira (DUARTE, 1977, p. 141).

Ao avaliar que a mensagem contida na carta, e que seria enviada a Vargas, "marcará a história da política brasileira", Duarte, menos do que arrogância, revela certa ingenuidade e/ou romantismo, que o impede de perceber que aquela iniciativa não teria peso para mudar os rumos políticos do país. Apostava no poder da palavra de uma carta cuja causa, se abraçada pelas pessoas certas, mudariam a política brasileira, pois aquele era um "documento de lucidez e coragem notáveis. Um cáustico no lombo da ditadura". Segundo o memorialista, o documento "ficou conhecidíssimo no Brasil, com grande desespero e ira ditatorial” (DUARTE, 1978, p. 142). Mas não mudou o regime, sequer fragilizou a ditadura.

\footnotetext{
${ }^{89}$ Góes Monteiro foi Ministro da Guerra, nomeado por Getúlio Vargas, em 1934. Em 1935 deixou o ministério, mas continuou participando e influenciando o governo de Getúlio Vargas. Foi um dos elementos centrais do golpe de Estado de 1937. (Dicionário Histórico Biográfico Brasileiro pós 1930. 2a ed. Rio de Janeiro: Ed. FGV, 2001).
} 
As cartas escritas durante o exílio do grupo armandista, sobretudo as escritas por Armando de Salles Oliveira, constituem importantes registros acerca da situação política e dos sentimentos vivenciados pelo grupo armandista após o golpe de novembro de 1937 e durante o exílio. Daí o interesse de Paulo Duarte em guarda-las em seu arquivo político, ${ }^{90}$ para assegurar a precisão daqueles e sobretudo a visão dos vencidos nos acontecimentos do período Vargas (1930-1945). As cartas então são vistas como testemunhos da verdade dos fatos e das ideias e projetos dos armandistas, particularmente seu líder, Salles Oliveira. Não por acaso, segundo Paulo Duarte, aquele político sempre o consultava para escrever tais cartas, o que o torna duplamente testemunha. Nelas, Armando de Salles Oliveira reafirma e repisa os passos que levaram o grupo ao exílio, na tentativa de compreender os motivos de sua derrota. Por vezes, aparece frustrado, enquanto exilado, ciente de sua condição de inaudível. Nessa condição de distante do país e distanciado da política, o único meio de se fazer ouvir seria através das cartas enviadas, como ele expõe sua frustração ao General Góes Monteiro:

É possível que V. Exa. não vá até o fim desta carta; a voz de um exilado talvez chegue aos seus ouvidos como um som de além túmulo, inoportuno, desagradável. No momento em que no Brasil não se fala e não se escreve senão sobre realidades, compreendendo que não haja tempo para ler e ouvir fantasmas (OLIVEIRA, 2002, p. 445).

A avaliação realista da condição de exilado de Armando de Salles Oliveira diverge da construída daquela por Paulo Duarte, perpassada por idealismo romântico, para quem o grupo exilado incomodava de modo significativo a ditadura. A estratégia do envio das cartas tinha em vista quebrar o isolamento dos exilados que manifestavam nelas suas primeiras desilusões na luta contra o Estado Novo. Era, literalmente, uma forma de conferir sentido à luta travada e à condição de exilados. Cartas enviadas a antigos aliados políticos no Brasil e os pedidos de favores muitas vezes eram ignorados, revelando o distanciamento, enfraquecimento e nostalgia que o exílio provoca ao exilado, individualmente ou em grupo. $\mathrm{Na}$ França, a recepção também não era muito promissora, como a condição de exilados fazia com que políticos, a quem o grupo pretendia pedir auxílio, se esquivassem.

\footnotetext{
${ }^{90}$ Assim como a carta enviada ao Presidente Roosevelt, o original e várias cópias da carta destinada ao General Góes Monteiro encontram-se no Arquivo Paulo Duarte (PD/ASO, p. 43).
} 
Sem ajuda dos pares no Brasil e seu apoio internacional, o plano de um navioestação para fazer oposição ao ditador parecia-se cada vez mais uma miragem, um projeto ilusório.

A princípio, o grupo de exilados permaneceu unido. Até mesmo aqueles que estavam na condição de opositores do Partido Constitucionalista, entre 1934 e 1937, durante o exílio se aproximaram do grupo armandista. Havia um elemento comum entre eles: a condição de exilados, de opositores e de indesejáveis ao governo. Paulo Duarte relata que todos os dias os exilados reuniam-se no Café Napolitano, no Boulevard des Italiens, em Paris. Convivência que aquele nem sempre podia usufruir, uma vez que sua condição financeira era precária. Aliás, uma questão cara a Paulo Duarte era justamente sua precária situação financeira, que lhe trouxe muitas dificuldades no exílio, situação que posteriormente será motivo de mágoas e ressentimentos em relação a Armando de Salles Oliveira:

Daí para cá, outra coisa não tenho feito senão procurar, de maneira pública, restaurar por meio honesto a minha precaríssima situação econômica, seriamente comprometida por três anos de absoluta dedicação à obra construtora de Armando de Salles Oliveira, da qual São Paulo, o verdadeiro São Paulo, nunca esquecerá (DUARTE, 1977, p. 23).

Paulo Duarte entendia que tinha dedicado boa parte de sua vida ao projeto político de Armando de Salles Oliveira, atribuindo justamente a essa dedicação a razão de nunca ter alcançado uma estabilidade financeira, que seria útil durante o exílio. Havia, portanto, um ressentimento com Salles Oliveira. Entretanto, esse sentimento era comum a outros membros do grupo, fazendo com que estes eventualmente esquecessem as querelas internas e lembrassem que o responsável pela situação de exílio que eles estavam passando era Vargas e não Salles Oliveira. O maior ressentimento nas memórias escritas por Duarte é com relação à ditadura varguista. Segundo Pierre Ansart (2004):

Se somos vítimas de indivíduos que nos prejudicam e ferem nossas liberdades, experimentamos e estimamos que estes indivíduos sejam malévolos, enquanto nós seríamos os bons. As forças que me são hostis são nefastas e perversas, enquanto eu próprio sou justo e inocente do mal que me é feito (p. 21). 
Nesse sentido, os ressentimentos compartilhados com relação a Vargas foram um fator de agregação e de sentimento de solidariedade no interior do grupo armandista (ZIOLI, 2012). Apesar da união entre quase todos os exilados, Paulo Duarte selecionou apenas alguns do grupo como íntimos e solidários ao projeto comum de luta contra a ditadura: Armando de Salles Oliveira, Otávio Mangabeira, Luís Piza Sobrinho, Júlio de Mesquita Filho e Paulo Duarte formavam o seleto grupo dos amigos exilados. Além do café, o grupo mais intimo frequentava quase que diariamente o apartamento de Salles Oliveira em Paris, onde conversavam e decidiam as ações a serem tomadas. A ida para os Estados Unidos foi uma das decisões tomadas entre e pelo grupo.

Armando reuniu-se comigo e o Julinho em seu apartamento para combinar a nossa atitude. Parece que o melhor é irmo-nos preparando para a possibilidade de partir para os Estados Unidos. Ele conserva-se firme naquele plano de um navio com rádio a bordo. Mas se a guerra vier? Entretanto se a guerra nos pegar aqui ofereceremos os nossos serviços à França. Isso ficou bem resolvido em casa de Armando. Armando, Paulito, Mangabeira, Julinho e eu ficamos firmes nisso (DUARTE, 1977, p. 152).

A ida para os Estados Unidos já tinha como estratégia definida o encontro entre Armando de Salles Oliveira e o Secretário de Estado americano, Cordell Hull ${ }^{91}$. O objetivo do encontro era o de contestar publicamente a posição norte americana de apoio à ditadura Vargas. Ao mesmo tempo, e contraditoriamente, solicitava auxílio financeiro dos EUA para o plano do navio que traria a bordo os exilados, para, próximos da costa brasileira, fazer propaganda contrária ao governo Vargas. A confiança de que o encontro com Cordell Hull renderia bons frutos decorria das boas relações que Armando de Salles mantivera com aquele por ocasião de seu governo à frente do Estado de São Paulo. No relato de Paulo Duarte, em visita ao Brasil, Cordell Hull havia inclusive declarado que "o único chefe de governo de toda América Latina que o havia impressionado" (DUARTE, 1978, p. 172). Fora justamente o governador de São Paulo, elogiando principalmente traços de sua personalidade, determinado, arrojado e leal. Entretanto, o encontro foi mais uma decepção para os exilados, pois, ao invés da visibilidade pretendida, Salles Oliveira

\footnotetext{
${ }^{91}$ Cordell Hull foi um político e diplomata americano. Eleito Senador pelo Estado de Tenesse (1931-1937), abdicou do mandato para assumir o cargo de Secretário de Estado do governo Franklin D. Roosevelt. Foi ganhador do Premio Nobel da Paz, em 1945, devido sua participação na fundação das Nações Unidas. (In The Official Website of The Nobel Prize, acesso em 06/08/2015).
} 
foi recebido "criminosamente e com muita cautela diplomática" pelo referido secretário, ingressando no Departamento de Estado pela porta dos fundos.

Assim este estava estranhando a demora em ser atendido ou não o seu pedido de uma audiência. Armando tivera a precaução de deixar claro que ele poderia recebê-lo mesmo fora do Departamento de Estado, pois compreendia muito bem a situação. Até que enfim veio a resposta marcando o encontro em determinado dia, dando o telefone para onde deveria telefonar assim que chegasse a Washington para ser levado à presença do Ministro. Chegando pois à data marcada em Washington, Armando telefonou e um assistente de Hull foi imediatamente busca-lo à estação para a entrevista. Mas o assistente o fez entrar pelos fundos do ministério, entrada evidentemente sigilosa, o que levou o Armando a estranhar o ar de mistério que encontrou no Departamento de Estado. Foi levado a uma sala contígua ao gabinete, mas separada do corredor oficial que leva ao gabinete do ministro. Dez minutos depois veio o mesmo assessor e o conduziu a um pequeno particular, onde se achava Cordell Hull. Foi recebido cerimoniosamente e com muita cautela diplomática (DUARTE, 1978, p. 173-174).

Deixando de lado o constrangimento, Salles Oliveira expos a Cordell Hull a situação política brasileira e principalmente a situação dos exilados. Todavia, o golpe de Estado havia sido reconhecido pelo governo norte-americano em menos de 48 horas, diferentemente da situação dos revolucionários de 1932 quando estes pediram reconhecimento da beligerância de seu movimento e os Estados Unidos tornaram lentas as negociações. A explicação para o cauteloso e cerimonioso atendimento dado aos exilados pela autoridade norte americana ocorria em função dos outros interesses dos Estados Unidos no cenário internacional de deflagração da Segunda Guerra Mundial ${ }^{92}$. Buscava-se, diplomaticamente, reforçar as alianças e acordos com os governos dos países da América Latina, de modo a fortalecer a posição dos EUA na guerra. Segundo Duarte,

A opinião geral era que a ligação da América Latina com os Estados Unidos deveram ser mantidas num ambiente de amizade franca que não permitisse incertezas ou desconfianças, principalmente num momento como o de agora, quando a guerra começa já a arrastar todas as nações a tomarem uma direção, porque a neutralidade não seria possível de ser mantida seja lá porque governo fosse. E o atual governo do Brasil, com grandes afinidades com os totalitários, inclinava-se cada vez mais para as potencias do eixo e ainda agora acabavam de ser condecorados pela Alemanha, o Ministro da Guerra

\footnotetext{
92 Antes do início da Segunda Guerra Mundial na Europa, o Brasil manteve uma política de aproximação simultânea com os Estados Unidos e a Alemanha. Entretanto, com a evolução do conflito e devido ao esgotamento dos recursos brasileiros de barganha, o Brasil tornou-se cada vez mais comprometido com os norte-americanos e a entrada na guerra ao lado dos aliados (PINHEIRO, 1995).
} 
de Getúlio, o general Gaspar Dutra, e o chefe do Estado Maior das Forças Armadas, Góis Monteiro. Evidentemente o governo norte americano não podia ignorar isso, daí a perplexidade dos democratas brasileiros sentindo-se hostilizados pelos Estados Unidos, quando são eles os únicos contatos de amizade com que os povos livres poderiam contar na América Latina, onde a situação era mais ou menos a mesma (DUARTE, 1978, p. 173-174).

Assim, relembrando o encontro, Paulo Duarte procura amenizar o sentimento de fracasso e o clima de frieza e distanciamento que o caracterizaram, destacando a cordialidade de Salles Oliveira. Este líder, com seu poder de oratória, exercia fascínio em que o ouvia, até mesmo o experiente Cordell Hull. Com o sinal mais receptivo ao diálogo, o exilado pode expor francamente seu principal plano de oposição à ditadura.

[...] Armando contou a ideia dos democratas brasileiros, que estavam mais unidos do que parecia, de instalar uma estação emissora para de águas extraterritoriais levar ao Brasil a palavra dos homens livres e, ao mesmo tempo, revelar as ligações do seu governo com as potencias totalitárias contra todos os interesses americanos. Cordell Hull manifestou-se contrario à ideia, que podia criar dificuldades ao próprio governo dos Estados Unidos. O melhor seria esperar até o momento mais oportuno. Armando retrucou dizendo da sua surpresa, pois pensara até que a notícia poderia mesmo decidir da ajuda norteamericana na execução da ideia a ser realizada de maneira a não comprometer a cordialidade diplomática de qualquer país, pois entre os democratas brasileiros havia quem estivesse disposto a assumir a responsabilidade de tudo, sem comprometer ninguém, fosse lá quem fosse. [...] Cordell Hull foi muito amável, atencioso, mas deixou claro que os Estados Unidos não podiam arriscar-se a qualquer indiscrição que comprometesse o seu governo com relação à situação brasileira. [...] Pois ele fora para a entrevista crente até de que o próprio valor do pequeno vapor ou iate necessário ao nosso plano seria facilitado, com as cautelas necessárias evidentemente, pelo governo norteamericano (DUARTE, 1978, p. 174).

Falta de visão política, excesso de confiança, ingenuidade ou inexperiência do grupo, o certo é que a viagem fracassou quanto às suas pretensões maiores e menores, como o auxílio para o vapor. Salles Oliveira retornou para Nova York, convencido de que o grupo político nada podia esperar da democracia norteamericana. Assim como na Europa, a estadia nos Estados Unidos estava se revelando frustrante do ponto de vista de obter ajuda no combate à ditadura. $A$ força do governo de Vargas e a incapacidade do grupo armandista, pela sua fragilidade política, de combatê-lo ficavam cada vez mais evidentes. Para Paulo Duarte, apesar 
dos contratempos e da recepção pouco calorosa justamente da parte de quem o grupo mais esperava obter apoio, seria ainda possível a Armando de Salles ainda pudesse retornar ao Brasil e seguir seu destino político: o de presidir o país. "Não havia dúvida, o Armando poderia ser a salvação do Brasil. Havia arestas ainda a serem aparadas, mas tirados alguns carrapichos, a terra era boa e fértil" (DUARTE, 1978, p. 184). Tal projeção expressa a fidelidade quase canina de Duarte à pessoa de Salles Oliveira e ao projeto armandista, uma cegueira partidária que o impedia de ver, objetivamente, as reais condições de atuação do grupo e as reais possibilidades de retorno de Salles Oliveira à política.

\subsection{A aventura de Paulo Duarte, clandestino no Brasil}

Felizmente a carta original foi entregue por pessoa de confiança que esteve em Buenos Aires e a fez chegar as mãos do general Dutra que, pelo jeito, é também vigiado pela polícia. $\mathrm{E}$ o tonto não adere a mim para liquidarmos a ditatura! Ele é quem vai acabar sendo destruído (DUARTE, 1973, p. 22-23).

A citação acima se refere a mais um plano, talvez o mais ousado, elaborado por Duarte para combater a ditadura varguista. Desta vez, ele enfrentaria Vargas dentro do Brasil. Apesar das frustrações experimentadas nos Estados Unidos, como vimos anteriormente, foi lá que Paulo Duarte começou a elaborar o plano que considerava o mais ousado e perigoso contra a ditadura. Paulo Duarte tinha convicção de que, para combater Getúlio Vargas, era necessário arriscar-se e ir até as últimas consequências. O plano consistia em ir ao encontro do Ministro da Guerra, General Dutra, e propor-Ihe um golpe contra Getúlio Vargas. A escolha do General Dutra ${ }^{93}$, além de ser o Ministro da Guerra, se deu pela certeza do exilado de que seria bem recebido por aquele. Antes de partir para o exílio, quando Paulo Duarte sofreu várias prisões, tivera a oportunidade de conhecer o General Dutra. De acordo com Duarte, estabeleceram uma relação amistosa, sendo que Dutra chegou a garantir que Paulo Duarte não seria mais preso ou exilado. Na ocasião, discutiram

\footnotetext{
${ }^{93}$ Eurico Gaspar Dutra foi nomeado Ministro da Guerra do governo Getúlio Vargas em 1936, desempenhando papel fundamental juntamente com Vargas e Goés Monteiro no fechamento do regime democrático e instalação do Estado Novo.
} 
política, cultura e os rumos do regime ditatorial no Brasil. Em sua avaliação, caso o General Dutra no último momento recuasse e não apoiasse a proposta de aliança com o grupo armandista para realizar um golpe para depor Getúlio Vargas, também não criaria maiores problemas. Seguramente, em caso de derrota, permitiria que Paulo Duarte deixasse o Brasil e retornasse para o exílio.

Paulo Duarte tinha tentado estabelecer contato com o General Dutra desde o exílio. Algumas cartas foram enviadas a ele, mas não obtiveram resposta, posição que, no entanto, Duarte compreendia em razão da condição de Ministro da Guerra:

\begin{abstract}
Uma ideia, desde Paris, anda me saracoteando no espírito. Possuo uma documentação esplêndida sobre os riscos que correm os países da América do Sul, principalmente o Brasil, neste momento angustioso de ameaças imperialistas e outras tão execráveis como a primeira. O General Dutra não responde às cartas que lhe tenho enviado. Compreendo isso principalmente pelos riscos que qualquer documento dele oferecia à sua pessoa e também porque ele me parece indeciso diante de certas atitudes. Penso assim ir pessoalmente animá-lo e empurrá-lo para a frente talvez, levando-lhe esses documentos (DUARTE, 1978, p. 206).
\end{abstract}

Paulo Duarte, numa atitude de muita presunção e pouco realismo, avaliava que o General Dutra não estava de acordo com a ditadura varguista e que haviam desentendimentos entre o Ministro da Guerra e Getúlio Vargas. Desde o levante integralista de maio de 1938, boatos a respeito da fidelidade do General Dutra a Vargas circulavam. No episódio do assalto ao Palácio da Guanabara, a demora em combater os invasores gerou suposições sobre a conivência tanto de Dutra como de Góes Monteiro com o levante. Alzira Alves Abreu, ao escrever a biografia do pai, acusou o General Dutra de traição. Causou estranheza a Alzira o fato de que, em meio aos disparos de metralhadoras pelos integralistas, Dutra teria entrado e saído do Palácio da Guanabara sem se ferir gravemente, apenas com escoriações na orelha. Alzira retratou a atitude do Ministro da Guerra naquele levante como "estranhamente alheio aos acontecimentos" (ABREU, apud HORNOS, 2008, p. 140).

Razões parecia ter Paulo Duarte para pensar que o General Dutra talvez fosse a pessoa mais indicada para se estabelecer contato e planejar o golpe. Ainda em Paris, Paulo Duarte procurou Armando de Salles Oliveira para expor sua ideia, "que ficou um pouco surpreendido com o que lhe propus, isto é, a minha entrada clandestina no Brasil e procurar o próprio Ministro da Guerra. Depois fez-se silêncio 
sobre o assunto até a nossa vinda pra cá". Ao retomar o assunto, agora exilados nos Estados Unidos, Paulo Duarte teve sua primeira grande decepção com a postura nada revolucionária de Armando de Salles Oliveira, que não apoiava aquele plano, sequer pensava ser ele crível. Se Paulo Duarte demonstrava ter uma visão política míope, ou romantizada quanto às possibilidades de realizar um golpe contra Vargas, agindo sem medir as consequências, Salles Oliveira, ao contrário, mantinha uma postura pragmática.

O Armando preocupou-se com o projeto, me falou dos riscos, lembrou que eu não podia ter confiança no Dutra pois, Ministro da Guerra, se sentiria, com a primariedade dos militares, no dever de me prender e me denunciar. Eu tinha alguma confiança no General Dutra, mas admitia a hipótese de minha prisão, isso porém é pormenor que não me intimida. Por fim Armando me decepcionou quando, afinal, disse que ele não assumiria a responsabilidade dessa missão. Me ajudaria em tudo, mas excluindo essa responsabilidade, pois se acontecesse alguma coisa irremediável ele não queria ser acusado pela minha família. Lembrei-me de Victor Serge quando me falou que os meus companheiros principais não eram chefes revolucionários, pois um revolucionário não pode pensar em família, nem num filho para prosseguir na ação. (DUARTE, 1978, p. 206).

Vale a pena comentar esse encontro de Paulo Duarte com Victor Serge, pois as posições políticas deste abalaram profundamente a imagem que o exilado fazia de si mesmo e de seus companheiros de luta e exílio, de uma tomada de consciência quanto a ser "revolucionário". Victor Serge, nascido em Bruxelas como Victor Lvovitch Kibaltchitch, em 1890, filho de pais russos, refugiados políticos, estava residindo em Paris quando conheceu o grupo de exilados brasileiros. Paulo Duarte não descreve como se deu o encontro, talvez mediado pelo amigo Claude Lévi Strauss, a quem Serge havia conhecido na mesma época (RENTON, 2007). De acordo com o memorialista, Serge era defensor de um socialismo puro e havia travado luta contra Josef Stálin, tendo sido já enviado para uma prisão na Sibéria e posteriormente expulso da URSS. A conversa entre os dois exilados fez Paulo Duarte reavaliar a posição política-ideológica de seu grupo que, segundo Serge, não "era revolucionário":

Este não é revolucionário. Perguntara a Julinho porque não organizávamos uma contestação mais forte à "bande" de Vargas, mas com uma campanha violenta no estrangeiro, Julinho lhe respondera porque isso poderia provocar represálias no Brasil contra as nossas famílias que lá ficaram, daí os cuidados que precisávamos ter. Se fosse revolucionário, a família estaria completamente alheia a 
essa ação, "mas quem tem medo de ver a família atingida não é revolucionário." E ele tinha autoridade para dizê-lo, o filho fora morto na Rússia por causa da ação dele contra Stalin (DUARTE, 1977, p. 154).

Julinho de Mesquita e Salles Oliveira sequer mencionaram que haviam se encontrado com Victor Serge e tido a conversa citada acima, o que deixou Paulo Duarte ainda mais inquieto e mesmo ressentido. Passou então a questionar se Armando de Salles Oliveira estava mesmo disposto a levar adiante a luta contra Getúlio Vargas, enfrentando o que fosse necessário, pagando o preço que fosse preciso pagar. O plano de lutar contra o Estado Novo a partir da costa brasileira pareceu-Ihe então ameaçado:

[...] eu custei a dormir, pensando sempre em Victor Serge. E voltei a perder o sono depois, quando pensei no que Julinho dissera a Victor Serge. E Serge a mim: "Seus companheiros não são revolucionários, são apenas bons pais de família. E isso não basta". E o resto da noite não pude mais dormir com medo dos meus companheiros (DUARTE, 1977, p. 155).

Até aquele momento, Paulo Duarte tinha uma visão liberal do que era "ser revolucionário", onde as mudanças deveriam correr via reformas levadas a cabo pelo Estado e amparadas na Constituição. As palavras de Victor Serge passaram, porém, a fazer sentido para Paulo Duarte, quando Salles Oliveira recusou o envolvimento direto com o plano de um golpe contra Vargas, entrando clandestinamente no Brasil e buscando o apoio de Dutra, Ministro da Guerra de Vargas, temeroso das "represálias" no Brasil contra suas famílias que lá ficaram e sobretudo com o envolvimento com um golpe. Ao contrário de Serge, que era um verdadeiro revolucionário, pois não cedia às ameaças de execução de seu filho, por parte do governo de Stálin, para desistir de lutar contra o stalinismo. Ao contrário, Serge intensificou sua luta e por isso seu filho fora assassinado, inversamente ao ocorrido com Salles que, no exílio, foi esmorecendo, fraquejando em sua luta contra a ditadura de Vargas:

Agora, Armando me nega solidariedade numa missão que não é minha pessoal, é nossa, principalmente dele que é o chefe supremo de qualquer ação. Ele mesmo trazia na cabeça o projeto de uma estação transmissora para falar para o Brasil, fora das águas brasileiras e eu seria o chefe dessa missão. E não foi até agora por diante porque não encontrou o necessário apoio nem na França nem 
aqui. Insisti, mas ele ficou irredutível, carinhosamente irredutível, mas eu substituo o adverbio irredutível por fraqueza como chefe (DUARTE, 1977, p. 206).

Com efeito, Salles Oliveira não cedeu aos apelos de Paulo Duarte e exigiu que seu nome não fosse envolvido na missão, vista por ele como temerária. Entretanto, ficou combinado que ele, secretamente, forneceria todos os recursos financeiros necessários à realização da mesma. Também foi acordado que, caso a missão falhasse e Paulo Duarte fosse preso ou até mesmo fuzilado, este deveria escrever uma carta esclarecedora, retirando toda e qualquer responsabilidade de Armando de Salles Oliveira, "o chefe supremo de qualquer ação". Antes de partir, Paulo Duarte redige então uma carta endereçada ao amigo e líder, expondo seu plano, seus objetivos e estratégias de luta. Antes disso, assumia a total responsabilidade pela missão e suas possíveis consequências:

Minha ideia é a de entrar no Brasil clandestinamente, dirigir-me logo após à presença do General Dutra e pôr-me à sua disposição para luta que, segundo todos os sintomas, esta prestes a decidir-se entre o Ministro da Guerra e o ditador. Justifico o meu gesto com uma dedução baseada exclusivamente em motivo pessoal. Conheço, há pouco, em verdade, o general Dutra. Vi-o apenas duas vezes. Tão especiais foram porém esses encontros que pude fazer um juízo que reputo seguro, a respeito da personalidade do Ministro da Guerra do Brasil. Quando a ele me apresentei pela primeira vez, não esqueci um só momento que me achava em frente da maior garantia que teve o ditador para dar o golpe de 1937. E, quando o deixei pela segunda e última vez, levava a convicção de tratar-se de um homem que tinha profundo amor ao Brasil e que, como tantos outros, inclusive nós mesmos em 1930 e 1934, tivera sido ludibriado pelo sr. Getúlio Vargas. [...] E a mim me parece que não seria de todo inútil um contato com o General Dutra. Só os homens de má fé ou cegos seriam capazes de negar nossa significação política no Brasil. ${ }^{94}$

Mais uma vez, num exercício meio quixotesco acerca da avaliação que faz de si, de sua significação política no Brasil, Duarte se reconhece como um dos últimos paladinos que, isoladamente, da lutou contra a ditadura varguista, permaneceu fiel ao projeto político de luta. Com os objetivos expostos acima, Paulo Duarte seguiu clandestinamente para o Brasil, embarcado no vapor Delmundo, para descer no Rio de Janeiro no dia 19 de julho de 1939 e ir ao encontro do General Dutra. Com o nome de P.A.J. Monteiro em seu passaporte, Paulo Duarte deixou

\footnotetext{
${ }^{94}$ Carta de Paulo Duarte para Armando de Salles Oliveira. New York, 10 de junho de 1939. In DUARTE, 1978, p. 210-11. Uma cópia da carta encontra-se no Arquivo Paulo Duarte (PD/ASO, p. 37).
} 
crescer o cabelo, bigode, comprou óculos e roupas americanas, tudo diferente do que estava habituado a vestir. "Assim, penso que entrarei no Rio, sem ser descoberto. A tentativa não tem meio termo: ou ganhamos a partida ou irei para Fernando de Noronha se não acontecer coisa pior" (DUARTE, 1978, p. 227).

Paulo Duarte, como esperava, foi bem recebido pelo Ministro da Guerra e conversaram longamente. No entanto, Dutra não lhe deu qualquer sinal de quando à possibilidade de colaborar com a ação do grupo armandista. Embora tenha recebido os documentos que depunham contra o governo Vargas, o Ministro aconselhou que o exilado deixasse o Brasil imediatamente. Paulo Duarte, sentindo que sua missão estava cumprida, pois afinal ao menos Dutra recebeu a referida documentação, seguiu o seu conselho. No porto de Santos o exilado quase foi reconhecido pelas autoridades; todavia, foi defendido pelo chefe da polícia marítima e apoiado pela população do vapor Delmundo (DUARTE, 1978, p. 240). Getúlio Vargas teria ficado sabendo da visita do exilado e ordenou que a polícia política o prendesse. A ação da ditadura foi frustrada devido à defesa do chefe da polícia marinha, que era paulista, e não quis submeter-se à polícia do Distrito Federal. Nada, porém, passou desapercebido no governo Vargas, já que este registrou a ação do exilado em seu diário, no dia 21 de julho de 1939:

Fui informado pelo Chefe de Polícia que o exilado Paulo Duarte fora recebido pelo Ministro da Guerra, a quem entregara uma carta do Armando de Salles Oliveira convidando-o a me depor antes que eu o exonerasse. Que reles intrigante! (VARGAS, 1995, p. 33).

De "revolucionário" a "reles intrigante", o percurso político de Paulo Duarte parecia ter seus dias contados. Em seus registros memorialísticos é possível perceber seu esforço em separar suas memórias pessoais, perpassadas pelos ditames da emoção e dos sentimentos, das memórias políticas, que foram selecionadas a partir de uma vasta documentação, cuidadosamente guardada, sem qualquer comentário de quem a selecionou. Quem fará isso, na intenção de quem organiza, é o historiador, aquele que registrará sua presença na história, seu legado político para a história do país. A documentação pessoal e pública organizada tem como eixo central, aglutinada a tradição política de Vargas. Como ressalta Sandes, a política de Getúlio Vargas é evento central, eixo ordenador das lembranças, atravessadas pelo ressentimento (SANDES, 2011). Pierre Ansart, ao pensar as 
relações tecidas entre história, memória e ressentimento, coloca importante questão: "que memória conserva um grupo de seus próprios ressentimentos e dos ressentimentos dos inimigos dos quais foi vítima?" (2004, p. 30). No caso de Paulo Duarte, a aversão ao getulismo permeara sua narrativa ao longo dos nove tomos na qual ele ocupa posição de centralidade. Todavia, no pesado jogo político nacional, as ideias e ações de Paulo Duarte passam quase desapercebidos: Getúlio Vargas destinou pouca atenção ao exilado. Ao consultar o índice biográfico do diário de Vargas, podemos constatar apenas duas citações referentes a Paulo Duarte, uma delas é exposta acima, feita por ocasião da visita clandestina do exilado ao Brasil. $O$ memorialista é nomeado por Vargas como um "reles intrigante", coadjuvante político sem importância, cujo destino é o esquecimento, destino que Paulo Duarte buscou evitar com suas memórias. Compreensivamente, o líder Salles Oliveira mereceu significativo destaque nos registro de Getúlio Vargas, sendo citado 44 vezes entre 1930 e 1945. Sua posição de centralidade na política paulista de oposição a Vargas evidencia-se no quantitativo dessas referências. Ele não merecia o esquecimento; sua obra política e cultural cuidou de lembrar sua presença na história.

\subsection{Paulo Duarte, memória e ressentimento}

Depreendemos das Memórias de Paulo Duarte alguns ressentimentos, derivados da frustração que ele sentia quanto ao que projetara para si na política nacional, ao que reconhecia ter feito nesse sentido e ao que foi reconhecido por $\mathrm{e}$ entre seus pares, os políticos de sua época. Um dos maiores ressentimentos era em relação a Getúlio Vargas, acusado por ele de traidor nos movimentos de 1930, 1934, ao golpe de novembro de 1937. Havia também o ressentimento com Vargas pelos dois exílios vivenciados e considerados por Duarte descabidos. A ausência forçada por meio do exílio representou um sentimento ambíguo para Paulo Duarte. Se a condição de exilado significou um certo prestígio, pois transformado em perseguido pela ditadura Vargas, e também aumentou sua rede de sociabilidade, inserindo-se em novos círculos intelectuais e culturais, algo extremamente valorizado por ele, por outro lado, significou também o distanciamento. Não apenas 
de seu país, de seus familiares e de Juanita, sua mulher, ${ }^{95}$ mas do cenário político nacional, dos debates, das ações. Não por acaso, Duarte se sentia dividido e frustrado. Ele se contradiz, pois, apesar de se julgar um revolucionário, capaz dos maiores sacrifícios até mesmo mais do que seus companheiros de exílio, lamentava porém ter deixado seus familiares, por conta do exílio. O exílio implicou sua ausência no enterro do pai, falecido em 1943, e cujo ultimo contato tinha sido no porto de Santos, antes de partir para seu segundo exílio. Ausência também por ocasião da morte de importantes companheiros, como Armando de Salles Oliveira e Mário de Andrade ${ }^{96}$, ambos falecidos em 1945. De acordo com Paulo Duarte, o exílio fazia com que até mesmo os homens fortes, certamente como ele, desabassem. Nesse sentido, também o outro ressentimento com o esmorecimento das posições dos principais chefes armandistas que se diziam "revolucionários", mas que se transformaram em pessoas fragilizadas, reduzidas a "bons pais de família", por conta da condição de exilados. Com efeito, quando de seu primeiro exílio, resultado do envolvimento na Revolução Constitucionalista de 1932, Paulo Duarte relata algo que sucedeu com o chefe do PRP, Altino Arantes. Estavam ambos no mesmo navio, com destino à Europa e ao exílio forçado, quando Altino Arantes, visivelmente abalado, diz: “- Veja, uma gaivota! Ela está livre!” E cai em prantos (DUARTE, 1977, p. 111). Se o exílio representou algumas oportunidades para Paulo Duarte, dentre elas, a de finalmente conhecer a Europa e os Estados Unidos, a de ampliar sua rede de sociabilidade e de contatos, a de construir a imagem de paladino perseguido, representou também humilhações e privações. A principal delas, a liberdade de ir e vir, e ainda as dificuldades de sobreviver no dia-a-dia, devido à sua precária situação financeira. Em meio a tais experiências engendramse o sentimento de ressentimento a Getúlio Vargas e todo seu governo, ao exílio, aos companheiros que recuaram, a Salles Oliveira pelo seu recuo e/ou pragmatismo político.

\footnotetext{
${ }^{95}$ Quando Juanita quis ir ao encontro de Paulo Duarte durante seu exílio em Buenos Aires, este não pode permitir, uma vez que sua situação financeira era precária. Diferente de seus companheiros de exílio, que puderam receber suas esposas e família, como Armando de Salles Oliveira e Júlio de Mesquita Filho.

${ }^{96}$ Mário de Andrade foi grande amigo de Paulo Duarte. Por indicação e insistência deste, Mário de Andrade foi diretor do Departamento de Cultura, um dos grandes projetos de Paulo Duarte quando da sua função de chefe de gabinete do Prefeito Fábio Prado (1934-1938). Em 1971, Paulo Duarte publicou Mário de Andrade por ele mesmo, onde estão as cópias de cartas trocadas entre os dois. (BOMENY, Helena. Um poeta na política. Mário de Andrade, paixão e compromisso. Casa da palavra, 2012).
} 
Marcos Zioli, em tese de doutorado, analisou a obra memorialística e literária de Paulo Duarte. Para tal, ele considerou também algumas produções memorialísticas de seus contemporâneos, a fim de perceber as diferenças entre o posicionamento político de Paulo Duarte e o de vários intelectuais de sua época, cooptados ou não pelo governo Vargas. De acordo com a avaliação daquele historiador:

Para os contemporâneos de Paulo Duarte, os fatos políticos mais significativos foram as tentativas de ruptura ou as rupturas institucionais que se materializaram representadas pelos movimentos armados de 1924, 1930 ou 1932 e pela relação de apoio ou oposição ao longo governo de Getúlio Vargas, entre 1930 e 1945. Foi em torno desses fatos políticos que esses intelectuais se posicionaram na tentativa de convencer seus leitores de que as escolhas e os caminhos seguidos teriam sido, senão os melhores, ao menos os possíveis (ZIOLI, 2012, p. 112).

Diferente de seus contemporâneos, não nos parece que Paulo Duarte tenha tentado convencer seus leitores de que as opções feitas foram as melhores ou as possíveis, já que o esforço em buscar um culpado é recorrente em seu texto. E o culpado é sempre Vargas e seu projeto continuísta. Na avaliação de Paulo Duarte, o projeto político paulista foi bruscamente interrompido pelo golpe do Estado Novo e a retomada de sua execução, juntamente com a retomada do poder por parte do grupo armandista, não foi possível devido ao desempenho insatisfatório, tíbio, moderado, de seus companheiros de exílio e luta. A princípio, Paulo Duarte estava convencido de que o grupo iria até às ultimas consequências para retomar o governo de São Paulo e dali projetá-lo para o Brasil. Nesse caso, o exílio seria apenas um desvio forçado ou um momento de pausa para redobrar as forças, como ele mesmo assinalou: "a ditadura deu-nos o exílio com o intuito de fazer dele a nossa sepultura, mas nós fizemos dele a nossa tribuna" (DUARTE, 1977, p. 140). Entretanto, à medida em que as estratégias de luta não obtiveram o resultado esperado, em que seus companheiros começam a fraquejar, a ponderar prós e contras, ele foi ficando só, lutando "contra moinhos". Quando finalmente percebe essa situação, toma consciência da inviabilidade de continuar sua luta contra a ditadura Vargas, ele desiste da luta. Abandona a política, o grupo armandista e parte de novo para Europa, agora como correspondente de Guerra. 
Como já mencionamos, um ressentimento que ganhou destaque na narrativa memorialística de Duarte é com seus companheiros de luta e exílio. Desde a recusa de Armando de Salles Oliveira em se envolver diretamente com a viagem clandestina ao Brasil, Paulo Duarte começou a alimentar desconfiança pelo companheiro, não pelo seu caráter, mas por sua recusa em agir, aderindo ao seu plano de luta. A decisão última de se afastar do grupo político e seguir para a Europa na condição de correspondente de Guerra foi por certo enfrentada pela sua avaliação quanto a conduta de Salles Oliveira, um "grande chefe" para "tempos de paz e construção", mas não um "chefe revolucionário":

Depois eu já me convenci de que o Armando é um grande chefe, eficiente, lúcido, altamente capaz, mas um chefe para tempos de paz e construção, não é um chefe revolucionário, como bem notou Victor Serge, em ação revolucionária ele avança até certo ponto, mas detém-se quando as dificuldades são enormes. A atitude dele comigo o demonstra. Dentro das circunstancias atuais ele é uma grande reserva e a sua oportunidade não chegou ainda. Precisa ser preservado, mas necessita neste momento crítico da luta, de alguém que pense e resolva mais alto e mais violentamente, revolucionariamente, mas quem dos nossos companheiros seria capaz? Nenhum, só eu o seria se tivesse à minha disposição dinheiro suficiente a garantir a ação e isso ninguém me dará. Os revolucionários quando precisam de dinheiro, eles mesmos têm que arranjar porque os homens de dinheiro não ajudam os mais amalucados e não se convencem de que eles serão os primeiros a serem esmagados por certos acontecimentos. $\mathrm{E}$ a oportunidade pode passar sem que nada realizemos (DUARTE, 1978, p. 24).

A questão financeira foi por certo um dos pontos de atrito, de desentendimento entre Paulo Duarte e Salles Oliveira. Quando retornou da viagem clandestina ao Brasil, Paulo Duarte ficou em Buenos Aires, justamente por não ter condições financeiras de arcar com uma passagem de volta para os Estados Unidos. O acordo era que Salles Oliveira cobrisse todas as despesas da missão, incluindo garantir o retorno de Paulo Duarte àquele país. Entretanto, quando Paulo Duarte cobrou o combinado, Salles Oliveira se absteve, alegando estar em situação financeira instável. Convencido de que teria que permanecer em Buenos Aires, Paulo Duarte pediu a Salles Oliveira que enviasse à capital argentina seus pertences, incluindo seu arquivo político e biblioteca, instrumentos de trabalho considerados essenciais ao exilado. Também nesse caso, Armando de Salles se 
recusou a colaborar, alegando que o envio de toda bagagem ficaria extremamente caro e ele já não dispunha da mesma folga financeira de outros tempos. Júlio de Mesquita Filho também não se dispôs a colaborar. Paulo Duarte se sentiu abandonado e profundamente humilhado e magoado. Percebeu, finalmente, que apesar de serem grandes políticos e homens de extrema inteligência, Armando de Salles Oliveira e Júlio de Mesquita Filho não passavam de homens ricos, incapazes de compreender a miséria humana. ${ }^{97}$

A relação entre Armando de Salles Oliveira e Paulo Duarte nunca foi tranquila, mas tensionada pela desconfiança e provavelmente pela disputa, pela diferença de classe, de visões da política e do mundo. Apesar de terem pontos de aproximação, traduzido em projeto político em comum e de um mesmo objetivo, o de combater a ditadura varguista, a maneira de agir de um e de outro os distanciava. Salles Oliveira, liberal, priorizava a política como arte de transigir, negociar, acordar, haja vista seu pragmatismo de se aproximar de Vargas sob o argumento da "política como arte de esquecer". Já Paulo Duarte era um político radical, embalado pelo ideário revolucionário que formou o pensamento e ação de muitos jovens de sya época, geração dos anos 1920-1945. Como tal, não transigia, sentia necessidade de se portar como revolucionário, que morreria pela causa se fosse necessário, sem fazer acordos, sem negociar. Nesse sentido, Duarte atribuía exclusivamente a Armando de Salles Oliveira suas decepções com a aliança política estabelecida com Getúlio Vargas, entre 1933-1936. Em 1933, assim que retornou do primeiro exílio, Paulo Duarte chegou até mesmo a desconfiar das intenções de Salles Oliveira. Este, ao ascender à interventoria de São Paulo, na avaliação de Duarte, teria pago um alto preço pelo cargo, um deles o de se deixar seduzir por posições de mando e se aliar a Vargas, fazendo concessões quanto ao projeto político do grupo. ${ }^{98}$

\footnotetext{
${ }^{97}$ Este episódio está narrado no volume 7 das memórias de Paulo Duarte, Miséria Universal, Miséria Nacional e minha própria Miséria, 1978.

${ }_{98}^{9}$ Nos volumes III e IV de suas memórias, Selva Oscura e Os mortos de seabrook, respectivamente, Paulo Duarte rememora o retorno de seu primeiro exílio, junto a Júlio de Mesquita Filho. Ao chegar ao Brasil, Paulo Duarte teve receio de que Armando de Salles Oliveira tivesse aderido por completo o governo ditatorial de Getúlio Vargas, esquecendo, portanto, dos planos de um projeto político para o Brasil. Armando de Salles Oliveira precisou convencê-lo de que não era o momento de uma nova revolução, só assim os paulistas teriam uma chance de alcançar o governo e realizar seu projeto. As armas precisavam ser trocadas pelas urnas, e assim foi feito. Estes episódios e os que dizem respeito à atuação de Armando de Salles Oliveira enquanto interventor foram abordados em minha dissertação de mestrado, Política: a arte de lembrar e de esquecer. UnB, 2012.
} 
Ao contrário de Armando de Salles Oliveira e de vários de seus partidários, Paulo Duarte, em nenhum dos momentos de aproximação entre o grupo político armandista e Getúlio Vargas, mudou sua opinião negativa a respeito daquele. As referências a Getúlio Vargas em suas memórias serão sempre marcadas pela oposição explícita e pela crítica severa. Descumpridas as promessas da Revolução de 1930 e, posteriormente, de 1934, Paulo Duarte se transformou em sistemático e contundente crítico do governo Vargas que ele considerava ditatorial. $O$ "revolucionário" poderia ter construído sua vida pública à sombra do novo regime, instalados nos órgãos governantes, como fizeram vários políticos modernistas do seu tempo, sobretudo após o Estado Novo. Todavia, escolheu ser coerente com seus princípios e ideais, travando ferrenha oposição aberta e pública a Vargas. Enfrentou, por isso, dois exílios, entre 1930 e 1945 (ZIOLI, 2010). Embora sem transigir quanto aos princípios, fez algumas concessões. Uma delas, a de controlar seu ímpeto crítico e de oposição a Vargas durante o período em que Armando de Salles Oliveira e os constitucionalistas estiveram no poder. Essa concessão foi feita em nome da sustentabilidade política ao governo do interventor e, sobretudo, das possibilidades de tornar o projeto político do grupo uma realidade. Afinal, pragmaticamente, não havia nesse momento e contexto, motivos para confrontar diretamente Getúlio Vargas, uma vez que entre 1933 e o início de 1937, o momento foi de composição com o governo central que nomeou Armando de Salles Oliveira interventor de São Paulo. Entretanto, na avaliação de Duarte, com o golpe do Estado Novo, apesar das conquistas adquiridas enquanto o grupo armandista esteve à frente do governo paulista, havia um erro nessa aliança espúria. O erro em estabelecer uma aliança com o indecifrável Getúlio Vargas, alguém em quem Paulo Duarte jamais confiou. E ele teve mostras suficientes para isso, ao longo de toda a era Vargas.

Por fim, voltamos à questão colocada no início deste capítulo: por que Paulo Duarte narrou detalhadamente suas memórias e se dispôs a reunir e organizar um arquivo político daqueles conturbados anos? Constituir um arquivo e escrever uma narrativa memorialística, no caso de Paulo Duarte, estaria diretamente ligado ao sentimento de ressentimento em relação ao seu passado político, experiências em que ele se reconhece como "derrotado" e sobretudo como um injustiçado na política nacional durante a era Vargas. Como bem assinala Peter Burke: 
Diz-se muitas vezes que a história é escrita pelos vencedores. Poderia também dizer-se que a história é esquecida pelos vencedores. Podem permitir-se esquecer, enquanto os derrotados são incapazes de aceitar os acontecimentos e estão condenados a meditar sobre eles, a revivê-los e a imaginar quão diferentes poderiam ter sido (BURKE, 1992, p. 246).

Mesmo estando figura presente em momentos marcantes da história de São Paulo, ao lado de sua elite intelectual e política, "Paulo Duarte sempre apareceu em segundo plano, como primo pobre desta elite." 99 Significativamente, experimentou grande mágoa, inclusive de Armando de Salles Oliveira, seu "chefe supremo" e de Júlio Mesquita Filho, o amigo Julinho, companheiro do mesmo projeto político. Essa efetiva posição secundária no grupo armandista, jamais reconhecida por ele, revelase nas raras referências à sua pessoa no diário de Vargas. Revela-se também na recusa de Salles Oliveira e outros chefes do grupo armandista em apoiar seu projetado golpe contra o governo Vargas, com o apoio de Dutra. Revela-se ainda na omissão de seu nome entre os fundadores da Universidade de São Paulo. No arquivo construído, Paulo Duarte procurou suprir essa omissão, romper esse silêncio construído na/pela memória e história daqueles eventos, ao ressaltar que participou ativamente das decisões cruciais para a criação da USP, indicando, incusive, importantes nomes estrangeiros que comporiam o quadro da universidade. "Revelase no ressentimento de Paulo Duarte, em sua" incapacidade de "aceitar os acontecimentos", em sua insistência em "revivê-los" e a imaginar quão diferentes poderiam ter sido". Ressentimento esse que é tão interessante quanto os inúmeros personagens e episódios que ele apresenta em sua narrativa memorialística. Ressentimento que, segundo Pierre Ansart, é "reforçado pelo desejo de reencontrar a autoridade perdida e vingar a humilhação experimentada" (ANSART, 2004, p. 19).

A "humilhação experiementada" pela falta de reconhecimento público de seu mérito político, de suas contribuições à causa política paulista, é assim atenuada nesse exercício de rememoração em que ele ocupa finalmente a posição de centralidade. Como autor, sujeito de suas memórias, de seu espaço de fala e de lugar de sujeito, Paulo Duarte retira do silêncio inúmeras vozes, sobretudo a sua, excluídas do discurso historiográfico sobre a Era Vargas. Promove um deslocamento

\footnotetext{
99 SUgIMOTO, Luís. A saga de Paulo Duarte, combativo e combatido, nas 60 mil peças de seu acervo na Unicamp. In Jornal da Unicamp, Edição 209, 7 a 21 de abril de 2003. Acesso em 05 de setembro de 2015.
} 
de posições, deixando a de coadjuvante para ocupar a de protagonista. Ao mesmo tempo, ele constrói a sua verdade acerca da experiência política vivenciada por ele enquanto integrante do grupo armandista, derrotado no jogo político nacional, mas vitoriosa como uma memória de oposição e de resistência à ditadura que não se perdeu nos labirintos do tempo. Ele constrói uma memória acerca dessa experiência em seu nome e em nome do grupo político do qual fazia parte e com o qual se identificava e que a história se incumbira de fazer justiça do seu legado. Grupo político reconhecido por seus integrantes, não sem presunção, como único habilitado para enfrentar a ditadura Vargas e conduzir o país nos rumos democráticos, sob a liderança de São Paulo, "a vitrine do Brasil."

Segundo Noé Sandes (2009), tanto Paulo Duarte como Armando de Salles Oliveira assumem uma posição romântica na narrativa memorialística daquele exrevolucionário: a de opositores do governo ditatorial que Vargas conseguira instaurar no país, uma posição de oposição sem qualquer resultado efetivo diante da composição das forças civis e militares em torno do governo Vargas. Uma luta inglória, à distancia, sem maiores ressonâncias junto à sociedade civil, às forças políticas amordaçadas e/ou cooptadas pelo governo do Estado Novo durante mais de oito anos de "escuridão política, moral e mental". Como ressalta Sandes:

Com o registro de suas memórias, Paulo Duarte retirou do silêncio inúmeras vozes. Sua versão dos acontecimentos esteve sempre acompanhada de cartas, muitas cartas, fotos, muitas fotos e um relato minucioso dos fatos, indícios de que percorrera sua memória e seu arquivo em busca da verdade de sua atribulada vida (SANDES, 2011, p.15).

É possível apreender de suas memórias que Paulo Duarte não se considerava jamais um "reles intrigante", mas um paladino da democracia. O arquivo e os nove tomos de memórias são a prova material e documental de que o exrevolucionário protagonizou a história política do país nas décadas de 1930-1940. Arquivo, memória e história trabalham em conjunto, ancorando a expectativa de Paulo Duarte de ser lembrado como opositor de Getúlio Vargas, como um sujeito político e histórico, como integrante da elite política paulista e nacional.

Como sublinha Noé Sandes, "as memórias de Paulo Duarte representam expressivo empreendimento memorialístico sobre os acontecimentos que marcaram a fase de ostracismo de parte da elite paulista no mundo político" (SANDES, 2011). Se Vargas não destacou a atuação de Paulo Duarte, referindo-se a ele tão somente 
um "reles intrigante", o arquivo deixado e a extensa narrativa memorialística trabalham juntos para operar sua visibilidade pública e política, isto é, histórica, na posição de membro ativo de um grupo político que, embora derrotado, incomodou o governo varguista, combateu-o constantemente, direta e indiretamente.

Com efeito, nas memórias desse exilado, é possível perceber o tenso diálogo entre memória e história na busca de um sentido de orientação e localização em seu presente. Como combatente, combatido, derrotado, Paulo Duarte buscava, nesse exercício de construção de uma memória, fazer uma autocrítica da atuação de seu grupo. Daí o esforço dele em reviver o acontecido e as estratégias de luta no afã de identificar falhas, desvios e responsáveis. Nesse exercício, ele projeta-se na centralidade dos eventos e projeta um futuro que poderia ter sido diferente, se suas propostas tivessem sido consideradas, aprovadas e executadas pelo grupo. 


\section{CONSIDERAÇÕES FINAIS}

Longe de ser o resultado lógico da Revolução de 1930, o golpe de novembro de 1937 foi o desfecho de jogos políticos, confrontos e entendimentos travados principalmente entre os anos de 1933 e 1937. Nesse sentido, procuramos demonstrar, no presente trabalho, como que a atuação tanto do grupo político de Armando de Salles Oliveira como a de Getúlio Vargas foi sendo pensada e experimentada na luta acirrada pelo controle do poder. Consideramos que o sucesso ou fracasso dos projetos políticos apresentados naquele período foram historiograficamente construídos. Getúlio Vargas ainda é reconhecido, e com razão, por sua grande capacidade de articulação política. Além disso, ele também foi representado, até mesmo pela imprensa daquele período, como hábil manipulador, enquanto os grupos que negociaram ou disputaram com ele eram vistos e considerados como políticos ingênuos, como no caso dos armandistas e seu líder, Armando de Salles Oliveira. Procuramos desconstruir e desnaturalizar tal construção, ao demonstrar que o grupo político armandista também foi eficaz em articular alianças em meio ao intrincado jogo político da década de 1930, negociando sua participação política segundo as possibilidades do momento e projeções para o futuro político de São Paulo e do país. Em razão do projeto político dos armandistas, por mais de uma vez, o presente exigiu que este grupo negociasse com Getúlio Vargas. A historiografia tradicional subestimou a ação deste grupo político, ao identificar que seu interesse maior em tal aproximação fosse apenas o de manter cargos de poder.

O debate sucessório de 1936-1937 foi o momento de afastamento definitivo entre Getúlio Vargas e os armandistas. No caso de Vargas, a possibilidade de evitar que a sucessão presidencial acontecesse, e assim poder continuar no poder, começou a ser desenhada e articulada a partir das oportunidades que surgiram com o conturbado quadro político do período pós-1934. Nesse sentido, destacamos que a ameaça comunista, suposta ou real, foi um elemento importante para que as pretensões de Vargas fossem alcançadas. Com a anunciada ameaça comunista, o tema da crise política instalou-se no cenário nacional, provocando novas 
articulações políticas. Vargas precisou, novamente, barganhar com os governos estaduais. O grupo político armandista, tendo como seu porta voz o jornal O Estado de S. Paulo, se viu diante da difícil escolha de apoiar Vargas no combate ao comunismo ou defender o respeito à ordem constitucional. $\mathrm{Na}$ ocasião, os armandistas optaram por combater o comunismo a todo custo, apoiando as medidas de cerceamento das liberdades, inclusive da liberdade de imprensa, promovidas pelo governo Vargas. Nesse sentido, liberalismo e conservadorismo autoritário coexistiram, paradoxalmente, no pensamento e ação do grupo armandista, explicitados principalmente na/pela posição adotada pelo jornal O ESP (PRADO; CAPELATO, 1989). Apoiar a aprovação da Lei de Segurança Nacional e do Estado de Guerra representou uma contradição nas posições liberais e republicanas defendidas pelo grupo. Tal atitude foi vista como ingenuidade política e erro de estratégia, limites que favoreceram os avanços de Vargas, que tomou as necessárias para criar condições para o golpe de Estado que estava sendo preparado.

Entretanto, destacamos que o tema da crise política, gerado pelo clima de alarde em torno da ameaça comunista, também foi usado como estratégia pelo grupo político armandista. Ao posicionar-se a favor das medidas para combater o avanço do comunismo e reforçar a ideia de uma crise política provavelmente mais inventada que real, aquele grupo usou o momento para divulgar seu projeto político como proposta alternativa e certeira para os rumos do país. Foi justamente em meio a esse clima que Armando de Salles Oliveira "jogou a toalha", descompatibilizandose do governo estadual e dando início à sua campanha eleitoral à presidência. Ao mesmo tempo, numa ação orquestrada, o jornal $O E S P$ passou a reforçar o compromisso do candidato Salles Oliveira com a defesa da Constituição. Duas outras preocupações perpassaram os discursos pronunciados por Salles Oliveira durante a campanha eleitoral: a de apresentar São Paulo como modelo de administração bem sucedida, depois da sua gestão como interventor e governador do Estado, que poderia ser estendida para esfera nacional, a de representar São Paulo como fiel ao pacto federativo, desfazendo assim a imagem de um candidato preocupado apenas com interesses regionais, mas igualmente com os interesses da nação. Na pesquisa feita com a imprensa sobre a campanha eleitoral, encontramos as duas preocupações bem ressaltadas. Armando de Salles Oliveira foi, então, 
assim apresentado como o único político capaz de conduzir o país em meio à crise política vivenciada, o dirigente melhor preparado para fazer "o Brasil continuar". Esse político teve o apoio de um importante veículo formador de opinião, o jornal $O$ Estado de S. Paulo. O grupo desse jornal teve atuação importante no jogo político nacional que resultou no golpe de 10 de novembro de 1937. O exercício de investigação sobre a atuação desse jornal na deflagração do golpe do Estado Novo foi possibilidade aberta para se conhecer o pensamento e a ação dos armandistas, traduzidos em um projeto político de dominação nacional sob a égide das elites políticas de São Paulo.

Como projeto político derrotado, a atuação do grupo político armandista que o sustentava acabou sendo reduzida pela historiografia aos limites da história regional. O golpe de novembro de 1937 foi, ao contrário, significado como "golpe silencioso", cujo sucesso se deu em razão da ausência de qualquer maior resistência por parte dos grupos políticos de oposição a Vargas. Apagou da memória social a existência e resistência das oposições, sobretudo do grupo armandista. Com o Estado Novo, os próceres deste grupo foram condenados ao exílio, de onde continuaram a luta política antivarguista, mas também puderam fazer um exercício crítico acerca de seus erros e acertos de sua atuação no jogo político nacional. Para uma melhor compreensão do que foram aqueles anos de luta, particularmente o período 1933-1945, enfocamos a atuação de um dos mais ferrenhos opositores do governo Vargas, o armandista Paulo Duarte.

Foi durante o exílio (1938-1945), ainda envolvido pelas ações políticas contra Vargas, que Paulo Duarte iniciou sua avaliação a respeito do comportamento de seu grupo, com o intuito de identificar onde erraram e porque foram derrotados. Ao construir suas memórias, a percepção que Duarte tinha da experiência de seu passado e de seu grupo sofreu algumas ressignificações. Nesse processo, o paulista já não reconhecia que seu grupo político, principalmente no que diz respeito a Salles Oliveira e Julio de Mesquita Filho, tivessem as características necessárias para enfrentar Vargas e derrubar a ditadura. Ao fazer essa avaliação, o sentimento de ressentimento ganha centralidade em sua narrativa. Ele se reconhece como injustiçado, pois entendia que havia dedicado sua vida a um projeto político, sendo porém o único que o defendia em toda e qualquer circunstancia, que estava inteiramente disposto a correr os riscos necessários. 
E ao buscar, via rememoração, destacar seu papel político junto ao grupo, Duarte exagerou na descrição da importância de suas ações no combate a Vargas e à ditadura do Estado Novo, principalmente aquelas praticadas durante o exílio. Nesse sentido, a escrita foi para Paulo Duarte uma tática de resistência ao esquecimento de sua relativa importante atuação política. Ele faz isso com cuidado, ancorando-se nos princípios de neutralidade e objetividade do testemunho, haja vista que relata igualmente os insucessos, equívocos, erros e frustrações dessa experiência política de seu grupo. Ao dar destaque para os insucessos, derrotas e frustrações, Duarte marcou sua narrativa pelo ressentimento tanto para com seu grupo político, que nunca the deu o merecido valor, como para com a ditadura varguista, que o via como "reles intrigante", embora o tenha exilado por duas vezes e o prendido inúmeras vezes. Nesse exercício de pisar e repisar os passos do grupo, com o intuito de perceber o que saiu errado em seus planos, remete-nos à reflexão de Peter Burke, para quem "os derrotados são incapazes de aceitar os acontecimentos e estão condenados a meditar sobre eles, a revivê-los e imaginar o quão diferentes poderiam ter sido" (1992, p. 246).

Aprisionado a esta condenação é como compreendemos o esforço de Paulo Duarte em constituir um arquivo e também um acervo memorialístico sobre si e seu grupo. Como derrotado, "incapaz de acertar os acontecimentos", ele busca revivelos, relatando a "verdadeira história" do período de 1933-1937, fundamentada em provas cabais, irrefutáveis: o arquivo e suas memórias, testemunho insuspeito dos acontecimentos vividos e presenciados. Nesse exercício de montagem de um suporte empírico, Duarte promove uma "autodocumentação" e uma "automonumentalização", nos recursos pensados por Moreschi (2012).

Entendemos que o propósito de Duarte era o de que os documentos recolhidos e por ele organizados não fossem apenas resíduos históricos, peças de uma história maior, mas sim a "verdadeira" história que deveria escrita a partir das "provas" depositadas em seu arquivo e suas memórias. Ao investigar a atuação dos armandistas e de Armando de Salles Oliveira no jogo político nacional dos anos 1933-1945, buscamos desnaturalizar um tipo de memória histórica que legitima e confere visibilidade apenas aos vencedores, impedindo a percepção dos vencidos, seus projetos, suas lutas. Assim, ao conferir visibilidade à perspectiva dos grupos derrotados, particularmente a voz de Paulo Duarte, esperamos ter contribuído para 
a renovação do debate historiográfico sobre o período 1933-1937 e sobre o grupo político armandista, em especial de sua memória. 


\section{REFERÊNCIAS BIBLIOGRÁFICAS}

AARÃO REIS, Daniel. Luís Carlos Prestes. Um revolucionário entre dois mundos. Companhia das Letras, 2014.

ABREU, Alzira Alves et al. (Coord.). Dicionário Histórico Biográfico Brasileiro pós 1930. 2. ed. Rio de Janeiro: Ed. FGV, 2001. Disponível em: <http://www.fgv.br/CPDOC/BUSCA/Busca/BuscaConsultar.aspx>.

ANSART, Pierre. História e memória dos ressentimentos. In BRESCIANI, $S$ \& NAXARA, M, Memória e (res)sentimento. Campinas: Ed. UNICAMP, 2004.

BERSTEIN, Serge. A cultura política. In: Para uma história cultural. Editorial estampa, 1998, Rio de Janeiro, RJ.

BOBBIO, Norberto; MATTEUCI, Nicolas; PASQUINO, Gianfranco. Dicionário de política. Vol. I, 11. Ed. Brasília: UNB, 1998.

BOMENY, Helena. Um poeta na política. Mário de Andrade, paixão e compromisso. Casa da palavra, 2012.

BORGES, Vavy Pacheco. Getúlio Vargas e a Oligarquia Paulista. História de uma esperança e muitos desenganos, 1979.

BORGES, Vavy Pacheco. Anos 1930 e política. História e Historiografia. In: FREITAS, Marcos César. Historiografia brasileira em perspectiva. São Paulo: Contexto, 1998.

BOSI, E. Memória e Sociedade: Lembranças de Velhos. 1a ed. São Paulo, Companhia das Letras, 1979.

CAMARGO, Aspásia. [et al]. O golpe silencioso. Rio de Janeiro. Ed. Rio Fundo, 1989.

CANDIDO, Antônio. Prefácio. In Memórias. E vai começar uma nova era. São Paulo: Hucitec, 1979, v. IX.

CAPELATO, Maria Helena; PRADO, Maria Lígica. O Bravo Matutino: imprensa e ideologia no jornal "O Estado de S. Paulo". São Paulo: Alfa-Omega, 1980.

CARDOSO, Irene de Arruda Ribeiro. A universidade da comunhão paulista. São Paulo. Autores Associados: Cortez, 1982.

CARONE, Edgar. Revoluções no Brasil contemporâneo (1922 - 1938). Ed. Ática: São Paulo, 1965.

CARONE, Edgar. A luta contra o Estado Novo. In Perspectiva. Ano 2, vol. 2 Araraquara: Unesp - 1977.

CARONE, Edgard. A Segunda República. São Paulo: DIFEL, 1974.

CASALECCHI, José E. O Partido Republicano Paulista: política e poder (18891926). São Paulo: Brasiliense, 1987.

CERTEAU, Michael. A Escrita da história/Michel de Certeau; tradução de Maria de Lourdes Menezes. - Rio de Janeiro: Forense Universitária, 1982. 
CODATO, Adriano. A elite destituída: a classe política paulista nos anos trinta. In: Caldeira, J. R. (Org.). História do Estado de São Paulo. São Paulo: Ed. Unesp, 2009.

COHEN, Ilka Stern. "Para onde vamos?" Alternativas políticas no Brasil (1930-1937). Tese de doutoramento. São Paulo: Universidade de São Paulo, 1997.

COHEN, Ilka Stern. Quando perder é vencer. In: Revista de História. 2012 Disponível

em:

http://www.revistadehistoria.com.br/secao/dossie-imigracao-italiana/quando-perder-e -vencer. Acesso em 16 fev. 2016.

DECCA, Edgar de. O silêncio dos vencidos. São Paulo: Ed. Brasiliense, 2004.

DELGADO, Lucilia de Almeida Neves. História oral: memória, tempo, indentidades. 2. ed. Belo Horizonte: Autêntica, 2010.

DUTRA, Eliana. História e culturas políticas. Definições, usos e genealogia. Varia história, n.28, dezembro de 2002.

FARIA, Daniel. Fronteiras do tempo: o discurso geracional e a mítica da juventude na identidade modernista. In Costa, Cléria Botêlho da; Ribeiro, Maria do Espírito Santo Rosa Cavalcante (org.). Fronteiras Móveis: culturas, identidades. - Goiânia: Ed. Da PUC Goiás, 2013, p. 105-127.

FAUSTO, Boris. O brilho do bronze - [Um diário]. Ed. Cosac Naify, 2014.

FERREIRA, Oliveiros S. Elos Partidos: uma nova visão do poder militar no Brasil. São Paulo: HARBRA, 2007.

FUNARI, Pedro Paulo. Paulo Duarte e o Instituto de Pré-História, Idéias, Campinas, v. 1, p. 155-179, 1994.

GOMES, Ângela de Castro. et al. Regionalismo e centralização política: partidos e constituinte nos anos 30. Rio de Janeiro: Nova Fronteira, 1980: p. 237-337.

GOMES, Â. M. C., LOBO, L.L. \& COELHO, RB.M. "Revolução e Restauração: a experiência paulista no período da constitucionalização". In GOMES (editor), 1996.

GOMES, Angela de Castro. "O 15 de novembro" In: GOMES, Ângela, PANDOLFI, Dulce e ALBERTI, Verena. (orgs). A República no Brasil. Rio de Janeiro, Nova Fronteira, 2002, p.13-29.

GOMES, Ângela de. História, historiografia e cultura política no Brasil: algumas reflexões. In: Culturas políticas: ensaios de história cultural, história política e ensino de história. Org. SOIHET, Raquel; BICALHO, Maria Fernanda B.; GOUVÊA, Maria de Fátima S. - Rio de Janeiro: Mauad, 2005.

GOMES, Ângela de Castro. Confronto e compromisso no processo de constitucionalização (1930-1935). In: O Brasil Republicano, v. 10: sociedade e política (1930-1964). GOMES, Ângela de Castro [et al]; $9^{\circ}$ ed. - Rio de Janeiro: Bertrand Brasil, 2007.

GOMES, Ângela de Castro; SCHMIDT, Benito. Apresentação. In Memórias e narrativas (auto)biográficas. Ângela de Castro Gomes e Benito Bisso Schmidt (orgs.). Rio de Janeiro: Editora FGV, 2009.

HAYASHI, Marli Guimarães. Paulo Duarte. Um Quixote brasileiro. Editora Hucitec. São Paulo, 2010. 
HAYAHSHI, Marli Guimarães. Adhemar de Barros no parlamento paulista. Revista Acervo Histórico, São Paulo, n. 4, p. 2-11, 2005.

HALBWACHS, Maurice. A memória coletiva. São Paulo: Centauro, 2004.

KOSELLECK, Reinhart. Futuro passado: contribuição à semântica dos tempos históricos. Rio de Janeiro: Contraponto: Ed. PUC - Rio, 2006.

LE GOFF, Jaqcues. História e memória. História e memória / Jacques Le Goff; tradução Bernardo Leitão... [et al.] -- Campinas, SP Editora da UNICAMP, 1990

LOWENTAHAL, David. Como conhecemos o passado. Projeto História - Revista de Estudos dos Pós-graduandos em História, do Departamento de História da Pontifícia Universidade Católica de São Paulo, São Paulo, v. 17, p. 63-201, 1998.

LORIGA, Sabina. A tarefa do historiador. In Memórias e narrativas (auto)biográficas. Angela de Castro Gomes e Benito Bisso Schmidt (orgs.). Rio de Janeiro: Editora FGV, 2009.

LOVE, Joseph L. A Locomotiva: São Paulo na federação brasileira (1889-1937). Rio de Janeiro: Paz e terra, 1982. .

MARTINS, Luciano. A revolução de 1930 e seu significado político. In. A Revolução de 1930. Seminário Internacional. Brasília: UnB,1983.

MORESCHI, Marcelo. Autodocumentação, arquivo e experiência: o Fundo Flávio de Carvalho/CEDAE. In: Revista Interfaces/número 17/ vol. 2/ julho-dezembro, 2012.

MORESCHI, Marcelo. 22 POR 42: O Paradigma da celebração. In: Remates de Males. Campinas - SP, (33. 1-2): pp. 255-271, Jan./Dez. 2013.

MOTTA, Rodrigo Patto Sá. Introdução à história dos partidos políticos brasileiros. $2^{\circ}$ edição revista. Belo Horizonte: Editota UFMG, 2008.

NICOLAU, Jairo. Eleições no Brasil. Do Império aos dias atuais. Rio de Janeiro: Zahar, 2012.

NETO, Lira. Getúlio. Do governo provisório à ditadura do Estado Novo. 1930-1945. São Paulo: Companhia das Letras, 2013.

OLIVEIRA, Fabiane Costa. Boris Fausto: História e Historiografia. O fazer-se de um historiador da República em interlocução com as Ciências Sociais. Tese de Doutorado. Universidade de Brasília, 2015.

PAIVA, Valéria. Almir de Andrade: intelectual do Estado Novo. In Revista História (São Paulo) v.34, n.1, p. 216-240, jan./jun. 2015. ISSN 1980-4369. Acesso em 29/03/2016.

PANDOLFI, Dulce (org.). Repensando o Estado Novo. Rio de Janeiro, Ed. FGV, 1999.

PANDOLFI, Dulce. "Voto e participação nas diversas repúblicas do Brasil". In GOMES, Angela; PANDOLFI, Dulce e ALBERTI, Verena (coords.). A República no Brasil. Rio de Janeiro, Nova Fronteira, 2002, p. 65-79.

PANDOLFI, Dulce. "Os anos 30: as incertezas do regime". In FERREIRA, Jorge e DELGADO, Lucília (orgs.). O Brasil Republicano. Rio de Janeiro, Civilização Brasileira, 2003, vol. 2, p. 13-37.

PINHEIRO, Letícia. Revista USP, São Paulo (26): p. 108-119, Junho/agosto 1995). 
PRADO, Maria Lígia Coelho. A democracia ilustrada: o Partido Democrático de São Paulo, 1926-1934. São Paulo: Ática, 1986.

RAMOS, Plínio de Abreu. Os partidos paulistas e o Estado Novo. Editora Vozes. Petrópolis, 1980.

RENTON, David. O marxismo dissidente de Victor Serge. Apresentação. In: O Ano I da Revolução Russa. SERGE, Victor. Boitempo editorial, 2007.

RICOEUR, Paul. O passado tinha um futuro. In: Morin, Edgar. A religação dos

saberes. O desafio do século XXI. Rio de Janeiro: Bertrand Brasil, 2001.

RICOEUR, Paul. A memória, a História, o Esquecimento. Campinas, SP: Editora da Unicamp, 2007.

SALGADO, Manoel Luiz. Escrever a história, domesticar o passado. In: Lopes, Antonio H. História e Linguagens. Rio de Janeiro: 7 letras, 2006, P. 45-58.

SALOMON, Marlon. A danação do arquivo: ensaio sobre a história e as artes das políticas culturais. SALOMON, Marlon. (org.). Goiânia-GO: Edições Riochete, 2011.

SALOMONI, Antonella. Um saber histórico de Estado: os arquivos soviéticos. In Saber dos arquivos. SALOMON, Marlon. (org.). Goiânia-GO: Edições Riochete, 2011.

SARLO, B. Tempo passado: cultura da memória e guinada subjetiva. São Paulo: Companhia das Letras; Belo Horizonte: UFMG, 2007.

STEFFENS, Marcelo H., Getúlio Vargas biografado. Análise de biografias publicadas entre 1939 -1988. Tese de doutorado. Belo Horizonte, 2008.

SANDES, Noé Freire. A memória inconsútil. São Paulo, 1932. In: FREDRIGO, Fabiana de Souza; OLIVEIRA, Fabiane Costa; SALOMON, Marlon. (Org.). Escritas da história: arte, cultura e memória. Goiânia: UCG, 2009. (v. 1). p. 179-197.

SAMPAIO, Maria Ruth Amaral. São Paulo 1934-1938 - Os anos da administração de Fábio Prado. São Paulo: FAUUSP,1999.

SANDES, Noé Freire. Memória, arquivo e ressentimento: as memórias de Paulo Duarte. Revista IHGB, 2011.

SANDES, Noé Freire. O jornalista Costa Rego e o tempo revolucionário (1930). Revista Brasileira de História, v. 28, p. 41-61, 2008.

SANDES, Noé Freire. O tempo revolucionário e outros tempos: o jornalista Costa Rego e a representação do passado (1930-1937). Goiânia, Editora UFG: 2012.

SILVA, Antônio Carlos Pacheco e. Armando de Salles Oliveira. - São Paulo: Parma: Edusp, 1980.

SILVA, Paulo Thiago Santos Gonçalves da. A Associação Nacional dos Professores Universitários de História: espaço de identificação profissional e legitimação do saber histórico (1961-1977). 2014. 333 f. Tese (Doutorado em História) Universidade de Brasília, Brasília, 2014.

SILVA, Thiago e SILVA, Estevão. Eleições no Brasil antes da democracia : o Código Eleitoral de 1932 e os pleitos de 1933 e 1934. In: Rev. Sociol. Polit., v. 23, n. 56, p. 75-106, dez. 2015. 
SIRINELLI, Jean-François. Os intelectuais. In: Por uma história política. [Direção de] René Remond. Rio de Janeiro. Ed. FGV, 2003.

SOUSA, Carolina Soares. Política: a arte de lembrar e de esquecer. Os projetos políticos paulistas (1933-1934). Dissertação de mestrado. UnB, 2012.

SOUSA, Carolina Soares. "Para que o Brasil continue". Armando de Salles Oliveira e a comunidade política do jornal O Estado de S. Paulo: entre a memória e a história (1933-1945). Anais eletrônicos do XXVII Simpósio Nacional de História. Anpuh, 2013.

SOUSA, Maria do Carmo Carvalho Campello de. Estados e partidos políticos no Brasil (1930-1964). São Paulo, Alfa-Omega, 1976.

SOUZA, Mayara P. O que não devia ser esquecido: $A$ anistia e os usos do passado na Constituinte de 1946. Dissertação de mestrado, 2010.

SUGIMOTO, Luís. A saga de Paulo Duarte, combativo e combatido, nas 60 mil peças de seu acervo na Unicamp. In Jornal da Unicamp, Edição 209, 7 a 21 de abril de 2003. Acesso em 05 de setembro de 2015.

VEYNE, Paul. Como se escreve a história. $4^{\circ}$ ed. Brasília. Editora Universidade de Brasília, 2014.

VESENTINI, Carlos Alberto. A teia do fato (uma proposta de estudo sobre a memória histórica). São Paulo: Ed. Hucitec, História Social, USP, 1997.

VICTOR, Rogério Lustosa. O labirinto integralista: o PRP e o conflito de memórias. Tese de Doutorado. Goiânia: Universidade Federal de Goiás, 2012.

VICTOR, Rogério Lustosa. O integralismo nas águas do Lete. Dissertação de mestrado, 2005, UFG.

VILLA, Marco Antônio. A revolução de 1932: constituição e cidadania. Ed. Imprensa oficial do Estado de São Paulo. São Paulo, 2010.

ZIOLI, Miguel. Paulo Duarte (1899-1984). Um intelectual nas trincheiras da memória. Doutorado em História, Unesp/Assis, SP, 2010.

ZUCKERMAN, Alan. Elite política: lições de Mosca e Pareto. In: BOTTOMORE, T. B. et. al. Elites políticas. Brasília: UNB, 1978.

\section{FONTES}

\section{Jornais}

O ESP, 17/11/1933.

O ESP, 10/07/1934.

O ESP, 28/02/1934.

O ESP, 30/12/1936.

O ESP, 08/04/1937.

OESP, 10/04/1937. 
OESP, 16/04/1937.

O ESP, 13/04/1937.

O ESP 22/07/1937.

O ESP, 01/09/1937.

O ESP 01/04/1937.

O ESP, 02/04/1937.

O ESP, 03/03/1937.

O ESP, 03/04/1937.

O ESP, $18 / 04 / 1937$.

O ESP, 22/04/1937.

O ESP 18/04/1937.

O ESP, 03/03/1937.

O ESP, 03/04/1937.

O ESP, 03/04/1937.

O ESP, 07/04/1937.

O ESP, 01/06/1937.

O ESP 14/04/1937.

O ESP, 01/06/1937.

O ESP, 01/06/1937.

O ESP, 04/06/19.

O ESP, 11/06/1937.

O ESP, 04/07/1937.

O ESP, 08/08/1937.

O ESP, 07/10/1937

O ESP, 02/10/1937.

Correio da Manhã, 01/12/1933.

Correio da Manhã, 12/01/1934.

\section{Livros}

COARACY, Vivaldo. Encontros com a vida. Ed. José Olympio. Rio de Janeiro: 1962.

OLIVEIRA, Armando de Salles. Escritos Políticos. São Paulo: Arx, 2002.

OLIVEIRA, Armando de Salles. Jornada Democrática. (Discursos Políticos). Livraria José Olympio Editora. Rio de Janeiro, 1937. 
OLIVEIRA, Armando de Salles Oliveira. Diagrama de uma situação política. Manifestos políticos do exílio. Editora Renascença S.A. São Paulo, 1945.

VARGAS, Getúlio. Diários. (1930-1942). São Paulo: Siciliano; Rio de Janeiro: Fundação Getúlio. Vargas, 1995. 2 v.

\section{Obras memorialísticas de Paulo Duarte:}

DUARTE, Paulo. Memórias. Raízes Profundas. São Paulo: Hucitec, 1974. v. I, 257 p. . Memórias. Inteligência da Fome. São Paulo: Hucitec,1975, v. II, 328 p. . Memórias. Selva oscura. São Paulo: Hucitec, 1976, v. III, 389 p. . Memórias. Os mortos de Seabrook. São Paulo: Hucitec, 1976, v. IV, 436 p. . Memórias. Apagada e vil mediocridade. São Paulo: Hucitec, 1976, v. V, 356

p. . Memórias. Ofício de trevas. São Paulo: Hucitec, 1977, v. VI, 321 p. . Memórias. Miséria universal, miséria nacional e minha própria miséria. São Paulo: Hucitec, 1978, v. VII, 331 p. VIII, $339 \mathrm{p}$. Memórias. Vou-me embora pra passárgada. São Paulo: Hucitec, 1978, v.

$\overline{323}$. Memórias. E vai começar uma nova era. São Paulo: Hucitec, 1979, v. IX, 